Prepared in cooperation with Pierce County Public Works and Utilities, Surface Water Management; and King County Department of Natural Resources and Parks, Water and Land Resources Division

\title{
Geomorphic Analysis of the River Response to Sedimentation Downstream of Mount Rainier, Washington
}

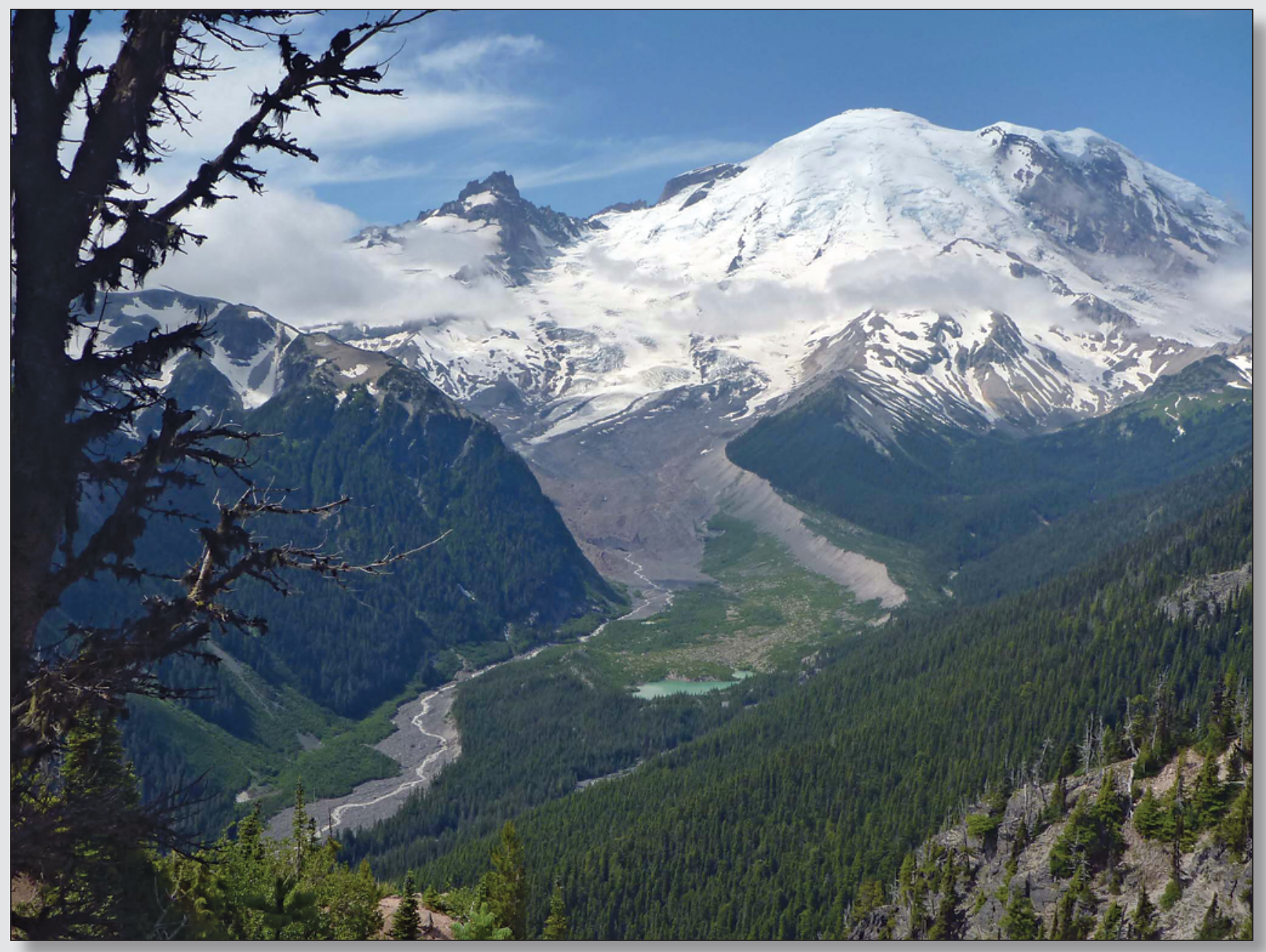

Open-File Report 2012-1242 
Cover: Photograph taken from Emmons Vista in Mount Rainier National Park, Washington, showing view of Mount Rainier, Emmons Glacier, and the headwaters of the White River. (Photograph taken by C.S. Magirl, U.S. Geological Survey, August 14, 2011.) 


\section{Geomorphic Analysis of the River Response to Sedimentation Downstream of Mount Rainier, Washington}

By Jonathan A. Czuba, Christopher S. Magirl, Christiana R. Czuba, Christopher A. Curran, Kenneth H. Johnson, Theresa D. Olsen, Halley K. Kimball, and Casey C. Gish

Prepared in cooperation with Pierce County Public Works and Utilities, Surface Water Management; and King County Department of Natural Resources and Parks, Water and Land Resources Division

Open-File Report 2012-1242

U.S. Department of the Interior

U.S. Geological Survey 


\section{U.S. Department of the Interior \\ KEN SALAZAR, Secretary}

\section{U.S. Geological Survey \\ Marcia K. McNutt, Director}

U.S. Geological Survey, Reston, Virginia: 2012

For more information on the USGS-the Federal source for science about the Earth,

its natural and living resources, natural hazards, and the environment-visit

http://www.usgs.gov or call 1-888-ASK-USGS

For an overview of USGS information products, including maps, imagery, and publications, visit $h$ ttp://www.usgs.gov/pubprod

To order this and other USGS information products, visit http://store.usgs.gov

Suggested citation:

Czuba, J.A., Magirl, C.S., Czuba, C.R., Curran, C.A., Johnson, K.H., Olsen, T.D., Kimball, H.K., and Gish, C.C., 2012, Geomorphic analysis of the river response to sedimentation downstream of Mount Rainier, Washington: U.S.

Geological Survey Open-File Report 2012-1242, 134 p.

Any use of trade, product, or firm names is for descriptive purposes only and does not imply endorsement by the U.S. Government.

Although this report is in the public domain, permission must be secured from the individual copyright owners to reproduce any copyrighted material contained within this report. 


\section{Contents}

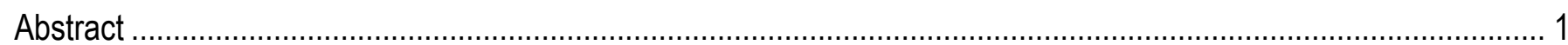

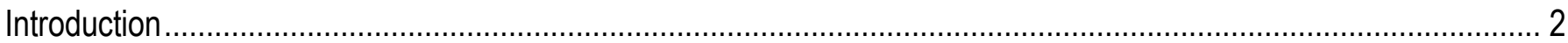

Purpose and Scope ………………………………

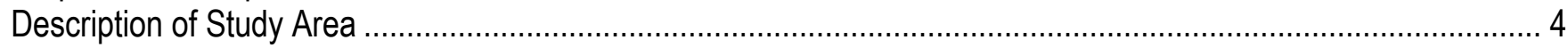

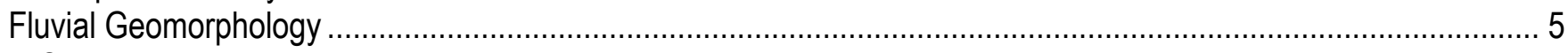

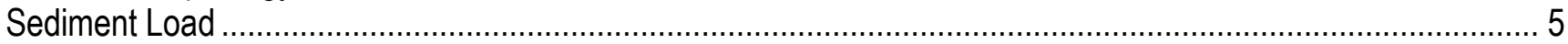

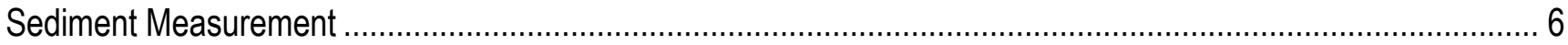

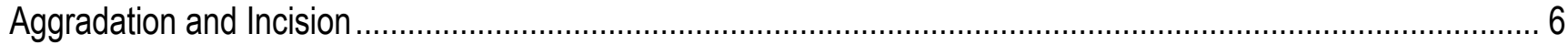

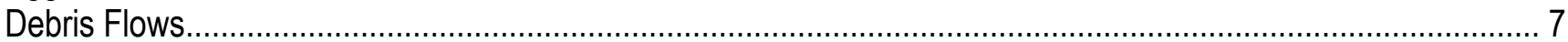

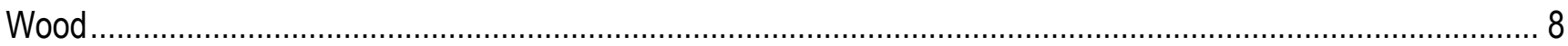

Conceptual Model of Sediment Delivery from Mount Rainier ……...................................................................... 9

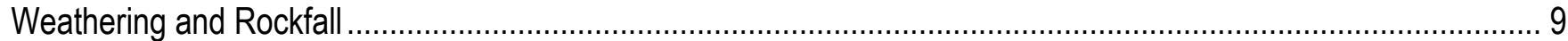

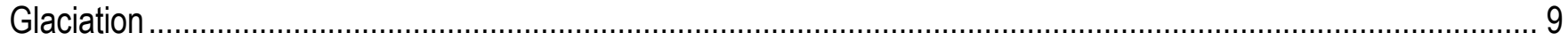

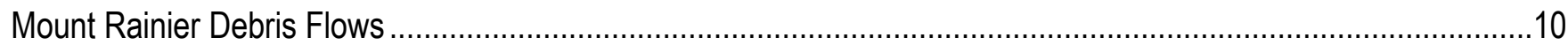

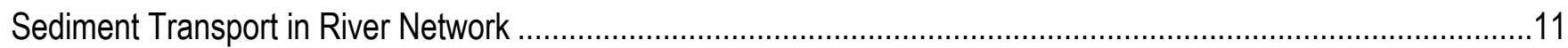

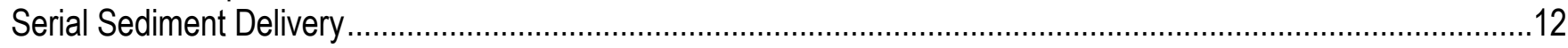

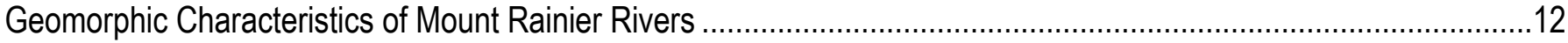

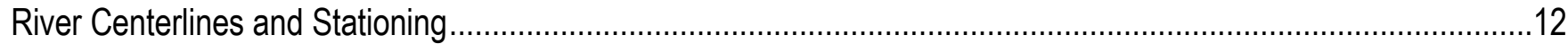

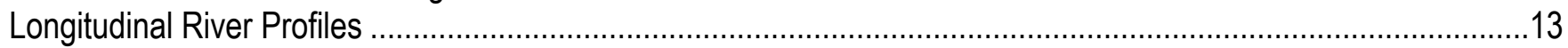

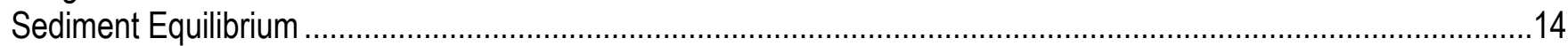

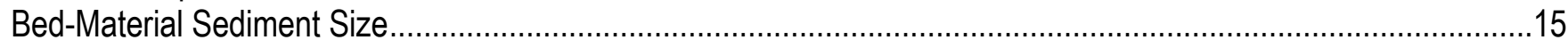

Hydrologic Trends and Geomorphic Response at Gaging Stations................................................................16

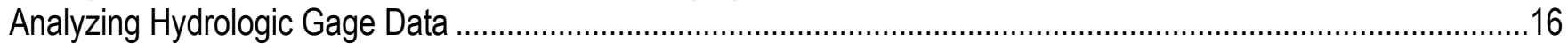

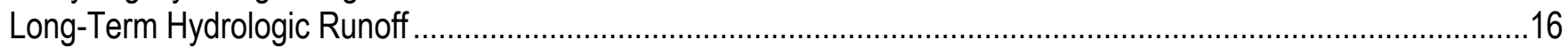

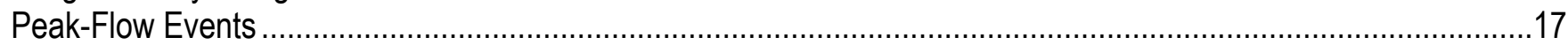

Implications of 20th-Century Hydrology on Sediment Production and Transport ...............................................18

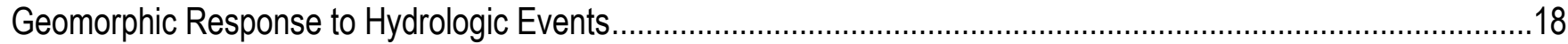

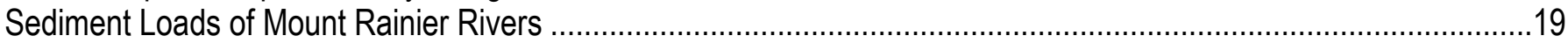

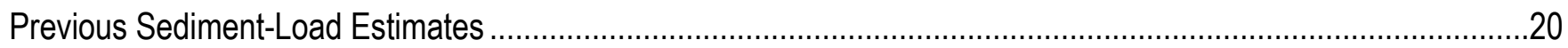

Historical Changes in Plan Form and Profiles in Mountainous River Reaches ..................................................22

Change in Active-Channel Width for Rivers Draining Mount Rainier ............................................................22

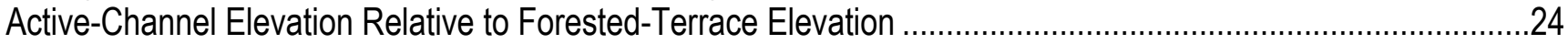

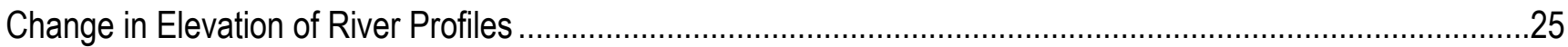

Sediment Contributions from the Flood Plain due to Expansion of the Active Channel......................................25

The Link between Superglacial Debris and Downstream Aggradation ..........................................................26

The Link between the 1963 Debris Avalanche and Upper White River Aggradation ..........................................27

Sediment Supply from Cascade Uplands outside Mount Rainier National Park ....................................................27

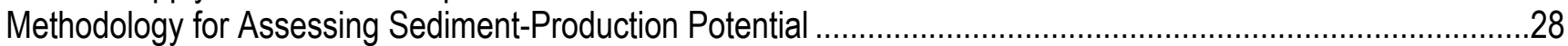

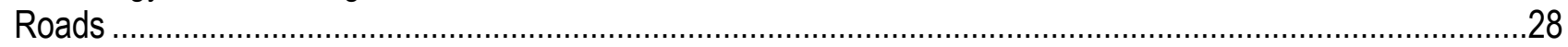

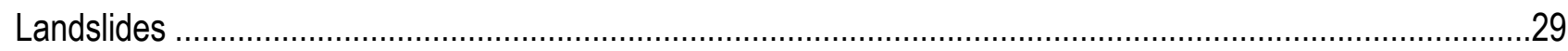

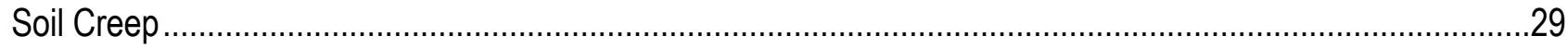

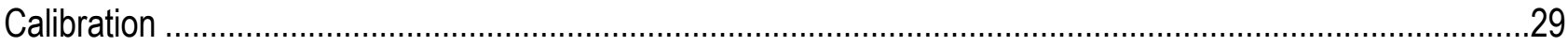

Sediment-Production Potential Results ............................................................................................... 
Sediment Loads of Mount Rainer Rivers-Continued

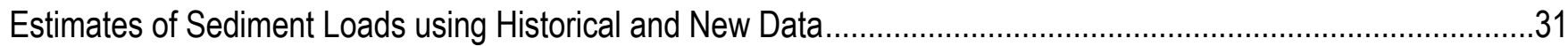

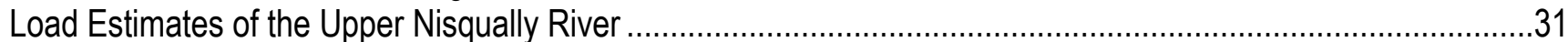

Seasonality in Suspended-Sediment Concentration in Mount Rainier Rivers ...................................................32

Suspended-Sediment Load of the Puyallup River from 1978 to 1994 ............................................................32

Sediment-Load Estimates of the White River from Recent Measurements ......................................................33

Collection of Sediment Data and Calculation of Sediment Loads ...............................................................33

Suspended-Sediment Load and Bedload of the White River .....................................................................34

Estimated Bedload-Transport relation for the White, Puyallup, and Carbon Rivers............................................35

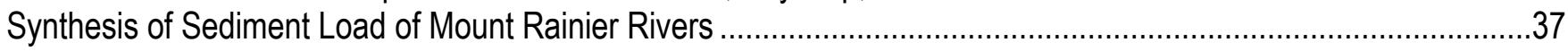

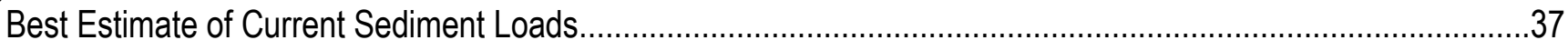

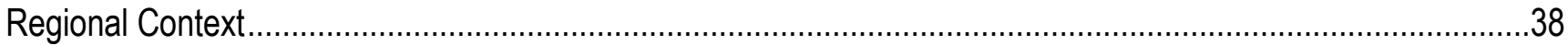

Relative Sediment Contributions from Mount Rainier and Other Sources ......................................................39

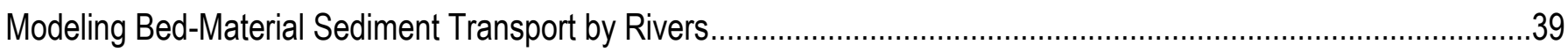

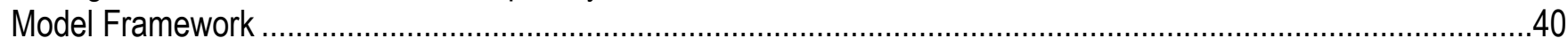

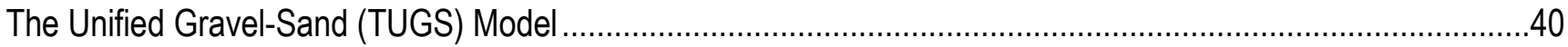

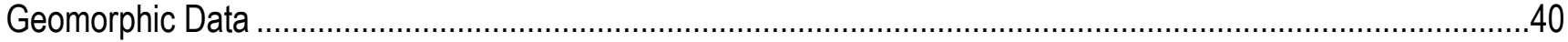

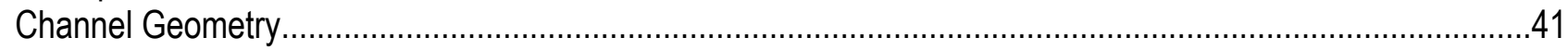

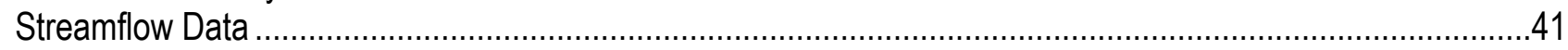

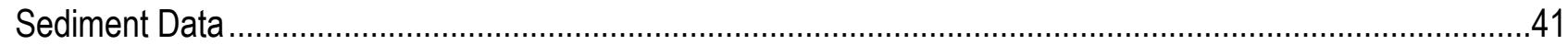

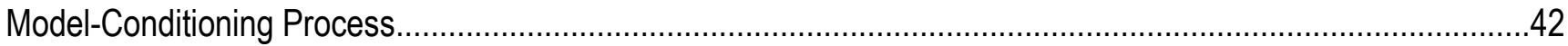

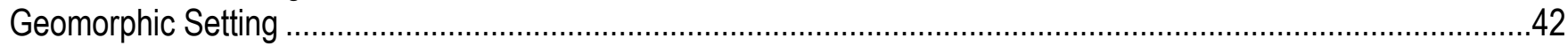

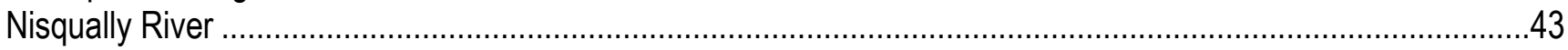

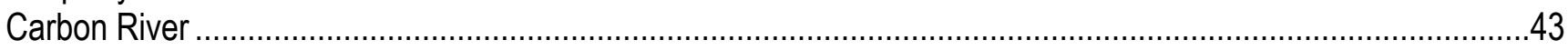

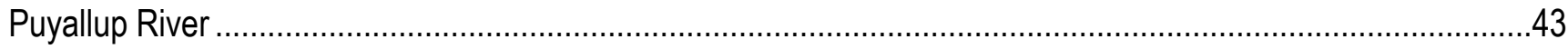

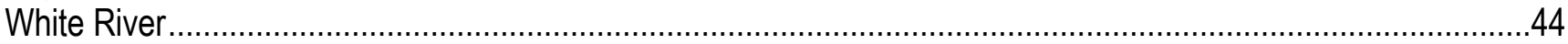

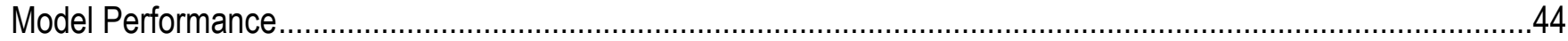

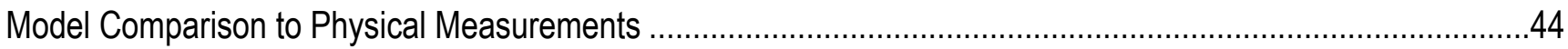

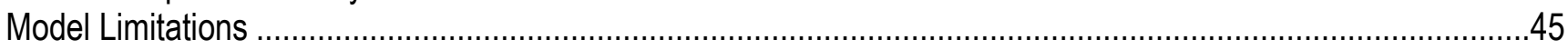

Model Simulations of the Nisqually, Carbon, Puyallup, and White Rivers .......................................................46

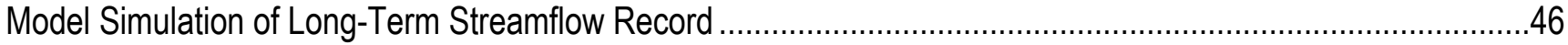

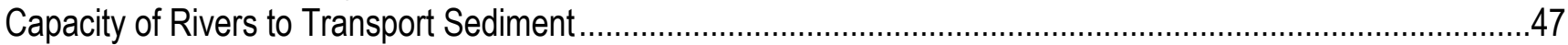

Spatial and Temporal Geomorphic Change due to Altered Sediment Supply ...............................................48

Potential Effect of Changing Hydrologic Conditions on Future Bed Elevations .............................................50

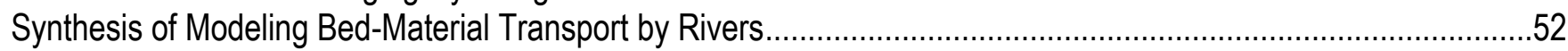

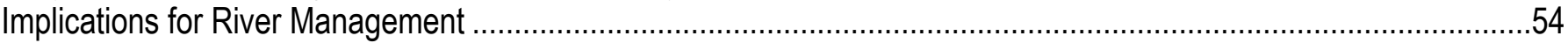

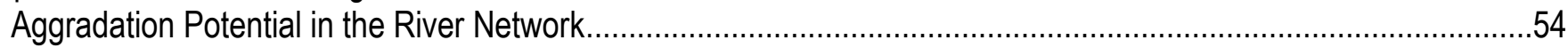

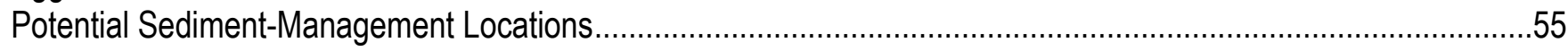

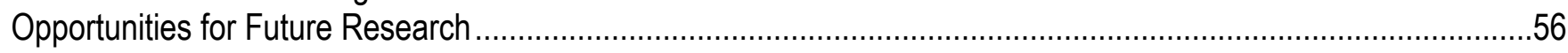

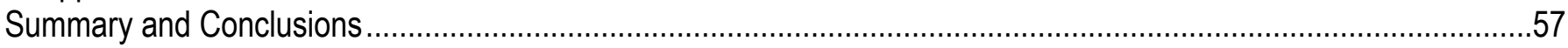

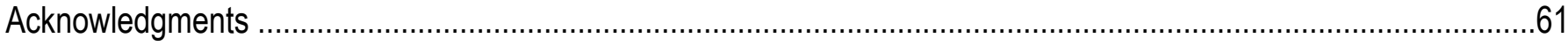

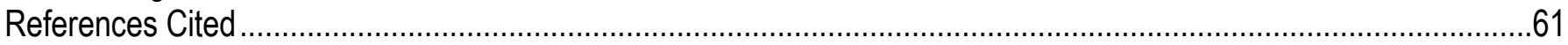

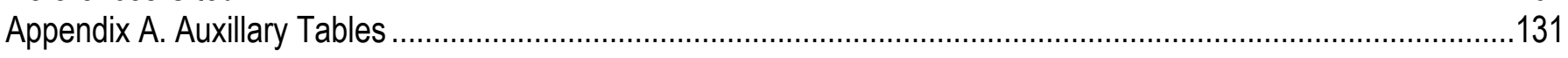




\section{Figures}

Figure 1. Map showing rivers, basin boundaries, U.S. Geological Survey streamflow-gaging stations, and tributaries draining Mount Rainier, Washington, along with river stationing used in the this study ........................................ 73

Figure 2. Conceptual model of processes affecting sediment delivery from Mount Rainier, Washingto. .................. 74 Figure 3. Images of the headwaters of the White River at the terminus of the Emmons Glacier, Mount Rainier,

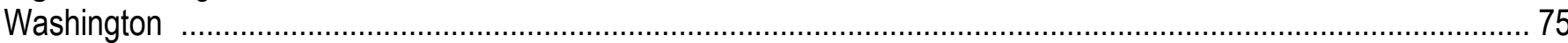

Figure 4. Graph showing river elevation profiles for main-stem rivers and tributaries of the (A) Puyallup, (B) White, (C) Carbon, (D) Nisqually, and (E) Cowlitz Rivers, Washington...................................................... 76

Figure 5. Graph showing bed-material size gradations of the Puyallup, Carbon, White, and upper Nisqually Rivers, Washington

Figure 6. Maps showing bed-material size gradations of the Nisqually, Carbon, Puyallup, and White Rivers, Washington

Figure 7. Graphs showing (A) Hydrologic conditions during the 20th century in the Mount Rainier, Washington, catchment as reflected in 10-year moving-average daily-discharge values, normalized by the mean annual flow, for U.S. Geological Survey streamflow-gaging stations Puyallup River at Puyallup (12101500) and the Cowlitz River at Packwood (14226500); and (B) 10-year moving average of sea surface temperatures in the northern Pacific Ocean as reflected with the Pacific Decadal Index

Figure 8. Graph showing annual peak flows for U.S. Geological Survey streamflow-gaging stations on unregulated section of the main-stem rivers draining Mount Rainier, Washington: $(A)$ the Puyallup River near Orting gage (12093500), (B) the Carbon River near Fairfax gage (12094000), (C) the Cowlitz River at Packwood gage (14226500), and (D) the Nisqually River near National gage (12082500)

Figure 9. Graph showing stage for median flow and daily discharge as measured at the U.S. Geological Survey streamflow-gaging station Nisqually River near National (12082500).

Figure 10. Map showing active-channel width in 2009 of rivers draining Mount Rainier, Washington.

Figure 11. Graph showing active-channel width from 1965, 1994, and 2009 of rivers draining Mount Rainier, Washington

Figure 12. Map showing change in active-channel width from 1965 to 1994 for rivers draining Mount Rainier, Washington

Figure 13. Map showing change in active-channel width from 1994 to 2009 for rivers draining Mount Rainier, Washington

Figure 14. Graph showing the difference in elevation between the forested terrace adjacent to the active channel and the active channel for the (A) Carbon River, (B) Nisqually River, (C) Puyallup River, and (D) White River, Washington

Figure 15. Graph showing active-channel width of rivers draining Mount Rainier, Washington, in 2009 versus

(A) total glacier retreat from 1913 to 1994 of river's primary glacier source and (B) percentage of mantling of superglacial debris on river primary glacier source. All glacier data by Nylen (2004).

Figure 16. Map showing location of 27 subcatchments analyzed to calculate sediment-production potential and the three additional subcatchments used for calibration

Figure 17. Graph showing relation between the predictions of sediment-production potential from five calibration subcatchments and the measured total sediment load. Error bars represent uncertainty in the sediment-load predictions

Figure 18. Map showing predicted sediment-production yield from roads, landslides, and soil creep for mountainous subcatchments outside Mount Rainier National Park that contribute to the Puyallup, Carbon, and White Rivers and the upper Nisqually River 
Figure 19. Graph showing suspended-sediment concentration versus discharge as collected in 1974-1976 by Nelson (1978) at U.S. Geological Survey streamflow-gaging station White River below Clearwater River

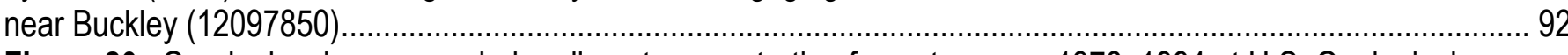

Figure 20. Graph showing suspended-sediment concentration for water years 1978-1994 at U.S. Geological Survey streamflow-gaging station Puyallup River at Puyallup (12101500) ....................................................... 92

Figure 21. Graph showing annual suspended-sediment load and daily streamflow at U.S. Geological Survey streamflow-gaging station Puyallup River at Puyallup (12101500)....................................................................9. 93

Figure 22. Graph showing regression equations used to estimate suspended-sediment concentration and fine suspended-sediment concentration from turbidity at U.S. Geological Survey streamflow-gaging station White River at

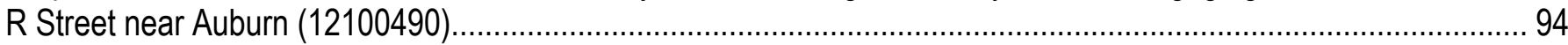

Figure 23. Graph showing regression equation used to estimate bedload from streamflow at U.S. Geological Survey streamflow-gaging station White River at R Street near Auburn (12100490)............................ 94 Figure 24. Graph showing time series of streamflow and suspended-sediment concentration at U.S. Geological Survey streamflow-gaging station White River at R Street near Auburn (12100490) 95

Figure 25. Graph showing time series of streamflow, cumulative suspended-sediment load, cumulative fine suspended-sediment load, and cumulative bedload for water year 2011 at U.S. Geological Survey streamflow-gaging station White River at R Street near Auburn (12100490) 95

Figure 26. Graph showing suspended-sediment loads for 3-month periods at the U.S. Geological Survey streamflow-gaging station White River at R Street near Auburn (12100490) Figure 27. Graph showing bedload measurements from 1986 and 2010-2011 at U.S. Geological Survey streamflowgaging stations Carbon River near Orting (12094300, referred to as Carbon River at Crocker by Sikonia, 1990), Puyallup River near Orting (12093500), and White River at R Street near Auburn (12100490) .............................96 Figure 28. Graph showing estimated annual bedload for water years 1984-2011 at U.S. Geological Survey streamflow-gaging stations Carbon River near Orting (12094300, referred to as the Carbon River at Crocker by Sikonia, 1990), Puyallup River near Orting (12093500), and White River at R Street near Auburn (12100490) .........97 Figure 29. Graph showing sediment load values of the Nisqually River flowing into Alder Lake and the lower Puyallup River compared to sediment-load data reported from other rivers throughout the Pacific Northwest........... 98 Figure 30. Graph showing geomorphic variables of the Nisqually River: (A) slope, (B) measured active-channel width, (C) D90 and D50 size of bed-surface sediment, and (D) percent sand of bed-surface sediment. Error bars represent one standard deviation of the particle-size distribution

Figure 31. Graph showing geomorphic variables of the Carbon River: (A) slope, (B) measured active-channel width, (C) D90 and D50 size of bed-surface sediment, and (D) percent sand of bed-surface sediment .......................... 100 Figure 32. Graph showing geomorphic variables of the Puyallup River: (A) slope, (B) measured active-channel width, (C) D90 and D50 size of bed-surface sediment, and (D) percent sand of bed-surface sediment 101

Figure 33. Graph showing geomorphic variables of the White River: $(A)$ slope, $(B)$ measured active-channel width, (C) D90 and D50 size of bed-surface sediment, and (D) percent sand of bed-surface sediment. 102

Figure 34. Graph showing comparison of simulated daily sediment loads to measured sediment loads for the Carbon River at State Route 162/Pioneer Way, Puyallup River at Calistoga Street, and White River at R Street.... 103 Figure 35. Graph showing daily streamflow and simulated annual bed-material sediment loads for the (A) Nisqually River at State Route 7, (B) Carbon River at State Route 162/Pioneer Way, (C) Puyallup River at Calistoga Street, and (D) White River at R Street.

Figure 36. Graph showing capacity of the Nisqually River to transport sediment: (A) bed-material sediment-transport capacity (after model conditioning) and stream power and (B) unit bed-material sediment-transport capacity (after model conditioning) and unit stream power .....

Figure 37. Graph showing capacity of the Carbon River to transport sediment: (A) bed-material sediment-transport capacity (after model conditioning) and stream power and (B) unit bed-material sediment-transport capacity (after model conditioning) and unit stream power 
Figure 38. Graph showing capacity of the Puyallup River to transport sediment: (A) bed-material sediment-transport capacity (after model conditioning) and stream power and (B) unit bed-material sediment-transport capacity (after model conditioning) and unit stream power

Figure 39. Graph showing capacity of the White River to transport sediment: (A) bed-material sediment-transport capacity (after model conditioning) and stream power and (B) unit bed-material sediment-transport capacity (after model conditioning) and unit stream power

Figure 40. Graph showing effect of pulse grain size, pulse volume, and streamflow on the characteristic transport time (A1-D1), sediment load (A2-D2), and bed volume (A3-D3) for the Nisqually (A1-A3), Carbon (B1-B3), Puyallup (C1-C3), and White Rivers (D1-D3).....

Figure 41. Graph showing characteristic transport time for sediment pulses to arrive downstream for different pulse grain size, pulse volume, and streamflow for the (A) Nisqually, (B) Carbon, (C) Puyallup, and (D) White Rivers...... 108 Figure 42. Graph showing Nisqually River response to sediment pulse input for $(A)$ characteristic residence time for D50 sediment to move through each 400-m node and (B) the maximum increase in bed volume as a percentage of input pulse volume

Figure 43. Graph showing Carbon River response to sediment pulse input for $(A)$ characteristic residence time for D50 sediment to move through each 400-m node and (B) the maximum increase in bed volume as a percentage of input pulse volume....

Figure 44. Graph showing Puyallup River response to sediment pulse input for (A) characteristic residence time for D50 sediment to move through each 400-m node and (B) the maximum increase in bed volume as a percentage of input pulse volume.

Figure 45. Graph showing White River response to sediment pulse input for $(A)$ characteristic residence time for D50 sediment to move through each 400-m node and (B) the maximum increase in bed volume as a percentage of input pulse volume

Figure 46. Graph showing potential future bed-elevation change for the Nisqually River after 25 years for $(A)$ a baseline condition and $(B)$ a future condition; and after 50 years for $(C)$ a baseline condition and (D) a future condition

Figure 47. Graph showing potential future bed-elevation change for the Carbon River after 25 years for (A) a baseline condition and $(B)$ a future condition; and after 50 years for $(C)$ a baseline condition and $(D)$ a future condition

Figure 48. Graph showing potential future bed-elevation change for the Puyallup River after 25 years for $(A)$ a baseline condition and $(B)$ a future condition; and after 50 years for $(C)$ a baseline condition and (D) a future condition

Figure 49. Graph showing potential future bed-elevation change for the White River after 25 years for (A) a baseline condition and $(B)$ a future condition; and after 50 years for $(C)$ a baseline condition and $(D)$ a future condition

Figure 50. Graph showing lower White River, Washington, $(A)$ approximate bed elevations from measurements (raw model input) and from steady state simulations (after model conditioning) and (B) change in elevation after the model-conditioning process with quasi-equilibrium conditions.

Figure 51. Map of Mount Rainier, Washington, showing where potential sediment-management actions would be most effective based on geomorphic conditions that suggest sediment accumulates naturally, including both longand mid-term transient-storage reaches. Also shown are best estimates for long-term sediment-load values for rivers in the study 


\section{Tables}

Table 1. U.S. Geological Survey streamflow-gaging stations in the State of Washington used for hydrologic and geomorphic analysis in this study.

Table 2. Twenty largest peak-flow events at the U.S. Geological Survey streamflow-gaging station Nisqually River near National (12082500) between 1989 and 2009 and the resulting change in stage, for median flow, at the gage after to peak-flow event.

Table 3. Sample of 81 meteorological, hydrologic, and atmospheric parameters collected and correlated to the change in stage for the 20 largest peak-flow events measured at the Nisqually River gage.

Table 4. Published sediment-load estimates for rivers in the Mount Rainier National Park, Washington, watershed and for the Pacific Northwest.

Table 5. Summary of active-channel width measured in 1965, 1994, and 2009 and the change in width between dates, for rivers draining Mount Rainier, Washington.

Table 6. Estimated sediment load contribution to river main stems due to increases in active-channel width, for rivers draining Mount Rainier, Washington, 1965-2009.

Table 7. Summary of sediment-production potential for Cascade Range subcatchments outside Mount Rainier National Park, Washington.

Table 8. Sediment load calculations and measurements completed as part of this study, for rivers draining Mount

Rainier, Washington.

Table 9. Scaling factors and U.S. Geological Survey streamflow-gaging stations used in developing long-term streamflow records for model simulations for the Nisqually, Carbon, Puyallup, and White Rivers, Washington

Table 10. Comparison of simulated sediment load into Alder Lake by the Nisqually River to measured sediment volumes of the delta of the Nisqually River in Alder Lake, Washington, from Czuba and others (2012).

Table 11. Simulated bed-material sediment loads for the Nisqually River at State Route 7, Carbon River at State Route 162/Pioneer Way, Puyallup River at Calistoga Street, and White River at R Street, Washington. Streamflow at the White River at $R$ Street is controlled by Mud Mountain Dam. 


\section{Conversion Factors, Datums, and Abbreviations and Acronyms}

\section{Conversion Factors}

Inch/Pound to SI

\begin{tabular}{lll}
\hline & \multicolumn{1}{c}{ Multiply } & \multicolumn{1}{c}{ To obtain } \\
\hline inch (in.) & Length & \\
inch (in.) & 2.54 & centimeter $(\mathrm{cm})$ \\
foot (ft) & 25.4 & millimeter $(\mathrm{mm})$ \\
mile (mi) & 0.3048 & meter $(\mathrm{m})$ \\
\hline & 1.609 & kilometer $(\mathrm{km})$ \\
\hline cubic foot per second $\left(\mathrm{ft}^{3} / \mathrm{s}\right)$ & Flow rate & \\
\hline
\end{tabular}

SI to Inch/Pound

\begin{tabular}{|c|c|c|}
\hline Multiply & By & To obtain \\
\hline \multicolumn{3}{|c|}{ Length } \\
\hline centimeter $(\mathrm{cm})$ & 0.3937 & inch (in.) \\
\hline millimeter (mm) & 0.03937 & inch (in.) \\
\hline meter $(\mathrm{m})$ & 3.281 & foot $(\mathrm{ft})$ \\
\hline kilometer $(\mathrm{km})$ & 0.6214 & mile (mi) \\
\hline \multicolumn{3}{|c|}{ Area } \\
\hline square meter $\left(\mathrm{m}^{2}\right)$ & 10.76 & square foot $\left(\mathrm{ft}^{2}\right)$ \\
\hline square kilometer $\left(\mathrm{km}^{2}\right)$ & 0.3861 & square mile $\left(\mathrm{mi}^{2}\right)$ \\
\hline \multicolumn{3}{|c|}{ Volume } \\
\hline cubic meter $\left(\mathrm{m}^{3}\right)$ & 35.31 & cubic foot $\left(\mathrm{ft}^{3}\right)$ \\
\hline cubic meter $\left(\mathrm{m}^{3}\right)$ & 1.308 & cubic yard $\left(\mathrm{yd}^{3}\right)$ \\
\hline \multicolumn{3}{|c|}{ Flow rate } \\
\hline cubic meter per second $\left(\mathrm{m}^{3} / \mathrm{s}\right)$ & 35.31 & cubic foot per second $\left(\mathrm{ft}^{3} / \mathrm{s}\right)$ \\
\hline cubic meter per day $\left(\mathrm{m}^{3} / \mathrm{d}\right)$ & 35.31 & cubic foot per day $\left(\mathrm{ft}^{3} / \mathrm{d}\right)$ \\
\hline cubic meter per year $\left(\mathrm{m}^{3} / \mathrm{yr}\right)$ & 35.31 & cubic foot per year $\left(\mathrm{ft}^{3} / \mathrm{yr}\right)$ \\
\hline $\begin{array}{l}\text { cubic meter per second per meter } \\
{\left[\left(\mathrm{m}^{3} / \mathrm{s}\right) / \mathrm{m}\right]}\end{array}$ & 10.76 & $\begin{array}{l}\text { cubic foot per second per foot } \\
{\left[\left(\mathrm{ft}^{3} / \mathrm{s}\right) / \mathrm{ft}\right]}\end{array}$ \\
\hline \multicolumn{3}{|c|}{ Power } \\
\hline watts (W) & 3.4121 & British thermal unit per hour $(B t u / h)$ \\
\hline watts per meter $(\mathrm{W} / \mathrm{m})$ & 1.04 & $\begin{array}{l}\text { British thermal unit per hour } \\
\text { per foot }[(\mathrm{Btu} / \mathrm{h}) / \mathrm{ft}]\end{array}$ \\
\hline
\end{tabular}




\begin{tabular}{|c|c|c|}
\hline watts per square meter $\left(\mathrm{W} / \mathrm{m}^{2}\right)$ & 0.317 & $\begin{array}{l}\text { British thermal unit per hour } \\
\text { per square foot }\left[(\mathrm{Btu} / \mathrm{h}) / \mathrm{ft}^{2}\right]\end{array}$ \\
\hline \multicolumn{3}{|c|}{ Concentration } \\
\hline milligrams per liter $(\mathrm{mg} / \mathrm{L})$ & 0.0001335 & ounce per gallon (oz/gal) \\
\hline \multicolumn{3}{|c|}{ Mass } \\
\hline metric ton (tonnes) & 1.102 & ton, short $(2,000 \mathrm{lb})$ \\
\hline metric ton per day (tonnes/d) & 1.102 & ton per day (ton/d) \\
\hline $\begin{array}{l}\text { tonnes per year per square } \\
\text { kilometer }\left[(\text { tonnes } / \mathrm{yr}) / \mathrm{km}^{2}\right]\end{array}$ & 2.8547 & $\begin{array}{l}\text { ton per year per square mile } \\
{\left[(\text { ton } / \mathrm{yr}) / \mathrm{mi}^{2}\right]}\end{array}$ \\
\hline metric ton per year (tonnes/yr) & 1.102 & ton per year (ton/yr) \\
\hline \multicolumn{3}{|c|}{ Density } \\
\hline kilogram per cubic meter $\left(\mathrm{kg} / \mathrm{m}^{3}\right)$ & 0.06242 & pound per cubic foot $\left(\mathrm{lb} / \mathrm{ft}^{3}\right)$ \\
\hline $\begin{array}{l}\text { metric ton per cubic meter } \\
\left(\text { tonnes } / \mathrm{m}^{3}\right)\end{array}$ & 0.03121 & ton per cubic yard $\left(\operatorname{ton} / \mathrm{ft}^{3}\right)$ \\
\hline $\begin{array}{l}\text { metric ton per cubic meter } \\
\text { (tonnes } / \mathrm{m}^{3} \text { ) }\end{array}$ & 0.8428 & ton per cubic yard (ton $\left./ \mathrm{yd}^{3}\right)$ \\
\hline
\end{tabular}

Temperature in degrees Celsius $\left({ }^{\circ} \mathrm{C}\right)$ may be converted to degrees Fahrenheit $\left({ }^{\circ} \mathrm{F}\right)$ as follows:

${ }^{\circ} \mathrm{F}=\left(1.8 x^{\circ} \mathrm{C}\right)+32$

Vertical coordinate information is referenced to the North American Vertical Datum of 1988 (NAVD 88).

Horizontal coordinate information is referenced to the North American Datum of 1983 (NAD 83).

Elevation, as used in this report, refers to distance above the vertical datum. 


\section{Abbreviations and Acronyms}

$\begin{array}{ll}\text { ADCP } & \text { acoustic Doppler current profiler } \\ \text { BAGS } & \text { Bedload Assessment in Gravel-bedded Streams model } \\ \text { CRKM } & \text { Carbon River kilometer } \\ \text { CwRKM } & \text { Cowlitz River kilometer } \\ \text { D50 } & \text { median particle size } \\ \text { D90 } & \text { size of sediment for which } 90 \text { percent of the sample is finer } \\ \text { DEM } & \text { digital elevation model } \\ \text { DNR } & \text { Department of Natural Resources } \\ \text { DRG } & \text { digital raster graphic } \\ \text { DO0 } & \text { digital orthophoto quadrangles } \\ \text { EDI } & \text { equal-discharge increment } \\ \text { FISP } & \text { Federal Interagency Sedimentation Project } \\ \text { GIS } & \text { geographic information system } \\ \text { GPS } & \text { global positioning system } \\ \text { LiDAR } & \text { light detection and ranging } \\ \text { MEWI } & \text { multiple equal-width increment } \\ \text { MORA } & \text { Mount Rainier National Park } \\ \text { NAIP } & \text { National Agriculture Imagery Program } \\ \text { NRKM } & \text { Nisqually River kilometer } \\ \text { NWIS } & \text { National Water Information System } \\ \text { PDO } & \text { Pacific Decadal Oscillation } \\ \text { PRKM } & \text { Puyallup River kilometer } \\ \text { RTK } & \text { real-time kinematic } \\ \text { TUGS } & \text { the Unified Gravel-Sand model } \\ \text { UTM10 } & \text { Universal Transverse Mercator zone 10 } \\ \text { USGS } & \text { U.S. Geological Survey } \\ \text { WRKM } & \text { White River kilometer } \\ \text { WSDOT } & \text { Washington State Department of Transportation } \\ & \end{array}$


This page left intentionally blank 


\section{Geomorphic Analysis of the River Response to Sedimentation Downstream of Mount Rainier, Washington}

By Jonathan A. Czuba, Christopher S. Magirl, Christiana R. Czuba, Kenneth H. Johnson, Theresa D. Olsen, Christopher A. Curran, Halley K. Kimball, and Casey C. Gish

“...know that Mount Rainier sits above us a pile of shattered rock surrendering minute by minute to the inexorable seduction of gravity." (Barcott, 1997)

\section{Abstract}

A study of the geomorphology of rivers draining Mount Rainier, Washington, was completed to identify sources of sediment to the river network; to identify important processes in the sedimentdelivery system; to assess current sediment loads in rivers draining Mount Rainier; to evaluate if there were trends in streamflow or sediment load since the early 20th century; and to assess how rates of sedimentation might continue into the future using published climate-change scenarios.

Rivers draining Mount Rainier carry heavy sediment loads sourced primarily from the volcano that cause acute aggradation in deposition reaches as far away as the Puget Lowland. Calculated yields ranged from 2,000 tonnes per square kilometer per year [(tonnes $\left./ \mathrm{km}^{2}\right) / \mathrm{yr}$ ] on the upper Nisqually River to 350 (tonnes $/ \mathrm{km}^{2}$ ) $/ \mathrm{yr}$ on the lower Puyallup River, notably larger than sediment yields of 50-200 (tonnes $/ \mathrm{km}^{2}$ )/yr typical for other Cascade Range rivers. These rivers can be assumed to be in a general state of sediment surplus. As a result, future aggradation rates will be largely influenced by the underlying hydrology carrying sediment downstream. The active-channel width of rivers directly draining Mount Rainier in 2009, used as a proxy for sediment released from Mount Rainier, changed little between 1965 and 1994 reflecting a climatic period that was relatively quiet hydrogeomorphically. From 1994 to 2009, a marked increase in geomorphic disturbance caused the active channels in many river reaches to widen. Comparing active-channel widths of glacier-draining rivers in 2009 to the distance of glacier retreat between 1913 and 1994 showed no correlation, suggesting that geomorphic disturbance in river reaches directly downstream of glaciers is not strongly governed by the degree of glacial retreat. In contrast, there was a correlation between active-channel width and the percentage of superglacier debris mantling the glacier, as measured in 1971. A conceptual model of sediment delivery processes from the mountain indicates that rockfalls, glaciers, debris flows, and main-stem flooding act sequentially to deliver sediment from Mount Rainier to river reaches in the Puget Lowland over decadal time scales. Greater-than-normal runoff was associated with cool phases of the Pacific Decadal Oscillation. Streamflow-gaging station data from four unregulated rivers directly draining Mount Rainier indicated no statistically significant trends of increasing peak flows over the course of the 20th century.

The total sediment load of the upper Nisqually River from 1945 to 2011 was determined to be $1,200,000 \pm 180,000$ tonnes/yr. The suspended-sediment load in the lower Puyallup River at Puyallup, Washington, was 860,000 $\pm 300,000$ tonnes/yr between 1978 and 1994, but the long-term load for the Puyallup River likely is about 1,000,000 $\pm 400,000$ tonnes/yr. Using a coarse-resolution bedloadtransport relation, the long-term average bedload was estimated to be about 30,000 tonnes/yr in the 
lower White River near Auburn, Washington, which was four times greater than bedload in the Puyallup River and an order of magnitude greater than bedload in the Carbon River. Analyses indicate a general increase in the sediment loads in Mount Rainier rivers in the 1990s and 2000s relative to the time period from the 1960 s to 1980 s. Data are insufficient, however, to determine definitively if post-1990 increases in sediment production and transport from Mount Rainier represent a statistically significant increase relative to sediment-load values typical from Mount Rainier during the entire 20th century.

One-dimensional river-hydraulic and sediment-transport models simulated the entrainment, transport, attrition, and deposition of bed material. Simulations showed that bed-material loads were largest for the Nisqually River and smallest for the Carbon River. The models were used to simulate how increases in sediment supply to rivers transport through the river systems and affect lowland reaches. For each simulation, the input sediment pulse evolved through a combination of translation, dispersion, and attrition as it moved downstream. The characteristic transport times for the median sediment-size pulse to arrive downstream for the Nisqually, Carbon, Puyallup, and White Rivers were approximately $70,300,80$, and 60 years, respectively.

\section{Introduction}

Mount Rainier, located in western Washington, rises to 4,392 meters (m) above sea level and contains the largest volume of glacial ice in the conterminous United States (Krimmel, 2002). The mountain is a recurrently active stratovolcano, having erupted during at least 10 distinct episodes in the past 2,600 years (Sisson and Vallance, 2008). The combination of glacial ice, active volcanism, and weathering promotes production of large volumes of colluvial debris. The volcano's proximity to sea level at Commencement Bay in Puget Sound-some Mount Rainier glaciers are as close as $85 \mathrm{~km}$ from Puget Sound (fig. 1) - results in a relatively steep network of mountainous rivers conducive to sediment transport between eruptive episodes.

Rivers and contributing catchments draining Mount Rainier (fig. 1) have presented acute challenges to flood-plain management in Pierce and King Counties. The upper Nisqually River, upstream of Alder Lake, has been subject to flooding and channel migration (Beason and Kennard, 2007; GeoEngineers, 2007). Similarly, the Puyallup River basin, which includes the Carbon and White Rivers, has been flood prone for the past two decades (Pierce County, 2012). Several large floods since 1990 raised concern among river managers that regional flood magnitudes may be increasing (Pierce County, 2012). Sediment accumulation in some river reaches and concomitant reductions in floodconveyance capacity (Czuba and others, 2010) have fostered the potential for significant economic impacts from future flooding, particularly where flood-plain development is extensive (Pierce County, 2012).

Over geological time scales, Mount Rainier cycles between increased sediment production during eruptive periods and smaller, but still significant, sediment production during inter-eruptive periods (Crandell, 1971; Scott and others, 1995). Similar sediment-production cycles are well documented on other Pacific Northwest stratovolcanoes (Major and others, 2000; Pierson and others, 2011). From the early 20th century to the present, Mount Rainier has been in an inter-eruptive period. Although limited eruptive activity may have occurred in 1894 (Sisson and Vallance, 2008), the generation of sediment beyond normal inter-eruptive magnitudes was not documented. During intereruptive periods, rivers draining Mount Rainier carry heavy sediment loads relative to rivers not draining volcanoes (Czuba and others, 2011). High sedimentation rates have been documented in the lowland reaches of rivers draining Mount Rainier, and it has long been recognized that sediment production from Mount Rainier increases overall sediment load (Fahnestock, 1963; Crandell, 1971; 
Mills, 1976; Nelson, 1978; Dunne, 1986; Prych, 1988; Sikonia, 1990; Scott and others, 1995; Hoblitt and others, 1998; Czuba and others, 2010).

Until the late 1980s, large volumes of sediment commonly were removed through in-channel dredging from select reaches of the river network in the Puget Lowland (Prych, 1988; Czuba and others, 2010; Herrera Environmental Consultants, 2010), partially offsetting sediment input from the upper drainage basin. Sediment removal largely ceased in the Puyallup River basin by the middle 1990s partly to prevent adverse effects on the aquatic habitat containing federally listed salmonids, including Chinook salmon [Oncorhynchus tshawytscha] and steelhead [O. mykiss], which are listed as threatened in Puget Sound, as well as coho salmon [O. kisutch], listed as a species of concern (National Oceanic and Atmospheric Administration, 2010a). Other factors that contributed to the cessation of gravel removal in the region included the challenges of obtaining necessary permits, the reductions in rivermaintenance budgets, and the recognition that flood-reduction benefits from gravel removal are temporary (Pierce County, 2012).

Recent observations of increased hydrogeomorphic activity in rivers draining Mount Rainier, including several debris flows (Copeland, 2009; Lancaster and others, 2012), large floods, and aggradation in the rivers within the national park (Beason, 2007), suggest that production and transport of alluvial material from the volcano may be increasing. Inevitably, sediment delivered to rivers draining the volcano will be transported downstream, but the timing of arrival of new sediment and the magnitude of impacts on downstream channel form are unknown. Pierce County recently developed a flood-hazard-management plan and an environmental-impact statement to guide flood-management efforts in future decades (Pierce County, 2012). To assist with development of the plan, Pierce and King Counties requested that the U.S. Geological Survey (USGS) conduct a cooperative study of the geomorphology of rivers draining Mount Rainier.

\section{Purpose and Scope}

This report documents an assessment of historical and current fluvial sediment loads in rivers draining Mount Rainier; the sources of sediment within the watershed; important sediment-production and sediment-delivery processes within the watershed; long-term trends of increasing discharge or sediment loads; and the anticipated magnitude of sedimentation 25 and 50 years into the future using published climate-change predictions. The focus of the study is on the Puyallup, Carbon, White, and upper Nisqually Rivers, although all rivers draining Mount Rainier are considered as is the sedimentdelivery potential from contributing watersheds.

Specific data sets used for the study included light detection and ranging (LiDAR) digitalelevation models (DEMs) from multiple sources; meteorological data collected since 1986; hydrologic, geologic, and land-use data from within the watershed; and available sediment-load data collected from the Puyallup, White, and Carbon Rivers. Literature reviews of sediment loads in regional rivers, glacial data sets from Mount Rainier, and future-climate predictions affecting peak-flow hydrology also were used. Aerial imagery from 1965, 1994, and 2009 of the upper reaches of all rivers directly draining Mount Rainier glaciers were analyzed to determine late 20th-century trends in active-channel width. Geographic, topographic, and hydrologic data were used to assess the potential for sediment production from subcatchments in the upper Nisqually River basin and the greater Puyallup River basin. Finally, one-dimensional sediment-transport models were developed for the main-stem river network to assess how sediment produced on the volcano moves downstream over time. These models were used to compare sediment-delivery rates on each river; evaluate where ecologically sensitive river-management practices like setback levees or gravel scalping might more efficiently increase flood-conveyance 
capacity; and predict how lowland reaches of analyzed rivers will respond to current and future sediment pulses.

\section{Description of Study Area}

Mount Rainier is a 500,000-year old recurrently active stratovolcano (Sisson and others, 2001) located in the Cascade Range, a north-trending volcanic arc formed by the subduction of the Juan de Fuca plate under the North American plate (Pringle, 2008). The Cascade Range is between 6 and 15 million years old (Reiners and others, 2002). The Puget Lowland is a physiographic fore-arc basin located west of the Cascade Range, and Mount Rainier volcanism is centered west of the crest of the Cascade Range. The Nisqually and Puyallup River basins drain the southern, western, and northern flanks of Mount Rainier and empty into Puget Sound (fig. 1). The Cowlitz River drains the eastern flank of Mount Rainier and empties into the Columbia River. The retreat of the Puget Lobe of the Cordilleran Ice Sheet from the Puget Lowland about 16,000-17,000 years ago (Porter and Swanson, 1998) reset the network of rivers draining the Cascade Range. As a result, the Nisqually and Puyallup River networks in the Puget Lowland are still adjusting to the effects of the ice sheet, incising where they cross glacial till deposits and aggrading where river slope decreases in former embayments of Puget Sound (Collins and Montgomery, 2011).

The climate of the study area is predominantly wet and temperate (National Oceanic and Atmospheric Administration, 2010b). The prevailing wind direction is from the south or southwest during the rainy season (October to June) and from the northwest during the relatively dry summer from July to September. During the winter, cold air from the Canadian interior occasionally flows southward, covering the region. The average January maximum temperature in the Puget Lowland is about $6^{\circ} \mathrm{C}$ $\left(43^{\circ} \mathrm{F}\right)$ and the minimum is about $-1^{\circ} \mathrm{C}\left(30^{\circ} \mathrm{F}\right)$. During July, the average maximum temperature is about $24^{\circ} \mathrm{C}\left(75^{\circ} \mathrm{F}\right)$ and the minimum is about $10^{\circ} \mathrm{C}\left(50^{\circ} \mathrm{F}\right)$. Annual precipitation in the Puget Lowlands is about $1,000 \mathrm{~mm}$ (40 in.), and the winter-season snowfall is about $380 \mathrm{~mm}$ (15 in.). Precipitation increases with elevation; annual rainfall in the Cascade Range in high-elevation catchments typically is 1,550-2,500 mm (60-100 in.) and total annual snowfall is between 10 and $15 \mathrm{~m}(400-600 \mathrm{in}$.) at elevations of 1,200-1,600 m (4,000-5,500 ft) (National Oceanic and Atmospheric Administration, 2010b).

The Muddy Fork Cowlitz and the Ohanapecosh Rivers (fig. 1) are unregulated by dams or diversions downstream to Packwood, Washington. The Nisqually River and its tributaries flow into Alder Lake (fig. 1), which is ponded behind Alder Dam trapping much of the river sediment load (Nelson, 1974). The Carbon River is unregulated. The Puyallup River has a low-head diversion dam for power production upstream of Orting (fig. 1), but the facility is designed to pass peak flows with no effect on peak-flow magnitude. Flood management for the lower Puyallup River valley is provided by Mud Mountain Dam, which was completed on the White River (fig. 1) in 1948 (U.S. Army Corps of Engineers, 2009). The U.S. Army Corps of Engineers operates Mud Mountain Dam to control flooding on the lower Puyallup River. During peak events on the Puyallup River, flow on the White River is retained by Mud Mountain Dam, causing water to pool in the reservoir and depositing large volumes of sand and coarser sediment, which can accumulate to depths of as much as $12 \mathrm{~m}$ (Rick Emry, U.S. Army Corps of Engineers, written commun., 2010). When the flood peak on the lower Puyallup River has abated, sediment (as large as $0.5 \mathrm{~m}$ ) is sluiced through the dam, preventing aggradation of the channel invert of the White River (Rick Emry, U.S. Army Corps of Engineers, written commun., 2010). Mud Mountain Dam traps a portion of the arriving White River bedload, and Dunne (1986) postulated that most coarse-grained bedload was retained in reservoir storage, at least through the 1970s. But bedload storage in the reservoir will decrease through time as the trap efficiency of the coarsest sediment 
decreases. The current trap efficiency of bedload within the reservoir is unknown, but observations of rapid changes in the river stage just downstream of the dam since the 1970s (Czuba and others, 2010) and observations of little change to the water-surface elevation of the White River through the reservoir reach suggests that a sizeable proportion of bedload now passes Mud Mountain Dam. Along the lower White River, a low-head diversion dam upstream of Auburn occasionally diverts flow to Lake Tapps during low flow, but this structure passes bedload and does not affect peak-flow magnitude. Water from Lake Tapps is returned to the White River downstream of Auburn.

Mean annual discharge for the Puyallup River at Puyallup gage (USGS streamflow-gaging station No. 12101500) is $94 \mathrm{~m}^{3} / \mathrm{s}\left(3,320 \mathrm{ft}^{3} / \mathrm{s}\right)$ for the period of record (table 1) with dominant hydrologic inputs from winter rainfall and snowmelt in the spring and summer. Late summer and autumn discharge is sustained by groundwater and glacial melt from Mount Rainier; the headwaters of all main-stem rivers draining Mount Rainier originate from the glaciers. The largest peak-flow events in the basin are associated with heavy autumn or winter precipitation associated with atmospheric rivers, strong synoptic systems from the Pacific Ocean that tap into tropical moisture sources (Neiman and others, 2011). At the Puyallup River at Puyallup, the flood of record of $1,610 \mathrm{~m}^{3} / \mathrm{s}\left(57,000 \mathrm{ft}^{3} / \mathrm{s}\right)$ occurred in December 1933, prior to construction of Mud Mountain Dam. For this lower Puyallup River site, 6 of the 10 largest annual peak events have occurred since 1980 , including $1,360 \mathrm{~m}^{3} / \mathrm{s}\left(48,200 \mathrm{ft}^{3} / \mathrm{s}\right)$ on January 8, 2009 (2nd largest peak in the record), and 1,120 m3 $/ \mathrm{s}\left(39,700 \mathrm{ft}^{3} / \mathrm{s}\right)$ on November 7, 2006 (10th largest peak in the record). These recent large peak events occurred despite flow regulation by Mud Mountain Dam. The November 2006 event was more significant farther upstream, and peaks of record of $411 \mathrm{~m}^{3} / \mathrm{s}\left(14,500 \mathrm{ft}^{3} / \mathrm{s}\right), 609 \mathrm{~m}^{3} / \mathrm{s}\left(21,500 \mathrm{ft}^{3} / \mathrm{s}\right)$, and $617 \mathrm{~m}^{3} / \mathrm{s}\left(21,800 \mathrm{ft}^{3} / \mathrm{s}\right)$ were established for the Carbon River at Fairfax gage (12094000), the Puyallup River near Orting gage (12093500), and the Nisqually River near National gage (12082500), respectively. Widespread flooding also affected the region in February 1996 when discharge peaked at $1,320 \mathrm{~m}^{3} / \mathrm{s}\left(46,700 \mathrm{ft}^{3} / \mathrm{s}\right)$ on the Puyallup River at Puyallup (third largest peak in the record) and $600 \mathrm{~m}^{3} / \mathrm{s}\left(21,200 \mathrm{ft}^{3} / \mathrm{s}\right)$ on the Nisqually River near National. Smaller peak-flow events usually occur in late spring and early summer with the seasonal snowmelt. Hydrologic data at USGS streamflow-gaging stations are typically reported by water year (WY), which starts October 1 of the previous calendar year and extends to September 30.

\section{Fluvial Geomorphology}

Rivers carry water, sediment, and wood, all of which influence channel form (Leopold and others, 1964). The entrainment, transport, and deposition of sediment is spatially and temporally complex, and assessing or predicting how sediment moves downstream and the morphologic responses to sediment transport in a particular river can require extensive scientific effort. Understanding fluvial processes requires a standard terminology of mechanistic function and insight into the interaction between sediment-transport modes. This section discusses the terminology and function of river processes as they relate to sediment transport, sediment deposition, and the influence of wood in river systems draining Mount Rainier. The reader familiar with concepts in geomorphology can skip this section without loss of continuity in the report.

\section{Sediment Load}

The sediment load carried by a river, also referred to as sediment flux or total sediment discharge, is defined as the rate of transfer of non-dissolved, inorganic particles flowing past a given cross section within the stream. Sediment load typically is reported in units of mass per time, and the total sediment load is composed of suspended-sediment load and bedload. Suspended-sediment load is the fraction of fine sediment carried by turbulent eddies within the flowing river that can settle out in 
quiet backwaters of the river corridor or when discharge decreases. Bedload is the fraction of moving sediment too heavy to be carried in suspension that moves along the river bottom by rolling, sliding, or saltation.

At low and moderate streamflow, overall bedload is small and the riverbed remains largely static. As streamflow increases, particles on the riverbed mobilize, resulting in increased bedload. Concurrently, the load of suspended sediment increases with increasing discharge, as does the characteristic median size of particles in suspension. Particles from both suspended-sediment load and bedload make up the bed material of the river bottom, and the particle-size threshold between suspended-sediment load and bedload is related to discharge. Bed-material load is the fraction of moving sediment that deposits on and composes the river bed, including all bedload and the coarser fraction of the suspended-sediment load.

As individual particles move downstream, collisions with other particles and the bed cause breakage or surface ablation in a process termed "attrition" (Collins and Dunne, 1989). Through attrition and selective transport, river-bed material and bedload particle size decreases in the downstream direction (Sklar and others, 2006). In many rivers, there is a gravel-sand transition that forms by particle fining or changes in channel hydraulics (Hoey and Bluck, 1999; Ferguson, 2003; Singer, 2008; Labbe and others, 2011).

\section{Sediment Measurement}

Suspended-sediment load and bedload are sampled using specific protocols to minimize errors and enable comparability between different river systems (Edwards and Glysson, 1999). Even when using these protocols, large variability in sediment loads in the flowing river make precise and comprehensive sediment-load measurements difficult to obtain (Horowitz, 2003). Heterogeneous distributions of suspended-sediment load and bedload are common in most river systems and vary by position, hydrologic conditions in the catchment, geomorphic conditions in the local river reach, and discharge.

Similarly, heterogeneity creates uncertainties when assessing the characteristic size of bed material. The most common approach to determining bed material size is with a Wolman pebble count (Wolman, 1954), but differences in application of the technique, as well as variability in bed surfaces, can create deviations in sample populations. The most effective technique to improve accuracy in measuring both sediment load and bed material is to collect replicate samples in sufficient quantities to enable the evaluation of the variation of the total population of interest.

\section{Aggradation and Incision}

Aggradation is the general trend of sediment accumulation in a particular river reach, which, in turn, causes an increase in the river-bed elevation, as well as the stage for a given discharge. Incision, or degradation, is the general trend of net sediment removal from a river reach, which lowers the riverbed elevation and decreases the stage for a given discharge. Lane (1955) introduced a qualitative relation that the product of discharge and slope is proportional to product of bedload and representative of bedmaterial size for a given river. It follows from Lane's relation that conceptually, increases in bedload or bed-material size with no concurrent change in hydrologic discharge or river slope results in aggradation. Conversely, decreases in bedload under constant hydrologic discharge and slope results in net local incision. Similarly, if bedload and bed-material size are constant, decreases in discharge would result in aggradation and increases in discharge would result in incision. Though Lane's simple relation has limitations, and has been improved and clarified by other researchers (see Schmidt and Wilcock, 
2008; Dust and Wohl, 2012), the underlying concept remains a useful and effective tool for understanding geomorphic response of alluvial river systems.

Alluvial sections of gravel-bed rivers subject to increased bedload and aggradation often respond with channel widening and braiding (Lyons and Beschta, 1983; Knighton, 1989; Madej and Ozaki, 1996; Miller and Benda, 2000; Lisle, 2008; Pierson and others, 2011), particularly if the aggradation is caused by a pulse of finer-grained sediment translating through the reach (Lisle, 2008). Conversely, decreasing sediment loads typically result in channel incision and narrowing (Knighton, 1989; Lisle, 2008; Madej and others, 2009). Leopold and Maddock (1953), using the flume data of Gilbert and Murphy (1914), stated that for constant velocity and discharge, an increase in channel width is associated with an increase in bedload. These particular channel responses of braided mountain rivers are pertinent to the present study because of the availability of aerial imagery showing channel form and the relative dearth of direct bedload measurements close to the mountain.

A graded river represents an alluvial system that balances sediment supply and the sedimenttransport capacity to move bed material, whereby there is no long-term aggradation or incision (Leopold and others, 1964). Transport capacity to move bed material is often assumed to be proportional to the available stream power of a river, which is proportional to the product of discharge and slope (Bagnold, 1966). In rivers where sediment supply from the contributing catchment is less than the transport capacity, the long-term tendency of the river is to incise. Such rivers are often referred to as "supplylimited" or under conditions of "sediment deficit" (Schmidt and Wilcock, 2008); bedrock-controlled rivers fall into this category (Montgomery and Buffington, 1997). Conversely, if the sediment supply from the contributing catchment exceeds the transport capacity of the river, the river is categorized as "transport-limited" or under conditions of "sediment surplus" (Schmidt and Wilcock, 2008). No river is ever in a condition of pure sediment surplus or pure sediment deficit. Instead, the specific condition of the river falls in a spectrum between the two states, and varies in space and time. Rivers in sediment deficit can switch to sediment surplus after a large storm causes widespread landslides and a temporary oversupply of sediment (Brummer and Montgomery, 2006). Conversely, rivers in a state of sediment surplus can become sediment starved if sediment influx from the catchment decreases for a period of time. Additionally, rivers can be in sediment surplus in one particle-size class and in sediment deficit in another size class (Schmidt and Wilcock, 2008).

\section{Debris Flows}

A debris flow is a rapidly moving slurry of water of 70-90 percent sediment (by weight) with rheological properties that enable the efficient downstream transport of large volumes of sediment (Pierson and Costa, 1987; Costa, 1988). Granular collisions in the flow and a matrix of water and finegrained sediment give debris flows the competence to buoy large boulders and transport them several kilometers downstream. The sediment-transport competence of debris flows far exceeds water flow of similar depth and discharge, and debris flows are a predominant, formative geomorphic process in many mountainous rivers (Dietrich and Dunne, 1978; Reneau and Dietrich, 1991; Benda and Dunne, 1997; Brummer and Montgomery, 2006).

Debris flows typically spawn from loose, unconsolidated colluvium or alluvium on hillslopes between 30 and 45 degrees. Heavy rainfall or the rapid melting of snow or glaciers can increase pore pressure of water in the soil column greater than a failure threshold, thus initiating movement of the hillslope (Iverson, 2000; Montgomery and others, 2002). If the clay content and water saturation is sufficient, the hillslope failure can continue to move downslope entering tributary and main-stem drainage networks. In steeper tributaries, debris flows scour and recruit additional sediment growing in volumetric size, through a process termed "bulking up." In wider stream sections or reaches where the 
valley widens, debris flows deposit sediment and shrink in volume. The travel distance of the debris flow, as a slurry capable of carrying boulders, is a function of the total volume of the debris flow and the relative clay content (Iverson and others, 1998; Griswold and Iverson, 2008). Debris flows with high clay content can more effectively hold water in the matrix and extend travel distance (Scott and others, 1995). After the debris flow deposits its coarse sediment, the remaining water/fine-sediment matrix can move downstream as hyperconcentrated flow, containing 40-70 percent sediment by weight (Beverage and Culbertson, 1964; Pierson, 2005). Although rheologically distinct from debris flows, hyperconcentrated flows have the competence to transport significant quantities of sediment downstream.

The term "debris flow" refers to any rapid mass movement of rocky debris mobilized by water. The term "mudflow" has been defined as a debris flow that contains more than 50 percent sand-, silt-, or clay-sized particles (Varnes, 1978). The differences in rheological properties and transport competence between debris flows and mudflows are so subtle that contemporary researchers have tended exclusively to use the term debris flow. Nevertheless, the term persists: Both the Osceola and the Electron Mudflows were named by early researchers, and news outlets are more likely to refer to debris flows as mudflows, an intuitive term for the general public. The term "lahar" is an Indonesian word that is used as a general designation to denote a debris flow that originates from an active volcano, whether triggered by an eruption or not (Crandell, 1971; Pierson and Scott, 1985; Vallance and Scott, 1997). In a strict technical sense, all debris flows originating from the flanks of Mount Rainier, regardless of size, are lahars. In 2003, however, to clarify communication protocol with emergency services, the public, and the press, Mount Rainier National Park made the administrative decision to use the term lahar only when describing large debris flows that were likely to leave the park boundary. The park service now reserves the term debris flow for smaller events that remain within the park. This report follows a similar convention.

Wood

Historically, all rivers in the Pacific Northwest carried large quantities of wood that shaped channel form and ecological function (Abbe and Montgomery, 1996; O'Connor and others, 2003; Fox and Bolton, 2007; Collins and others, 2012). Within Mount Rainier National Park, where logging was never permitted, there appears to be a relative stasis between the position of old-growth forests and the active channel of rivers draining Mount Rainier (Kennard and others, 2011). Although the lower $20 \mathrm{~km}$ of the Nisqually River approaching Puget Sound flows through a relatively intact riparian corridor where the function of large wood in the river is similar to pre-development conditions (Collins and others, 2012) and riparian wood is still widespread within Mount Rainier National Park, the quantity of wood in all other main-stem river reaches draining Mount Rainier has been significantly reduced. This reduction in wood is particularly acute near population centers. In a forensic analysis of damaging regional floods of November 1906, Chittenden (1907) recommended the removal and control of drift wood as part of a three-pronged strategy to control floods (the other two components being river straightening and the construction of an extensive levee system). When the lower White River was leveed and straightened between 1914 and 1919 by the Inter-County River Improvement Commission, $360,000 \mathrm{~m}^{3}$ of logs and drift wood from the flood plain and underlying alluvium were removed and burned (Roberts, 1920). Although the quantity of wood present in lowland sections of the Puyallup, Carbon, and White Rivers is significantly less than before development, wood is still recruited from the adjacent flood plain. Though this wood provides ecological benefit, it can also raise stage during floods (Brummer and others, 2006) or direct flow toward revetments causing damage and increase the risk of 
failure of flood-management structures and subsequent flooding. Although important, the impacts and function of wood to Mount Rainier rivers was not a focus in this study.

\section{Conceptual Model of Sediment Delivery from Mount Rainier}

Conceptually, sediment is transported from Mount Rainier to the Puget Lowland through a sequence of glacial and fluvial processes (fig. 2). High on the mountain, glaciers entrain sediment through bedrock erosion and carry colluvium deposited by rockfalls. Englacial sediment is transported by glaciers to lower elevations and deposited in moraines. Debris flows mobilize sediment from moraines as well as from superglacial deposits transporting sediment downstream into the river network. Finally, floods work to transport coarse-grained and fine-grained sediment down main-stem rivers to the Puget Lowland and Puget Sound.

\section{Weathering and Rockfall}

Chemical and physical weathering on Mount Rainier promotes the production of large volumes of sediment from the flanks of the stratovolcano. Near the summit, hydrothermal alteration of the extrusive igneous bedrock (Frank, 1995) produces weak, clay-rich material susceptible to sector collapse and large lahars (Scott and others, 1995; Reid and others, 2001; Sisson and others, 2001). Between eruptive episodes or large-scale sector collapse, the chemical weathering of the mountain bedrock causes rockfalls from exposed headwalls that deposit predominantly on glaciers. Small rockfalls are common throughout the summer, supplying new sediment to glaciers. Large rockfalls can mobilize into debris avalanches that move down the glacier as granular flows.

In June 2011, a series of large debris avalanches, which started as rockfalls, blanketed the upper Nisqually Glacier. Because of the elevation of the deposit and the danger in the fall zone, no forensic data of the June 2011 debris avalanche were directly collected, but the aerial extent of the debris avalanche, as visible on 2011 National Agricultural Imagery Program (NAIP) imagery (U.S. Department of Agriculture, 2011), indicated the debris avalanche traveled a distance of more than $2 \mathrm{~km}$ down the face of the upper glacier and covered about $500,000 \mathrm{~m}^{2}$ of ice. If the deposit is assumed to be $1-2 \mathrm{~m}$ thick, the total volume of sediment added to the Nisqually Glacier was between 0.5 and 1.0 million $\mathrm{m}^{3}$.

Larger rockfalls and debris avalanches have been documented (Crandell and Fahnestock, 1965; Frank, 1985; Scott and Vallance, 1995). The largest rockfall/debris avalanche in the Mount Rainier historical record occurred in December 1963, when 11 million $\mathrm{m}^{3}$ fell during at least seven separate avalanches that traveled a distance of more than $6 \mathrm{~km}$ down Emmons Glacier and left a sizeable deposit on the valley floor in front of the glacier terminus (Crandell and Fahnestock, 1965) (fig. 3). A photograph of the region downslope of the Emmons Glacier terminus taken in the summer following the debris avalanche shows the extent of the debris coverage (fig. 3B), and a photograph taken from a similar vantage point five years later shows the progression of the rockfall-sourced sediment down the White River (fig. 3C). By the summer of 2011, vegetation had grown on much of the 1963 debrisavalanche surface, and fluvial processes appeared to have significantly reworked the deposit and transported a portion downstream (fig. 3D).

\section{Glaciation}

In the geologic record, aggradation in fluvial networks is often associated with periods of glacial advance (Schumm, 1965; O'Connor and others, 2001). In many systems, however, studies of proglacial 
sedimentation show complex patterns of aggradation and incision (Maizels, 1979; Leonard, 1997), and debris released by proglacial or postglacial regions of retreating glaciers have triggered increased sediment loads and downstream aggradation (Church and Ryder, 1972; O'Connor and Costa, 1993; Hallet and others, 1996).

Mount Rainier glaciers have been the focus of numerous studies (for example, Harrison, 1956; Sigafoos and Hendrick, 1961; Fahnestock 1963; Veatch, 1971; Crandell and Miller, 1974; Sigafoos and Hendricks, 1972; Metcalf, 1979; Mills, 1979; Burbank, 1981; Driedger and Kennard, 1986; Heine, 1998; Nylen, 2004; Sisson and others, 2011). The movement of glaciers over bedrock promotes sediment entrainment through plucking and abrasion. Mills (1979) estimated the Nisqually Glacier produced a fine-grained suspended-sediment load of about 60,000 tonnes/yr, predominantly sourced from abrasion and released during the summer melt season. Metcalf (1979) calculated the suspendedsediment load from subglacial abrasion of Nisqually Glacier to be 30,000 tonnes/yr. Sediment sourced from abrasion processes is believed to be the primary cause of "glacial flour," the high-sediment concentration in glacier-draining streams observed during warm summer months (Fahnestock, 1963; Mills, 1979). Englacial sediment, sediment carried within or on top of the flowing ice matrix, also represents a significant volume of total glacial sediment load. Englacial sediment on Mount Rainier is predominantly sourced from rockfalls and debris avalanches that occur high on the mountain.

Glacier retreat in the Pacific Northwest during the 20th century has been widely documented (Spicer, 1986; Pelto and Riedel, 2001; Pelto, 2006), and glacier response on Mount Rainier has mostly reflected the regional trends (Nylen, 2004; Sisson and others, 2011). Nylen (2004) determined that, between 1913 and 1971, glacier cover on Mount Rainier decreased 18.5 percent and glacier volume decreased 22.7 percent. From 1970 to 2008, Mount Rainier lost another 14 percent by volume of glacier ice and perennial snow (Sisson and others, 2011). Most glaciers on the mountain have retreated since 1980, with the largest documented glacier retreat on the southern flank of the volcano. Rockfall debris on Emmons Glacier (mostly from the 1963 event) caused a modest advance and thickening of the glacier since 1970 (Sisson and others, 2011). Similar debris mantling has insulated the Carbon and Winthrop Glaciers, mitigating tendencies toward glacier retreat (Nylen, 2004; Sisson and others, 2011).

The flux of sediment carried downslope by an active glacier is the product of the glacier velocity and the sediment in or on the flowing ice matrix. Seasonal temperature and snowfall are the primary climatic variables influencing glacial dynamics and whether the glacier is in a state of advance or retreat. Englacier sediment is deposited in lateral and terminal moraines near the glacier terminus. Most lateral and terminal moraines on Mount Rainier are located at low elevations and are subject to mobilization into debris flows.

\section{Mount Rainier Debris Flows}

On Mount Rainier, debris flows are initiated by rapid summer melting of glaciers and subsequent outburst flooding that mobilize sediment (Walder and Driedger, 1994) or by intense rainfall that saturates loose, unconsolidated soils on steep slopes near the glacier terminus (Copeland, 2009; Lancaster and others, 2012). Most of the large rainfall-induced debris flows documented in the historical record occurred in October or November, presumably with little antecedent snowpack. No debris flows have been recorded from December to May, when snowpack is thicker (Nick Legg, Oregon State University, written commun., 2011). These historical observations, however, also may reflect the fact that fewer visitors are in the park during the winter months, particularly along the Carbon and White Rivers. The retreat of most glaciers on Mount Rainier during the 20th century exposed fresh colluvium suggesting a correlation between recent observed debris-flow activity and glacial retreat with intense 
rainfall from strong autumnal atmospheric rivers acting as a primary triggering mechanism (Copeland, 2009; Lancaster and others, 2012).

The largest historical debris-flow event was the 1947 Kautz Creek debris flow, which mobilized about 40 million $\mathrm{m}^{3}$ of material following heavy rainfall in October (Crandell, 1971). Following the 1947 event, periodic debris flows continued to occur in the Kautz drainage about every 10 years (Driedger and Fountain, 1989; Nick Legg, Oregon State University, written commun., 2011). The greatest level of sustained debris-flow activity on Mount Rainier occurred in Tahoma Creek with at least 28 individual debris-flow events from 1967 through 2006 (Walder and Driedger, 1994; Copeland, 2009). Debris flows in the Nisqually River basin triggered by summer glacial melt were common in the 1990s (Walder and Driedger, 1994; Copeland, 2009). In the 2000s, the entire mountain experienced a spate of debris-flow activity associated with heavy autumn rainfall in 2003, 2005, and 2006 (Copeland, 2009).

On the southern side of Mount Rainier, documented debris flows have initiated from steep slopes in recently deglaciated terrain (Copeland, 2009; Lancaster and others, 2012). Few direct observations of debris flows are available from the northern and western sides of the mountain, but reconnaissance of the Carbon River near the glacier terminus, conducted as part of this study, showed debris flows had traveled at least $2 \mathrm{~km}$ downstream of the Carbon Glacier within the past 10 years and that extensive debris-flow levees were present within $300 \mathrm{~m}$ of the glacier. A wide active channel and widespread burial of flood-plain forests along the upper Carbon River just downstream of the glacier suggest recent and significant trends in sedimentation. Evidence along the upper Carbon River indicates that debris flows are an active part of the transport process, despite minimal 20th-century glacial retreat.

Debris flows efficiently transport sediment from steeper sections of the fluvial network near the glaciers to lower elevation fluvial reaches (fig. 2). This debris-flow transport is important to the overall delivery process because the upstream reaches of the glacier-draining rivers do not have the hydrologic stream power sufficient to mobilize larger particles. Without debris flows, the majority of debris in terminal and lateral moraines would remain near the glacier. Debris flows carry sediment into downstream fluvial reaches where flow competence increases and stream power is sufficient to mobilize gravel, cobbles, and boulders into the river sediment load.

\section{Sediment Transport in River Network}

Once sediment is delivered to the primary fluvial network, transport to downstream reaches and the geomorphic response of the river channel form is dictated by the balance of hydrology and sediment load (Lane, 1955). High-gradient fluvial reaches, with slopes greater than about $0.02 \mathrm{~m} / \mathrm{m}$, are subject to active aggradation and incision with the potential to move into forested terraces of the flood plain adjacent the active river channel (fig. 2). Because these steeper reaches tend to be within the national park boundary, the presence of old-growth forests resists channel migration and avulsions of the river into the forested flood plain (Kennard and others, 2011).

Downstream of the national park, rivers flow through mountainous reaches with slopes between 0.002 and $0.02 \mathrm{~m} / \mathrm{m}$. The background hydrology in these reaches, coupled with the relatively steep slopes, tends to efficiently transport sediment with relatively little long-term aggradation or incision. Some river reaches, however, can experience active-channel migration and avulsions, particularly where forestry and development have removed large anchor trees (Collins and others, 2012).

Upon exiting the mountain front, rivers draining Mount Rainier enter the Puget Lowland where slope decreases, promoting long-term aggradation and the build-up of alluvial fans (Dragovich and others, 1994; Collins and Montgomery, 2011). Changes to river corridors from engineering and development, as well as flow regulation, further complicate river responses in the lowland. 
Sediment deposited in main-stem rivers of the Mount Rainier fluvial network is transported downstream by infrequent large and frequent intermediate-sized flows (fig. 2). Although the geomorphic work done by intermediate flows is less than the work done by large events, intermediate flows accomplish work through event frequency and serve as an important contributor to the total sediment load (Langbein and Leopold, 1964). Large, infrequent floods transport and deposit the largest particles in the bed, which establishes the geomorphic framework of bars and pools in the river corridor. Channel migration, widening, and avulsions tend to occur during larger flood events. Smaller, morefrequent peak-flow events do not exert the channel-forming influence on river morphology as the larger events, but these intermediate flows transport a significant portion of the total sediment load. The combination of frequent moderate-magnitude flows and infrequent large floods are responsible for transporting large volumes of sediment to depositional reaches in river systems draining other stratovolcanoes (Major, 2004; Pierson and others, 2011).

\section{Serial Sediment Delivery}

The heavy sediment loads in rivers draining Mount Rainier depend on contributions of four dominant sediment-delivery processes working in unison: (1) rockfalls, (2) glaciers, (3) debris flows, and (4) floods. Rockfalls and debris avalanches onto glaciers at the highest elevations of the mountain, promoted by weathering and hydrothermal alteration of the volcano bedrock structure, initiate the delivery of sediment downstream. This rockfall sediment is carried by the downslope movement of glaciers. Debris flows then episodically transport sediment from glacial moraines to downstream reaches of the river network. Heavy rainfall and concomitant large floods transport sediment to lowland reaches where the coarser material deposits in aggrading reaches and the finer sediment is eventually transported to Puget Sound. If any of these processes slow or cease, the sediment loads delivered to lowland reaches would decrease over time. Conversely, if these processes increase concurrently, then sediment delivery to lowland reaches would increase. More research is needed to better understand the relative contributions of each process in overall sediment delivery, specifically related to timing of delivery and limiting processes in the sequence. For example, there is likely a phase delay in the timing of one dominant sediment-delivery process to the next which can affect sediment arrival downstream, and sediment can reside for periods of time in temporary sediment reservoirs (for example, glacial moraines or flood-plain storage). However, in general, these four processes act to meter sediment delivery to lowland reaches.

\section{Geomorphic Characteristics of Mount Rainier Rivers}

Mount Rainier rivers have been influenced by the geology of the Cascade Range and Puget Lowland as well as the large sediment loads supplied by the volcano.

\section{River Centerlines and Stationing}

Using available LiDAR DEMs and aerial images (appendix A, table A1), digitization of the active channel and centerline was completed for each main-stem river in the study (Puyallup, Carbon, White, Nisqually, and Cowlitz Rivers). River centerlines also were digitized to provide consistent river stationing along the dominant flow path of the active channel. These digitization products were used to compute longitudinal elevation profiles and active-channel widths for each river and to construct onedimensional river-hydraulic/sediment-transport models. Details of the digitization are discussed further in section "Model Framework." River kilometer stationing along each main-stem river was established from upstream to downstream, with river-kilometer 0 starting near the terminus of the glacier for each 
main-stem river (fig. 1). Stationing for each main-stem river was differentiated using the following naming convention: Nisqually River (NRKM), Puyallup River (PRKM), Carbon River (CRKM), White River (WRKM), and Cowlitz River (CwRKM). River centerlines (fig. 1) were digitized from the apparent flow path using LiDAR data in order to compute an elevation profile of each tributary entering main-stem rivers.

\section{Longitudinal River Profiles}

Longitudinal profiles of Mount Rainier rivers and tributaries show the prominent high-gradient nature of the drainage network from the stratovolcano to lowland reaches (fig. 4). For example, the Puyallup River grades steeply from its source glacier, the Puyallup Glacier, through an upper alluvial reach to a relatively steep bedrock canyon at the mountain front of the Cascade Range located from about PRKM 27 to 35 (fig. 4A). After flowing through an alluvial reach near the volcano, the Carbon River cuts through a similar bedrock canyon at a similar elevation from about CRKM 27 to 33 (fig. 4C). The White River near Mud Mountain Dam (WRKM 71.0) also cuts through a bedrock constriction, though the length of the White River bedrock reach is shorter than those along the Puyallup and Carbon Rivers (fig. 4B). These bedrock canyons, common on Cascade Range rivers exiting the mountain front and entering the Puget Lowland, are geologic reflections of the influence of the Puget Lobe of the Cordilleran Ice Sheet (Collins and Montgomery, 2011).

Downstream of the bedrock canyons, the Carbon and the Puyallup Rivers have incised into Pleistocene glacial till for a short distance before joining near the city of Orting within the Puget Lowland, where the rivers' longitudinal profiles change (Collins and Montgomery, 2011). Following former embayments of Puget Sound (Booth, 1994), the slopes of lowland rivers decrease, promoting high sedimentation rates and long-term aggradation. From Orting to just downstream of the confluence with the White River, the Puyallup River flows down an elongated alluvial fan of coarse-grained sediment built during the Holocene predominantly by Mount Rainier sediment (Dragovich and others, 1994; Collins and Montgomery, 2011). Close to Commencement Bay, the Puyallup River flows across a flatter flood plain that Collins and Montgomery (2011) explained to be an alluvial reach where the river tends to have bed topography higher than the adjacent flood plain. Before development, these Puget Lowland rivers were prone to avulsions and active channel migration across the width of the flood plain.

When compared to profiles of other rivers draining Mount Rainier, the slope of the longitudinal profile of the White River is relatively modest (fig. 4B). Upstream of Mud Mountain Dam, the White River follows a structural feature in the Cascade Range that likely predates the volcano. Moreover, the White River was repeatedly impacted by lahars during the Holocene including the Osceola Mudflow, a large lahar that mobilized $3.8 \mathrm{~km}^{3}$ of sediment during a sector collapse of the volcano 5,600 years ago (Vallance and Scott, 1997). In addition to inundating the river corridor up to dozens of meters deep in flowing lahar, the event also rerouted the course of the White River from its early Holocene path, where South Prairie Creek now flows, to its current path through the glacial-till plain between Enumclaw and Auburn, Washington. Downstream of Auburn, the White River enters the former course of the Stuck River (from about WRKM 110 to the confluence with the Puyallup River), where slope decreases, fostering high sedimentation rates (Dunne, 1986; Prych, 1988; Czuba and others, 2010). The inset in figure 4A shows the pronounced reduction in slope of the White River along the former Stuck River about 7-10 km upstream of the confluence.

The Carbon River, upstream of its bedrock canyon, flows through an alluvial reach (fig. 4C). This alluvial reach has a relatively wide flood plain, and the slope of the Carbon River here is less than the geomorphically comparable section of the Puyallup River (fig. 4A). Most tributaries of the Carbon River enter at steep slopes likely reflecting the geomorphic response to Pleistocene alpine glaciation 
(Crandell and Miller, 1974). In contrast, South Prairie Creek enters the Carbon River at a slope much less than the main stem, reflecting the fact that this valley carried the White River before 5,600 years ago (Crandell, 1963).

The Nisqually River exhibits a long profile that grades into the reach of river where Alder Dam was constructed in 1945 (Czuba and others, 2012) (fig. 4D). Glacier-draining tributaries Kautz and Tahoma Creeks similarly grade into the main-stem Nisqually River, but tributaries draining catchments away from the volcano do not necessarily grade smoothly into the main stem, likely reflecting a smaller sediment supply or a delayed geomorphic response to changes in base level (Leopold and Bull, 1979) from Pleistocene alpine glaciation (Crandell and Miller, 1974). Curiously, Mineral Creek enters the Nisqually River with a supine slope, possibly reflecting a geologically recent episode of sedimentation along the main-stem Nisqually River. After entering the valley floor, Big Creek flows along a recent relict channel of the Nisqually River and exhibits little difference in slope relative to the main stem.

The Muddy Fork Cowlitz River steeply flows from the Cowlitz Glacier to the lower Cowlitz Valley in about $20 \mathrm{~km}$ (fig. 4E). As a result, much of the river corridor is bedrock controlled from the national park to Packwood, Washington, with a few alluvial reaches. The alluvial reaches closest to the volcano have a braided channel form indicative of some degree of sediment load, though these reaches are not as wide or as spatially extensive as braided sections of the Nisqually River or Carbon River. The Ohanapecosh River follows a similarly steep longitudinal profile from the glacier to its confluence with the main-stem Cowlitz River. If the Cowlitz River was aggrading with new sediment, the reach of river near Packwood, about $25 \mathrm{~km}$ downstream of the glacier where river slope decreases, would likely show aggradation. Czuba and others (2010), however, reported that the reach of the Cowlitz River near Packwood has been incised by about $0.5 \mathrm{~m}$ since 1990 . Though more research is needed to quantify sediment loads on the Cowlitz River system, observations indicate the Cowlitz and Ohanapecosh Rivers are not experiencing the same magnitude of rapid sedimentation documented on other rivers draining Mount Rainier.

\section{Sediment Equilibrium}

Where the Puyallup, Carbon, and White Rivers exit the mountain front and enter the shallow gradients of the Puget Lowland, long-term trends of aggradation and fill in former embayments of Puget Sound are prominent and widespread (Dragovich and others, 1994; Collins and Montgomery, 2011). In upstream mountainous reaches, however, aggradation is less pronounced and more localized.

Large lahars from Mount Rainier and a near-continuous supply of fluvial sediment between lahar episodes shaped the fluvial geomorphology of the White, Puyallup, and Nisqually Rivers. Most lahar episodes are marked in the geologic record by significant increases in sedimentation. In the Nisqually River flood plain, upstream of Alder Lake, Crandell (1971) documented a complex pattern of gravel- and sand-rich terraces of both lahar and fluvial origin that are likely associated with eruptive phases of the volcano. But the current upper Nisqually River is inset below these terraces indicating that the river has graded to a late-Holocene equilibrium, integrating long-term inputs of sediment from intereruptive periods and lahar episodes. Similarly, the White River flood plain contains an assemblage of lahar and fluvial terraces, the most prominent of which is the Osceola Mudflow (Vallance and Scott, 1997). Smaller but significant lahar episodes affected the White River valley between 2,600 and 2,200 years ago and between 1,500 and 1,000 years ago (Sisson and Vallance, 2008). Although late Pleistocene alpine glaciation likely scoured the White River valley near Mount Rainier, sediment supplied by lahar episodes refilled the White River valley toward a post-Pleistocene graded state that roughly balances current hydrology and sediment supply. The upper Puyallup River valley appears to still be under the influence of the 600-year-old Electron Mudflow (Scott and Vallance, 1995) that filled 
much of the flood-plain valley, constricting the current river with resistant lahar terraces and suppressing the formation of wide alluvial sections.

The perceived sediment-equilibrium conditions in the White and Puyallup Rivers, as well as in the Nisqually River, contrast with documented disequilibrium conditions between sediment yields from Cascade Range drainages in British Columbia, Canada (Church and Slaymaker, 1989). The upper Carbon River, however, may still reflect the influence of Pleistocene alpine glaciation. The Carbon River, upstream of its bedrock canyon reach (upstream of CRKM 27), flows through a wide alluvial reach with few topographically high terraces. Few large lahars have impacted the Carbon River during the Holocene (Crandell, 1971; Scott and others, 1995), and the relatively wide alluvial flood plain coupled with the lack of high constraining terraces may indicate that the upper Carbon River valley is still adjusting its sediment load to a river valley carved by Pleistocene alpine glaciers.

\section{Bed-Material Sediment Size}

Czuba and others (2010) reported characteristic bed-material size along the Puyallup, Carbon, and White Rivers within the Puget Lowland (fig. 5). The beds of these lowland rivers contained predominantly sand, gravels, and cobbles, though boulders made up a portion of the bed for the Puyallup and Carbon Rivers, where the rivers exit the mountain front and first enter the lowland. A gravel-sand transition was present in the Puyallup River approximately $6.4 \mathrm{~km}$ (PRKM 76.1) from the river mouth at Commencement Bay. A similar gravel-sand transition was found on the White River approximately $5.6 \mathrm{~km}$ (WRKM 111.1) upstream of the confluence with the Puyallup River.

For this study, using the Wolman pebble-count method (Wolman, 1954), bed-material size was measured along the main stems of the Puyallup, Carbon, White, and upper Nisqually Rivers into Mount Rainier National Park. For the pebble-count method, a 30-m tape measure was laid along the apex of gravel bars, and particles were counted every $0.3 \mathrm{~m}$ (100 particles counted for each survey), with all particles less than $2 \mathrm{~mm}$ grouped into the sand category. At each measurement site, at least three surveys were made and the combined data defined the grain-size distribution.

Boulder- to cobble-sized material was present in all main-stem river reaches within Mount Rainier National Park (fig. 5). As much as one-quarter of the bed material in the Nisqually and Carbon Rivers within $3 \mathrm{~km}$ of the glacier terminus was boulder sized. Boulder-sized material also was widespread along the upper Puyallup River. The White River upstream of Mud Mountain Dam had fewer boulders than the Puyallup and Carbon Rivers. Gravel-sized particles were present in all river reaches except the most downstream sections of the lower Puyallup and lower White Rivers where sand is dominant. Downstream of the national park boundary, the upper Puyallup and Carbon Rivers had larger bed-material sediment than the Nisqually and White Rivers at similar distances from the mountain (fig. 5). This difference may reflect greater sediment loads coming from the Nisqually and White Rivers relative to the Puyallup and Carbon Rivers, as pulses of sediment translating through a river corridor have particle-size distributions smaller than the extant bed (Lisle, 2008).

The percentage of sand in the bed material can indicate sediment surplus conditions and also is an important parameter to assess bedload-transport potential. Sand percentage of the bed was mapped for each river of interest (fig. 6). Sand was prevalent throughout the river network, and there was widespread sand on the upper Nisqually River and upper White River. The upper Carbon River also had a large percentage of sand. Although sand was present along the upper Puyallup River, the relative percentage was less than the percentage of sand on other rivers. Similarly, the White River downstream of the West Fork White River and upstream of Mud Mountain Dam had a relatively small percentage of sand, possibly reflecting larger hydrologic transport capacity of the White River downstream of the West Fork White River. 
The particle size coarser than 90 percent of the particles at a site (D90) also was mapped showing the relatively large D90 values near Mount Rainier and general trends of fining in the downstream direction (fig. 6). However, D90 sizes remained relatively large along the White, Carbon, and Puyallup Rivers several kilometers downstream of the mountain front, reflecting large stream power and significant transport potential well into the lowland reaches.

\section{Hydrologic Trends and Geomorphic Response at Gaging Stations}

The hydrologic flow regime of the Mount Rainier watershed governs the transport capacity of the river network. Data from streamflow-gaging stations on Mount Rainier rivers (table 1) were analyzed to assess trends in hydrologic flow regime, specifically trends in runoff as well as trends in peak-flow events. Data were also analyzed to determine if geomorphic responses of aggradation and incision at a particular gaging station could be correlated with hydrogeomorphic conditions of individual storms affecting a particular catchment.

\section{Analyzing Hydrologic Gage Data}

Daily discharge values recorded at the Puyallup River at Puyallup gage (12101500) and on the upper Cowlitz River at Packwood gage (14226500) were used to analyze general long-term flow conditions of rivers draining Mount Rainier. The gaging record for the Nisqually River near National (12082500), which drains the southern flank of Mount Rainier, began in 1942 and indicates that runoff trends in the Nisqually River were similar to general trends for the Puyallup and Cowlitz Rivers.

Long-term daily-discharge values were examined for correlation with trends in the Pacific Decadal Oscillation (PDO). The PDO is a sea-surface temperature pattern that develops in the northern Pacific Ocean and typically persists for 20-30 years (Mantua and others, 1997). The PDO index, produced and made available by the Joint Institute for the Study of the Atmosphere and Ocean (University of Washington, 2012), is a metric representing the monthly sea-surface temperature. A positive PDO index indicates warmer than normal sea-surface temperatures in the northern Pacific Ocean, and a negative PDO index indicates cooler than normal temperatures. The El Niño-Southern Oscillation (ENSO), a large-scale climate pattern of sea-surface temperatures in the tropical Pacific Ocean that typically cycles every 5 years, also influences precipitation and runoff in the Pacific Northwest (Redmond and Koch, 1991; McCabe and Dettinger, 1999); however, averaged over decades, the PDO largely reflects the influence of ENSO forcing (Newman and others, 2003). Because the PDO more strongly influences winter precipitation in the Pacific Northwest than the ENSO alone (McCabe and Dettinger, 2002), only correlations between runoff and the PDO index were considered here, but future studies can more fully assess teleconnections between runoff, PDO, and ENSO.

Peak-flow events for unregulated river reaches were analyzed to assess long-term trends and identify periods of time with several large events. A Mann-Kendall trend test on the peak-flow magnitude, where time is the dependent variable, was conducted to determine if statistically significant peak-flow trends were detectable, where a $p$-value less than 0.05 indicates there was a statistically significant trend with time (Helsel and Hirsch, 1992).

\section{Long-Term Hydrologic Runoff}

The 10-year moving average of daily discharge recorded at the lower Puyallup River and the Cowlitz River, normalized against the long-term mean annual flow, showed the general hydrologic runoff trends of the two rivers through the 20th century (fig. 7). Flood-management actions at Mud Mountain Dam do not affect the 10-year moving average of discharge in the lower Puyallup River 
because water is not retained in the reservoir for extended periods. Diversions and returns to and from Lake Tapps affected summer flows in the lower Puyallup River to some extent during the 20th century (Herrera Environmental Consultants, 2005), but for the purposes of this study, it is assumed that these effects are small compared to the 10-year average of total runoff. The Cowlitz River near Packwood is unregulated. Distinct wet and dry hydrologic periods appeared in the flow record with the period of time from 1911 to 1947 having normal or below normal flows; the period from 1947 to 1978 representing a wet hydrologic period; and the period from 1978 to about 1994 representing another dry hydrologic period. From the middle 1990s to about 2005, runoff was normal. Since about 2005, runoff appears to have increased.

Comparing the hydrologic flow conditions of the Puyallup and Cowlitz Rivers against the PDO index plotted on a scale, with positive and negative values reversed from the usual convention, shows a relation (fig. 7). Analysis of the data indicated that the coefficient of determination $\left(\mathrm{R}^{2}\right)$ between runoff and the PDO index was about 0.65 . Researchers have identified a distinct 20th-century cool period from 1947 to 1976 in the PDO index (Mantua and others, 1997), which corresponds to a period of greater runoff in Mount Rainier rivers. In contrast, researchers also identified two prominent 20th-century warm periods in the PDO from 1925 to 1946 and from 1977 to at least the middle 1990s. The runoff of the Puyallup and Cowlitz Rivers during these periods was smaller than normal. It appears that the PDO influences the general hydrologic runoff of rivers draining Mount Rainier and that cool PDO phases will result in the potential for larger overall runoff.

\section{Peak-Flow Events}

Mass and others (2011) argued that large rain events have increased in catchments along the Washington coast. But Mass and others (2011) and Wallick and others (2011) also observed decreasing trends in flood magnitude in Oregon and northern California. In analysis of long-term streamflowgaging data, Hirsch and Ryberg (2011) found no statistically significant correlation between peak flows in the northwestern quadrant of the United States and the magnitude of global atmospheric carbon.

Plotting the annual peak flow for the available record on the unregulated sections of the Puyallup, Carbon, Cowlitz, and Nisqually Rivers reaffirms observations (Pierce County, 2012) that several large floods have affected the region since about 1990 (fig. 8). Large floods in western Washington are caused predominantly by atmospheric rivers (Neiman and others, 2011), which tend to affect geographically limited regions. Because the positional focus of any given atmospheric river can shift due to subtle differences in atmospheric steering winds, whether or not Mount Rainier is affected by a strong atmospheric river from one year to the next appears to be governed by stochastic probabilities. Though possible that the PDO might influence the strength of atmospheric rivers, the data set from Mount Rainier gages is too limited to detect a direct correlation.

A more fundamental question posed by Allan (2011) and Min and others (2011) is whether precipitation events will become more severe with global climate change. The data from the Nisqually River near National has been identified as an example of an increasing trend in peak flows. Applying the Mann-Kendall trend test to the Nisqually River data resulted in a $p$-value of 0.014 , confirming that for WYs 1942-2011, annual peak flows increased along the upper Nisqually River. Applying the MannKendall test to longer streamflow records from the Cowlitz, Carbon, and upper Puyallup Rivers, however, resulted in $p$-values of $0.067,0.067$, and 0.512 , respectively, indicating there are no statistically significant trends of increasing peak flows for these rivers. Regionally, the 1930s were a period of large floods. The Nisqually River gaging station began operation in 1942 and the streamflow data record does not capture the larger peak flows of the early 20th century, likely explaining the contrast in results of trend analysis compared to the other gages. Considering the available peak-flow 
data from unregulated Mount Rainier gages and the possibility that increasing trends verified on the Nisqually River may be an artifact of a short gaging record, the data indicate that there has not been a statistically significant trend of increasing peak flows during the 20th century in the rivers draining Mount Rainier.

\section{Implications of 20th-Century Hydrology on Sediment Production and Transport}

Based on runoff and peak-flow data, time periods in the gaging record were categorized into more-active or less-active periods (in hydrological terms) to provide context for later discussion of sediment-load and sediment-production analyses. The period of time from the late 1940s to about 1960 had great-than-normal runoff (fig. 7) and some large peak-flow events (fig. 8). This period was more active hydrologically. The notable 1947 Kautz debris flow (Crandell, 1971) contributed significant sediment to the main-stem Nisqually River; this sediment was transported to Alder Lake during the 1950s (Czuba and others, 2012). In contrast, conditions were less active from the middle 1960s to the middle 1970s, a period with slightly greater-than-normal runoff but few large peak-flow events to produce new sediment from the catchment. Conditions became even less active from 1978 to about 1994, when hydrologic runoff was less than normal and there were few peak flows. Large peak flows started to affect the region again in the 1990s, with the February 1996 flood ushering in a more active period. Recently, increased hydrologic activity occurred from 2006 to 2009 with the combination of greater-than-normal runoff and large peak-flow events (Beason and Kennard, 2007; Mastin and others, 2010).

\section{Geomorphic Response to Hydrologic Events}

Flood-induced incision or aggradation of a particular river reach is governed by the mass balance of sediment entering and exiting the reach and the resulting storage of bed material. Using gage analysis, Czuba and others (2010) found the Nisqually River near National had experienced significant changes in the stage-discharge relation since 1942. Plotting stage for the median flow for the Nisqually River along with the daily discharge from 1986 to 2011 showed an apparent relation between stage changes recorded at the gage and during peak flow events (fig. 9). During some large peak-flow events (notably, the February 1996 storm), the median-flow stage at the gaging station decreased significantly. In contrast, other peak-flow events (for example, during the November 2006 storm) were associated with a net increase in median-flow stage at the gage. Still other peak-flow events were associated with little or no change in median-flow stage.

To assess what may influence the geomorphic response at the Nisqually River gage, individual shifts in stage for the 20 largest peak flows from 1989 to 2009 (table 2) were compared to 81 atmospheric, hydrologic, and meteorological data sets collected in the catchment before, during, and after the particular flood event. Flows occurring from April to October, likely representing snowmelt events, were excluded. Peak-flow date and time were determined using the maximum unit-discharge value that occurred during the storm period. The change in stage at the gaging station related to a particular peak-flow event was calculated by subtracting the stage at median flow at the gaging station before and after the event (Czuba and others, 2010).

Changes in stage at the Nisqually River gage were compared to National Oceanic and Atmospheric Administration atmospheric-sounding data from the Quillayute, Washington (University of Wyoming, 2011), before and during the peak event. Sounding parameters, including precipitable water, wind, temperature, pressure, and indices of instability (table 3 ) were compared to observed changes in stage. Changes in stage were also compared to snowpack telemetry (SNOTEL) data from Paradise, Washington (National Resources Conservation Service, 2011). SNOTEL data included the 
snow-water equivalent and air temperature before, during, and after the peak-flow event. Finally, stage changes also were compared to Longmire, Washington, and Paradise weather-station data from the National Climatic Data Center (CLIMATEDATA disk Volume 21.3 and 20.2, 2010, produced by EarthInfo ${ }^{\circledR}$, Inc.), which included precipitation. Sounding data for the 48 hours preceding the peak flow were compiled and analyzed. Of the available SNOTEL sites, the Paradise site was the closest to the Nisqually River gage and was centrally located within the upper catchment. Similarly, daily rainfall data measured at weather stations at Longmire and Paradise within the upper Nisqually River catchment were analyzed. In all, 81 parameters were available in sufficient quantities to test for correlation (table $3)$.

Of the 81 parameters evaluated, only 4 parameters had a coefficient of determination $\left(\mathrm{R}^{2}\right)$ larger than 0.20 (indicated in bold in table 3 ), signifying little correlation between parameters and measured changes in river stage. Even for the four parameters with a coefficient of determination larger than 0.20, the correlation between the parameter and stage change was weak. The strongest correlation was between minimum temperature one day after the peak and stage change $\left(\mathrm{R}^{2}=0.56\right)$, and two other postevent temperature parameters also showed a weak correlation (average temperature and maximum temperature the day after the peak). Of the evaluated data parameters from the day of the storm, only the sounding-recorded severe weather threat (SWEAT) index (a stability index which incorporates instability, wind shear, and wind speed; National Oceanic and Atmospheric Administration, 2012) showed a weak correlation to stage change $\left(R^{2}=0.29\right)$. Notably, several parameters which were anticipated to correlate with gage response, including total precipitation, precipitation intensity, antecedent moisture conditions, and snow-water equivalent in the watershed, were found to have no correlation.

The failure of the exercise to find even reasonably moderate correlations with hydrologic or atmospheric parameters may be due to the time delay between a particular hydrologic perturbation and the response measured at the Nisqually River gage. The Nisqually River gage is about $14 \mathrm{~km}$ downstream of the national park boundary and $32 \mathrm{~km}$ downstream of the Nisqually Glacier. Even for a large flood, the sediment mobilized from the within the watershed likely would be deposited in the main stem upstream of the gage and require a series of additional peak-flow events to transport to the river reach near the gage. A gage location closer to the disturbed section of the catchment or a compensation for a time delay in the movement of sediment likely would be needed to find a better correlation between hydrologic parameters and gage response. The lack of correlation in the analysis may also be related to the fact that stage at a given gage, which is related to the hydraulic control in the river just downstream from the gage, may not exclusively reflect sediment conditions in the watershed. Instead, hydraulic control could be affected by other factors including vegetation, wood assemblages, or localized sediment accumulation not associated with conditions in the watershed.

\section{Sediment Loads of Mount Rainier Rivers}

Knowledge of sediment loads in regional rivers is important to a wide spectrum of resource managers dealing with aquatic habitat, flood-hazard management, and planning issues (see Herrera Environmental Consultants, 2010; Pierce County, 2012). For flood-risk management along Mount Rainier rivers, bedload data are most useful, but knowledge of suspended-sediment load also is helpful because of impacts on water quality and aquatic habitat as well as the fact that bedload is typically 4-10 percent of suspended-sediment load (Nelson, 1971; Nelson, 1974). Suspended-sediment load data, being easier to collect, are more readily available. Furthermore, determining the source of sediment within the catchment is important to help guide planning and river-management responses to current and future sedimentation trends (Dietrich and others, 1982; Reid and Dunne, 1996). 
Owing to ample supply from Mount Rainier, sediment loads in the Puyallup and upper Nisqually Rivers are large relative to other rivers in western Washington (Czuba and others, 2011). The Skagit and Nooksack Rivers, draining the stratovolcanoes Glacier Peak and Mount Baker, respectively, also have large sediment-discharge values (Czuba and others, 2011). However, data sets characterizing sediment load in western Washington rivers are limited, particularly given the large temporal variability in loads. Order of magnitude changes in sediment load from one year to the next are common in most river systems (Horowitz; 2003; Milliman and Farnsworth, 2011), and limited studies from Washington show that rivers draining Mount Rainier have similar degrees of variability (Nelson, 1974, 1978; Dunne, 1986). Ideally, sediment load would be measured continuously for many years to quantify the total load from the system and to identify trends (for example, Horowitz, 2010). No long-term sediment-discharge data are available for rivers in western Washington, and those data that are available typically represent one to five discontinuous years from the 1960s to 2000s (Czuba and others, 2011).

Several approaches were applied in this study to help evaluate the magnitude of sediment load from rivers draining Mount Rainier and determine the source of sediment from within the catchment. Published studies of sediment loads and unpublished historical USGS sediment data within the Mount Rainier watershed and along regional rivers were collected as part of a literature review. Trends in active-channel width of rivers and streams draining glaciers on Mount Rainier were evaluated using aerial images and LiDAR DEMs. Coarse estimates of sediment-production potential from subcatchments were generated for the mountainous, forested portion of the Puyallup River basin (including the White and Carbon Rivers) and the upper Nisqually River outside the boundary of Mount Rainier National Park. Data from complementary USGS cooperative studies were used to determine recent sediment loads along the lower White River. Hundreds of historical USGS data records, mostly collected from the 1970s to the 1990s, were assembled and analyzed to determine the magnitude of suspended-sediment load and bedload and to assess seasonality of rivers draining Mount Rainier. Finally, these multiple data sets and analyses were synthesized to estimate current sediment loads of rivers within the study area, determine sources of sediments within the catchment, and assess trends in sediment production from Mount Rainier since 1990.

Although aerial imagery and local field observations suggest some small proportion of the sediment load exiting the park originates from mountainous areas away from the stratovolcano, no effort was made to differentiate the sources of sediment within the boundaries of Mount Rainier National Park. For the purposes of this study, reference to Mount Rainier generated sediment applies to sediment sourced from the locations inside the administrative boundary of Mount Rainier National Park.

\section{Previous Sediment-Load Estimates}

Published sediment-load and yield measurements from rivers draining Mount Rainier, contributing drainages, and other rivers and basins in the coastal Pacific Northwest were assembled to assess known sediment production from Mount Rainier and to compare sediment production between catchments (table 4). Researchers have generated sediment-load estimates using different methods including measurements from the river (Fahnestock, 1963; Nelson, 1974, 1978; Wise and others, 2007); measurements of sedimentation in a basin (Walder and Driedger, 1994); calculations based on existing data sets (Mills, 1976; Downing, 1983; Dunne, 1986; Abbe and others, 2007); calculations based on empirical models (Herrera Environmental Consultants, 2010); and calculations of catchment-based sediment budgets (Laurie, 2002; Ketcheson and others, 2003). In analyzing the regional data, sediment yield (sediment load normalized by drainage area) allows a comparison between basins.

Within the White River basin, Dunne's (1986) estimate of 450,000 tonnes/yr of total sediment load in the reach upstream of Mud Mountain Dam likely is the best available estimate, because it builds 
on the work of Nelson (1978) who collected more than 700 sediment measurements between June 1974 and June 1976. Nelson reported a total load of 390,000 tonnes in the first year of the study and 1.3 million tonnes in the second year, reflecting the temporal variability of sediment load within the system. Dunne (1986) used hydrologic data extended to 1966 to refine the overall load estimate, but reiterated the variability in the system. Dunne's estimate also spans a time period of less-active hydrogeomorphic conditions, with smaller than normal sediment loads. The sediment-load data of the White River near Emmons Glacier of Fahnestock (1963) were collected only during the summer, potentially missing important sediment transport occurring in autumn and winter. The other estimates of sediment load from the White River basin were based on sediment budgets of smaller catchments in the basin and were larger than Dunne's calculations.

Few sediment-load estimates are available for the lower Puyallup River, though Wise and others (2007) reported that the sediment load in 2000 was 1,250,000 tonnes. Downing's (1983) estimate of total load on the lower Puyallup River was significantly smaller. Czuba and others (2011) synthesized the results of Wise and others (2007) and Downing (1983) to report a total load in the Puyallup River at Puget Sound of 890,000 tonnes/yr, but the precision of this number is poor owing to the limited data.

Within the greater Mount Rainier basin, Nelson (1974) published the most complete and extensive study of sediment loads, measuring suspended-sediment concentration from 1971 to 1972 at 16 sites in the Nisqually and Deschutes River basins. Using multi-year hydrologic data, Nelson estimated suspended-sediment load for each site. Nelson's load estimates do not include bedload, but Nelson assumed bedload was less than 10 percent of the total load. Within the study area, Nelson's (1974) estimates for the Nisqually River near National and for Mineral Creek near Mineral showed about an order of magnitude decrease in sediment yield for drainages away from the volcano (table 4). Nelson's (1974) data also were collected in a hydrologically quiet period with relatively few large, sediment-producing storms, and likely underestimates long-term sediment loads. Mills (1976) used bathymetric data to estimate sediment load of the Nisqually River into Alder Lake of 902,000 tonnes/yr. Czuba and others (2012) later refined Mills' estimate of sediment filling Alder Lake and extended the bathymetric record to 2011. Load estimates for the upper Nisqually River for this study, based on the data collected by Czuba and others (2012), are discussed later in this section. Owing to the episodic nature of sediment transport in Mount Rainier basins, generating a long-term sediment-load estimate for the Nisqually River from Alder Lake sediment volumes is more accurate than other methods because the largest sediment events are captured in the record. The Nisqually River basin, in particular, has been subject to significant sediment inputs from the volcano that have been well documented (Crandell, 1971; Walder and Driedger, 1994; Beason, 2007).

The largest sediment yield values are found on rivers and tributaries close to Mount Rainier where loads are large and the contributing basin area is small. For example, Tahoma Creek had a sediment yield of 14,000 (tonnes/ $\mathrm{km}^{2}$ )/yr and the White River, just downstream of Emmons Glacier, had a yield of 12,000 (tonnes $/ \mathrm{km}^{2}$ ) $/ \mathrm{yr}$. In river reaches downstream of the park boundary, sediment yields on rivers draining the glaciated volcano tend to be on the order of about $1,000\left(\right.$ tonnes $\left./ \mathrm{km}^{2}\right) / \mathrm{yr}$. Sediment yields from mountainous catchments not draining Mount Rainier tend to be about 100 (tonnes $\left./ \mathrm{km}^{2}\right) / \mathrm{yr}$. Sediment yields from catchments in the Puget Lowland tend to be on the order of 10 (tonnes $\left./ \mathrm{km}^{2}\right) / \mathrm{yr}$.

Data from Milliman and Farnsworth (2011) for rivers draining coastal mountainous regions of the Pacific Northwest were analyzed to place the sediment-load and sediment-yield estimates from this study into a regional context. In general, coastal Pacific Northwest rivers have sediment yields between 100 and 500 (tonnes $/ \mathrm{km}^{2}$ )/yr, though some rivers have yields more than 1,000 (tonnes $/ \mathrm{km}^{2}$ ) $/ \mathrm{yr}$. Rivers in coastal British Columbia, Canada, also tend to have large sediment yields (table 4). 


\section{Historical Changes in Plan Form and Profiles in Mountainous River Reaches}

The active-channel widths of mountainous reaches of rivers draining Mount Rainier were determined from aerial imagery from 1965, 1994, and 2009 to identify temporal and spatial changes in the width of the active channel. The difference between active-channel widths between 1965 and 1994 and between 1994 and 2009 provided an estimate of the lateral expansion and contraction of the active channel resulting from hydrogeomorphic disturbance of the catchment (such as debris flows and floods) and vegetation encroachment, respectively. Along main-stem rivers, the mean elevation of the active channel was compared to the mean elevation of the first forested terrace adjacent the active channel to assess the qualitative degree of channel filling within particular reaches. Historical river-elevation profiles from 1910 and from the 1950s to 1990s were compared to current river elevations with the goal of identifying regions of changing channel storage through aggradation or incision. The uncertainty of the historical contours was greater than most of the computed changes in elevation. To get a gross estimate of sediment contributions to the active channel from the flood plain owing to channel widening, the change in active channel width was multiplied by forested terrace height.

\section{Change in Active-Channel Width for Rivers Draining Mount Rainier}

Paper copies of 1965 black and white aerial photographs of Mount Rainier and the surrounding landscape from the University of Washington library were scanned, imported into ArcGIS®, and georeferenced to the 2009 imagery using common features (for example, roads, structures, islands, and lakes). Features closest to the river corridor, rather than the surrounding landscape, were used for georeferencing to ensure the greatest accuracy of the river features. Georeferenced aerial imagery for 1994 was obtained from digital orthophoto quadrangles (DOQs; U.S. Geological Survey, 2012a) and for 2009 from the National Agricultural Imagery Program (NAIP; U.S. Department of Agriculture, 2011). In some instances, imagery was not available for the entire river course in 1965 and 1994.

Digitization of the imagery was completed at a scale of 1:3,000. The active channel, defined as the section of the river corridor relatively free of vegetation that conveys most of the water and sediment during high flow, was digitized for each of the three sets of aerial images. Areas of dense vegetation within the bounds of the active channel were digitized as island features and did not count towards active-channel width. Each digitized data set was reviewed for quality, accuracy, and consistency following the recommendations of Wallick and others (2011). A river centerline was then digitized through the approximate center of the active channel, representing the dominant pathway of the river during high flow. For every 1-km length along the 2009 centerline, the average active-channel width for each of the three imagery sets $(1965,1994$, and 2009) was computed by dividing the active-channel area by the length of the segment of channel centerline for that year. Resolution of the 1994 imagery was 2 meters, and resolution of the 2009 imagery was 1 meter. Resolution of the georeferenced 1965 imagery was not measured but likely was about $10 \mathrm{~m}$. In comparing changes in channel width between imagery sets, differences greater than $25 \mathrm{~m}$ were assumed to be significant.

The rivers included in the active-channel width analysis (table 5) are shown in figure 10 along with the values of the 2009 active-channel width averaged over 1-km segments. In general, only the mountainous reaches of study rivers closest to Mount Rainier, where changes to active-channel width are prominent and where bank armoring is rare, were analyzed. The active-channel widths were averaged over various sub-reaches and summarized in figure 11. Of the river reaches analyzed, the Nisqually and Carbon Rivers had the widest active channels. The White River upstream of the Mount Rainier National Park boundary and the West Fork White River downstream of the national park boundary also showed wide active-channel widths. The active-channel widths of the Puyallup and 
Cowlitz Rivers and their tributaries generally were smaller, except for the Mowich River and the Cowlitz River downstream of the Muddy Fork Cowlitz River.

The change in active-channel width between 1965 and 1994, averaged by 1-km reaches (fig. 12), suggests that this period was relatively free of hydrogeomorphic events capable of disturbing the active channel. The exception is Tahoma Creek, where the active-channel width increased by more than 175 $\mathrm{m}$. This change is consistent with the record of known debris flows on Mount Rainier, as 1967 was the beginning of a series of debris flows on Tahoma Creek (Copeland, 2009). During this time period, Kautz Creek was recovering from the 1947 debris flow, evidenced by the decrease in active-channel width by more than $100 \mathrm{~m}$ and the growth of vegetation.

The change in active-channel width between 1994 and 2009 (fig. 13) suggests that this was a period when the catchment was subjected to greater hydrogeomorphic disturbance, including debris flows, large floods, and increased sediment transport, resulting in increases in active-channel width of over $25 \mathrm{~m}$ on many rivers and tributaries downstream of the volcano. The largest increases in activechannel width during this time period were on the Carbon and Nisqually Rivers. The upper Carbon River near the glacier increased in active-channel width by more than $100 \mathrm{~m}$. Significant active-channel widening on the Carbon River also occurred downstream of CRKM 10 with more than $100 \mathrm{~m}$ of increase in an alluvial section of the river near CRKM 24. The Nisqually River, downstream of Kautz Creek, widened along most of its length by up to $200 \mathrm{~m}$. Channel widening was particularly pronounced between NRKM 20 and 30. The Nisqually River was subjected to two large peak-flow events in 1996 and 2006, which caused significant geomorphic change (Beason and Kennard, 2007; Pierce County, 2012), and to a significant source of new sediment into the river network from debris-flow activity (Copeland, 2009). Along the White River, increases in active-channel width occurred, but the magnitude of change was more modest than changes observed on the Nisqually and Carbon Rivers. Increases in active-channel width of 25-50 m were apparent along much of the main-stem White River and the West Fork White River. The Puyallup River system also increased in channel width, particularly along the main stem up to the Puyallup Glacier and along the Mowich River, although the changes here were less than changes along the White River. Notably, the South Fork Puyallup River had no detectable changes in active-channel width dating back to 1965. The Muddy Fork Cowlitz River experienced limited increases in active-channel width, but much of this river flows through a bedrockcontrolled canyon and the channel likely would not respond as dramatically to increases in sediment load as other rivers. Similarly, the Ohanapecosh River is bedrock controlled, but the few alluvial reaches of the Ohanapecosh River showed little or no expansion. In general, the limited channel-width expansion from rivers draining the eastern flank of Mount Rainier, compared to trends along the Nisqually, White, and Carbon Rivers, suggests smaller increases in sediment production since 1994.

Of the rivers draining Mount Rainier glaciers, all but the Muddy Fork Cowlitz and the Ohanapecosh Rivers, which both flow through some length of bedrock control, have long alluvial deposition zones just downstream of the glacier. Assuming that the underlying hydrology of each of the draining streams is similar (a reasonable assumption given the mountain is a stratovolcano mostly symmetric around its vertical axis), then active-channel width can be considered a proxy for recent trends in geomorphic disturbance and sediment load. Increases in channel width are often associated with aggradation (Lyons and Beschta, 1983; Madej and Ozaki, 1996; Lisle, 2008; Pierson and others, 2011) and increased bedload (Leopold and Maddock, 1953). In addition, for mountain rivers, large width-to-depth ratios and braiding are indicative of significant bedload (Schumm, 1977). Although increases in channel width can also reflect geomorphic disturbance of large floods that remove riparian vegetation, particularly in logged river corridors (see Lyons and Beschta, 1983), the old-growth forests within Mount Rainier National Park effectively resist avulsions and channel widening (Kennard and 
others, 2011). In general, alluvial river reaches with wider active channels are assumed to transport more bedload than rivers with narrower active channels, a concept shown in theory (Parker and others, 2007) and applied in practice (Lauer and others, 2008).

Active-channel width for the White, West Fork White, Carbon, Puyallup, and Nisqually Rivers did not increase appreciably after these rivers exited Mount Rainier National Park. The Cowlitz River near Packwood showed a large active-channel width in 2009, but comparative imagery from 1994 or 1965 was not analyzed as part of this study precluding an assessment of change through time. However, Collins and others (2012) attributed the wide active channel of the Cowlitz River to logging in and near the flood plain. Based on qualitative assessment of available imagery, tributaries entering the main stems of the four study rivers originating from logged mountainous catchments not draining Mount Rainier did not have noticeably wide active-channel widths. This suggests, qualitatively, that the predominant source of sediment to the river networks is Mount Rainier.

\section{Active-Channel Elevation Relative to Forested-Terrace Elevation}

Comparison of mean elevation of the active channel to the mean elevation of the first forested terrace adjacent the active channel was evaluated only where the terrace had continuously supported a forest since 1965 (based on aerial imagery). For each analyzed location, a cross-section line was created in ArcGIS orthogonal to the channel flow direction and spanning the terrace and active channel. Elevation data were extracted every $4 \mathrm{~m}$ along the cross section in both the active channel and forested terrace, and no elevation data were taken from a $20-\mathrm{m}$ buffer at the margin between the active channel and the forested terrace. For all cross sections, at least 10 individual elevation points were included in the calculation of mean elevation. All elevation data were extracted from LiDAR-based DEMs (appendix A, table A1). Although the absolute accuracy of the LiDAR DEMs was about $1 \mathrm{~m}$, relative local differences in the elevation along a cross section of $0.5 \mathrm{~m}$ or greater likely were detectable. Because the forested terraces contained some volume of accumulated organic material on the ground, elevation estimates from the forest likely were higher than the bare ground. The average elevation along the cross section from the active channel, defined using the 2009 active-channel centerline digitization, was subtracted from average elevation of the forested terrace to compute the terrace elevation. Positive terrace-elevation values indicate the forested terrace was higher than the active channel (fig. 14). Negative terrace-elevation values indicate the active channel was above the forested terrace.

The terrace elevations of the Carbon River in 2009 were 1-2 m for most of its length (fig. 14A) and lower than terrace elevations measured along the Nisqually and Puyallup Rivers, suggesting that the braided Carbon River was in a state of aggradation likely associated with more-active hydrogeomorphic conditions prevalent since 1996. The Nisqually River from NRKM 8-12 was less than $1 \mathrm{~m}$ below the forested terrace indicating recent aggradation and confirming observations by the National Park Service (Beason and Kennard, 2007). The farthest upstream extent of the Nisqually River had elevated terraces on the order of $10 \mathrm{~m}$. This section of the river flows through large, prominent fluvial terraces deposited during eruptive periods (Crandell, 1971), confirming that contemporary sediment loads in the Nisqually River are significantly smaller than sediment loads typical during eruptive phases. Downstream of Kautz Creek, the terrace elevation of the Nisqually River generally was between 1 and $3 \mathrm{~m}$. Compared to the other rivers analyzed, terrace elevations of the Puyallup River were larger, generally between 3 and $6 \mathrm{~m}$ (fig. 14C). The larger terrace elevations likely were due to smaller sediment loads in the Puyallup River (as assessed using active-channel width in 2009) and by the presence of the Electron Mudflow, which constricted the upper Puyallup River flood plain and increased transport capacity. The White River between WRKM 8 and 18 had an active-channel elevation essentially even with the forested-terrace elevation. A number of cross sections in this reach had channel elevations above the 
forested terrace. These data support the observation of Kennard and others (2011) describing severe aggradation and the role of old-growth forest to maintain channel position during periods of increased sedimentation. Downstream of the national park boundary, the terrace elevation of the White River was more typical of terrace elevations observed along the Nisqually River, but possible areas of aggradation were observed near WRKM 30 and 50.

\section{Change in Elevation of River Profiles}

Historical river-elevation profiles were compared to current river-elevation profiles with the goal of identifying regions of changing channel storage through aggradation or incision. Historical data sets that were analyzed included a 1910 survey of river corridors from a water power study (Henshaw and Parker, 1913) and USGS topographic quadrangles digital raster graphics (DRGs) from the 1950s to 1990s (U.S. Geological Survey, 2012a). The 1910 survey was available as paper maps with outlines of the channel and elevation contours drawn at 1.5-m intervals above mean sea level (Henshaw and Parker, 1913). The paper maps were scanned and georeferenced to the North American Datum of 1929 (NAD29, horizontal). Channel outlines and contour lines were then digitized in ArcGIS from the rectified maps and attributed with contour elevations assuming that the vertical datum of mean sea level of the historical contours was equivalent to NGVD29. The contours were then projected and converted to the North American Datum of 1983 (NAD83, horizontal) and the North American Vertical Datum of 1988 (NAVD88; vertical) in meters. The 2.5-m resolution USGS 1:24,000 topographic quadrangles digital raster graphics (DRGs) from the 1950s to 1990s (U.S. Geological Survey, 2012a) were available as individual tiles with 6- or 12-m elevation contours. Channel centerlines and contours near the rivers were digitized from the maps and projected and converted to NAD83 and NAVD88 in meters. The uncertainty of the historical contours was much greater than most of the computed changes in elevation. Therefore, the results from this analysis were not used and are not discussed further.

\section{Sediment Contributions from the Flood Plain due to Expansion of the Active Channel}

Sediment budgets in fluvial systems sometimes consider contributions from channel widening or avulsions (Trimble, 1999; Lauer and Parker, 2008) when knowledge of short-term or localized sediment responses is important. Over longer (geologic) time scales, however, these calculations often are discounted because fluvial sediment recruited from the flood plain is not new sediment to the system, instead it is fluvial sediment exiting or entering temporary storage. For some river reaches in the study area, knowledge of the local recruitment of sediment is useful for river-management decisions. To estimate sediment released from the flood plain owing to recent channel widening, changes in activechannel width are needed along with channel- and bank-elevation data before and after the time period of interest. For mountainous reaches of main-stem rivers draining Mount Rainier studied here, the changes in active-channel width between 1965 and 1994 and between 1994 and 2009 were known, and the topography of the braided channel and first forested terrace in 2009 was determined using LiDAR data. Pre-change topography of the river corridor in either 1965 or 1994, however, was unavailable. Because of the lack of pre-change elevation data, the analysis included here does not represent a calculation of sediment exchange with the flood plain. Additionally, the analysis here does not account for sediment contributions from river migration into bluffs of glacial till that bound river flood plains in the Puget Lowland. Recruitment of sediment from glacial-till bluffs can be significant. Rather, this analysis approximates the order of magnitude of sediment volume potentially released from the flood plain due to channel widening. The analysis only considers main-stem, alluvial reaches of the Nisqually, Puyallup, Carbon, and White Rivers where active-channel width was measured and active-channel width was not constricted by bedrock 
In a widening river, the volume of sediment recruited from the flood plain is the product of the increase in active-channel width, the terrace elevation, and the length of the reach. If the channel elevation did not change over the period of interest, this calculation would estimate the sediment recruited into the active channel. In an incising system, additional sediment would be recruited from the flood plain, as well as the active channel as it erodes deeper into its bed, and the previous calculation would underestimate the total recruited sediment volume. For this analysis, it is assumed that few river reaches are appreciably incising - most incising rivers tend to narrow. If the channel aggraded over the period of interest, new sediment would deposit on the channel bed and the previous calculation would overestimate the contribution of sediment to the river. Because it is likely that most river reaches close to Mount Rainier are in a state of relative stasis or slight aggradation, the following calculations likely overestimate the sediment load recruited to the active channel through channel widening.

An estimate of the contribution of sediment due to active-channel widening was computed by multiplying terrace elevations by measured increases in active-channel width over the length of a reach. Annualized rates of change in active-channel width between 1965 and 1994 and between 1994 and 2009 bracket generalized lateral expansion of the active channel and represent a range of widening measured during the late 20th century. Bedrock-controlled reaches were not considered in the analysis. The annualized rates of positive change in active-channel width were multiplied by positive terrace thickness to estimate volumetric sediment contribution from the flood plain due to an expansion of the active channel (table 6). Additionally, the contribution to the river sediment load from the measured range of channel widening was determined by multiplying mobilized sediment volumes by the anticipated range of bulk density, 1.5-1.8 tonnes $/ \mathrm{m}^{3}$ (Wu and Wang, 2006). Finally, to compare results between rivers, volume estimates for each river were normalized by the length of river analyzed.

The rivers with the largest contributions of sediment from the flood plain to the active channel per unit length of channel are the Nisqually and Puyallup Rivers, likely due to the greater terrace thickness of the Nisqually and Puyallup Rivers relative to the White and Carbon Rivers. These estimates likely are overestimates of the sediment contribution from the flood plain because they only include recruitment from the flood plain (loss of flood-plain storage), not added storage of sediment in the flood plain, and the calculations ignore sediment storage within the active channel, which, for an aggrading system, could be significant. Nonetheless, the estimates establish an upper bound of the flood-plain contributions to the total sediment load.

\section{The Link between Superglacial Debris and Downstream Aggradation}

Observations of aggradation on rivers downstream of Mount Rainier (Beason, 2007; Czuba and others, 2010), coupled with documented 20th century retreat of glaciers on Mount Rainier (Harrison, 1956; Nylen, 2004; Sisson and others, 2011), have led researchers to consider the hypothesis that the two observations are linked. Nylen (2004) analyzed historical data sets to determine geospatial trends of glaciers on Mount Rainier including glacier retreat from 1913 to 1994, total area of each glacier as measured in 1971, and the percentage of total areal coverage of superglacial debris mantling each glacier in 1971. To determine if some physical characteristic of Mount Rainier glaciers explains differences in active-channel width of the rivers just downstream of the respective glacier, linear regressions were calculated between active-channel width and the three glacier parameters reported by Nylen (2004). In addition, a linear regression of active-channel width versus total drainage area of the catchment was analyzed to assess if catchment size, and thus, contributing hydrology, would explain the observed response in active-channel width.

Active-channel widths calculated with 2009 imagery (fig. 11) were averaged for each draining tributary from the glacier terminus to the first prominent tributary that enters from a different glacier 
(fig. 15). The regression showed little correlation between active-channel width and total drainage area $\left(\mathrm{R}^{2}=0.15\right)$. Similarly, there was only a weak correlation between active-channel width and total glacier area $\left(\mathrm{R}^{2}=0.33\right)$. The strongest correlation was between active-channel width and the total area of debris mantling the glacier as measured in $1971\left(\mathrm{R}^{2}=0.78\right)$. This correlation indicated that active-channel width, that is, recent geomorphic disturbance, was influenced by the presence of superglacial sediment mantling the glacier. For example, the mantling of 43 percent of the Carbon Glacier by sediment (Nylen, 2004) seemed to promote an average active-channel width of more than $200 \mathrm{~m}$ in the downstream reach. Conversely, the Puyallup River, which had an average active-channel width of about $50 \mathrm{~m}$ is fed by the Puyallup Glacier which was mantled with debris over 7 percent of its total area. Surprisingly, there was no correlation $\left(\mathrm{R}^{2}=0.0009\right)$ between active-channel width and the amount of glacier retreat during the 20th century. These data suggest that geomorphic disturbance of rivers draining Mount Rainier, as measured in 2009, was influenced by debris mantling on the glacier and little influenced by the magnitude of 20th-century glacier retreat.

\section{The Link between the 1963 Debris Avalanche and Upper White River Aggradation}

Aggradation in the White River just inside the national park boundary has been the cause of flooding to State Route 410 and a source of concern for officials at the Washington State Department of Transportation, the National Park Service, and Pierce County (Abbe and others, 2005). Analysis from this study shows that the reach of the White River from 8 to $18 \mathrm{~km}$ downstream of Emmons Glacier was in a state of acute aggradation in 2009 with an active-channel elevation that was flush with the forested terrace (fig. 14D). Both upstream and downstream of this aggraded reach, the forested terrace was about $2 \mathrm{~m}$ above the active channel. Assuming this $10-\mathrm{km}$ reach of localized aggradation is a pulse of sediment moving down the river corridor and that this pulse is 2-m deep and as wide as the activechannel width in this reach (about $125 \mathrm{~m}$, fig. 11), the total volume of sediment in this pulse is about 2.5 million $\mathrm{m}^{3}$.

Although one debris flow was documented from the Inter Glacier during November 2006 (Copeland, 2009), no debris flows have been documented from Emmons Glacier. Floods have affected the upper White River (Abbe and others, 2005). The 1963 sequence of rockfalls and debris avalanches deposited 11 million $\mathrm{m}^{3}$ of material over Emmons Glacier that extended well beyond the glacier terminus (Crandell and Fahnestock, 1965). More importantly, photographic evidence (fig. 3) showed that some portion of the debris was reworked and moved downstream into the fluvial network in the years following the rockfalls. Crandell (1971) and Czuba and others (2012) showed that about 25 percent of the large 1947 Kautz Creek debris flow transported downstream to Alder Lake. Assuming a similar ratio of sediment mobilization from the 1963 debris-avalanche deposit, it appears that the pulse of sediment causing the aggradation in the White River along State Route 410 may be predominantly sourced from the 1963 rockfall.

\section{Sediment Supply from Cascade Uplands outside Mount Rainier National Park}

Though aerial imagery suggested that the predominant source of sediment to rivers in the study area was Mount Rainier, mountainous catchments outside the national park, many of which are actively logged, also contribute to sediment load. To assess the potential for contribution from these other mountainous catchments, coarse-resolution, watershed-scale sediment-production potential was estimated. This sediment-production potential does not represent a sediment budget; rather, it assesses the potential for a subcatchment to generate sediment based on its topography, drainage network, landslide activity, and road density. Sediment contributions to the lower Puyallup River system from 
urban and lowland catchments were not considered. These lowland catchments tend not to produce large, naturally occurring sediment loads (Nelson, 1971, 1974).

In comprehensive sediment budgets, all processes that may produce sediment are considered, including wind erosion, rilling, tunnel erosion, animal burrowing, tree throw, dry ravel, land-use soil erosion, soil creep, landslides, and production from roads (Reid and Dunne, 1996). Full sediment budgets also account for transient storage and routing within the catchment. For this study, the potential for sediment delivery to the subcatchment outlets from roads, landslides, and soil creep in logged areas was assessed. These processes have been shown to be the dominant processes for sediment production from catchments (Dietrich and Dunne, 1978; Roberts and Church, 1986). These sediment-production estimates were then calibrated to known sediment-production rates from five subcatchments. Only contributing area from outside Mount Rainier National Park was considered. All sediment production inside the park boundary was assumed to originate from the volcano, and no effort was made to independently differentiate the magnitude of sediment production for forested lands inside the park from sediment sourced from the volcano.

\section{Methodology for Assessing Sediment-Production Potential}

Following the general recommendation of Dietrich and others (1982) and Reid and Dunne (1996), the sediment-production potential for subcatchments contributing to the Puyallup River basin and the upper Nisqually River basin was calculated. A total of 27 subcatchments that contribute to the White River upstream of Auburn, the Carbon River, the Puyallup River upstream of its confluence with the Carbon River, and the Nisqually River upstream of Alder Lake were delineated using USGS StreamStats (accessed September 4, 2012, at http://streamstats.usgs.gov/Washington.html) (fig. 16). Named tributary subcatchments were included as well as contributing areas from catchments along the corridor of each main-stem river. Large catchments along each main stem were delineated into smaller subcatchments. Three additional subcatchments outside the study area-Issaquah Creek, the Mashel River, and the upper Deschutes River - also were delineated to enable calibration of the methodology with published sediment-load data sets. Key basin hydrologic parameters for each subcatchment were recorded from StreamStats, including drainage area, elevation, relief, precipitation, and percentage of catchment with slopes greater than 30 percent.

Roads

Sediment production from roads was estimated using data from Reid and Dunne's (1984) study of sediment production from roads in logged areas of the Clearwater River basin in the Olympic Mountains. Geographic information system (GIS) data of road networks within the subcatchments were downloaded from the Washington State Department of Natural Resources (DNR). The data indicated the location of roads, road length, general usage characteristics, and provided information on road surfacing (unpaved, paved, gravel, crushed rock, pitrun, natural material, and unknown). For each length of road in a given subcatchment, sediment production was estimated by applying yield data of Reid and Dunne (1984) to the road-usage category. Roads labeled as unpaved, crushed rock, gravel, pitrun, and native material were assumed to generate sediment yields of 3.8 (tonnes $/ \mathrm{km}$ ) $/ \mathrm{yr}$. Paved roads were assumed to generated sediment yields of 2.0 (tonnes $/ \mathrm{km}) / \mathrm{yr}$. Abandoned roads were assumed to generate a sediment yield of 0.51 (tonnes $/ \mathrm{km}$ ) $/ \mathrm{yr}$. Roads not classified by usage were assumed to be abandoned. This combination of sediment yield by road type produced results that most reasonably approximated sediment production in subcatchments where sediment loads were known from published studies. Uncertainty in the estimate of sediment production from roads was estimated to be 50 percent. 


\section{Landslides}

Updated GIS data of mapped landslides within the study area, supplied by DNR (Isabelle Sarikhan, Washington Department of Natural Resources, written commun., 2012), were used to assess the sediment production by landslides from each subcatchment. DNR conducts mapping of forested lands to assist foresters and land managers in identifying unstable slopes under the Landslide Hazard Zonation Project (accessed September 4, 2012, at http://www.dnr.wa.gov/BusinessPermits/Topics/LandslideHazardZonation/Pages/Home.aspx). For the mapped watersheds, the total extent of active-landslide area was available as well as the types of landslides (deep seated and shallow as well as active and inactive). No effort was made to differentiate sediment-production rates from individual landslides by category. Nelson and Booth (2002) completed a sediment budget of the Issaquah Creek catchment (a western Cascade Range catchment with topographic and hydrologic characteristics similar to the subcatchments just outside Mount Rainier National Park) and determined that 3,264 tonnes/yr was sourced from landslides. According to DNR landslide mapping, Issaquah Creek contained $18 \mathrm{~km}^{2}$ of landslides. Therefore, the sediment yield from landslide-contributing areas in the Issaquah Creek subcatchment was 182 (tonnes $/ \mathrm{km}^{2}$ ) $/ \mathrm{yr}$. This landslide sediment-production yield was multiplied by the landslide area in other mapped subcatchments to determine sediment production by landslides. For subcatchments not mapped for landslides by DNR, the total active-landslide area was first estimated by building a linear regression of data from mapped subcatchments relating total active-landslide area to the percent of the basin with slopes greater than 30 percent. This regression relation was used to estimate total landslide area in unmapped subcatchments using StreamStats data of basin area with slopes greater than 30 percent. This estimated landslide area was multiplied by the Nelson and Booth (2002) landslide yield to predict sediment production by landslides in unmapped subcatchments. Uncertainty in the estimate of sediment production from landslides was estimated to be 50 percent where landslides were mapped by DNR, and 75 percent where no mapping was available. Because of resource limitations in this study, a more detailed and comprehensive analysis of sediment production from landslide potential was not possible, but future research attempting a more fully developed sediment budget would benefit from more rigorous estimates of landslide potential (Montgomery and Dietrich, 1994; Montgomery and others, 1998).

\section{Soil Creep}

Roberts and Church (1986) assimilated data from literature collected in the Pacific Northwest to estimate that the rate of sediment delivery from logged slopes by soil-creep processes was $6-40 \mathrm{~m}^{3} / \mathrm{yr}$ per kilometer of channel length along higher-order streams in the catchment. Assuming a bulk density of 1.65 tonnes $/ \mathrm{m}^{3}$ (Wu and Wang, 2006), sediment load from soil creep was estimated to be 10-66 (tonnes $/ \mathrm{km}$ ) $/ \mathrm{yr}$ from logged slopes. To apply these soil-creep estimates to subcatchments of this study, the assumption was made that soil creep predominantly occurs on slopes greater than 30 percent. Using the National Hydrography Dataset, the total length of natural streams within each subcatchment categorized as perennial was calculated in ArcGIS and multiplied by the soil-creep estimates of Roberts and Church (1986), factoring in the total catchment area with slopes greater than 30 percent. Uncertainty in the estimate of sediment production from soil creep was 74 percent, a value directly taken from the published range of Roberts and Church (1986).

\section{Calibration}

Calculations of sediment-production potential were calibrated using known sediment-load data from the five calibration subcatchments. Two of the calibration subcatchments, Mineral Creek and the 
Little Nisqually River, were within the study area. Two other calibration catchments, Mashel River and the Deschutes River near La Grande, Washington, were just west of the study area. The fifth calibration subcatchment, Issaquah Creek, drains the Cascade Range into Lake Sammamish about $50 \mathrm{~km}$ north of the White River. Total sediment load from Mineral Creek (15,000 tonnes/yr), Mashel River (16,000 tonnes/yr), and Deschutes River near La Grande (21,000 tonnes/yr) were determined by multiplying Nelson's (1974) suspended-sediment load estimates, based on measurements taken in 1971-1972, by 107 percent to account for bedload, estimated by Nelson to be between 4 and 10 percent of the total load. The total sediment-load estimates of the Little Nisqually River were based on measurements of accumulated delta sediment in Alder Lake (Czuba and others, 2012). Estimates of total sediment load for Issaquah Creek were taken from Nelson and Booth (2002). It was found that the sum of the raw estimates of sediment product from roads, landslides, and soil creep was less than the known sediment production from the calibration subcatchments. Multiplying the predicted raw sediment production by a scaling factor of 2.5 produced a minimum residual error (Helsel and Hirsch, 1992) between predicted sediment production and the known sediment production. This scaling factor was applied to the raw estimates of sediment production from each subcatchment to generate final estimates. The uncertainty in the estimates of total sediment production from each subcatchment was determined by summing the uncertainties of each individual sediment-producing component.

\section{Sediment-Production Potential Results}

The correlation between the predictions of sediment production from subcatchments with the measured sediment loads was not strong, but it was reasonable given the uncertainty in the process (fig. 17). The prediction of sediment production from Issaquah Creek was larger than published sedimentload data, and the prediction of sediment production from the Deschutes River near La Grande was less than the published value. Predictions of the other three calibration subcatchments were better. Estimating sediment load from a catchment using indirect approaches typically results in large uncertainty (Reid and Dunne, 1996). The methodology mostly fails to capture the contribution of large, infrequent storm events that have major hydrogeomorphic effects on the catchment (Reneau and Dietrich, 1991; Benda and Dunne, 1997). These large, infrequent storms can cause widespread landslide activity and release significant volumes of sediment into the river network (Wemple and others, 2001; Turner and others, 2010). Nevertheless, the approach is useful to assess relative contributions of sediment between subcatchments during typical hydrologic water years. The methodology is also useful to assess how much of the total sediment loads measured on main-stem reaches of the Puyallup and Nisqually River is sourced from the Cascade uplands as opposed to Mount Rainier National Park under typical conditions.

Within the study area, subcatchments draining into the White River contributed the largest quantity of sediment load (table 7). A total of 130,000 $\pm 89,000$ tonnes/yr was predicted to be delivered to the White River, mostly from the contributing subcatchment along the middle section of the White River and from the Greenwater and Clearwater Rivers (fig. 18). These subcatchments had considerable sediment contributions from soil-creep processes, related to the relatively large contributing area of slopes greater than 30 percent. Sediment production from landslides also was significant, and DNR mapped large areas of landslide activity within these subcatchments. Sediment yield from White River subcatchments ranged from 77 to 240 (tonnes $/ \mathrm{km}^{2}$ ) $/ \mathrm{yr}$ and averaged 140 (tonnes $/ \mathrm{km}^{2}$ ) $/ \mathrm{yr}$ for the White River basin, consistent with published yield measurements of western Cascade uplands (Nelson, 1971; Nelson, 1974; Nelson and Booth, 2002). Sediment production values from the Nisqually, Puyallup, and Carbon River basins were all less than the sediment production from the White River basin. The sediment production was smallest from the Carbon River basin (42,000 $\pm 28,000$ tonnes/yr) and the 
Puyallup River basin (42,000 $\pm 29,000$ tonnes/yr), and the sediment production from the Nisqually River Basin was 50,000 $\pm 33,000$ tonnes/yr. Yields were 84, 120, and 86 (tonnes $/ \mathrm{km}^{2}$ ) $/ \mathrm{yr}$ for the Nisqually, Puyallup, and Carbon River basins, respectively. Summing the sediment production from subcatchments in the Puyallup, Carbon, and White Rivers basins, which collect into the lower Puyallup River, resulted in a total sediment production of $210,000 \pm 150,000$ tonnes/yr and a yield of 120 (tonnes $\left./ \mathrm{km}^{2}\right) / \mathrm{yr}$.

\section{Estimates of Sediment Loads using Historical and New Data}

Long-term sediment-load estimates of the upper Nisqually River were calculated using the reservoir-sediment data of Czuba and others (2012). Variation of sediment concentration and load by season is assessed using high-resolution data collected by Nelson (1978) along the upper White River. The suspended-sediment load in the lower Puyallup River from 1978-1994 was calculated using available suspended-sediment concentration data collected by the USGS and available through the National Water Information System (NWIS). Recent (April 2010-March 2012) sediment-load estimates along the lower White River, using turbidity as a suspended-sediment-concentration surrogate, also were calculated. Finally, a rough bedload-transport relation was constructed from available bedload measurements and used to infer relative magnitude of bedload in the White, Carbon, and Puyallup Rivers where they exit the mountain front and first enter the Puget Lowland.

\section{Load Estimates of the Upper Nisqually River}

Czuba and others (2012) calculated the rate of accumulated sediment in Alder Lake from the Nisqually River from 1945 to 2011 (66 years) to be 660,000 $\pm 60,000 \mathrm{~m}^{3} / \mathrm{yr}$. Czuba and others (2012) also reported the rate of accumulated sediment in Alder Lake from the Little Nisqually River over a period of 66 years to be $4,700 \pm 1,600 \mathrm{~m}^{3} / \mathrm{yr}$. To estimate the total sediment load of the Nisqually and Little Nisqually Rivers into Alder Lake, a correction for trap efficiency of the reservoir is needed.

No direct assessment of the trap efficiency of Alder Lake is available. Trap efficiency is a function of reservoir size relative to the volumetric inflow, dam operations, hydrology, and the characteristic particle size of the delivered sediment load (Brune, 1953). Trap efficiency of bedload for large reservoirs is nearly 100 percent if the delta front is far from the dam, and trap efficiency decreases with decreasing sediment size. For suspended-sediment load, aerial imagery and turbidity data downstream of Alder Lake suggest some portion of the fine-grained load passes the dam. Nelson (1974) reported the suspended-sediment load in the Nisqually River upstream and downstream of the dam to be 300,000 and 42,000 tonnes/yr, respectively. Assuming these differences in load represent a proxy for trap efficiency, the Alder Lake trap efficiency, as indirectly measured by Nelson in 1971-1972, was 0.87. Using the empirical estimates of Brune (1953), trap efficiency was estimated using the nondimensional ratio of reservoir capacity to annual inflow. The reservoir capacity of Alder Lake as constructed was 287 million $\mathrm{m}^{3}$; the reservoir capacity in 2011 was about 245 million $\mathrm{m}^{3}$ (Czuba and others, 2012). The combined mean annual flow of the Nisqually River near National gage (12082500) and Mineral Creek near Mineral gage (12083000) is $32.3 \mathrm{~m}^{3} / \mathrm{s}\left(1,140 \mathrm{ft}^{3} / \mathrm{s}\right)$. Using Brune's (1953) empirical model, the trap efficiency of Alder Lake is about 0.94 . For the purposes of this analysis, the trap efficiency of Alder Lake for Nisqually River load was estimated to be $0.90 \pm 0.05$. Owing to small annual inflow, the Alder Lake trap efficiency for the Little Nisqually River load was estimated to be 1.0.

Accounting for trap efficiency, the total sediment load of the Nisqually River into Alder Lake between 1945 and 2011 was estimated to be 740,000 $100,000 \mathrm{~m}^{3} / \mathrm{yr}$. Similarly, the total sediment load of the Little Nisqually River into Alder Lake was estimated to be $4,700 \pm 1,600 \mathrm{~m}^{3} / \mathrm{yr}$. The bulk density 
of accumulated sediment in Alder Lake was estimated to be between 1.5 and 1.8 tonnes $/ \mathrm{m}^{3}$ (Wu and Wang, 2006). Therefore, the total sediment load in the Nisqually River between 1945 and 2011 was 1,200,000 $\pm 180,000$ tonnes/yr, and the total sediment load in the Little Nisqually River between 1945 and 2011 was 7,800 $\pm 2,600$ tonnes/yr. The total annual sediment yields of the Nisqually and Little Nisqually Rivers were 2,000 \pm 300 and $120 \pm 39$ (tonnes $/ \mathrm{km}^{2}$ )/yr, respectively, an order of magnitude difference in yield. The total annual sediment load passing Alder Dam and delivered downstream

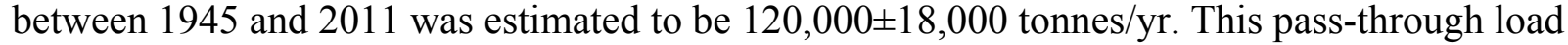
predominantly consists of fine-grained sediment that transports through the reservoir and is likely delivered to the Nisqually River delta in Puget Sound. Because the middle to late 20th century was a less-active hydrogeomorphic time period for Mount Rainier, the average load of the Nisqually River into Alder Lake from 1956 to 1985 also was calculated using available bathymetric data from Czuba and others (2012) and the previously mentioned methodology. The total load of the upper Nisqually River from 1956 to 1985 was 860,000 $\pm 370,000$ tonnes/yr, or about 70 percent of the long-term annual load.

\section{Seasonality in Suspended-Sediment Concentration in Mount Rainier Rivers}

Suspended-sediment concentration was sampled between 1974 and 1976 by Nelson (1978; U.S. Geological Survey, 2012b) at the White River below Clearwater near Buckley gage (12097850). These data were grouped into four 3-month seasons, or hydrologic quarters, and show the strong seasonality of suspended-sediment concentration of the glacier-draining White River throughout the year (fig. 19). During the summer quarter (July-September), warm temperatures result in glacial melt, increasing finesediment load and producing high suspended-sediment concentrations. The early flood-season quarter (October-December) also has high suspended-sediment concentrations. By the late flood-season quarter (January-March), much of the fine sediment has been flushed from the river corridor, which results in lower overall suspended-sediment concentrations. The snowmelt freshet quarter (April-June) has the lowest concentrations of suspended sediment. The observed seasonality in suspended-sediment concentration at the White River below Clearwater River near Buckley gage (12097850) is consistent with observations of seasonality in suspended-sediment concentration at other glacial-fed catchments in western Washington, specifically the Skagit River (Czuba and others, 2011).

\section{Suspended-Sediment Load of the Puyallup River from 1978 to 1994}

Horowitz (2003) presented a methodology to calculate annual sediment load at gages where suspended sediment is only periodically measured. Using the Horowitz approach, all available suspended-sediment and concurrently measured discharge data collected from the lower Puyallup River from WYs 1978-1994 were compiled and segregated by hydrologic quarters (summer, early flood season, late flood season, and snowmelt freshet). These data were then log transformed. For each data group, both a linear and second-order polynomial regression was applied. A "smearing correction," to compensate for bias in converting the data set from log space to arithmetic space (Duan, 1983), also was applied. For each data group, these steps produced four candidate regression models for the final load estimates: (1) linear uncorrected, (2) linear "smearing" corrected, (3) polynomial uncorrected, and (4) polynomial "smearing" corrected (Horowitz, 2003). Of the four candidate models, the one that produced a total load estimate closest to the measured load from the known data set was used to predict suspended-sediment concentrations using the full hydrologic record from WYs 1978-1994. For the Puyallup River data set, a linear uncorrected model best represented the two flood-season quarters and a polynomial "smearing" corrected model best represented the summer and snowmelt freshet quarters. 
Suspended-sediment concentration was measured 84 times between WY 1978 and 1994 at the Puyallup River at Puyallup gage (U.S. Geological Survey, 2012b) (fig. 20). Data were measured periodically throughout the year, with 5-6 samples typically collected per year; 20 samples were collected in the summer quarter, 16 samples were collected in the early flood-season quarter, 23 samples were collected in the late flood-season quarter, and 25 samples were collected in the snowmelt freshet quarter. The data showed seasonality in suspended-sediment concentration, although the signal was not as strong as the seasonality demonstrated for the White River below Clearwater River near Buckley gage (fig. 19).

Yearly suspended-sediment load calculations for the lower Puyallup River for the period from 1978 to 1994 were as large as 1.7 million tonnes in WY 1991 and as small as 220,000 tonnes in WY 1994 (fig. 21). This near-order-of-magnitude variation in annual loads is typical for rivers and is strongly related to the hydrological conditions from year to year. The mean suspended-sediment load during this 17-year time period was estimated to be $860,000 \pm 300,000$ tonnes/yr, where the uncertainty represents interannual variability. The period of time between 1978 and 1994 was a less-active hydrogeomorphic period. Loads were likely larger during more-active hydrogeomorphic time periods, such as from 1996 to 2009.

\section{Sediment-Load Estimates of the White River from Recent Measurements}

Suspended-sediment concentration and bedload measurements were collected along the lower White River from April 2010 to March 2012. These data were used to estimate the total sediment load for the lower White River.

\section{Collection of Sediment Data and Calculation of Sediment Loads}

Fluvial sediment data were collected over a range of flows at the White River at R Street near Auburn gage (12100490) from April 2010 to March 2012. Suspended-sediment concentration data were collected using the equal discharge increment (EDI) method and bedload data were collected using the multiple equal width increment (MEWI) method (Edwards and Glysson, 1999). Suspended-sediment concentration data were collected using a variety of depth-integrated samplers approved by the Federal Interagency Sedimentation Project (FISP) and routinely used by USGS personnel (Davis, 2005). Bedload data were collected using a modified Helley-Smith sampler (also referred to as an Elwha sampler) with a 20 - by 10 -cm opening and a 1.40 expansion ratio as described by Childers and others (2000). All sediment samples were analyzed at the USGS sediment laboratory at the Cascades Volcano Observatory in Vancouver, Washington, to determine either the concentration and percentage of fines (less than $0.0625 \mathrm{~mm}$ ) of suspended-sediment samples or the particle-size distribution for bedload samples.

Turbidity was continuously monitored during the period of sediment sampling, with the exception of intermittent periods when instrument failure or excessive fouling occurred. Turbidity was measured using a YSITM 6136 optical turbidity sensor enclosed within a protective pipe that was freely suspended from a bridge rail. This mounting arrangement allowed turbidity measurements in an actively flowing part of the river channel and decreased the likelihood of debris build-up around the sensor face or on the mounting hardware, which could foul sensor readings. Turbidity data were recorded at 15minute intervals and were included in the transmission of real-time data of the streamflow-gaging station. USGS protocols for the operation and maintenance of continuous water-quality instruments were followed as outlined by Wagner and others (2006), and the time-series data were processed and reviewed according to established USGS policy for continuous water-quality data. Standard USGS 
guidelines were followed for using turbidity as a surrogate measurement for suspended-sediment concentration (Rasmussen and others, 2009), enabling the calculation of suspended-sediment loads.

Regression equations were developed for estimating a time series of the concentration of suspended sediment and the fraction of fine-grained (less than $0.625 \mathrm{~mm}$ ) suspended sediment based on EDI concentrations and either turbidity or streamflow (during periods when turbidity data were not available) recorded at the time of sample collection. The chosen form of the regression equations was selected based on the coefficient of determination $\left(\mathrm{R}^{2}\right)$ from several regression equations that were developed using various logarithmic transformations. Upper and lower confidence intervals for regression models were determined at the 95-percent level. A time series of suspended-sediment concentration was computed by applying the appropriate regression equation using turbidity or streamflow time-series data. Suspended-sediment load was computed by multiplying suspendedsediment concentration with streamflow. A regression equation was developed for estimating bedload based on the mass of MEWI samples and the recorded streamflow. Instantaneous bedload discharge (tonnes/d) was computed from a regression equation using instantaneous streamflow.

Suspended-Sediment Load and Bedload of the White River

At the White River at R Street near Auburn gage (12100490), six measurements of suspendedsediment concentration (appendix A, table A2) and five measurements of bedload (appendix A, table A3) were made between June 2, 2010, and January 20, 2011. The regression equations used to estimate suspended-sediment concentration from turbidity and bedload from streamflow are shown in figures 22 and 23, respectively. Suspended-sediment concentration and suspended-sediment loads were computed between April 1, 2010, and March 31, 2012 (fig. 24). The sediment measurements made during this time period represent conditions through a range of measured streamflow, from 22 to $202 \mathrm{~m}^{3} / \mathrm{s}(773-$ $7,150 \mathrm{ft}^{3} / \mathrm{s}$ ), and the average discharge at the Puyallup River at Puyallup gage (12101500) for this time period was 115 percent of the mean annual flow. The concentration of suspended sediment generally peaked around the same time as streamflow; however, the magnitude of the concentration of suspended sediment was not consistent with streamflow (fig. 24).

For WY 2011, at White River at R Street, the suspended-sediment load was 527,000 tonnes, of which 222,000 tonnes or 42 percent was fines (less than $0.0625 \mathrm{~mm}$ ). The bedload was 65,000 tonnes, of which 45,000 tonnes or 70 percent was gravel and cobbles (greater than $2 \mathrm{~mm}$ ). A relatively small number of storm events during the winter flood season transported the majority of load during the water year (fig. 25). The total sediment load was 590,000 tonnes, composed of 37 percent fines (less than $0.0625 \mathrm{~mm}), 55$ percent sand $(0.0625-2 \mathrm{~mm})$, and 8 percent gravel and cobbles (greater than $2 \mathrm{~mm}$ ). Approximately 11 percent of the total sediment load was transported as bedload. For the longer 24month period of monitoring from April 2010 to March 2012, the average suspended-sediment load was 370,000 tonnes/yr, the average bedload was 46,000 tonnes/yr, and the total sediment load was 420,000 tonnes/yr.

Calculations of loads for the White River from each seasonal quarter from April 2010 through March 2012 show the variation by season and variation between years (fig. 26). For WY 2011, the late flood-season quarter (January-March) had the largest loads of about 250,000 tonnes and the summer and early flood-season quarters (July-September and October-December, respectively) had the smallest loads of the year, about 35,000 tonnes. During the two-year period of data, the late flood-season loads for a given water year were greater than the early-season loads, but during many years of data collection, the average loads for these two flood-season quarters would likely be similar because the largest floods typically affect the region between November and January. For the measured data, loads were comparable between the early flood-season quarter (October-December) and the snowmelt freshet 
quarter (April-June). The loads during the summer season (July-September) were the smallest during the year because of less discharge, even though the suspended-sediment concentration was highest in the summer from the presence of glacial flour (fig. 19).

\section{Estimated Bedload-Transport relation for the White, Puyallup, and Carbon Rivers}

Within the aggrading reaches of the Puyallup and White Rivers, where they exit the mountain front and enter the Puget Lowland, knowledge of bedload is important to flood-risk managers making river-management decisions to maintain flood-conveyance capacity. Czuba and others (2010) found that between 1984 and 2009, 418,000 $\mathrm{m}^{3}$ of new sediment accumulated in the White River between R Street and the Lake Tapps return, a 12.2-km reach mostly confined by levees and revetments where the slope is small relative to the upstream reach. The annualized mass accumulation rate in this reach was 28,000 tonnes/yr, assuming a bulk density of 1.65 tonnes $/ \mathrm{m}^{3}$ (Wu and Wang, 2006). Czuba and others (2010) also reported that $1,020,000 \mathrm{~m}^{3}$ of sediment accumulated between 1984 and 2009 along the Puyallup River from the gage near Orting (12093500) to the confluence with the Carbon River, a 12.9-km reach where the slope does not change substantially relative to the upstream reach. Most measured aggradation occurred within two setback-levee reaches (completed in 1998 and 2006), and Czuba and others (2010) attributed the enhanced aggradation to river response to the setback levees. The annualized mass accumulation rate in this reach was 67,000 tonnes/yr. No appreciable aggradation was found along the Carbon River between 1984 and 2009, though comparative 1984 cross sections did not extend far up the Carbon River corridor (Czuba and others, 2010).

Relatively few bedload measurements have been collected in Puget Lowland rivers, but Sikonia (1990) did collect bedload data in the Puyallup, Carbon, and White Rivers in 1986. Sikonia's bedload measurements from the lower Carbon, Puyallup, and White Rivers near the mountain front in the Puget Lowland were collected at the Carbon River near Orting gage (12094300, referred to as the Carbon River at Crocker by Sikonia, 1990), the Puyallup River near Orting gage (12093500), and the White River at R Street near Auburn gage (12100490) (Sikonia, 1990; U.S. Geological Survey, 2012b). Combining these data collected by Sikonia with bedload data measured on the White River at R Street by the USGS in 2010 and 2011 (appendix A, table A2) allowed the generation of a generalized bedloaddischarge relation applicable to the Puyallup, Carbon, and White Rivers where these rivers exit the mountain front. Despite the fact that these data were taken from separate rivers, bedload-discharge data fit into a close grouping, which was approximated with a single power-law function (fig. 27). Lack of bedload data precluded the development of a similar bedload power-law function for the upper Nisqually River. The power-law function developed for the lowland rivers was not applicable to the upper Nisqually River due to differences in hydraulic geometry, proximity to the volcano, and geomorphic setting. Bedload data were comparable between lowland rivers because each river at the mountain front has similar slopes (fig. 4A), channel widths (Czuba and others, 2010), and characteristic particle sizes (fig. 6) at the locations of bedload data collection. This combined bedload-discharge relation cannot be used as a precise predictor of bedload on each river; however, the simple model can be used to assess order-of-magnitude bedload potential between each river and serve as a useful analytical tool to predict how changes in future hydrology might impact overall bedload transport.

Using the bedload-transport relation (fig. 27), daily estimates of bedload from WY 1984 to 2011 were computed at the White River at R Street (drainage area 1,230 $\mathrm{km}^{2}$ ), the Puyallup River near Orting (drainage area $450 \mathrm{~km}^{2}$; measured at the Calistoga Street bridge), and the Carbon River just upstream of South Prairie Creek (drainage area $250 \mathrm{~km}^{2}$; measured at the State Route 162 bridge) using daily streamflow data from the closest available long-term gaging station data scaled for contributing

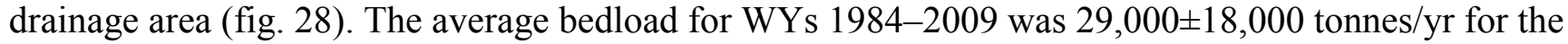




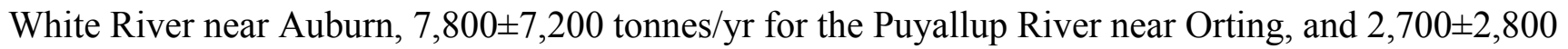
tonnes/yr for the Carbon River near Orting; the stated accuracy is the standard deviation of bedload variation by year. Because the same bedload-transport relation is assumed to apply to all three rivers, the cumulative bedload reported here reflects the differences in the underlying peak-flow hydrology. Despite regulation at Mud Mountain Dam, the White River showed a larger potential to transport bedload than the Puyallup and Carbon Rivers. High flows released from Mud Mountain Dam were sufficient, when summed over a given water year, to move significant volumes of bedload. In contrast, the overall hydrologic flows in the Puyallup River were notably smaller than flows in the White River, reflecting the smaller catchment area. Bedload estimates for the Carbon River were smaller than the estimates for the Puyallup River, further reflecting the influence of a smaller contributing drainage area. The bedload model indicated that from 1984 to 2011, the White River transported about four times more bedload than the Puyallup River and about 11 times more bedload than the Carbon River. Particular water years stood out as significant in moving bedload, including 1996, 2007, and 2009. For example, the hydrologic conditions in WY 1996 were such that the model predicted that 37,000 tonnes of bedload moved down the Puyallup River, nearly five times the long-term average value.

Comparing bedload estimates from the bedload equation to suspended-sediment load from the lower Puyallup River, long-term bed-material accumulation in the lower White River, recent measurements of annual bedload in the lower White River, and long-term bed-material accumulation in the Puyallup River allows an assessment of how the simple model predicts bedload in the system. Typically, about 4-10 percent of total load is bedload (Nelson, 1971; Nelson, 1974). The suspended-

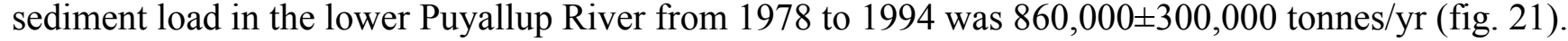
The sum of estimated annual bedload from 1978 to 1994 in the three rivers draining into the lower Puyallup River was 33,000 tonnes/yr, which is 3.7 percent of the total load for the same time period. This comparison suggests the bedload equation may underpredict actual bedload, but overall, the predictions are reasonable. Comparing predicted bedload in the White River with accumulation in the reach between R Street and Lake Tapps (Czuba and others, 2010) showed good agreement between the two, assuming that much of the White River bedload passing R Street deposits in the reach of decreased slope upstream of the Lake Tapps return and the finer sediment is carried downstream. The predicted bedload at the White River at R Street for WY 2011 was 49,000 tonnes (fig. 28), which was smaller than the reported bedload of 64,500 tonnes (fig. 25) but a reasonable estimate given the uncertainty in both values. Comparison of the bedload prediction with the measured sediment-accumulation rate of 67,000 tonnes/yr in the Puyallup River (Czuba and others, 2010) showed poor agreement. Though the bedload equation likely underpredicted actual bedload in the Puyallup River, the order-of-magnitude difference between predicted bedload in the Puyallup River and the long-term sediment accumulation suggests that perhaps pulses of sediment were mobilized from larger flood events (notably, the 1996 and 2006 floods) in the catchment that resulted in increased bedload transport. More likely, it is possible that setback-levee reaches trapped a larger proportion of the total load as bed material, including finegrained sediment not typically part of the bedload. Under this second scenario, the bedload relation could reasonably predict bedload for the Puyallup River, but the volume of sediment collected in the setback-levee reaches includes bedload and a sizeable portion of the suspended load. In considering the whole of available comparative data, it appears that, though imprecise, this simple bedload equation reasonably predicts bedload for the Puyallup, Carbon, and White Rivers where these rivers exit the mountain front.

Projections of future climate-change impacts in Washington State during the 21 st century predict increases in streamflow for October-March of 11.6 percent for 2010-2034 and of 18.1 percent for 2035-2059 (compared with the mean streamflow during 1917-2006; Elsner and others, 2010). 
Assuming the bedload relation (fig. 27) represents future bedload conditions and that the system remains in a state of sediment surplus, during the next 25 years, an increase in streamflow of 11.6 percent would result in an increase in bedload of 30 percent. During the following 25 -year period (2550 years in the future), an increase in streamflow of 18.1 percent would result in an increase in bedload of 48 percent. If the average bedload of the White River at R Street near Auburn from 1984 to 2009 was 28,000 tonnes/yr (Czuba and others, 2010), then average bedload will be approximately 36,000 tonnes/yr from 2010-2034 and 41,000 tonnes/yr from 2035-2059. Close monitoring of aggradation and bedload in aggrading reaches of lowland rivers in coming decades will aid resource managers in assessing changes in flood-conveyance capacity, particularly given that subtle increases in peak-flow hydrology has the potential to significantly increase bedload.

\section{Synthesis of Sediment Load of Mount Rainier Rivers}

Without the resources to directly measure long-term sediment loads or in the absence of reservoirs that trap a large portion of the load, a combination of analyses of existing data sets, published literature, and strategic sediment sampling allows an approximate estimation of long-term sediment loads. This section synthesizes disparate analyses and data sets previously discussed to generate best estimates for total sediment load in rivers in the study area.

\section{Best Estimate of Current Sediment Loads}

The best estimates of long-term sediment loads within the study area were for the Nisqually River system (table 8). Using sediment accumulation volumes (Czuba and others, 2012) and estimates of trap efficiency, the total sediment load of the upper Nisqually River into Alder Lake was found to be $1,200,000 \pm 180,000$ tonnes/yr during the time period 1945-2011. Trap efficiency in Alder Lake is $0.90 \pm 0.05$, and 120,000 $\pm 18,000$ tonnes/yr of load passes Alder Dam. Based on active-channel widths, the relative contribution of sediment loads from Tahoma Creek, Kautz Creek, and the main-stem Nisqually River, the three primary tributaries in the Nisqually River watershed draining Mount Rainier, were similar. During much of the 20th century and up to 2011, the Nisqually River was subjected to several large peak-flow events and significant debris-flow activity on Mount Rainier (Crandell, 1971; Walder and Driedger, 1994; Beason and Kennard, 2007; Lancaster and others, 2012). Total sediment load in the Nisqually River was large in the years following the 1947 Kautz Creek debris flow and from the 1990s to the present. However, loads decreased from 1956 to 1985 to $860,000 \pm 370,000$ tonnes/yr as overall peak flows were modest in magnitude and an apparent decrease in debris-flow activity. Although the spate of debris flows that impacted Tahoma Creek started in 1967, evidence suggests that much of this sediment remained in Tahoma Creek through 1985 (Walder and Driedger, 1994). Analysis of changes in active-channel width from 1965 to 1994 supports conclusions that the Nisqually River catchment was in a state of less-active hydrogeomorphic activity from the 1960s to the 1980s. Starting in 1990, hydrogeomorphic activity in the Nisqually River catchment increased. In the 1990s, several summer outburst debris flows supplied significant volumes of sediment to the Nisqually River basin inside Mount Rainier National Park. From 1996 to 2009, a series of large floods and debris flows from Mount Rainier increased overall sediment load in the main-stem Nisqually River, increased activechannel width along several river reaches outside the park boundary, and led to marked periods of both incision and aggradation at the Nisqually River near National gaging station (Czuba and others, 2010).

For the lower Puyallup River, the suspended-sediment load between 1978 and 1994 was estimated to be $860,000 \pm 300,000$ tonnes/yr (table 8 ) based on periodic suspended-sediment measurements collected by the USGS. This load estimate is likely smaller than the long-term load during much of the 20th century based on loads calculated for the Nisqually River. Though not 
determined, it is likely that large peak flows and sediment released from Mount Rainer starting in the 1990s increased the sediment load of the Puyallup River to about 1.0 million tonnes/yr, an estimate partially confirmed by Wise and others (2007) who found 1.25 million tonnes of sediment flowed down the lower Puyallup River in 2000. Dunne's (1986) estimate of total sediment load on the White River of 450,000 tonnes/yr was likely a reasonable estimate of annualized loads from the 1960s to 1980s, although the White River load since the 1990s was likely about 500,000 tonnes/yr, a value that agrees with estimates of sediment load from April 2010 to March 2012 made during this study (table 8). Based on active-channel width analysis, the West Fork White, White, Carbon, and Mowich Rivers supplied significant sediment to the river network between 1994 and 2009. In contrast, the main-stem and South Puyallup Rivers (fig. 1) supplied less sediment. Few sediment-load data for the Carbon River are available.

Bedload estimates for the Puyallup, Carbon, and White Rivers, where these rivers exit the mountain front and first enter the Puget Lowland, suggested that overall bedload-transport capacity along the White River, owing in part to the size of drainage area, is larger than along both the Puyallup and Carbon Rivers. In contrast, the Carbon River has a relatively small bedload-transport capacity due to a relatively small contributing drainage area.

No load estimates for the Cowlitz River drainage were made as part of this study, though gage analysis of the Cowlitz River at Packwood (Czuba and others, 2010), the relative absence of debris-flow activity from the upper Muddy Fork Cowlitz and Ohanapecosh Rivers draining Mount Rainier (Nick Legg, Oregon State University, written commun., 2011), and relatively modest changes in activechannel width from 1994 to 2009 suggest that the overall sediment load of the Cowlitz River is less than the overall sediment load of other rivers draining the volcano.

Insufficient data are available to determine definitively if post-1990 increases in sediment production and transport from Mount Rainier represent a statistically significant trend relative to sediment-production values typical from Mount Rainier during the 20th century. The more complete data sets collected since the 1940s - that is, sediment accumulation in Alder Lake, sediment-load data collected from the 1970s to the present, and hydrologic data from gaging stations around the mountain - indicate that sediment loads from 1990 to the present are likely greater than sediment loads in comparable river reaches from the 1960s to the 1980s. However, the data sets are too limited to determine if the increased post-1990 sediment loads are significantly larger than sediment loads from the 1940 s to $1960 \mathrm{~s}$. The hydrologic data of total runoff and peak flows indicate that flows of the 1940s1960s were similar to flows since 1990. Moreover, the sediment accumulation data from Alder Lake indicates sediment loads in the Nisqually River from 1945 to 1956 were similar to sediment loads measured from 1985 to 2011. Given these data, it appears that post-1990 sediment loads in rivers draining Mount Rainier are not unusual or significantly larger than loads typical during the entire 20th century.

\section{Regional Context}

Comparing the sediment-load estimates from this study to other rivers shows that rivers draining Mount Rainier generally carry larger sediment loads than similarly sized rivers in the Pacific Northwest not draining volcanos (fig. 29). The Nisqually River, with a long-term yield of 2,000 \pm 300 (tonnes $\left./ \mathrm{km}^{2}\right) / \mathrm{yr}$, carries a load that is in the upper range of variation from other rivers reflecting both significant response to hydrogeomorphic disturbance to the catchment and proximity to the source material. Nelson $(1971,1974)$ found that rivers draining the Cascade Range in western Washington away from volcanoes typically carry sediment yields ranging from 50 to 250 (tonnes $/ \mathrm{km}^{2}$ ) $/ \mathrm{yr}$. Milliman and Farnsworth (2011) reported a larger range of yield values from larger Pacific Northwest river 
systems directly draining to the Pacific Ocean. Sediment yields for these coastal rivers ranged from about 50 to 1,000 (tonnes $/ \mathrm{km}^{2}$ )/yr, with the larger values associated with rivers draining steep mountainous terrain with active tectonic uplift. The lower Puyallup River had a smaller load than the Nisqually River from 1978 to 1994, and, being farther from the source volcano, had a smaller yield of $350 \pm 120$ (tonnes $/ \mathrm{km}^{2}$ ) $/ \mathrm{yr}$. As such, the sediment loads for the Puyallup River from 1978 to 1994 were more comparable to other Pacific Northwest rivers.

\section{Relative Sediment Contributions from Mount Rainier and Other Sources}

Anecdotal observations of active-channel width on rivers crossing from the national park into logged lands outside the park (where no discernible width increases were observed downstream of the park boundary) suggested that most of the sediment load supplied to the rivers draining Mount Rainier originated from the volcano. Assessments of sediment-production potential from this study confirm these anecdotal observations. For example, the contribution to overall sediment load from the Nisqually River basin outside the national park was estimated to be 50,000 $\pm 33,000$ tonnes/yr (table 7). Because the data used to calibrate sediment-production potential were largely based on sediment-load data collected in the 1970s, it is best to compare this estimate to the Nisqually River load estimated between 1956 and 1985, which was determined to be $860,000 \pm 370,000$ tonnes/yr. Using this value as the estimate for the total load during the middle 20th century, then about 83-98 percent of the total sediment load in the upper Nisqually River can be attributed to sources within Mount Rainier National Park. Comparison of the sediment-production potential in the White River basin, which was determined to be $130,000 \pm 89,000$ tonnes/yr, to Dunne's (1986) estimate of sediment load in the upper White River (450,000 tonnes/yr) indicates that about 51-91 percent of the total sediment load in the White River originates from inside the national park. Similarly, comparison of the combined sediment-production potential for the White, Puyallup, and Carbon River basins $(210,000 \pm 150,000$ tonnes/yr) to the sediment load estimate for the lower Puyallup River from 1978 to 1994 (860,000 tonnes/yr) indicates that about 58-93 percent of the total load in the lower Puyallup River can be attributed to sources inside Mount Rainier National Park. No attempt was made to determine the sediment production from specific sources inside the national park (that is, forested areas versus the volcanic cone), but aerial imagery suggested most sediment originates directly from the stratovolcano.

\section{Modeling Bed-Material Sediment Transport by Rivers}

One-dimensional river-hydraulic and sediment-transport models were developed for the Nisqually, Carbon, Puyallup, and White Rivers, simulating the entrainment, transport, abrasion, and deposition of sediment. Major inputs to the models included channel-geometry, streamflow, and sediment data. Results of model simulations were compared to physical measurements, where available, to assess the efficacy of these models in predicting sediment transport at spatial $(0.4-100 \mathrm{~km})$ and temporal (one day to hundreds of years) scales. Model simulations address four questions regarding the quantity, spatial and temporal distribution, downstream effect, and future outlook of sediment transport by rivers draining Mount Rainier: (1) How much sediment is transported by each river and how has this quantity varied through time? (2) How is sediment distributed in space and time through each river as it is transported downstream? (3) What is the timing and magnitude of geomorphic change in downstream reaches due to altered sediment delivery to rivers and varying hydrology? (4) How might changing hydrologic conditions during the next 25-50 years affect bed elevations? 


\section{Model Framework}

Models for each of the four rivers were developed using the Unified Gravel-Sand (TUGS) model with channel-geometry, streamflow, and sediment data as major inputs (Cui, 2007a). A modelconditioning process was used to adjust bed elevations and bed grain-size distributions in order to establish quasi-equilibrium. The upstream extent of each model was chosen where the river had a slope of approximately $0.02 \mathrm{~m} / \mathrm{m}$ to avoid modeling sediment transport on steep slopes and to model reaches of the river where fluvial processes are the dominant mechanism for sediment transport rather than debris flows. For each river, morphodynamic parameters were averaged every $0.4 \mathrm{~km}$ into model nodes. At the downstream end of each model, the bed elevation was fixed and the water-surface elevation was set by the normal flow assumption.

The model of the Nisqually River extended from just upstream of Tahoma Creek to Alder Lake (NRKM 14.2-41.0) and included tributary streamflow and sediment inputs from Big and Mineral Creeks (NRKM 28.2 and 37.4, respectively). The model of the Carbon River extended from Chenuis Creek to the Puyallup River (CRKM 8.2-50.2) and included tributary streamflow and sediment inputs from Evans, South Prairie, and Voight Creeks (CRKM 21.4, 41.4, and 44.2, respectively). The model of the Puyallup River extended from the Mowich River to Commencement Bay of Puget Sound (PRKM 16.2-82.2) and included tributary streamflow and sediment inputs from the Carbon and White Rivers (PRKM 54.2 and 65.8, respectively). The model of the White River extended from within Mount Rainier National Park to the Puyallup River (WRKM 13.4-116.6) and included tributary streamflow and sediment inputs from Huckleberry Creek, West Fork White River, Greenwater River, and Clearwater River (WRKM 33.4, 39.4, 45.0, and 61.8, respectively). Additionally, for the model of the White River downstream of Mud Mountain Dam (WRKM 71.0), the streamflow reflected dam operations.

\section{The Unified Gravel-Sand (TUGS) Model}

The TUGS model (Cui, 2007a) is a one-dimensional river-hydraulic and sediment-transport model that was used to simulate the entrainment, transport, abrasion, and deposition of sediment for each of the four rivers. The major components of the TUGS model include: (1) a flow calculation, which provides local shear stress, through a rectangular channel using a standard-backwater formulation when the Froude number $(F r)$ is less than 0.8 and a quasi-normal flow approximation when $F r$ is greater than or equal to 0.8 ; (2) a local sediment-transport capacity calculation from local shear stress using the surface-based bedload equation of Wilcock and Crowe (2003); and (3) a bed-change calculation using the grain-size-based Exner equations of sediment continuity, which includes the abrasion of gravel during transport as proposed by Parker (1991a, 1991b). The full details of the TUGS model are provided in Cui (2007a). The TUGS model has been used to examine the dynamics of grain-size distributions of gravel/sand deposits in the Sandy River, Oregon (Cui, 2007b), and to predict changes to the sediment transport regime of the Waipaoa River, New Zealand, that may occur in response to forecasted climate changes in the 21 st century (Gomez and others, 2009).

\section{Geomorphic Data}

The major geomorphic data inputs to the TUGS models included channel-geometry, streamflow, and sediment data. The channel-geometry data included channel widths and elevations. The streamflow data were obtained from USGS streamflow-gaging stations and the data were scaled for use upstream and downstream of the gaging-station locations. The sediment data included surface and subsurface sediment grain-size distributions and sediment loads. 


\section{Channel Geometry}

The active channel, defined as the section of the river corridor relatively free of vegetation that conveys the majority of the water and sediment during high flow, was digitized from the 2009 National Agricultural Imagery Program (NAIP) imagery at 1:3000 scale (U.S. Department of Agriculture, 2011). Areas of dense vegetation within the bounds of the active channel were digitized as island features and did not count towards the computation of active-channel width. Mapping of channel features was affected by the quality and resolution of available imagery. Some areas of imagery had varying degrees of glare, shadows, or local obstructions of channel features, and errors were introduced by imprecise line placement. To minimize errors and increase the overall precision of the interpretive mapping, all delineated features were quality controlled by other members of the project team. A river centerline was digitized through the center of the active channel, representing the dominant pathway of the river during high flow. The active-channel width for each 400-m node was computed by dividing the total activechannel area in a given node by the length of the segment $(400 \mathrm{~m})$. Active-channel widths were not altered in the model-conditioning process or in any model simulations.

A longitudinal profile approximating the water-surface elevation was generated by sampling the elevation of LiDAR data along the river centerline. Elevation points were sampled from the underlying LiDAR data at 10-m increments along the river centerlines and averaged every $400 \mathrm{~m}$ to determine an average elevation for each model node. The available LiDAR data sets (appendix A, table A1) were projected and converted to the North American Datum of 1983 (NAD 83) Universal Transverse Mercator zone 10 (UTM 10) in meters and the North American Vertical Datum of 1988 (NAVD 88) in meters. For elevations of the lower $10.5 \mathrm{~km}$ of the Puyallup River and lower $2.5 \mathrm{~km}$ of the White River, channel-elevation data surveyed by Czuba and others (2010) were used because the LiDAR data in these areas represent low-slope backwater conditions that were not representative of the channel slope.

\section{Streamflow Data}

Long-term streamflow records for each river were compiled using time series of daily discharge from USGS streamflow-gaging stations (table 1). The streamflow data measured at gages were scaled to upstream and downstream reaches using 2-year recurrence-interval peak discharges (table 9; U.S. Geological Survey, 2011). Missing streamflow data from Carbon River near Fairfax gage, for WYs 1978-1991, were estimated by multiplying streamflow data from the Puyallup River near Orting gage by 0.6 , which is the average ratio of the streamflows from the two gages during the period when both gages were operating. Streamflow data for the Puyallup River between the Carbon and White Rivers (PRKM 54.2-65.4) were obtained by adding the streamflow data from the Puyallup River near Orting gage to 1.65 times the streamflow data from the Carbon River near Fairfax gage (sum of streamflows above the confluence of the Puyallup and Carbon River; table 9). Streamflow data for the White River downstream of Mud Mountain Dam (WRKM 71.0-116.6) were derived using data from a combination of the White River near Buckley gage, for WYs 1939-2003, and the White River above Boise Creek at Buckley gag, for WYs 2004-2011 (table 9).

\section{Sediment Data}

All sediment data were grouped into discrete size ranges, with breaks between ranges defined using the sedimentological phi-scale $(2,4,8,16,32,64,128,256,512$, and 1,024 mm). The grain-size distribution for sand and fines had a median particle size (D50) of approximately $0.4 \mathrm{~mm}$, was assumed to be identical everywhere, and was based on physical measurements of the sand distribution in the lower Puyallup River system (Czuba and others, 2010). The volumetric abrasion coefficient for coarse sediment (greater than $2 \mathrm{~mm}$ ) was set at $0.02 / \mathrm{km}$ based on abrasion values for basaltic colluvium from 
the Satsop River basin in the southern Olympic Mountains in Washington State (Collins and Dunne, 1989).

Surface grain-size distributions were measured using the Wolman pebble-count method (Wolman, 1954) between October 2010 and August 2011 (NRKM 2-41.0, CRKM 2-25, PRKM 8-22, and WRKM 4-93) and also were obtained from previous studies (Czuba and others, 2010: CRKM 3850.2, PRKM 36-82.2, and WRKM 110-116.6; Herrera Environmental Consultants, 2010: WRKM 100109). Surface grain-size distributions measured at each site were assigned to the nearest model node and were used to interpolate grain-size distributions for all other nodes.

The distribution of sediment load by grain size, which varied with streamflow, was input to the model at the upstream boundary and at tributaries and was determined using the software program Bedload Assessment in Gravel-bedded Streams (BAGS; Pitlick and others, 2009). BAGS computed bedload transport by grain size for a range of flows using the Wilcock and Crowe (2003) bedloadtransport equation from channel-width, slope, surface grain-size distribution, and streamflow data at the input location. The TUGS model was modified to supply sediment by grain size at the input location using the BAGS output and streamflow data.

The subsurface grain-size distribution at each node was computed by combining 30 percent of the surface grain-size distribution with 70 percent of the bedload grain-size distribution (from BAGS) following the formulation of Toro-Escobar and others (1996). The subsurface sand fraction was set equal to the surface sand fraction. Sand covered the bed of the lower Puyallup and White Rivers (PRKM 75.8-82.2 and WRKM 111.0-116.6) when the bed material was measured by Czuba and others (2010). The TUGS model is capable of modeling a sand-covered bed (Cui, 2007a, 2007b; Gomez and others, 2009). However, the downstream boundary conditions (tidal water-surface elevation for the Puyallup River and the Puyallup River water-surface elevation for the White River) required to maintain a sandcovered bed were simplified to normal flow water-surface elevations resulting in inaccuracies for the downstream end of the Puyallup and White River models.

\section{Model-Conditioning Process}

The model-conditioning process allowed imprecise bed elevations and bed grain-size distributions to adjust until model output stabilized at a quasi-equilibrium condition. The modelconditioning process also has been referred to as a zero process and is discussed further by Cui and Wilcox (2008) and Cui and others (2006a, 2006b). First, input sediment loads from BAGS were reduced until the long-term bed-elevation change was minimized at the upstream model boundary and at tributaries. Second, the entire long-term streamflow record was simulated repeatedly with bed elevations (and therefore local slope) and grain-size distributions from the end of one simulation used as input to the next simulation. Model simulations were repeated until each model reached quasi-equilibrium, when the model simulated short-term fluctuations in bed elevation, but minimal long-term change. At the end of the model-conditioning process, the general downstream variation of the model-conditioned (or simulated) slope and grain-size distribution matched the raw-input (or measured) data, but the modelconditioned slope and grain-size distribution were locally adjusted. The conditioned models define the geomorphic starting point for all simulations.

\section{Geomorphic Setting}

The geomorphic setting of the Nisqually, Carbon, Puyallup, and White Rivers can be described by the channel-geometry and bed-sediment characteristics of these rivers. The primary geomorphic variables describing the channel geometry are the model-conditioned (or simulated) slope and raw-input 
(or measured) width. The primary geomorphic variables describing the bed sediment are the modelconditioned (or simulated) D50 size, D90 size, and percent sand of bed-surface sediment.

\section{Nisqually River}

The Nisqually River (NRKM 14.2-41.0) was characterized by three geomorphic reaches: an upper alluvial reach (NRKM 14.2-28.2), a constricted reach (NRKM 28.6-32.6), and a lower alluvial reach (NRKM 33.0-41.0) (fig. 30). The Nisqually River (NRKM 14.2-41.0) had a slope that decreased from approximately 0.02 to $0.008 \mathrm{~m} / \mathrm{m}$ and a width that varied between 150 and $250 \mathrm{~m}$. There were two short constrictions in the width of the Nisqually River between NRKM 28.6 and 32.6 that were associated with a local decrease in slope. The model-conditioned D90 size, D50 size, and percent sand of bed-surface sediment decreased from approximately 160 to $100 \mathrm{~mm}, 60$ to $40 \mathrm{~mm}$, and increased from approximately 40 to 60 percent, respectively. The model-conditioned D90 and D50 sizes of bedsurface sediment were smaller than measured data and the model-conditioned percent sand of bedsurface sediment was within the variability of the measured data.

\section{Carbon River}

The Carbon River (CRKM 8.2-50.2) was characterized by three geomorphic reaches: an upper alluvial reach (CRKM 8.2-20.2), a canyon reach (CRKM 20.6-37.0), and a lower alluvial reach (CRKM 37.4-50.2) (fig. 31). The upper alluvial reach (CRKM 8.2-20.2) had a slope that gradually decreased from 0.02 to $0.015 \mathrm{~m} / \mathrm{m}$ and a width that varied between 150 and $300 \mathrm{~m}$. The active channel was more than $400 \mathrm{~m}$ wide at CRKM 10.6. The canyon reach (CRKM 20.6-37.0) was constrained by a bedrock canyon to a width of approximately $30 \mathrm{~m}$. The lower alluvial reach (CRKM 37.4-50.2) had a slope that decreased from 0.01 to $0.004 \mathrm{~m} / \mathrm{m}$ and a width that varied between 60 and $180 \mathrm{~m}$. The modelconditioned D90 size, D50 size, and percent sand of bed-surface sediment decreased from approximately 200 to $120 \mathrm{~mm}, 80$ to $60 \mathrm{~mm}$, and increased from approximately 20 to 30 percent, respectively, and generally were within the variability of the measured data.

\section{Puyallup River}

The Puyallup River (PRKM 16.2-82.2) was characterized by four geomorphic reaches: an upper alluvial reach (PRKM 16.2-21.0), a canyon reach (PRKM 21.4-33.4), a middle alluvial reach downstream of the canyon (PRKM 33.8-48.2), and a lower alluvial reach downstream of Calistoga Street (PRKM 48.6-82.2) (fig. 32). The upper alluvial reach (PRKM 16.2-21.0) had a slope of approximately $0.017 \mathrm{~m} / \mathrm{m}$ and a width that increased from approximately 60 to $200 \mathrm{~m}$. The canyon reach (PRKM 21.4-33.4) was constrained by a bedrock canyon to a width of approximately $30 \mathrm{~m}$. The middle alluvial reach downstream of the canyon (PRKM 33.8-48.2) had a slope that decreased from 0.01 to $0.005 \mathrm{~m} / \mathrm{m}$ and a width that varied between 100 and $200 \mathrm{~m}$. The narrow width of $45 \mathrm{~m}$ at PRKM 41.0 corresponds to the bedrock constriction at the Puyallup River near Orting gage (12093500), and the wide section at PRKM 42.6 of 280 m corresponding to the setback-levee reach (Czuba and others, 2010). The lower alluvial reach downstream of Calistoga Street (PRKM 48.6-82.2) had a slope that decreased from 0.005 to $0.0006 \mathrm{~m} / \mathrm{m}$ and a width that generally varied between 40 and $100 \mathrm{~m}$. The model-conditioned D90 size, D50 size, and percent sand of bed-surface sediment decreased from approximately 430 to $60 \mathrm{~mm}, 180$ to $35 \mathrm{~mm}$, and increased from approximately 25 to 50 percent, respectively, and generally were within the variability of the measured data except for the percent sand downstream of PRKM 50.0. 


\section{White River}

The White River (WRKM 13.4-116.6) was characterized by four geomorphic reaches: an upper alluvial reach (WRKM 13.4-44.6), a middle alluvial reach separated into two reaches upstream and downstream of Mud Mountain Dam (WRKM 45.0-70.6; 71.0-101.0, respectively), and a lower alluvial reach (WRKM 101.4-116.6) (fig. 33). The upper alluvial reach (WRKM 13.4-44.6) had a slope that decreased from 0.02 to $0.01 \mathrm{~m} / \mathrm{m}$ and a width that generally varied between 50 to $150 \mathrm{~m}$. The Greenwater River joined the White River at the upstream end of the middle alluvial reach (WRKM 45.0-101.0), which had a nearly constant slope of $0.008 \mathrm{~m} / \mathrm{m}$ and a width that generally varied from 50 to $150 \mathrm{~m}$. The lower alluvial reach (WRKM 101.4-116.6) had a slope that decreased from 0.008 to $0.002 \mathrm{~m} / \mathrm{m}$ and a width of approximately $50 \mathrm{~m}$. The model-conditioned slope of the White River was larger than the raw input between WRKM 111.0-116.6 because the tendency of the model, during the model-conditioning process, was to increase the slope of the river in order to more efficiently transport sediment through this reach. The model-conditioned D90 size, D50 size, and percent sand of bedsurface sediment decreased from approximately 140 to $55 \mathrm{~mm}, 60$ to $25 \mathrm{~mm}$, and generally varied between 30 and 40 percent, respectively, and generally were within the variability of the measured data except for the percent sand downstream of WRKM 45.0.

\section{Model Performance}

Model performance was assessed based on a comparison of simulated sediment loads to physical measurements. In addition to these comparisons, the limitations of the models are discussed to aid in the interpretation of model results.

\section{Model Comparison to Physical Measurements}

The Nisqually River deposits its bed-material load (sand, gravel, and cobbles) in the delta of the Nisqually River in Alder Lake. The finer washload (silt and clay) is either deposited in the main body of Alder Lake or transported through the dam outlet. Changes in the volume of sediment deposited in the delta of the Nisqually River in Alder Lake were estimated between 1945 and 1956, 1985, and 2011 by Czuba and others (2012). A simulation of the conditioned Nisqually River model between WYs 1946 and 2011 shows that the simulated sediment loads of the Nisqually River into Alder Lake were within the uncertainty bounds of the measurements of changes in delta volume (table 10). The model of the Nisqually River tended to simulate slightly higher transport into Alder Lake than was measured, except for WYs 1946-1956, which was attributed to the 1947 Kautz Creek debris flow that was not incorporated into the model simulations.

Concurrent measurements of suspended load and bedload from the Carbon River at State Route 162/Pioneer Way, Puyallup River at Calistoga Street, and White River at R Street were compared to model-simulated loads. Measured loads were separated into a sand load (sum of the fraction less than 2 $\mathrm{mm}$ from the suspended load and bedload samples) and a gravel load (fraction greater than $2 \mathrm{~mm}$ from the bedload samples) for comparison to model simulations of sand load and gravel load because the Wilcock and Crowe (2003) equation (used in the TUGS model) simulates the transport of sand and gravel as bed-material load. Bed-material load is the fraction of the total sediment load affecting bed elevations, which is the focus of this study. For comparison, the simulated loads in $\mathrm{m}^{3} / \mathrm{d}$ were converted to tonnes/d assuming a density of 1.6 tonnes $/ \mathrm{m}^{3}$ (Wu and Wang, 2006).

The measurements of sediment load were made during two periods: 1986 and 2010-2011. The simulated loads in comparison to the measured loads generally were in good agreement for the combined sand and gravel, and sand (fig. 34). The model overpredicted gravel load at low loads 
compared to the measured loads (fig. 34), which in part may be due to the timing of the physical measurements on the falling limb of the hydrograph.

\section{Model Limitations}

The comparisons of the simulated loads to physical measurements provide a measure of the accuracy of the models at predicting sediment loads, and ultimately model performance. In order to fully understand the model results, this section discusses some of the limitations inherent in the TUGS model itself and in the model as applied to the Nisqually, Carbon, Puyallup, and White Rivers.

It is difficult to assess the efficacy of the models based on a few measurements. Additionally, for the sediment-load measurements, the appropriateness of the comparisons of the measured data to the simulated results are uncertain, given their different spatial and temporal resolutions. For each measurement, several samples were collected at 5-20 points along a cross section of the river, each sample was collected over several seconds, and the resulting samples were combined to obtain a rate of sediment transport. Measurements at high-streamflow conditions often occur when the flow is rapidly changing with the streamflow rising, peaking, and receding all within a day. In the model, each node represents the average conditions over a bed area that is an active-channel-width wide by 400-m long. Therefore, any change in elevation at a node represents the average change over this area, which can vary significantly within this area. For example, the measured change in elevation from 1984-2009 at one cross section on the Puyallup River was between $-1 \mathrm{~m}$ and $3 \mathrm{~m}$, with an average elevation increase of approximately $1 \mathrm{~m}$ (cross section P120 in Czuba and others 2010). The model also used daily streamflow, which underestimates peak streamflows, and averages out any variation in streamflow within a day.

The active-channel widths were fixed for all model simulations. The widths, measured from the 2009 aerial imagery, were likely larger than the long-term average active-channel widths due to recent large flows (fig. 11). Though past and future hydrologic conditions were simulated with fluctuating sediment loads, bed elevations, and hydrology, fixed channel widths limited the models' predictive accuracy relative to some of the dynamics of sediment transport through time. Additionally, for all model simulations, streamflow and sediment were confined to the active channel, and the models did not simulate overbank flow or conveyance through the vegetated flood plain. Improved models would account for these factors.

The model-conditioning process established quasi-equilibrium conditions for these rivers as a starting point for model simulations. However, some reaches may not be in quasi-equilibrium, whereby they are storing sediment locally and not efficiently transporting sediment downstream (such as in setback-levee reaches). Additionally, any modifications to various reaches in the future that were not considered in the future model simulations would violate the quasi-equilibrium assumption (such as setback levees and gravel removal implemented after 2009). In particular, the conditioning process significantly changed the slope of the lower White River near Auburn from its current low-slope value to a relatively steep future condition. As a result of the conditioning, the model poorly predicts longterm aggradation along the lower White River.

The downstream boundary conditions (water-surface elevations) required to maintain a sandcovered bed of the lower Puyallup and White Rivers (PRKM 75.8-82.2 and WRKM 111.0-116.6) were simplified to normal flow water-surface elevations in the model simulations, and, therefore, simulated changes in bed elevations in these reaches are not accurate. Furthermore, the significant increase in the model-conditioned slope from the measured slope of the lower White River (WRKM 111.0-116.6) highlights that this reach does not effectively transport sediment downstream, implying that sediment 
deposits just upstream of and within this reach. Model simulations were not accurate for this reach of the lower White River.

The model of the White River simplifies the dynamics of the transport through Mud Mountain Dam. In the model, there is a change in streamflow at Mud Mountain Dam where water and sediment freely passes through a channel-width constriction of $40 \mathrm{~m}$. The model simulates sediment passing immediately through, instead of temporarily accumulating in and later sluicing out of the reservoir. It was assumed that most sediment is sluiced through the reservoir between winter storms or during spring and summer snowmelt; therefore, the transport of sediment through the reservoir is only delayed a few months, which would not significantly affect annual sediment loads downstream. However, it is currently unknown how effective Mud Mountain Dam has been at trapping sediment since its construction in 1948 and how this trap efficiency might have changed over time.

Another limitation of the models is that they do not account for additional sediment load supplied by channel migration into flood plain deposits or glacial-till bluffs. The erosion of sediment from the toe of glacial-till bluff can be significant, particularly along the lower Carbon River.

Given these limitations, the models generally were able to simulate predicted loads and were able to provide insight into questions regarding the quantity, spatial and temporal distribution, downstream effect, and future outlook of sediment transport by rivers draining Mount Rainier.

\section{Model Simulations of the Nisqually, Carbon, Puyallup, and White Rivers}

Model simulations address four questions regarding sediment transport by rivers draining Mount Rainier: (1) How much sediment is transported by each river and how has this quantity varied through time? (2) How is sediment distributed in space and time through each river as it is transported downstream? (3) What is the timing and magnitude of geomorphic change in downstream reaches due to altered sediment delivery to rivers and varying hydrology? (4) How might changing hydrologic conditions during the next 25-50 years affect bed elevations?

\section{Model Simulation of Long-Term Streamflow Record}

A simulation of the long-term streamflow record for each river provides an estimate of sediment transport by each river and how this quantity might have varied through time. Daily streamflow and simulated annual bed-material sediment load for each river are shown for the Nisqually River at State Route 7 (NRKM 41.0), Carbon River at State Route 162/Pioneer Way (CRKM 41.0), Puyallup River at Calistoga Street (PRKM 48.6), and White River at R Street (WRKM 104.6) (fig. 35). At these locations, average-annual streamflow was largest to smallest for the Nisqually, White, Puyallup, and Carbon Rivers. Streamflow of the White River was not as variable as streamflow of the other rivers because the White River at R Street location is downstream of Mud Mountain Dam, which moderates peak streamflow. Similar to streamflow, the simulated annual bed-material sediment load was largest for the Nisqually River $\left(690,000 \mathrm{~m}^{3} / \mathrm{yr}\right)$ and was smaller for the White $\left(530,000 \mathrm{~m}^{3} / \mathrm{yr}\right)$, Puyallup $(83,000$ $\mathrm{m}^{3} / \mathrm{yr}$ ), and Carbon $\left(15,000 \mathrm{~m}^{3} / \mathrm{yr}\right.$ ) Rivers (table 11$)$. The simulated bed-material sediment loads ranged over an order of magnitude: $340,000-1,500,000 \mathrm{~m}^{3} / \mathrm{yr}$ for the Nisqually; $2,800-77,000 \mathrm{~m}^{3} / \mathrm{yr}$ for the Carbon; 28,000-260,000 $\mathrm{m}^{3} / \mathrm{yr}$ for the Puyallup; and 250,000-900,000 $\mathrm{m}^{3} / \mathrm{yr}$ for the White Rivers (table 11). Streamflow is the driving force of sediment transport and the differences between streamflows explain the differences between sediment loads for these rivers. The simulated annual bed-material sediment load was, on average, 8, 16, 8, and 16 percent gravel and coarser for the Nisqually, White, Puyallup, and Carbon Rivers, respectively (table 11). This suggests that of the sediment measured in the delta of the Nisqually River in Alder Lake, 8 percent is gravel and coarser sediment. 


\section{Capacity of Rivers to Transport Sediment}

Locations along rivers that are most prone to sedimentation are those where the capacity of the river to move sediment decreases. Two metrics for characterizing the ability of rivers to move sediment are sediment-transport capacity and stream power (figs. 36-39). Sediment-transport capacity $\left(\mathrm{m}^{3} / \mathrm{d}\right)$ directly quantifies the amount of bed-material sediment that can be transported by the river for a given flow and was calculated for the 2-year recurrence-interval flow (table 11; U.S. Geological Survey, 2011). Stream power is the rate at which energy is expended per unit downstream length by the flowing water. Stream power $(\Omega$; watts $[\mathrm{W}] / \mathrm{m})$ was computed as:

\section{$\Omega=\rho g Q S$,}

where $\rho$ is the density of water $\left(1,000 \mathrm{~kg} / \mathrm{m}^{3}\right), \mathrm{g}$ is the acceleration due to gravity $\left(9.81 \mathrm{~m} / \mathrm{s}^{2}\right), \mathrm{Q}$ is the 2-year recurrence-interval streamflow $\left(\mathrm{m}^{3} / \mathrm{s}\right)$, and $\mathrm{S}$ is the local river slope $(\mathrm{m} / \mathrm{m})$. Additionally, dividing the sediment-transport capacity and stream power by the active-channel width (referred to as unit sediment-transport capacity $\left[\left(\mathrm{m}^{3} / \mathrm{d}\right) / \mathrm{m}\right]$ and unit stream power, respectively) shows the strength of the river acting on a unit area to transport sediment (figs. 36-39). Unit stream power $\left(\omega ; \mathrm{W} / \mathrm{m}^{2}\right)$ was computed as:

$\omega=\Omega / \mathrm{B}=\rho \mathrm{gQS} / \mathrm{B}$,

where $\mathrm{B}$ is the local active-channel width (m).

Sediment-transport capacity and stream power quantify the strength of the river acting on the bed of the river, irrespective of how the channel width concentrates these forces on the bed. Unit sediment-transport capacity and unit stream power quantify the strength of the river acting on a unit area of the bed, and for the same sediment-transport capacity or stream power, the unit metrics identify where the strength of the river is high due to a narrow channel or low due to a wide channel. Reaches with low sediment-transport capacity and stream power are reaches that are prone to sedimentation. Reaches with low unit sediment-transport capacity and unit stream power are weak at transporting sediment per unit bed area.

The capacity of the Nisqually River to transport sediment decreased in the upper alluvial reach (NRKM 14.2-28.2) to a minimum at NRKM 28.2, was variable in the constricted reach (NRKM 28.632.6), and was greater in the lower alluvial reach (NRKM 33.0-41.0) than in the upper alluvial reach (fig. 36). The lower alluvial reach of the Nisqually River is downstream of Mineral Creek, which is tributary to the Nisqually River, and therefore increases the capacity of the river to transport sediment. The strength of the Nisqually River to transport sediment per unit width was lowest between NRKM 21.8 and 28.2 and highest in the constricted reach (NRKM 28.6-32.6) (fig. 36).

The capacity of the Carbon River to transport sediment was lowest in the upper alluvial reach (CRKM 8.2-20.2), slightly higher in the lower alluvial reach (CRKM 37.4-50.2), and highest in the canyon reach (CRKM 20.6-37.0) (fig. 37). The strength of the Carbon River to transport sediment per unit width was lowest at CRKM 10.6 where the active channel width was widest and exhibited similar patterns as the capacity of the Carbon River to transport sediment (fig. 37).

The capacity of the Puyallup River to transport sediment generally decreased downstream (PRKM 16.2-82.2) except for the canyon reach (PRKM 21.4-33.4) where the capacity was highest (fig. 38). The lowest capacity at PRKM 65.4 was just upstream of the confluence with the White River (fig. 38). The strength of the Puyallup River to transport sediment per unit width locally was low at PRKM 42.6, a setback-levee reach (Czuba and others, 2010). Elsewhere along the Puyallup River, the stream power per unit width exhibited similar patterns to transport sediment (fig. 38).

The capacity of the White River to transport sediment decreased in the upper alluvial reach (WRKM 13.4-44.6), increased in the middle alluvial reach upstream of Mud Mountain Dam (WRKM 45.0-70.6), decreased in the middle alluvial reach downstream of Mud Mountain Dam (WRKM 71.0- 
101.0), and decreased most significantly in the lower alluvial reach (WRKM 101.4-116.6) (fig. 39). The strength of the White River to transport sediment per unit width was lowest throughout most of the upper alluvial reach (WRKM 13.4-44.6), just upstream of the confluence with the Clearwater River (WRKM 54.6-61.8), and throughout the lower alluvial reach (WRKM 101.4-116.6) (fig. 39).

\section{Spatial and Temporal Geomorphic Change due to Altered Sediment Supply}

A set of model simulations were used to assess the timing and magnitude of geomorphic change in downstream reaches due to altered sediment supply and varying hydrology, and to assess how sediment is distributed in space and time through each river as it is transported downstream. Model simulations were used to investigate how increases in sediment supply to rivers, as pulses distributed during the first year of simulation, are transported through the river systems and affect lowland reaches. The set of model simulations for each river consisted of 36 different conditions: 3 hydrologic conditions, 2 pulse volumes, and 6 pulse grain sizes. The set of model simulations had varied hydrology [repeating 10-year periods of daily discharge of high (WYs 1995-2004), medium (WYs 1975-1984), and low (WYs 1985-1994) flow], pulse volume (100,000 and 500,000 $\mathrm{m}^{3}$ supplied to the upstream end of the model throughout the first simulation year), and pulse grain size (uniform distribution where 100 percent is finer than $4,8,16,32$, and $64 \mathrm{~mm}$, and a distribution of sand; generally all sizes were less than the D50 bed-surface grain size). For each hydrologic condition, simulated results of bed elevations/volumes and sediment loads of a baseline condition (without an input sediment pulse) were subtracted from the simulated results of a sediment-pulse condition (with different pulse volumes and grain size) to isolate the response of the input sediment pulse.

For each simulation, the input sediment pulse evolved through a combination of translation, dispersion, and attrition as it moved down the river system. A characteristic time for each pulse to arrive at each location along the river was computed as the time for half of the pulse to transport past that location, specifically, the median of the cumulative distribution of the increase in sediment load at each location through time. The magnitude of geomorphic change at each location along each river due to the input sediment pulse was quantified as the maximum increase through time in bed volume and sediment load compared to the baseline condition.

The characteristic transport time for each simulated pulse to move through the river depended strongly on the grain size of the pulse compared to that of the bed surface (normalized grain size). Sediment pulses finer than the D50 of the bed surface transport faster than pulses that are more similar to the D50 of the bed surface, and pulses coarser than the D50 of the bed surface transport slower with in-place attrition dominating pulse evolution (Cui and others, 2003; Cui and Parker, 2005; Sklar and others, 2009). The characteristic transport time, change in sediment load, and change in bed volume for each pulse condition was summarized for each river at one location: Nisqually River at State Route 7 (NRKM 41.0), Carbon River at State Route 162/Pioneer Way (CRKM 41.0), Puyallup River at Calistoga Street (PRKM 48.6), and White River at R Street (WRKM 104.6) (fig. 40).

As the pulse grain size gets larger, it takes longer to transport this sediment downstream because fewer events occur that are capable of transporting this sediment, and when this sediment arrives downstream, the increased sediment load is smallest for the largest size classes. The influence of pulse grain size on bed volume locally varies, with no clear trend at the one summary location for each river. As the pulse volume increases, it takes longer to transport this sediment downstream because more sediment needs to be moved before half of the pulse is transported, and the bed volume and sediment load increases because there is more sediment that can ultimately deposit and transport as the sediment moves downstream. As the magnitude or frequency of sediment-transporting streamflow increases, 
sediment transports downstream quicker and the loads are larger. The influence of streamflow on bed volume is small compared to other factors, with no clear trend at these locations.

The characteristic transport time for the D50 sediment size to arrive at a downstream location for the Nisqually River at State Route 7, Carbon River at State Route 162/Pioneer Way, Puyallup River at Calistoga Street, and White River at R Street is approximately 70, 300, 80, and 60 years, respectively (fig. 41). For this reason, increased sediment input to the upper rivers beginning in 1967 (Copeland, 2009) would have affected the Puget Lowland sooner in the Puyallup River than the Carbon River, which may explain the pattern of average channel-elevation change between 1984 and 2009 measured by Czuba and others (2010, fig. 10).

The characteristic transport time (fig. 41) is a cumulative function of the time it takes for a sediment pulse to arrive downstream, which integrates the travel time of the pulse through upstream reaches. The difference in the characteristic transport times between downstream and upstream model nodes yields the characteristic residence time of the pulse through each 400-m node. Each sedimentpulse simulation (36 for each river) shows similar reaches with high and low residence times, but the absolute values scale with grain size. Because the characteristic residence time of the sediment pulse strongly depends on the grain size of the pulse, the characteristic residence time of all pulse simulations was normalized to the characteristic D50 sediment size of the bed-surface sediment by dividing the characteristic residence time by the pulse grain size and multiplying it by the D50 of the bed-surface sediment. The 36 normalized characteristic residence times for each river were averaged (figs. 42a-45a) and show the characteristic time for sediment to move through each $400-\mathrm{m}$ node as the sediment is locally stored and transported downstream. The light-gray lines are the average value plus or minus one standard deviation of the 36 normalized characteristic residence times for each river (figs. 42a-45a).

The characteristic residence time for the Nisqually River was long in the upper alluvial reach (NRKM 14.2-28.2) at approximately 1 year, and longest between NRKM 21.8 and 28.2 at approximately 1.1 year (fig. 42A). The constricted reach (NRKM 28.6-32.6) had the shortest residence time at the constriction because this reach is capable of quickly transporting sediment downstream (fig. 42A). The lower alluvial reach (NRKM 33.0-41.0) had a residence time of approximately 0.7 year, which was shorter than in the upper alluvial reach (fig. 42A).

The characteristic residence time for the Carbon River was longest in the upper alluvial reach (CRKM 8.2-20.2) at approximately 38 years, with a maximum residence time of 113 years at CRKM 10.2 (fig. 43A). The canyon reach (CRKM 20.6-37.0) was capable of transporting sediment downstream quickly, with a residence time near zero for sediment (fig. 43A). The lower alluvial reach (CRKM 37.4-50.2) had a residence time of approximately 7 years, which was highest just downstream of the canyon (CRKM 37.4-41.0) and decreased farther downstream (CRKM 41.4-50.2) (fig. 43A).

The characteristic residence time for the Puyallup River in the upper alluvial reach (PRKM 16.2-21.0) was approximately 2.8 years (fig. 44A). The canyon reach (PRKM 21.4-33.4), like the canyon reach of the Carbon River (CRKM 20.6-37.0), was capable of transporting sediment downstream quickly and had a minimal residence time (fig. 44A). The middle alluvial reach downstream of the canyon (PRKM 33.8-48.2) had a residence time of approximately 4.3 years, and was longest at PRKM 42.2 at approximately 8.7 years (fig. 44A). The lower alluvial reach downstream of Calistoga Street (PRKM 48.6-82.2) had a residence time of approximately 3.1 years (fig. 44A).

The characteristic residence time for the White River was longest in the upper alluvial reach (WRKM 13.4-44.6) at approximately 0.5 years (fig. 45A). Where the Greenwater River enters the White River in the middle alluvial reach (WRKM 45.0-101.0), the residence time was reduced to approximately 0.2 years as the White River was more competent to transport sediment (fig. 45a). The lower alluvial reach (WRKM 101.4-116.6) had a residence time of approximately 0.5 years (fig. 45A). 
The large spike near WRKM 71.0 is a discontinuity in the model at Mud Mountain Dam and does not represent a real response in the river.

The maximum increase in bed volume from each sediment pulse input was divided by the pulse volume because pulse volume had the greatest influence on bed-volume change. The maximum increase in bed volume normalized by the pulse volume shows what percentage of the original pulse volume will temporarily deposit at each model node as the sediment moves downstream (figs. 42b-45b). The greatest changes in bed volume due to the pulse inputs were closest to the input location, and generally decreased downstream. In general, the maximum increase in bed volume due to the sediment-pulse input was on the order of a few percent of the input-pulse volume for the lowland reaches of each river.

The maximum increase in bed volume, owing to the sediment-pulse input, for the Nisqually River was greatest in the upper alluvial reach (NRKM 14.2-28.2) at approximately 12 percent. The maximum increase in bed volume in the constricted reach (NRKM 28.6-32.6) was approximately 2.3 percent. The lower alluvial reach (NRKM 33.0-41.0) had maximum increases in bed volume of approximately 2 percent (fig. 42B).

The maximum increase in bed volume, owing to the sediment-pulse input, for the Carbon River was greatest in the upper alluvial reach (CRKM 8.2-20.2) at approximately 18 percent, with a maximum between CRKM 8.2 and 10.6 of 50 percent (fig. 43B). The maximum increase in bed volume in the canyon reach (CRKM 20.6-37.0) was near zero as this reach was capable of quickly transporting sediment downstream (fig. 43B). The lower alluvial reach (CRKM 37.4-50.2) had a maximum increase in bed volume of approximately 1.2 percent (fig. 43B).

The maximum increase in bed volume, owing to the sediment-pulse input, for the Puyallup River was greatest in the upper alluvial reach (PRKM 16.2-21.0) at approximately 19 percent (fig. 44B). The canyon reach (PRKM 21.4-33.4), like the canyon reach of the Carbon River (CRKM 20.637.0), was capable of quickly transporting sediment downstream with minimal increase in bed volume (fig. 44B). The middle alluvial reach downstream of the canyon (PRKM 33.8-48.2) had maximum increases in bed volume of approximately 6 percent and farther downstream, the lower alluvial reach downstream of Calistoga Street (PRKM 48.6-82.2) had increases of approximately 1.5 percent (fig. 44B).

The maximum increase in bed volume, owing to the sediment-pulse input, for the White River was greatest in the upper alluvial reach (WRKM 13.4-44.6) at approximately 5.3 percent (fig. 45B). Downstream of the confluence with the Greenwater River, in the middle alluvial reach (WRKM 45.0 101.0), the maximum increase in bed volume, owing to the pulse, was approximately 0.5 percent, and in the lower alluvial reach (WRKM 101.4-116.6) the maximum increase in bed volume was approximately 0.3 percent (fig. 45B).

\section{Potential Effect of Changing Hydrologic Conditions on Future Bed Elevations}

Potential changes in hydrologic conditions during the next 25-50 years were simulated to assess possible future effects on bed elevations. Projections of future climate conditions in Washington State during the 21 st century include increased temperatures, increased precipitation and runoff for OctoberMarch, and decreased precipitation and runoff for April-September (compared with the mean during WYs 1917-2006; Elsner and others, 2010). Potential bed-elevation change was simulated for 50 years for WYs 2010-2059 based on projected changes in runoff from Elsner and others (2010) by repeating the 25-year period of daily streamflow for WYs 1982-2006 during the simulation period. The daily streamflows for the first 25-year period were increased by 11.6 percent for October-March and decreased by 18.1 percent for April-September (Elsner and others, 2010). The daily streamflows for the 
second 25-year period were increased by 18.1 percent for October-March and decreased by 26.3 percent for April-September (Elsner and others, 2010).

The model-conditioning process established a river with geomorphic characteristics that effectively transports sediment through the system with minimal long-term change in bed elevations. As a result, the model is incapable of simulating changes to a river reach undergoing conditions of rapid aggradation or incision. When run under the baseline condition, the conditioned model simulates minimal bed-elevation change after 25 and 50 years (figs. 46-49). The projected future hydrologic conditions were assumed to include a rate of sediment delivery close to the sediment-transport capacity of the upstream end of each river, without excessive aggradation or incision at the upstream end of the model. This assumption was necessary because there is no model of how sediment production from Mount Rainier will change for future climate conditions. The future conditions show potential bedelevation change after 25 and 50 years given the projected changes in streamflow resulting from changes in climate conditions (figs. 46-49). It is uncertain how the supply of sediment will change with changing streamflow, increased temperatures, and increased storm intensity. Therefore, a sensitivity analysis of the change in potential bed elevation due to the altered streamflow was included by simulating both a 10-percent increase and decrease in sediment supply.

For the Nisqually River, the average difference in bed elevations between a 10-percent increase and decrease in sediment supply was $0.7 \mathrm{~m}$ after 50 years (fig. 46). The locations where bed-elevation changes were predicted to be the greatest are NRKM 14.6-18.6 with deposition of approximately 0.18 and $0.41 \mathrm{~m}$ of sediment after 25 and 50 years, respectively, compared to approximately 0.07 and $0.08 \mathrm{~m}$ for the baseline condition, respectively; and NRKM 24.2-31.0 with deposition of approximately 0.16 and $0.39 \mathrm{~m}$ after 25 and 50 years, respectively, compared to incision of approximately 0.01 and $0 \mathrm{~m}$ for the baseline condition, respectively.

For the Carbon River, the average difference in bed elevations between a 10-percent increase and decrease in sediment supply was $0.04 \mathrm{~m}$ after 50 years (fig. 47). Bed-elevation changes of the Carbon River 25 and 50 years into the future were predicted to be minimal. The locations where bedelevation changes were predicted to be the greatest are CRKM 15.8-17.8 with deposition of approximately 0.03 and $0.05 \mathrm{~m}$ of sediment after 25 and 50 years, respectively, compared to approximately 0.02 and $0.03 \mathrm{~m}$ for the baseline condition, respectively; CRKM 37.4-41.4 with incision of approximately 0.05 and $0.11 \mathrm{~m}$ after 25 and 50 years, respectively, compared to approximately 0.06 and $0.10 \mathrm{~m}$ for the baseline condition, respectively; and CRKM 46.6-50.2 with deposition of approximately 0.0 and $0.03 \mathrm{~m}$ after 25 and 50 years, respectively, compared to incision of approximately 0.04 and $0.05 \mathrm{~m}$ for the baseline condition, respectively.

For the Puyallup River, the average difference in bed elevations between a 10-percent increase and decrease in sediment supply was $0.14 \mathrm{~m}$ after 50 years (fig. 48). The locations where bed-elevation changes were predicted to be the greatest are PRKM 39.4-82.2 with deposition of approximately 0.10 and $0.21 \mathrm{~m}$ of sediment after 25 and 50 years, respectively, compared to approximately 0.04 and $0.06 \mathrm{~m}$ for the baseline condition, respectively.

For the White River, the average difference in bed elevations between a 10-percent increase and decrease in sediment supply was 1.96 m upstream of Mud Mountain Dam (WRKM 71.0) (fig. 49). The locations where bed-elevation changes were predicted to be the greatest were WRKM 25.8-52.2 with deposition of approximately 0.22 and $0.56 \mathrm{~m}$ of sediment after 25 and 50 years, respectively, compared to incision of approximately 0.09 and $0.16 \mathrm{~m}$ for the baseline condition, respectively; WRKM 53.4-67.0 with deposition of approximately 0.47 and $0.86 \mathrm{~m}$ after 25 and 50 years, respectively, compared to approximately 0.04 and $0.02 \mathrm{~m}$ for the baseline condition, respectively; and WRKM 71.4-82.2 with deposition of approximately 0.31 and $0.44 \mathrm{~m}$ after 25 and 50 years, respectively, compared to 
approximately 0.19 and $0.21 \mathrm{~m}$ for the baseline condition, respectively. Results are not shown for the section of the White River downstream of about WRKM 94. The model-conditioning process resulted in a predicted slope along the lower White River that was much larger than the current condition.

Therefore, the conditioned model for the lower White River is unable to simulate long-term aggradation.

The simulations of changes in bed elevation assume that future climate changes will increase runoff (as described by Elsner and others, 2010) and that the supply of sediment will continue to be large enough for the rivers to transport sediment near capacity. However, with simultaneous projections for increased temperatures (Elsner and others, 2010; Mote and Salathé, 2010) and more intense precipitation (Salathé, 2006), sediment generation and delivery to the rivers may be higher for comparable flows, leading to increased sediment transport and deposition in these river systems. If future sediment transport increases, then future bed-elevation change may be closer to the bed-elevation change from the model-simulation results for the future condition with a 10-percent increase in sediment supply. Additionally, the simulated bed-elevation changes are averaged over a large area, and it is likely that there will be localized variability in bed elevations larger than simulated average changes.

\section{Synthesis of Modeling Bed-Material Transport by Rivers}

One-dimensional river-hydraulic and sediment-transport models were developed using the unified gravel-sand (TUGS) model (Cui, 2007a) for the Nisqually, Carbon, Puyallup, and White Rivers simulating the entrainment, transport, abrasion, and deposition of sediment with channel-geometry, streamflow, and sediment data as major inputs. The upstream extent of each model was chosen where the river had a slope of approximately $0.02 \mathrm{~m} / \mathrm{m}$. A model-conditioning process was used to adjust bed elevations and bed grain-size distributions in order to establish quasi-equilibrium prior to model simulations. Results of model simulations were compared to physical measurements and it was concluded that the models generally were able to simulate predicted loads and were able to provide insight into questions regarding the quantity, spatial and temporal distribution, downstream effect, and future outlook of sediment transport by rivers draining Mount Rainier.

Simulations of the entire long-term streamflow record for the Nisqually River at State Route 7 (NRKM 41.0), Carbon River at State Route 162/Pioneer Way (CRKM 41.0), Puyallup River at Calistoga Street (PRKM 48.6), and White River at R Street (WRKM 104.6) resulted in simulated annual bed-material sediment loads consistent with streamflow that was largest for the Nisqually River $\left(690,000 \mathrm{~m}^{3} / \mathrm{yr}\right)$ and was smaller for the White $\left(530,000 \mathrm{~m}^{3} / \mathrm{yr}\right)$, Puyallup $\left(83,000 \mathrm{~m}^{3} / \mathrm{yr}\right)$, and Carbon $\left(15,000 \mathrm{~m}^{3} / \mathrm{yr}\right)$ Rivers. The simulated bed-material sediment loads were $340,000-1,500,000 \mathrm{~m}^{3} / \mathrm{yr}$ for the Nisqually River, 2,800-77,000 $\mathrm{m}^{3} / \mathrm{yr}$ for the Carbon River, 28,000-260,000 $\mathrm{m}^{3} / \mathrm{yr}$ for the Puyallup River, and 250,000-900,000 $\mathrm{m}^{3} / \mathrm{yr}$ for the White River. The simulated annual bed-material sediment load was, on average, 8, 16, 8, and 16 percent gravel and coarser for the Nisqually, White, Puyallup, and Carbon Rivers, respectively, which suggests that of the sediment measured in the delta of the Nisqually River in Alder Lake, 8 percent is gravel and coarser sediment.

Model simulations investigated how increases in sediment supply to rivers, as pulses distributed during the first year of simulation, are transported through the river systems and affect lowland reaches. The set of model simulations for each river consisted of 36 different conditions: 3 hydrologic conditions, 2 pulse volumes, and 6 pulse grain sizes. The set of model simulations had varied hydrology, repeating 10-year periods of daily discharge of high (WYs 1995-2004), medium (WYs 1975-1984), and low (WYs 1985-1994) flow, pulse volume (100,000 and 500,000 $\mathrm{m}^{3}$ supplied to the upstream end of the model throughout the first simulation year), and pulse grain size (uniform distribution where 100 percent is finer than 4, 8, 16, 32, and $64 \mathrm{~mm}$, and a distribution of sand). For each hydrologic condition, simulation results of a baseline condition (without an input sediment pulse) 
were subtracted from a sediment-pulse condition (with different pulse volumes and grain size) to isolate the response of the input sediment pulse. For each simulation, the input sediment pulse evolved through a combination of translation, dispersion, and attrition as it moved down the river system. The magnitude of geomorphic change at each location along each river due to the input sediment pulse was quantified as the maximum increase through time in bed volume and sediment load compared to the baseline condition.

The characteristic transport time for each simulated pulse to move through the river strongly depended on the grain size of the pulse compared to that of the bed surface. Sediment pulses finer than the median size of the bed surface transported faster than pulses that are closer to the median size of the bed surface, and pulses coarser than the median size of the bed surface transported slowly with in-place attrition dominating pulse evolution (Cui and others, 2003; Cui and Parker, 2005; Sklar and others, 2009). The characteristic transport time for the median sediment size to arrive downstream for the Nisqually River at State Route 7, Carbon River at State Route 162/Pioneer Way, Puyallup River at Calistoga Street, and White River at R Street was approximately 70, 300, 80, and 60 years, respectively. Increased sediment input to the upper rivers beginning in 1967 (Copeland, 2009) would have affected the Puget Lowland sooner in the Puyallup River than in the Carbon River because of their different time scales for downstream transport and change, which may explain the pattern of change in average channel elevation between 1984 and 2009 measured by Czuba and others (2010, fig. 10).

In general, model simulations showed the following: (1) an increase in pulse grain size led to an increase in the characteristic transport time (later time of arrival) and a decrease in sediment load; (2) an increase in pulse volume led to an increase in the characteristic transport time, bed volume, and sediment load; and (3) an increase in streamflow led to a decrease in characteristic transport time and an increase in sediment load. As the pulse grain size gets larger, it takes longer to transport this sediment downstream because fewer flows occur that are capable of transporting this sediment, and when this sediment does arrive, the increased sediment load is smallest for the largest size classes. As the pulse volume increases, it takes longer to transport this sediment downstream because more sediment needs to be moved before half of the pulse is transported, and the bed volume and sediment load increases because there is more sediment that can ultimately deposit and transport as the sediment moves downstream. As the magnitude or frequency of sediment-transporting streamflow increases, sediment moves downstream more rapidly and the loads are larger. The greatest changes in bed volume due to the pulse inputs were closest to the input location, and generally decreased downstream.

Potential changes in hydrologic conditions during the next 25-50 years (Elsner and others, 2010) were simulated to assess possible future effects on bed elevations. The projected future hydrologic conditions were assumed to include a rate of sediment delivery close to the sediment-transport capacity of the upstream end of each river, without excessive aggradation or incision at the upstream end of the model. It is uncertain how the supply of sediment will change with changing streamflow, increased temperatures, and increased storm intensity. Therefore, a sensitivity analysis of the change in potential bed elevation due to the altered streamflow was included that takes into account a 10-percent increase and decrease in sediment supply. The maximum predicted bed-elevation changes for each river (within the modeling domain) after 50 years were about $0.5 \mathrm{~m}$ for the Nisqually River, $0.1 \mathrm{~m}$ for the Carbon River, $0.4 \mathrm{~m}$ for the Puyallup River, and $1.0 \mathrm{~m}$ for the White River assuming these rivers are currently in a quasi-equilibrium state, which may not be the case for select reaches of these rivers. The modelconditioned slope of the White River was larger than the raw input between WRKM 111.0-116.6 because the tendency of the model, during the model-conditioning process, was to increase the slope of the river in order to more efficiently transport sediment through this reach. This highlights that the lower White River (WRKM 111.0-116.6) does not effectively transport sediment downstream and that model 
simulations of potential future bed-elevation change probably are low for this reach. The simulations of changes in bed elevation assume that future climate changes will simply increase the runoff (as described by Elsner and others, 2010) and that the supply of sediment will continue to be large enough for the rivers to transport near capacity. However, with simultaneous projections of increased temperatures (Elsner and others, 2010; Mote and Salathé, 2010) and more intense precipitation (Salathé, 2006), sediment generation and delivery to the rivers may be higher for the same flow leading to increased sediment input and deposition in these river systems.

\section{Implications for River Management}

Although the data are insufficient to state with statistical significance that there is a long-term increasing trend of sediment production from Mount Rainier, predictions of increasing hydrologic runoff with climate change suggest that aggradation rates in the 21 st century may increase. More relevant to river managers working in the catchment, however, is the fact that large sediment loads have affected the region's rivers since at least the early 20th century (Roberts, 1920) and will continue to affect rivers downstream of Mount Rainier as long as an active stratovolcano is located within the watershed and sediment-transporting floods occur.

River managers challenged with balancing objectives of flood protection and ecological productivity are forced to manage sediment generated from an effectively continuous source. Sediment is transported from Mount Rainier to the Puget Lowland through a sequence of glacial and fluvial processes working synchronously to deliver material downstream. Once sediment arrives and deposits in the Puget Lowland, there are limited structural methods for managing sediment to reduce flood risk. Potential sediment-management actions, including setback levees and gravel removal, would be most effective in reaches that tend to accumulate sediment naturally; these reaches were identified based on geomorphic conditions. Furthermore, river management is complicated given future predictions of more intense precipitation in western Washington during the 21st century (Salathé, 2006; Mote and Salathé, 2010) with the potential for more hydrogeomorphic disturbance to mountainous catchments and larger floods that likely will lead to increased sediment production and delivery from Mount Rainier.

\section{Aggradation Potential in the River Network}

The White River has a slope of approximately $0.0060 \mathrm{~m} / \mathrm{m}$ as it exits the mountain front (WRKM 103.0) that decreases to approximately $0.0009 \mathrm{~m} / \mathrm{m}$ before joining the Puyallup River (WRKM 116.6). The sediment-transport model-conditioning process predicted quasi-equilibrium conditions for the lower White River, whereby a minimum slope of $0.0023 \mathrm{~m} / \mathrm{m}$ would be needed to efficiently transport all bedload through the reach. This suggests that the lower White River will continue to aggrade until it reaches a slope of approximately $0.0023 \mathrm{~m} / \mathrm{m}$. In order for the lower White River to achieve this slope, bed elevations would have to increase by more than $8 \mathrm{~m}$ between R Street (WRKM 104.6) and the Lake Tapps Return (WRKM 110.6) (fig. 50). With the current levee-width spacing, the volume of sediment required for the river to reach this quasi-equilibrium state is $4,600,000 \mathrm{~m}^{3}$. If bedload deposited in the White River at the same rate measured between 1984 and $2009\left(16,700 \mathrm{~m}^{3} / \mathrm{y}\right.$; Czuba and others, 2010), this reach of the White River would grade to these equilibrium conditions in about 275 years, assuming deposition patterns of incoming bedload remains constant. This assumption is unrealistic because as slope increases, the reach would more efficiently pass bedload. Nonetheless, this simple analytical exercise illustrates the challenges in managing this reach of the White River.

Analysis of the sediment-transport models and the bedload-transport relation (figs. 27 and 28) indicates that the Carbon River delivers about an order of magnitude less bedload to the Puget Lowland 
than the White River. The bedload transport of the lower Carbon River is small for two reasons: (1) the contributing catchment area is small relative to other main-stem rivers, and (2) the upper Carbon River flows through a wide flood-plain valley still adjusting to the geomorphic influence of Pleistocene alpine glaciation (Church and Slaymaker, 1989). The upper Carbon River has not been subject to multiple, large lahars and associated elevated fluvial sediment loads like the other river systems around Mount Rainier (Scott and others, 1995). As a result, the upper Carbon River likely is retaining a larger proportion of sediment than the neighboring rivers, reflected in the long characteristic residence time of sediment (fig. 43). This reduced bedload potential of the Carbon River also helps explain the findings of Czuba and others (2010) that little to no aggradation occurred in the lower Carbon River near Orting between 1984 and 2009.

The Puyallup River delivers about four times less bedload than the White River. The Puyallup River was affected by multiple large lahars, including the recent Electron Mudflow, that constricted the upper Puyallup River into a more confined flood-plain corridor. The active-channel width analysis (fig. 13) indicates that recent post-1990 sediment delivery to the upper Puyallup River system has been less than sediment delivered to other main-stem rivers.

Given the bedload-transport capacity and new sediment supply from Mount Rainier, the White River near Auburn likely will continue to aggrade significantly in the coming decades. The Puyallup River will experience less severe aggradation, and the Carbon River will experience the least aggradation. Although the Puyallup River near Orting aggraded significantly between 1984 and 2009 (Czuba and others, 2010), this aggradation likely reflected the presence of two setback levee projects, which trapped a larger proportion of the total sediment load.

The upper Nisqually River has a geomorphic character similar to that of the upper White River. The river has been subjected to large fluvial sediment loads during the 20th century, but because it has graded to an equilibrium state influenced by heavy sediment loads during multiple eruptive periods, the reach transports much of the available bedload. The sediment-transport model suggests there is some potential for aggradation along the upper Nisqually River downstream of the national park boundary if large sediment pulses arrive from Mount Rainier.

\section{Potential Sediment-Management Locations}

The methods used for managing sediment to reduce flood risk in the lower Puyallup, White, and Carbon Rivers have changed through time (Pierce County, 2012). From the 1900s through 1960s, major modifications were made to the river channels to increase flow conveyance, including straightening of channels, levee and revetment construction, and removal of sediment and large wood. During the early and middle 20th century, gravel dredging was common, and hundreds of thousands of cubic meters of sediment were removed (Prych, 1988; Czuba and others, 2010; Herrera Environmental Consultants, 2010). With improved awareness of the ecological effects of gravel removal, gravel scalping became the preferred sediment-removal approach. More recently, setback-levee projects have been used to reduce flooding risk (Czuba and others, 2010; Pierce County, 2012).

Potential sediment-management actions, including setback levees and gravel removal, would be more effective in reaches that tend to accumulate sediment naturally. These reaches have less capacity to transport sediment with decreasing channel slope or increasing active-channel width. Additionally, reaches with long characteristic sediment residence times offer a longer window of opportunity to manage the accumulated sediment. Based on the residence time of sediment, locations along each river were roughly characterized into four transport categories: sediment sinks, long-term transient-storage reaches, mid-term transient-storage reaches, and transport reaches. Sediment sinks are areas that significantly aggrade or store sediment over long periods of time (greater than 100 years). Long-term 
transient-storage reaches have long residence times for sediment (between 50 and 100 years) and midterm transient storage reaches have moderate residence times for sediment (between 5-50 years).

Transport reaches transport sediment downstream relatively quickly with short resident times (less than 5 years) and bed-elevation changes in these reaches tend to be small.

Sediment sinks include the Nisqually River delta in Alder Lake and the Puyallup River delta in Commencement Bay of Puget Sound. Long-term transient-storage reaches include the Mud Mountain Dam reservoir (WRKM 63.7-71.0), setback-levee reaches (specifically, PRKM 41.9-44.1 and PRKM 45.6-47.4), the county-line reach of the White River (WRKM 104.5-110.8), and the upper alluvial reach of the Carbon River (CRKM 13.7-24.6) (fig. 51). Mid-term transient-storage reaches include the upper and lower alluvial reaches of the Nisqually River (NRKM 23.0-28.4 and NRKM 32.8-37.2, respectively), the lower alluvial reach of the Carbon River (CRKM 34.4-45.8), the upper and middle alluvial reaches of the Puyallup River (PRKM 16.0-21.3 and PRKM 34.0-49.7 downstream of the bedrock canyon, respectively, and not including setback-levee reaches), and the middle alluvial reach upstream of Mud Mountain Dam on the White River (WRKM 54.3-62.4) (fig. 51). Transport reaches make up the remainder of the river network.

\section{Opportunities for Future Research}

Rivers draining Mount Rainier can be assumed to be in a general state of sediment surplus, a reasonable assumption given recent aggradation trends in Mount Rainier National Park (Beason and Kennard, 2007), aggradation rates measured in the Puget Lowland (Czuba and others, 2010), and the widespread distribution of sand throughout the fluvial network. As a result, future aggradation rates will be largely governed by the underlying hydrology that transports sediment downstream. If a series of large floods occurs in the coming decades, increased rates of aggradation are likely. The rivers in the network transport sediment in quantities proportional to the underlying hydrologic conditions, and the sediment load can vary by an order of magnitude from year to year (Nelson, 1978). River managers tasked with flood management in lowland reaches could monitor the size and duration of peak flows during a winter flood season to get an early indication of aggradation potential. A more direct method of monitoring aggradation includes analyzing flood-conveyance capacity at existing gages (Czuba and others, 2010) or establishing an array of stage gages along an aggrading reach to compare trends in water-surface elevation for a given discharge.

Cross-section analysis (Prych, 1988; Czuba and others, 2010) is an effective way to measure aggradation. Long-term monitoring of georeferenced cross sections in aggradation- and flood-prone reaches of the region's rivers would provide early warning of reduced flood-conveyance capacity. Within the framework of ongoing monitoring, the White River near Auburn is the reach most prone to aggradation and compromised channel-conveyance capacity, thus requiring more frequent monitoring. The Puyallup River near Orting has been subject to significant aggradation recently, but setback levees and a smaller relative sediment supply from upstream means that this reach would require less-frequent monitoring than the lower White River. The upper Nisqually River, upstream of the Nisqually River near National gage, is prone to aggradation, and monitoring cross sections here would provide useful geomorphic data. Although the Carbon River near Orting seems to be a transport reach with less aggradation (Czuba and others, 2010), cross-section monitoring in the lower Carbon River could provide early warning of geomorphic change due to increased bedload arriving from upstream sources. Finally, cross sections established along the White River downstream of the national park boundary could be used to monitor the movement of sediment pulses moving away from Mount Rainier.

Recent advances in sediment-surrogate technologies (Gray and Gartner, 2009; Gray and others, 2010) coupled with strategic sediment sampling enables the near-continuous measurement and reporting 
of sediment load in rivers. The estimated suspended-sediment load for the Puyallup River at Puyallup gage (12101500) and at locations within the watershed may be inaccurate due to the sparse and aging data sets and the variable nature of sediment transport. Recent application of this technology has greatly improved the ability to quantify and reduce uncertainty of sediment-delivery estimates by the Skagit River (Czuba and others, 2011). Application of these technologies would improve the understanding of sediment transport and delivery from rivers draining Mount Rainier. Strategic deployment of sedimentsurrogate technologies (such as turbidity) at key locations within the watershed would improve the monitoring and assessment of geomorphic disturbance (such as landslides and debris flows) as major contributors of sediment to the river system. Measured high turbidity events could be combined with field reconnaissance, aerial photography, and geographic information systems to accurately map sources of sediment and quantify the amount of sediment delivered to the river system (Sobieszczyk and others, 2007).

As the lower White River downstream of R Street continues to aggrade (Czuba and others, 2010), quantifying the amount of sediment transporting past $R$ Street becomes important. Application of passive hydrophones as a bedload surrogate technology (Gray and others, 2010) would provide a near continuous estimate of bedload transport that can be used to anticipate the volume of sediment deposited in the lower White River and subsequent aggradation. Combining the continuous monitoring of bedload past R Street with a stage-monitoring network in the downstream aggrading reach would not only provide timely insight into potentially hazardous accumulation of sediment but also would provide important insight of the hydrological mechanics of sediment delivery from upstream and deposition patterns within the river.

A key component to understanding sediment transport in the White River is a better understanding of the movement of bedload through Mud Mountain Dam. Analysis of topography in the reservoir delta and modeling of the sediment-transport capacity through the structure would give important insight into the current bedload trap efficiency of the dam and how bedload transport rates downstream of the dam may change in the future. Ongoing monitoring of sediment accumulation and delivery downstream also would provide early warning of sediment pulses moving downstream. Because of the unique operations of the dam, the structure also may be a location where gravel could be removed in an ecologically sensitive fashion.

The sediment-production-potential analysis of this study offers a coarse estimate of the sediment generation from mountainous watersheds outside Mount Rainier National Park, but the accuracy of the analysis was limited. The construction of a full sediment budget would help to better identify watersheds prone to sediment production. Estimates of sediment production from landslides would benefit from landslide mapping and assessments of landslide potential from established models (Dietrich and others, 1995; Montgomery and others, 1998). Additionally, new sediment-fingerprinting techniques that identify sources of sediment within sediment budgets (Collins and others, 2010; Evrard and others, 2011; Gellis and Walling, 2011) may be effective at identifying source area from sediment loads in rivers or from sediment accumulations in reservoirs.

\section{Summary and Conclusions}

A comprehensive study of the geomorphology of rivers draining Mount Rainier was completed using published climate-change scenarios to assess current sediment loads, identify sources of sediment to the river network, identify important processes in the sediment-delivery system, evaluate if there were trends in streamflow or sediment load since the early the 20th century, and assess how rates of sedimentation might continue into the future. 
The longitudinal profiles of the Nisqually, Puyallup, Carbon, and White Rivers reflect similar geomorphic evolution since the end of the Pleistocene. Each of these rivers drains Mount Rainier first through alluvial mountainous reaches, and then through one or more bedrock-controlled reaches, and finally through reaches incised into glacial till deposited by the Puget Lobe of the Cordilleran Ice Sheet before entering wide, alluvial flood plains of the Puget Lowland. The rivers were shaped by heavy sediment loads from the volcano. Because of ample sediment supply during the Holocene, the Nisqually, Puyallup, and White Rivers have all graded to a quasi-equilibrium balancing their dominant sediment loads with the underlying hydrology. Although there are aggradation zones of transient accumulation along each river, most of these river corridors efficiently transport sediment from the mountain to deposition zones on alluvial fans in the Puget Lowland. However, geologic evidence along the upper Carbon River suggests this drainage was rarely affected by large lahars. As a result, the active flood plain in the upper Carbon River is unusually wide and the river slope is less than at comparable locations on other rivers. It appears that the Carbon River is still in disequilibrium following Pleistocene alpine glaciation and stores more sediment than it passes. The Muddy Fork Cowlitz River and the Ohanapecosh Rivers mostly cut through long bedrock-controlled reaches for about 10 kilometers before joining in the main-stem Cowlitz River near Packwood. Qualitative assessments of the geomorphology of the Cowlitz River indicate that large recent floods have impacted the Cowlitz River basin, but the overall sediment load likely is less than loads in the other four main-stem rivers draining Mount Rainier.

The total sediment load of the upper Nisqually River from 1945 to 2011 was determined to be $1,200,000 \pm 180,000$ tonnes per year (tonnes/yr), and the total sediment load passing Alder Dam during the same time period was calculated to be $120,000 \pm 18,000$ tonnes/yr. From 1956 to 1985, the total sediment load in the upper Nisqually River was determined to be $860,000 \pm 370,000$ tonnes/yr, a significant decrease relative to the total load from 1945 to 2011 and indicative of a less-active hydrogeomorphic period affecting Mount Rainier from the 1960s to 1980s. Using available suspendedsediment measurements, the suspended-sediment load in the lower Puyallup River at Puyallup was found to be $860,000 \pm 300,000$ tonnes/yr between 1978 and 1994. It is likely that increased streamflow and sediment released from the catchment starting in the 1990s increased the sediment load of the Puyallup River to about 1.0 million tonnes/yr. The White River likely carries a long-term sediment load of about 500,000 tonnes/yr. Calculations from this study showed that the White River at R Street carried a total load of 590,000 tonnes in water year 2011 and an annualized total load of 420,000 tonnes/yr from April 2010 to March 2012.

Bedload was measured to be 64,500 tonnes during water year 2011 along the lower White River and averaged 46,000 tonnes/yr on the White River from April 2010 to March 2012. Bedload versus discharge values were found to be similar on the Carbon, Puyallup, and White Rivers where these rivers exit the mountain front and first enter the Puget Lowland. Using a coarse-resolution bedload-transport relation developed from data for all three rivers and applying to measured daily discharge data from each river, the long-term average bedload from 1984 to 2009 was estimated to be $29,000 \pm 18,000$

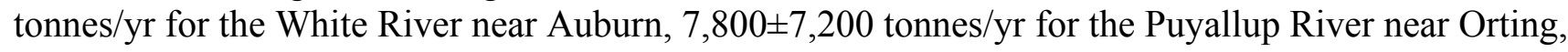
and 2,700 $\pm 2,800$ tonnes/yr for the Carbon River near Orting.

An analysis of 27 mountainous subcatchments contributing to the Nisqually, Puyallup, Carbon, and White Rivers outside Mount Rainier National Park was made to estimate sediment-production potential due to roads, landslides, and soil-creep processes. The upper White River contributed the greatest load of sediment $(130,000 \pm 89,000$ tonnes/yr) while subcatchments to the Nisqually, Puyallup, and Carbon Rivers delivered 50,000 $\pm 33,000$ tonnes/yr, 42,000 $\pm 29,000$ tonnes/yr, and 42,000 $\pm 28,000$ tonnes/yr, respectively. The dominant source of sediment loads was Mount Rainier. For the sediment load in the upper Nisqually River, about 83-98 percent was estimated to originate from within Mount 
Rainier National Park. For the upper White River, about 51-91 percent of the total sediment load was estimated to originate from within the national park. For the lower Puyallup River, with contributions from the White, Carbon, and upper Puyallup River, about 58-93 percent of the total sediment load was estimated to originate from within the national park.

The active-channel width of rivers directly draining Mount Rainier in 2009, used as a proxy for bedload and sediment released from Mount Rainier, was locally as wide as $365 \mathrm{~m}$. The Nisqually River, from the national park boundary to Alder Lake, had the largest average active-channel width in 2009 $(231 \mathrm{~m})$ and the Carbon River upstream of the national park boundary had the next widest reach $(208$ m). In general, active-channel widths of glacier-draining rivers were less in 1965 and 1994 than widths measured in 2009. For most rivers, active-channel width changed little between 1965 and 1994 reflecting a climatic period that was relatively quiet hydrogeomorphically. From 1994 to 2009, a marked increase in hydrogeomorphic disturbance within the watershed caused the active channels in many river reaches to widen. Widening was particularly pronounced in the upper Nisqually River system, the upper Carbon River, the White River, the West Fork White River, and the Mowich River. Little or no disturbance was recorded in the Muddy Fork Cowlitz River, its tributaries, and the Ohanapecosh River. The South Fork Puyallup River also had little change. Comparison of the elevation of the active channel to the first forested terrace adjacent the river showed areas of recent aggradation along much of the Carbon River, along the upper Nisqually River, and along the White River.

Comparing active-channel widths of glacier-draining rivers in 2009 to the distance of glacier retreat between 1913 and 1994 showed no correlation, suggesting that geomorphic disturbance in river reaches directly downstream of glaciers is not strongly governed by the degree of glacial retreat. In contrast, a correlation was found between active-channel width as measured in 2009 and the percentage of superglacier debris mantling the upstream glacier as measured in 1971. A conceptual model of sediment-delivery processes from the mountain suggests that rockfalls, glaciers, debris flows, and mainstem flooding sequentially act to deliver sediment from Mount Rainier to river reaches in the Puget Lowland over decadal time scales. If one or more of these processes slow or cease, the overall sediment delivery to lowland reaches would eventually decrease. Conversely, if all of these processes increased concurrently, sediment delivery to lowland reaches would increase.

Streamflow trends in rivers draining Mount Rainier were linked to the Pacific Decadal Oscillation, which has phases that persist for 20-30 years. Greater-than-normal runoff was associated with cool phases of the Pacific Decadal Oscillation. However, a link between the Pacific Decadal Oscillation and individual peak-flow events was not found. Moreover, streamflow-gaging data from four unregulated rivers directly draining Mount Rainier (the upper Nisqually, Cowlitz, Puyallup, and Carbon Rivers) indicated no statistically significant trends of increasing peak flows over the course of the 20th century.

Data sets collected since the 1940s - that is, sediment accumulation in Alder Lake, analysis of changes in active-channel width, sediment-load data collected from the 1970s to the present, and hydrologic data from gaging stations - indicate that sediment loads from 1990 to the present likely are greater than sediment loads in comparable river reaches from the 1960s to 1980s. Data are insufficient, however, to determine definitively if post-1990 increases in sediment production and transport from Mount Rainier represent a statistically significant increase relative to sediment-load values typical from Mount Rainier during the entire 20th century.

One-dimensional river-hydraulic and sediment-transport models for the Nisqually, Carbon, Puyallup, and White Rivers simulated the entrainment, transport, abrasion, and deposition of sediment with channel-geometry, streamflow, and sediment data as major inputs. Results of model simulations were compared to physical measurements indicating the models generally were able to simulate 
predicted loads and provide insight into aggradation potential along rivers draining Mount Rainier. But coarse data sets and issues arising from uncertainties associated with the downstream boundary condition of some rivers, particularly the White River, created inaccuracies in some predictions of aggradation. Nonetheless, the model proved useful for comparisons between rivers.

Simulations showed that bed-material loads were largest for the Nisqually $(690,000$ cubic meters per year $\left.\left[\mathrm{m}^{3} / \mathrm{yr}\right]\right)$ and White Rivers $\left(530,000 \mathrm{~m}^{3} / \mathrm{yr}\right)$ and smallest for the Puyallup $\left(83,000 \mathrm{~m}^{3} / \mathrm{yr}\right)$ and Carbon Rivers $\left(15,000 \mathrm{~m}^{3} / \mathrm{yr}\right)$ Rivers. The characteristic transport time for each simulated pulse to move through the river strongly depended on the grain size of the pulse compared to that of the bed surface. Sediment pulses finer than the median size of the bed surface transport faster than pulses that are closer to the median size of the bed surface, and pulses coarser than the median size of the bed surface transport slowly with in-place attrition dominating pulse evolution. The characteristic transport times for the median sediment size to arrive downstream for the Nisqually, Carbon, Puyallup, and White Rivers were approximately 70, 300, 80, and 60 years, respectively. In general, model simulations showed that an increase in pulse grain size led to an increase in the characteristic transport time (longer time of arrival) and a decrease in sediment load. An increase in pulse volume led to an increase in the characteristic transport time, bed volume, and sediment load. An increase in streamflow led to a decrease in characteristic transport time and an increase in sediment load. The greatest changes in bed volume due to the pulse inputs were closest to the input location, and generally decreased in the downstream direction.

Potential changes in hydrologic conditions during the next 25 to 50 years were assessed to predict future effects on aggradation. When compared to the current bedload-transport relation for the White River, predicted future changes in hydrologic conditions suggested that bedload transport would increase in the White River by 30 percent in 25 years and by 48 percent in 50 years. Of the river reaches analyzed, the aggradation potential was determined to be the greatest in the lower White River near Auburn, where the slope significantly decreases, incoming sediment load is large, and background hydrology effectively transports bedload through the reach. The lower Puyallup River near Orting also has a large aggradation potential, but the anticipated aggradation here likely will be less than aggradation along the lower White River owing to a smaller contributing catchment and less relative sediment mobilization from Mount Rainier. The Nisqually River, upstream of Alder Lake, has less aggradation potential compared to the lower White River. The lower Carbon River near Orting, owing to its small catchment and small relative sediment-conveyance potential along its upper flood plain, has the smallest potential for future aggradation.

The White River near Auburn has a slope of approximately 0.0060 meters per meter $(\mathrm{m} / \mathrm{m})$ as it exits the mountain front and decreases to approximately $0.0009 \mathrm{~m} / \mathrm{m}$ before it enters the Puyallup River. In order to efficiently transport sediment through this reach, the lower White River will continue to aggrade until it reaches a slope of approximately $0.0023 \mathrm{~m} / \mathrm{m}$, when it will be capable of transporting coarse bedload to the Puyallup River. In order for the lower White River to achieve this slope, bed elevations will have to increase by as much as $8 \mathrm{~m}$. The volume of sediment required for the river to reach this quasi-equilibrium state is $4,600,000 \mathrm{~m}^{3}$, assuming that containment levees are spaced in their current position and are raised with the aggrading bed. Assuming that all bedload past R Street deposits in the White River at a rate of $16,700 \mathrm{~m}^{3} / \mathrm{yr}$, with no gravel removal and no changes in current depositional patterns, the county-line reach of the White River would grade to equilibrium conditions in about 275 years.

Rivers draining Mount Rainier can be assumed to be in a general state of sediment surplus. As a result, future aggradation rates will be largely influenced by the underlying hydrology carrying sediment downstream. Early indications of increasing aggradation can be inferred through monitoring of the size 
and duration of floods during a given winter season using the existing gaging network. Modeling from the study identified reaches within the river network where sediment residence times were large; rivermanagement actions in these reaches, including setback-levee projects and gravel removal, would be more effective than in transport reaches. Long-term river-management decisions can be improved with the monitoring of suspended-sediment load, bedload, and aggradation in river reaches in the Puget Lowland as well as monitoring of key sediment-delivery processes on the mountain, including glacial dynamics and debris-flow activity.

\section{Acknowledgments}

Sarah Henneford, U.S. Geological Survey, digitized many of the historical surveys and helped collect bed-material sediment data. Matt Marineau and Mark Mastin, U.S. Geological Survey, collected bed-material sediment and channel cross-section data. Art Horowitz, U.S. Geological Survey, offered insight concerning calculation of sediment loads using historical data. Yantao Cui, Stillwater Sciences, provided the source code for the TUGS model. Wes Lauer, Seattle University, provided important feedback on the content of the report. Cascade Water Alliance provided funding for turbidity monitoring on the lower White River. The U.S. Army Corps of Engineers provided funding for sediment sampling on the lower White River.

\section{References Cited}

Abbe, T.B., Beason, S., and Bunn, J., 2007, Geomorphic basis of conceptual design Greenwater River restoration project: Memorandum to Eli Asher, South Puget Sound Salmon Enhancement Group, 39 p.

Abbe, T.B., Goldsmith, J, Mostrenko, I, and Brummer, C., 2005, Flood risk assessment and emergency response measures for State Route 410 near Crystal Mountain Boulevard, MP 57-60: Herrera Environmental Consultants, Memorandum to Jim Park, Washington State Department of Transportation, 14 p., accessed August 23, 2012, at http://www.wsdot.wa.gov/NR/rdonlyres/345682AD-8D8B-4193-ACB7581ADEB2D3B5/0/CED_WhiteRiver_A.pdf.

Abbe, T.B., and Montgomery, D.R., 1996, Large woody debris jams, channel hydraulics, and habitat formation in large rivers: Regulated Rivers-Research and Management, v. 12, no. 2-3, p. 201-221. Allan, R.P., 2011, Climate change-Human influence on rainfall: Nature, v. 470, no. 7334, p. 344-345, doi:10.1038/470344a.

Bagnold, R.A., 1966, An approach to the sediment transport problem from general physics: U.S. Geological Survey Professional Paper 422-I, 37 p. (Also available at http://pubs.er.usgs.gov/publication/pp422I.)

Barcott, B., 1997, The measure of a mountain — Beauty and terror on Mount Rainier: Seattle, Wash., Sasquatch Books, $278 \mathrm{p}$.

Beason, S.R., 2007, The environmental implications of aggradation in major braided rivers at Mount Rainier National Park, Washington: Cedar Falls, University of Northern Iowa, M.S. thesis, 165 p.

Beason, S.R., and Kennard, P.M., 2007, Environmental and ecological implications of aggradation in braided rivers at Mount Rainier National Park: National Park Service, Natural Resource Year in Review-2006, A portrait of the year in natural resource stewardship and science in the National Park System, p. 52-53. 
Benda, L., and Dunne, T., 1997, Stochastic forcing of sediment routing and storage in channel networks: Water Resources Research, v. 33, no. 12, p. 2,865-2,880.

Beverage, J.P., and Culbertson, J.K., 1964, Hyperconcentrations of suspended sediment:Proceedings of the American Society of Civil Engineers, Journal of the Hydraulics Division, v. 90, no. HY6, p. 117128.

Booth, D.B., 1994, Glaciofluvial infilling and scour of the Puget lowlands, Washington, during icesheet glaciation: Geology, v. 22, no. 8, p. 695-698.

Brummer, C.J., Abbe, T.B., Sampson, J.R., and Montgomery, D.R., 2006, Influence of vertical channel change associated with wood accumulations on delineating channel migration zones, Washington, USA: Geomorphology, v. 80, p. 295-309, doi:10.1016/j.geomorph.2006.03.002.

Brummer, C.J., and Montgomery, D.R., 2006, Influence of coarse lag formation on the mechanics of sediment pulse dispersion in a mountain stream, Squire Creek, North Cascades, Washington, United States: Water Resources Research, v. 42, no. W07412, 16 p., doi:10.1029/2005WR004776.

Brune, G.M., 1953, Trap efficiency of reservoirs: Transactions, American Geophysical Union, v. 34, no. 3, p. 407-418.

Burbank, D.W., 1981, A chronology of late Holocene glacier fluctuations on Mount Rainier, Washington: Arctic and Alpine Research v. 13, no. 4, p. 369-386.

Childers, D., Kresch, K.L., Gustafson, S.A., Randle, T.J., Melena, J.T., and Cluer, B., 2000, Hydrologic data collected during the 1994 Lake Mills drawdown experiment, Elwha River, Washington: U.S. Geological Survey Water-Resources Investigations Report 99-4215, 115 p. (Also available at http://pubs.er.usgs.gov/publication/wri994215.)

Chittenden, H.M., 1907, Report of an investigation by a board of engineers of the means of controlling floods in the Duwamish-Puyallup valleys and their tributaries in the State of Washington: Seattle, Wash., Lowman and Hanford S. and P. Co., 32 p.

Church, M., and Ryder, J.M., 1972, Paraglacial sedimentation-A consideration of fluvial processes conditioned by glaciation: Geological Society of America Bulletin, v. 83, no. 10, p. 3,059-3,072.

Church, M., and Slaymaker, O., 1989, Disequilibrium of Holocene sediment yield in glaciated British Columbia: Nature, v. 337, no. 6206, p. 452-454.

Collins, A.L., Walling, D.E., Webb, L., and King, P., 2010, Apportioning catchment scale sediment sources using a modified composite fingerprinting technique incorporating property weightings and prior information: Geoderma, v. 155, no. 3-4, p. 249-261, doi:10.1016/j.geoderma.2009.12.008.

Collins, B.D., and Dunne, T., 1989, Gravel transport, gravel harvesting, and channel-bed degradation in rivers draining the southern Olympic Mountains, Washington, U.S.A.: Environmental Geology, v. 13, no. 3, p. 213-224.

Collins, B.D., and Montgomery, D.R., 2011, The legacy of Pleistocene glaciation and the organization of lowland alluvial process domains in the Puget Sound region: Geomorphology, v. 126, no. 1-2, p. 174-185, doi:10.1016/j.geomorph.2010.11.002.

Collins, B.D., Montgomery, D.R., Fetherston, K.L, and Abbe, T.B., 2012, The floodplain large-wood cycle hypothesis - A mechanism for the physical and biotic structuring of temperate forested alluvial valleys in the North Pacific coastal ecoregion: Geomorphology, v. 139-140, no. 0, p. 460-470, doi:10.1016/j.geomorph.2011.11.011.

Copeland, E.A., 2009, Recent periglacial debris flows from Mount Rainier, Washington: Corvallis, Oregon State University, M.S. thesis, 124 p.

Costa, J.E., 1988, Rheologic, geomorphic, and sedimentologic differentiation of water floods, hyperconcentrate flows, and debris flows, in Baker, V.R., Kochel, R.C., and Patton, P.C., eds., Flood Geomorphology: New York, Wiley, p. 113-122. 
Crandell, D.R., 1963, Surficial geology and geomorphology of the Lake Tapps quadrangle, Washington: U.S. Geological Survey Professional Paper 388-A, 84 p. (Also available at http://pubs.er.usgs.gov/publication/pp388A.)

Crandell, D.R., 1971, Postglacial lahars from Mount Rainier volcano, Washington: U.S. Geological Survey Professional Paper 677, 75 p. (Also available at http://pubs.er.usgs.gov/publication/pp677.)

Crandell, D.R., and R.K. Fahnestock, 1965, Rockfalls and avalanches from Little Tahoma Peak on Mount Rainier, Washington: U.S. Geological Survey Bulletin 1221-A, 30 p. (Also available at http://pubs.er.usgs.gov/publication/b1221A.)

Crandell, D.R., and R.D. Miller, 1974, Quaternary stratigraphy and extent of glaciation in the Mount Rainier Region, Washington: U.S. Geological Survey Professional Paper 847, 59 p. (Also available at http://pubs.er.usgs.gov/publication/pp847.)

Cui, Y., 2007a, The unified gravel-sand (TUGS) model—Simulating sediment transport and gravel-sand grain size distributions in gravel-bedded rivers: Water Resources Research, v. 43, no. W10436, 16 p, doi:10.1029/2006wr005330.

Cui, Y., 2007b, Examining the dynamics of grain size distributions of gravel-sand deposits in the Sandy River, Oregon with a numerical model: River Research and Applications, v. 23, p. 732-751, doi:10.1002/rra.1012.

Cui, Y., and Parker, G., 2005, Numerical model of sediment pulses and sediment-supply disturbances in mountain rivers: Journal of Hydraulic Engineering, v. 131, no. 8, p. 646-656, doi:10.1061/(asce)0733-9429(2005)131:8(646).

Cui, Y., Parker, G., Braudrick, C., Dietrich, W.E., and Cluer, B., 2006a, Dam removal express assessment models (DREAM) part 1-Model development and validation: Journal of Hydraulic Research, v. 44, no. 3, p. 291-307, doi:10.1080/00221686.2006.9521683.

Cui, Y., Parker, G., Braudrick, C., Dietrich, W.E., and Cluer, B., 2006b, Dam removal express assessment models (DREAM) part 2 - Sample runs-sensitivity tests: Journal of Hydraulic Research, v. 44, no. 3, p. 308-323, doi:10.1080/00221686.2006.9521684.

Cui, Y., Parker, G., Pizzuto, J., and Lisle, T.E., 2003, Sediment pulses in mountain rivers-2. comparison between experiments and numerical predictions: Water Resources Research, v. 39, no. 9, 11 p, doi:10.1029/2002WR001805.

Cui, Y., and Wilcox, A., 2008, Development and application of numerical models of sediment transport associated with dam removal, chap. 23 of Garcia, M.H., ed., Sedimentation engineering-Processes, measurements, modeling, and practice: American Society of Civil Engineers manuals and reports on engineering practice no. 110., p. 995-1,020.

Czuba, J.A., Czuba, C.R., Magirl, C.S., and Voss, F.D., 2010, Channel-conveyance capacity, channel change, and sediment transport in the lower Puyallup, White, and Carbon Rivers, western Washington: U.S. Geological Survey Scientific Investigations Report 2010-5240, 104 p. (Also available at http://pubs.er.usgs.gov/publication/sir20105240.)

Czuba, J.A., Magirl, C.S., Czuba, C.R., Grossman, E.E., Curran, C.A., Gendaszek, A.S., and Dinicola, R.S., 2011, Sediment load from major rivers into Puget Sound and its adjacent waters: U.S. Geological Survey Fact Sheet 2011-3083, 4 p. (Also available at http://pubs.er.usgs.gov/publication/fs20113083.)

Czuba, J.A., Olsen, T.D., Czuba, C.R., Magirl, C.S., and Gish, C.C., 2012, Changes in sediment volume in Alder Lake, Nisqually River basin, Washington, 1945-2011: U.S. Geological Survey Open-File Report 2012-1068, 30 p. (Also available at http://pubs.er.usgs.gov/publication/ofr20121068.) 
Davis, B.E., 2005, A guide to the proper selection and use of federally approved sediment and waterquality samplers: U.S. Geological Survey Open-File Report 2005-1087, 26 p. (Also available at http://pubs.er.usgs.gov/publication/ofr20051087.)

Dietrich, W.E., and Dunne T., 1978, Sediment budget for a small catchment in mountainous terrain: Zeitschrift für Geomorphologie N.F, v. 29, p. 191-206.

Dietrich, W.E., Dunne, T., Humphrey, N.F., and Reid, L.M., 1982, Construction of sediment budgets for drainage basins, in Swanson, F.J., Janda, R.J., Dunne, T., and Swanston, D.N., eds., Sediment budgets and routing in forested drainage basins: U.S. Forest Service General Technical Report PNW141, p. 5-23.

Dietrich, W. E., Reiss, R., Hsu, M.-L., and Montgomery, D. R., 1995, A process-based model for colluvial soil depth and shallow landsliding using digital elevation data: Hydrological Processes, v. 9, no. 3-4, p. 383-400.

Downing, J., 1983, The coast of Puget Sound: its processes and development: Seattle, University of Washington Press, $126 \mathrm{p}$.

Dragovich, J.D., Pringle, P.T., and Walsh, T.J., 1994, Extent and geometry of the mid-Holocene Osceola mudflow in the Puget Lowland-Implications for Holocene sedimentation and paleography: Washington Geology, v. 22, no. 3, p. 3-26.

Driedger, C., and Kennard, P.M., 1986, Ice volumes on Cascade volcanoes: Mount Rainier, Mount Hood, Three Sisters, and Mount Shasta: U.S. Geological Survey Professional Paper 1365, 28 p. (Also available at http://pubs.er.usgs.gov/publication/pp1365.)

Driedger, C.L., and Fountain A.G., 1989, Glacier outburst floods at Mount Rainier, Washington State, U.S.A.: Annals of Glaciology, v. 13, p. 51-55.

Duan, N. 1983, Smearing estimate-A nonparametric retransformation method: Journal of the American Statistical Association, v. 78, no. 383, p. 605-610.

Dunne, T., 1986, Sediment transport and sedimentation between RMs 5 and 30 along the White River, Washington: Bellevue, Wash., 39 p.

Dust, D., and Wohl E., 2012, Conceptual model for complex river responses using an expanded Lane's relation: Geomorphology, v. 139-140, p. 109-121, doi:10.1016/j.geomorph.2011.10.008.

Edwards, T.K., and Glysson, D.G., 1999, Field methods for measurement of fluvial sediment: U.S. Geological Survey Techniques of Water-Resources Investigations, book 3, chap. C2, 89 p.

Elsner, M.M., Cuo, L., Voisin, N., Deems, J.S., Hamlet, A.F., Vano, J.A., Mickelson, K.E.B., Lee, S.Y., and Lettenmaier, D.P., 2010, Implications of 21st century climate change for the hydrology of

Washington State: Climate Change, v. 102, p. 225-260, doi:10.1007/s10584-010-9855-0.

Evrard, O., Navratil, O., Ayrault, S. Ahmadi, M., Némery, J., Legout, C., Lefèvre, I., Poirel, A., Bonté, P., and Esteves, M., 2011, Combining suspended sediment monitoring and fingerprinting to determine the spatial origin of fine sediment in a mountainous river catchment: Earth Surface Processes and Landforms, v. 36, no. 8, p. 1,072-1,089, doi:10.1002/esp.2133.

Fahnestock, R.K., 1963. Morphology and hydrology of a glacial stream-White River, Mount Rainier, Washington: U.S. Geological Survey Professional Paper 422-A, 70 p. (Also available at http://pubs.er.usgs.gov/publication/pp422A.)

Ferguson, R.I., 2003, Emergence of abrupt gravel to sand transitions along rivers through sorting processes: Geology, v. 31, no. 2, p. 159-162, doi:10.1130/00917613(2003)031<0159:eoagts $>2.0 . c 0 ; 2$.

Fox, M., and Bolton, S., 2007, A regional and geomorphic reference for quantities and volumes of instream wood in unmanaged forested basins of Washington State: North American Journal of Fisheries Management, v. 27, no. 1, p. 342-359, doi:10.1577/m05-024.1. 
Frank, D.G., 1985, Hydrothermal processes at Mount Rainier: Seattle, University of Washington, Ph.D. thesis, $195 \mathrm{p}$.

Frank, D.G., 1995, Surficial extent and conceptual model of hydrothermal system at Mount Rainier, Washington: Journal of Volcanology and Geothermal Research, v. 65, no. 1-2, p. 51-80.

Gellis, A.C., and Walling, D.E., 2011, Sediment source fingerprinting (tracing) and sediment budgets as tools in targeting river and watershed restoration programs, in Simon, A., Bennett, S.J, and Castro, J.M., eds., Stream restoration in dynamic fluvial systems - Scientific approaches, analyses, and tools: Washington, D.C., American Geophysical Union, Geophysical Monograph Series 194, p. 263-291, doi:10.1029/2010GM000960.

GeoEngineers, 2007, Channel migration- and avulsion-potential analyses, upper Nisqually River, Pierce County, Washington: Report prepared for Pierce County Public Works and Utilities, Water Programs Division, File no. 2998-009-00, June 26, 2007, 19 p.

Gilbert, G.K., and Murphy, E.C., 1914, The transportation of debris by running water: U.S. Geological Survey Professional Paper 86, 263 p. (Also available at http://pubs.er.usgs.gov/publication/pp86.)

Gomez, B., Cui, Y., Kettner, A.J., Peacock, D.H., and Syvitski, J.P.M., 2009, Simulating changes to the sediment transport regime of the Waipaoa River, New Zealand, driven by climate change in the twenty-first century: Global and Planetary Change, v. 67, p. 153-166.

Gray, J.R., and Gartner, J.W., 2009, Technological advances in suspended-sediment surrogate monitoring: Water Resources Research, v. 45, no. W00D29, 20 p, doi:10.1029/2008WR007063.

Gray, J.R., Laronne, J.B., Marr, J.D.G., 2010, Bedload-surrogate monitoring technologies: U.S. Geological Survey Scientific Investigations Report 2010-5091, 37 p. (Also available at http://pubs.er.usgs.gov/publication/sir20105091.)

Griswold, J.P., and Iverson, R.M., 2008, Mobility statistics and automated hazard mapping for debris flows and rock avalanches: U.S. Geological Survey Scientific Investigations Report 2007-5276, 59 p. (Also available at http://pubs.er.usgs.gov/publication/sir20075276.)

Hallet, B., Hunter, L., and Bogen, J., 1996, Rates of erosion and sediment evacuation by glaciers-A review of field data and their implications: Global and Planetary Change, v. 12, no. 1-4, p. 213-235. Harrison, A.E., 1956, Fluctuations of the Nisqually Glacier, Mt. Rainier, Washington, since 1750: Journal of Glaciology, v. 19, p. 675-683.

Heine, J.T., 1998, Extent, timing, and climatic implications of glacier advances Mount Rainier, Washington, U.S.A. at the Pleistocene-Holocene transition: Quaternary Science Reviews, v. 17, no. 12 , p. $1,139-1,148$.

Helsel, D.R., and Hirsch, R.M., 1992, Statistical methods in water resources: New York, Elsevier, 522 p.

Henshaw, F.F., and Parker, G.L., 1913, Water powers of the Cascade Range, part II-Cowlitz, Nisqually, Puyallup, White, Green, and Cedar drainage basins: U.S. Geological Survey Water-Supply Paper 313, 170 p. (Also available at http://pubs.er.usgs.gov/publication/wsp313.)

Herrera Environmental Consultants, 2005, Hydraulic analysis-White River bypass reach RM 3.6 to 24.3:Report prepared for the Puyallup Tribe of Indians, November 30, 2005, Seattle, Wash.

Herrera Environmental Consultants, 2010, Summary of sediment trends, lower White River - RM 4.44 to RM 10.60: Report prepared for King County, February 10, 2010, Seattle, Wash., 66 p.

Hirsch, R.M., and Ryberg, K.R., 2011, Has the magnitude of floods across the USA changed with global $\mathrm{CO}_{2}$ levels?: Hydrological Sciences Journal, p. 1-9, doi:10.1080/02626667.2011.621895. Hoblitt, R.P., Walder, J.S., Driedger, C.L., Scott, K.M., Pringle, P.T., and Vallance, J.W., 1998, Volcano hazards from Mount Rainier, Washington: U.S. Geological Survey Open-File Report 98428, 11 p. (Also available at http://pubs.er.usgs.gov/publication/ofr98428.) 
Hoey, T.B., and Bluck B.J., 1999, Identifying the controls over downstream fining of river gravels: Journal of Sedimentary Research, v. 69, no. 1, p. 40-50.

Horowitz, A.J., 2003, An evaluation of sediment rating curves for estimating suspended sediment concentrations for subsequent flux calculations: Hydrological Processes, v. 17, p. 2,287-3,409, doi:10.1002/hyp.1299.

Horowitz, A.J., 2010, A quarter century of declining suspended sediment fluxes in the Mississippi River and the effect of the 1993 flood: Hydrological Processes, v. 24, p. 13-34, doi:10.1002/hyp.7425.

Iverson, R.M., 2000, Landslide triggering by rain infiltration: Water Resources Research, v. 36, no. 7, p. 1,897-1,910, doi:10.1029/2000wr900090.

Iverson, R.M., Schilling, S.P., and Vallance, J.W., 1998, Objective delineation of lahar-inundation hazard zones: Geological Society of America Bulletin, v. 110, no. 8, p. 972-984.

Kennard, P.M., Abbe, T., Ericsson, M., Bjork, J., and Beason, S., 2011, The role of riparian forests in river avulsion and floodplain disequilibrium in aggrading pro-glacial braided rivers-A newly recognized model in fluvial geomorphology, in Geological Society of America Annual Meeting, Minneapolis, Minn., 2011: Geological Society of America Abstracts with Programs, v. 43, no. 5, p. 164.

Ketcheson, G., Leinenback, P., Schuett-Hames, J., Whiley, T., and James, C., 2003, Mt. BakerSnoqualmie National Forest, Upper White watershed sediment and temperature TMDL for aquatic habitat: Washington State Department of Ecology, publication no. 03-10-032, 107 p.

Knighton, A.D., 1989, River adjustment to changes in sediment load: The effects of tin mining on the Ringarooma River, Tasmania, 1875-1984: Earth Surface Processes and Landforms, v. 14, no. 4, p. 333-359.

Krimmel, R.M., 2002, Glaciers of the conterminous United States-Glaciers of the western United States, in Williams, R.S., Jr., and Feffigno, J.G., eds., Satellite image atlas of glaciers of the Wworld-North America: U.S. Geological Survey Professional Paper 1386-J, p. J329-J381. (Also available at http://pubs.er.usgs.gov/publication/pp1386J.)

Labbe, J.M., Hadley, K.S., Schipper, A.M., Leuven, R.S.E.W., and Gardiner, C.P., 2011, Influence of bank materials, bed sediment, and riparian vegetation on channel form along a gravel-to-sand transition reach of the Upper Tualatin River, Oregon, USA: Geomorphology, v. 125, p. 374-382, doi:10.1016/j.geomorph.2010.10.013.

Lancaster, S.T., Nolin, A.W., Copeland, E.A., and Grant, G.E., 2012, Periglacial debris-flow initiation and susceptibility and glacier recession from imagery, airborne LiDAR, and ground-based mapping: Geosphere, v. 8, no. 2, 14 p., doi:10.1130/GES00713.1.

Lane, E.W., 1955, The importance of fluvial morphology in hydraulic engineering: Proceedings of American Society of Civil Engineers, Journal of the Hydrologic Division, v. 81, no. 745, p. 1-17.

Langbein, W.B., and Leopold, L.B., 1964, Quasi-equilibrium states in channel morphology: American Journal of Science, v. 262, p. 782-794.

Lauer, J.W., and Parker G., 2008, Net local removal of floodplain sediment by river meander migration: Geomorphology, v. 96, no. 1-2, p. 123-149, doi:10.1016/j.geomorph.2007.08.003.

Lauer, J.W., Parker, G., and Dietrich, W.E., 2008, Response of the Strickland and Fly River confluence to postglacial sea level rise: Journal of Geophysical Research, v. 113, no. F01S06, 22 p., doi:10.1029/2006jf000626.

Laurie, G.J., 2002, A natural channel design to restore the Greenwater River-Mt. Baker-Snoqualmie National Forest: U.S. Forest Service, 69 p. 
Leonard, E.M., 1997, The relationship between glacial activity and sediment production:-Evidence from a 4450-year varve record of neoglacial sedimentation in Hector Lake, Alberta, Canada: Journal of Paleolimnology, v. 17, no. 3, p. 319-330.

Leopold, L.B., and Bull, W.B., 1979, Base level, aggradation, and grade: Proceedings of the American Philosophical Society, v. 123, no. 3, p. 168-202.

Leopold, L.B., and Maddock, T.J., 1953, The Hydraulic geometry of stream channels and some physiographic implications: U.S. Geological Survey Professional Paper 252, 57 p. (Also available at http://pubs.er.usgs.gov/publication/pp252.)

Leopold, L., Wolman, M.G., and Miller, J.P., 1964, Fluvial processes in geomorphology: San Francisco, W.H. Freeman and Company, 522 p.

Lisle, T.E., 2008, The evolution of sediment waves influenced by varying transport capacity in heterogeneous rivers, in Habersack, H., Piégay H., and Rinaldi, M., eds., Gravel-bed rivers VI-From process understanding to river restoration: Amsterdam, The Netherlands, Elsevier, p. 443-469, doi: 10.1016/S0928-2025(07)11136-6.

Lyons, J.K., and Beschta, R.L., 1983, Land use, floods, and channel changes-Upper Middle Fork Willamette River, Oregon (1936-1980): Water Resources Research, v. 19, no. 2, p. 463-471.

Madej, M.A., and Ozaki, V., 1996, Channel response to sediment wave propogation and movement, Redwood Creek, California, USA: Earth Surface Processes and Landforms, v. 21, p. 911-927.

Madej, M.A., Sutherland, D.G., Lisle, T.E., and Pryor, B., 2009, Channel responses to varying sediment input-A flume experiment modeled after Redwood Creek, California: Geomorphology, v. 103, no. 4, p. 507-519, doi:10.1016/j.geomorph.2008.07.017.

Maizels, J.K., 1979, Proglacial aggradation and changes in braided channel patterns during a period of glacier advance-An alpine example: Geografiska Annaler, Series A, Physical Geography, v. 61, no. $1-2$, p. 87-101.

Major, J.J, 2004, Posteruption suspended sediment transport at Mount St. Helens: Decadal-scale relationships with landscape adjustments and river discharges: Journal of Geophysical Research v. 109, no. F01002, 22 p., doi: 10.1029/2002JF000010.

Major, J.J., Pierson, T.C., Dinehart, R.L., and Costa, J.E., 2000, Sediment yield following severe volcanic disturbance-A two-decade perspective from Mount St. Helens: Geology, v. 28, no. 9, p. 819-822.

Mantua, N.J., Hare, S.R., Zhang, Y., Wallace, J.M., and Francis, R.C., 1997, A Pacific interdecadal climate oscillation with impacts on salmon production: Bulletin of the American Meteorological Society, v. 78, no. 6, p. 1,069-1,079.

Mass, C., Skalenakis, A., and Warner, M., 2011, Extreme precipitation over the West Coast of North America-Is there a trend?: Journal of Hydrometeorology, v. 12, no. 2, p. 310-318, doi:10.1175/2010JHM1341.1.

Mastin, M.C., Gendaszek, A.S., and Barnas, C.R., 2010, Magnitude and extent of flooding at selected riverreaches in Western Washington, January 2009: U.S. Geological Survey Scientific Investigations Report 2010-5177, 34 p. (Also available at http://pubs.er.usgs.gov/publication/sir20105177.)

McCabe, G.J., and M.D. Dettinger, 1999, Decadal variations in the strength of ENSO teleconnections with precipitation in the western United States: International Journal of Climatology, v. 19, no. 13, p. 1,399-1,410, doi:10.1002/(sici)1097-0088(19991115)19:13<1399::aid-joc457>3.0.co;2-a.

McCabe, G.J. and M.D. Dettinger, 2002, Primary modes and predictability of year-to-year snowpack variations in the western United States from teleconnections with Pacific Ocean climate: Journal of Hydrometeorology, v. 3, no. 1, p. 13-25, doi:10.1175/1525-7541(2002)003<0013:pmapoy>2.0.co;2. 
Metcalf, R.C., 1979, Energy dissipation during subglacial abrasion at Nisqually Glacier, Washington, U.S.A.: Journal of Glaciology v. 23, no. 89, p. 233-246.

Miller, D.J., and Benda, L.E., 2000, Effects of punctuated sediment supply on valley-floor landforms and sediment transport, Geological Society of America Bulletin, v. 112, no. 12, p. 1,814-1,824, doi:10.1130/0016-7606(2000)112<1814:eopsso>2.0.co;2.

Milliman, J.D., and Farnsworth, K.L., 2011, River discharge to the coastal ocean-A global synthesis: New York, Cambridge University Press, 392 p.

Mills, H.H., 1976, Estimated erosion rates on Mount Rainier, Washington: Geology, v. 4, no. 7, p. 401406.

Mills, H.H., 1979, Some implications of sediment studies for glacial erosion on Mount Rainier, Washington: Northwest Science, v. 53 no. 3, p. 190-199.

Min, S.K., Zhang, X., Zwiers, F.W., and Hegerl, G.C., 2011, Human contribution to more-intense precipitation extremes: Nature, v. 470, no. 7334, p. 378-381, doi:10.1038/nature09763.

Montgomery, D.R., and Buffington, J.M., 1997, Channel-reach morphology in mountain drainage basins: Geological Society of America Bulletin, v. 109, no. 5, p. 596-611, doi:10.1130/00167606(1997)109<0596:CRMIMD>2.3.CO;2.

Montgomery, D.R., and Dietrich, W.E., 1994, A physically based model for the topographic control on shallow landsliding: Water Resources Research, v. 30, no. 4, p. 1,153-1,171, doi:10.1029/93WR02979.

Montgomery, D.R., Dietrich, W.E., and Heffner, J.T., 2002, Piezometric response in shallow bedrock at CB1-Implications for runoff generation and landsliding: Water Resources Research, v. 38, no. 12:1274, 18 p., doi:10.1029/2002WR001429.

Montgomery, D.R., Sullivan, K., and Greenberg, H.M., 1998, Regional test of a model for shallow landsliding: Hydrological Processes, v. 12, no. 6, p. 943-955.

Mote, P.W., and Salathé, E.P., 2010, Future climate in the Pacific Northwest: Climatic Change, v. 102, no. 1-2, p. 29-50, doi:10.1007/s10584-010-9848-z.

National Oceanic and Atmospheric Administration, 2010a, ESA salmon listings: National Oceanic and Atmospheric Administration Northwest Regional Office web site, accessed August 24, 2012, at http://www.nwr.noaa.gov/ESA-Salmon-Listings/.

National Oceanic and Atmospheric Administration, 2010b, Climate of Washington: National Oceanic and Atmospheric Administration Western Regional Climate Center web site, accessed August 24, 2012, at http://www.wrcc.dri.edu/narratives/WASHINGTON.htm.

National Oceanic and Atmospheric Administration, 2012, National Weather Service Glossary, accessed August 24, 2012, at http://www.crh.noaa.gov/glossary.php.

National Resources Conservation Service, 2011, SNOTEL site Paradise, Washington, United States Department of Agriculture, accessed August 30, 2012, at http://www.wcc.nrcs.usda.gov/nwcc/site? sitenum $=679 \&$ state $=w a$.

Neiman, P.J., Schick, L.J., Ralph, F.M., Hughes, M., and Wick, G.A., 2011, Flooding in western Washington-The connection to atmospheric rivers: Journal of Hydrometeorology v. 12, p. 1,3371,358, doi:10.1175/2011JHM1358.1.

Nelson, E.J., and Booth, D.B., 2002, Sediment sources in an urbanizing, mixed land-use watershed: Journal of Hydrology, v. 264, no. 1-4, p. 51-68, doi:10.1016/s0022-1694(02)00059-8.

Nelson, L.M., 1971, Sediment transport by streams in the Snohomish River Basin, Washington, October 1967-June 1969: U.S. Geological Survey Open-File Report 71-215, 44 p. (Also available at http://pubs.er.usgs.gov/publication/ofr71215.) 
Nelson, L.M., 1974, Sediment transport by streams in the Deschutes and Nisqually River basins, Washington, November 1971-June 1973: U.S. Geological Survey Open-File Report 74--1078, 33 p. (Also available at http://pubs.er.usgs.gov/publication/ofr741078.)

Nelson, L.M., 1978, Sediment transport by the White River into Mud Mountain Reservoir, Washington, June 1974-June 1976: U.S. Geological Survey Water-Resources Investigations 78-133, 26 p. (Also available at http://pubs.er.usgs.gov/publication/wri78133.)

Newman, M., Compo, G.P., and Alexander, M.A., 2003, ENSO-forces variability of the Pacific Decadal Oscillation: Journal of Climate, v. 16, no. 23, p. 3,853-3,857.

Nylen, T.H., 2004, Spatial and temporal variations of glaciers (1913-1994) on Mt. Rainier and the relation with climate: Portland, Oreg., Portland State University, master's thesis, $114 \mathrm{p}$.

O'Connor, J.E., and Costa J.E., 1993, Geologic and hydrologic hazards in glacerized basins in North America resulting from 19th and 20th century global warming: Natural Hazards, v. 8, p. 121-140. O'Connor, J.E., Jones, M.A., and Haluska, T.L., 2003, Flood plain and channel dynamics of the Quinault and Queets Rivers, Washington, USA: Geomorphology, v. 51, no. 1-3, p. 31-59, doi:10.1016/S0169-555X(02)00324-0.

O'Connor, J.E., Sarna-Wojcicki, A.M., Wozniak, K.C., Polette, D.J., and Fleck, R.J., 2001, Origin, extent, and thickness of Quaternary geologic units in the Willamette Valley, Oregon: U.S. Geological Survey Professional Paper 1620, 52 p. (Also available at http://pubs.er.usgs.gov/publication/pp1620.)

Parker, G., 1991a, Selective sorting and abrasion of river gravel, I-Theory: Journal of Hydraulic Engineering, v. 117, no. 2, p. 131-149.

Parker, G., 1991b, Selective sorting and abrasion of river gravel, II-Applications: Journal of Hydraulic Enginerring, v. 117, no. 2, p. 150-171.

Parker, G., Wilcock, P.R., Paola, C., Dietrich, W.E., and Pitlick, J., 2007, Physical basis for quasiuniversal relations describing bankfull hydraulic geometry of single-thread gravel bed rivers: Journal of Geophysical Research, v. 112, no. F04005, 21 p., doi:10.1029/2006JF000549.

Pelto, M.S., 2006, The current disequilibrium of North Cascade glaciers: Hydrological Processes, v. 20, no. 4, p. 769-779, doi:10.1002/hyp.6132.

Pelto, M.S., and Riedel, J., 2001, Spatial and temporal variations in annual balance of North Cascade glaciers, Washington 1984-2000: Hydrological Processes, v. 15, no. 18, p. 3,461-3,472, doi:10.1002/hyp.1042.

Pierce County, 2012, Rivers flood hazard management plan-executive proposal: accessed September 12,2012 , at http://www.co.pierce.wa.us/pc/services/home/environ/water/wqws/floodhazmgmtplan8.htm.

Pierson, T.C., 2005, Hyperconcentrated flow-Transitional process between water flow and debris flow, in Jakob, M., and Hungr, O., eds., Debris-flow hazards and related phenomena: New York, Springer-Verlag, p. 159-202.

Pierson, T.C., and Costa, J.E., 1987, A rheologic classification of subaerial sediment-water flows, in Costa, J.E., and Wieczorek, G.F., eds., Reviews in engineering geology, volume VII, Debris flowsavalanches-Process, recognition, and mitigation: Boulder, Colo., Geological Society of America, p. $1-12$.

Pierson, T.C., Pringle, P.T., and Cameron, K.A., 2011, Magnitude and timing of downstream channel aggradation and degradation in response to a dome-building eruption at Mount Hood, Oregon: Geological Society of America Bulletin, v. 123, no. 1-2, p. 3-20, doi:10.1130/b30127.1.

Pierson, T.C., and Scott, K.M., 1985, Downstream dilution of a lahar-Transition from debris flow to hyperconcentrated streamflow: Water Resources Research, v. 21, no. 10, p. 1,511-1,524. 
Pitlick, J., Cui, Y., and Wilcock, P., 2009, Manual for computing bed load transport using BAGS (Bedload Assessment for Gravel-bed Streams) software: U.S. Forest Service, Rocky Mountain Research Station, Fort Collins, Colo., Gen. Tech. Rep. RMRS-GTR-223, 45 p.

Porter, S.C., and Swanson, T.W., 1998, Radiocarbon age constraints on rates of advance and retreat of the Puget lobe of the Cordilleran Ice Sheet during the last glaciation: Quaternary Research, v. 50, no. 3, p. 205-213.

Pringle, P.T., 2008, Roadside geology of Mount Rainier National Park and vicinity: Olympia, Wash., Washington Division of Geology and Earth Resources, 190 p.

Prych, E.A., 1988, Flood-carrying capacities and changes in channels of the lower Puyallup, White, and Carbon Rivers in western Washington: U.S. Geological Survey Water-Resources Investigations Report 87-4129, 43 p. (Also available at http://pubs.er.usgs.gov/publication/wri874129.)

Rasmussen, P.P., Gray, J.R., Glysson, G.D., and Ziegler, A.C., 2009, Guidelines and procedures for computing time-series suspended-sediment concentrations and loads from in-stream turbidity-sensor and streamflow data: U.S. Geological Survey Techniques and Methods, book 3, chap. C4, 53 p.

Redmond, K.T., and R.W. Koch, 1991, Surface climate and streamflow variability in the western United States and their relationship to large-scale circulation indices: Water Resources Research, v. 27, no. 9, p. 2,381-2,399.

Reid, L.M., and Dunne, T., 1984, Sediment production from forest road surfaces: Water Resources Research, v. 20, no. 11, p. 1,753-1,761.

Reid, L.M., and Dunne T., 1996, Rapid Evaluation of Sediment Budgets: Reiskirchen, Germany, Catena Verlag GMBH, 370 p.

Reid, M.E., Sisson, T.W., Brien, D.L., 2001, Volcano collapse promoted by hydrothermal alteration and edifice shape, Mount Rainier, Washington: Geology, v. 29, no. 9, pp. 779-782.

Reiners, P.W., Ehlers, T.A., Garver, J.I., Mitchell, S.G., Montgomery, D.R., Vance, J.A., and Nicolescu, S., 2002, Late Miocene exhumation and uplift of the Washington Cascade Range: Geology, v. 30, no. 9, p. 767-770.

Reneau, S.L., and Dietrich, W.E., 1991, Erosion rates in the southern Oregon coast range-Evidence for an equilibrium between hillslope erosion and sediment yield: Earth Surface Processes and Landforms, v. 16 , no. 4 , p. $307-322$.

Roberts, W.J., 1920, Flood control of White-Stuck and Puyallup Rivers, Inter-county river improvement: King and Pierce Counties, State of Washington, 76 p.

Roberts, R.G., and Church, M., 1986, The sediment budget in severely disturbed watersheds, Queen Charlotte Ranges, British Columbia: Canadian Journal of Forest Research, v. 16, no. 5, p. 1,0921,106 .

Salathé, E.P., 2006, Influences of a shift in North Pacific storm tracks on western North American precipitation under global warming: Geophysical Research Letters, v. 33, no. L19820, 4 p, doi:10.1029/2006gl026882.

Schmidt, J.C., and Wilcock, P.R., 2008, Metrics for assessing the downstream effects of dams: Water Resources Research, v. 44, no. W04404, 19 p., doi:10.1029/2006WR005092.

Schumm, S.A., 1965, Quaternary palaeohydrology, in Wright, H.E., and Frey, D.G., eds., Quaternary of the United States: Princeton, N.J, Princeton University Press, p. 783-794.

Schumm, S.A., 1977, The Fluvial System, Wiley-Interscience, New York, 338 p.

Scott, K.M., and Vallance, J.W., 1995, Debris flow, debris avalanche, and flood hazards at and downstream from Mount Rainier, Washington: U.S. Geological Survey Hydrologic Investigations Atlas 729, 2 pls., 9 p. (Also available at http://pubs.er.usgs.gov/publication/ha729.) 
Scott, K.M., Vallance, J.W., and Pringle, P.T., 1995, Sedimentology, behavior, and hazards of debris flows at Mount Rainier, Washington: U.S. Geological Survey Professional Paper 1547, 56 p. (Also available at http://pubs.er.usgs.gov/publication/pp1547.)

Sigafoos, R.S., and Hendricks, E.L., 1961, Botanical evidence of the modern history of Nisqually Glacier, Washington: U.S. Geological Survey Professional Paper 387-A, 20 p. (Also available at http://pubs.er.usgs.gov/publication/pp387A.)

Sigafoos, R. S., and E. L. Hendricks, 1972, Recent activity of glaciers of Mount Rainier, Washington: U.S. Geological Survey Professional Paper 387-B, 23 p. (Also available at http://pubs.er.usgs.gov/publication/pp387B.)

Sikonia, W.G., 1990, Sediment transport in the lower Puyallup, White, and Carbon Rivers of western Washington: U.S. Geological Survey Water-Resources Investigations Report 89-4112, 84 p. (Also available at http://pubs.er.usgs.gov/publication/wri894112.)

Singer, M.B., 2008, Downstream patterns of bed material grain size in a large, lowland alluvial river subject to low sediment supply: Water Resources Research, v. 44, no. W12202, 7 p., doi:10.1029/2008wr007183.

Sisson, T.W., Robinson, J.E., and Swinney, D.D., 2011, Whole-edifice ice volume change A.D. 1970 to 2007-2008 at Mount Rainier, Washington, based on LiDAR surveying: Geology, v. 39, no. 7, p. 639642, doi:10.1130/g31902.1.

Sisson, T.W. and Vallance, J.W., 2008, Frequent eruptions of Mount Rainier over the last 2,600 years: Bulletin of Volcanology, v. 71, no. 6, p. 595-681, doi:10.1007/s00445-008-0245-7.

Sisson, T.W., Vallance, J.W., and Pringle, P.T., 2001, Progress made in understanding Mount Rainier's hazards: Eos Transactions, v. 82, no. 9, p. 113, 118-120.

Sklar, L.S., Dietrich,W. E., Foufoula-Georgiou, E., Lashermes, B., and Bellugi, D., 2006, Do gravel-bed river size distributions record channel network structure?: Water Resources Research, v. 42, no. 6, no. W06D18, doi:10.1029/2006wr005035.

Sklar, L.S., Fadde, J., Venditti, J.G., Nelson, P., Wydzga, M.A., Cui, Y., and Dietrich, W.E., 2009, Translation and dispersion of sediment pulses in flume experiments simulating gravel augmentation below dams: Water Resources Research, v. 45, no. W08439, 14 p, doi:10.1029/2008wr007346.

Sobieszczyk, S., Uhrich, M.A., and Bragg, H.M., 2007, Major turbidity events in the North Santiam River basin, Oregon, water years 1999-2004: U.S. Geological Survey Scientific Investigations Report 2007-5178, 50 p. (Also available at http://pubs.er.usgs.gov/publication/sir20075178.)

Spicer, R.C., 1986, Glaciers in the Olympic Mountains, Washington-Present distributions and recent variations: Seattle, University of Washington: M.S. thesis, $158 \mathrm{p}$.

Toro-Escobar, M.E., Parker, G., and Paola, C., 1996, Transfer function for the deposition of poorly sorted gravel in response to streambed aggradation: Journal of Hydraulic Research, v. 34, no. 1, p. 35-54.

Trimble, S.W., 1999, Decreased rates of alluvial sediment storage in the Coon Creek Basin, Wisconsin, 1975-93: Science, v. 285, no. 5431, p. 1,244-1,246, doi:10.1126/science.285.5431.1244.

Turner, T.R., Duke, S.D., Fransen, B.R., Reiter, M.L., Kroll, A.J., Ward, J.W., Bach, J.L., Justice, T.E., and Bilby, R.E., 2010, Landslide densities associated with rainfall, stand age, and topography on forested landscapes, southwestern Washington, USA: Forest Ecology and Management, v. 259, p. 2,233-2,247, doi:/10.1016/j.foreco.2010.01.051.

University of Washington, 2012, Pacific Decadal Oscillation Database: Joint Institute for the Study of the Atmosphere and Ocean, accessed May 4, 2012, at http://jisao.washington.edu/pdo/.

University of Wyoming, 2011, College of Engineering, Department of Atmospheric Science web site, accessed November 8, 2011, at http://weather.uwyo.edu/upperair/sounding.html. 
U.S. Army Corps of Engineers, 2009, Mud Mountain Dam-White and Puyallup Rivers channel capacity study: Seattle, Wash., U.S. Army Corps of Engineers, 25 p.

U.S. Department of Agriculture, 2011, National Agricultural Imagery Program: U.S. Department of Agriculture web site, accessed August 24, 2012, at http://www.fsa.usda.gov/FSA/apfoapp? area=home\&subject=prog\&topic=nai.

U.S. Geological Survey, 2011, StreamStats: U.S. Geological Survey database, accessed August 24, 2012, at http://water.usgs.gov/osw/streamstats/Washington.html.

U.S. Geological Survey, 2012a, Earth Resources and Observation (EROS) Center: U.S. Geological Survey database, accessed August 24, 2012, at http://eros.usgs.gov/\#/Find_Data/Products_and_Data_Available.

U.S. Geological Survey, 2012b, National Water Information System: U.S. Geological Survey database, accessed August 24, 2012, at http://waterdata.usgs.gov/wa/nwis/nwis.

Vallance, J.W., and Scott, K.M., 1997, The Osceola Mudflow from Mount Rainier-Sedimentology and hazard implications of a huge clay-rich debris flow: Geological Society of America Bulletin, v. 109, no. 2, p. 143-163.

Varnes, D.J., 1978, Slope movement types and processes, in Schuster, R.L., and Krizek, R.J., eds., Landslides-Analysis and control: Washington, D.C., National Academy of Sciences, p. 11-33.

Veatch, F. M., 1971, Analysis of a 24-year photographic record of Nisqually Glacier, Mount Rainier National Park, Washington: U.S. Geological Survey Professional Paper 631, 52 p. (Also available at http://pubs.er.usgs.gov/publication/pp631.)

Wagner, R.J., Boulger Jr., R.W., Oblinger, C.J., Smith, B.A., 2006, Guidelines and standard procedures for continuous water-quality monitors-Station operation, record computation, and data reporting: U.S. Geological Survey Technical Manual 1-D3, 51 p.

Walder, J.S., and Driedger, C.L., 1994, Rapid geomorphic change caused by glacial outburst floods and debris flows along Tahoma Creek, Mount Rainier, Washington, U.S.A.: Arctic and Alpine Research, v. 26 , no. 4 , p. 319-327.

Wallick, J.R., O'Connor, J.E., Anderson, S., Keith, M., Cannon, C., and Risley, J.C., 2011, Channel change and bed-material transport in the Umpqua River basin, Oregon: U.S. Geological Survey Scientific Investigations Report 2011-5041, 112 p. (Also available at http://pubs.er.usgs.gov/publication/sir20115041.)

Wemple, B.C., Swanson, F.J., and Jones, J.A., 2001, Forest roads and geomorphic process interactions, Cascade Range, Oregon: Earth Surface Processes and Landforms, v. 26, p. 191-204.

Wilcock, P.R., and Crowe, J.C., 2003, Surface-based transport model for mixed-size sediment: Journal of Hydraulic Engineering, v. 129, no. 2, p. 120-128, doi:10.1061/ ASCE!0733-9429 2003!129:2 120!.

Wise, D.R., Rinella, F.A., III, Rinella, J.F., Fuhrer, G.J., Embrey, S.S., Clark, G.E., Schwarz, G.E., and Sobieszczyk, S., 2007, Nutrient and suspended-sediment transport and trends in the Columbia River and Puget Sound basins, 1993-2003: U.S. Geological Survey Scientific Investigations Report 20075186, 117 p. (Also available at http://pubs.er.usgs.gov/publication/sir20075186.)

Wolman, M.G., 1954, A method of sampling coarse river-bed material: Transactions of the American Geophysical Union, v. 35, no. 6, p. 951-956.

Wu, W., and Wang, S.S.Y., 2006, Formulas for sediment porosity and settling velocity: Journal of Hydraulic Engineering, v. 132, no. 8, p. 858-862, doi:10.1061/(asce)0733-9429(2006)132:8(858). 


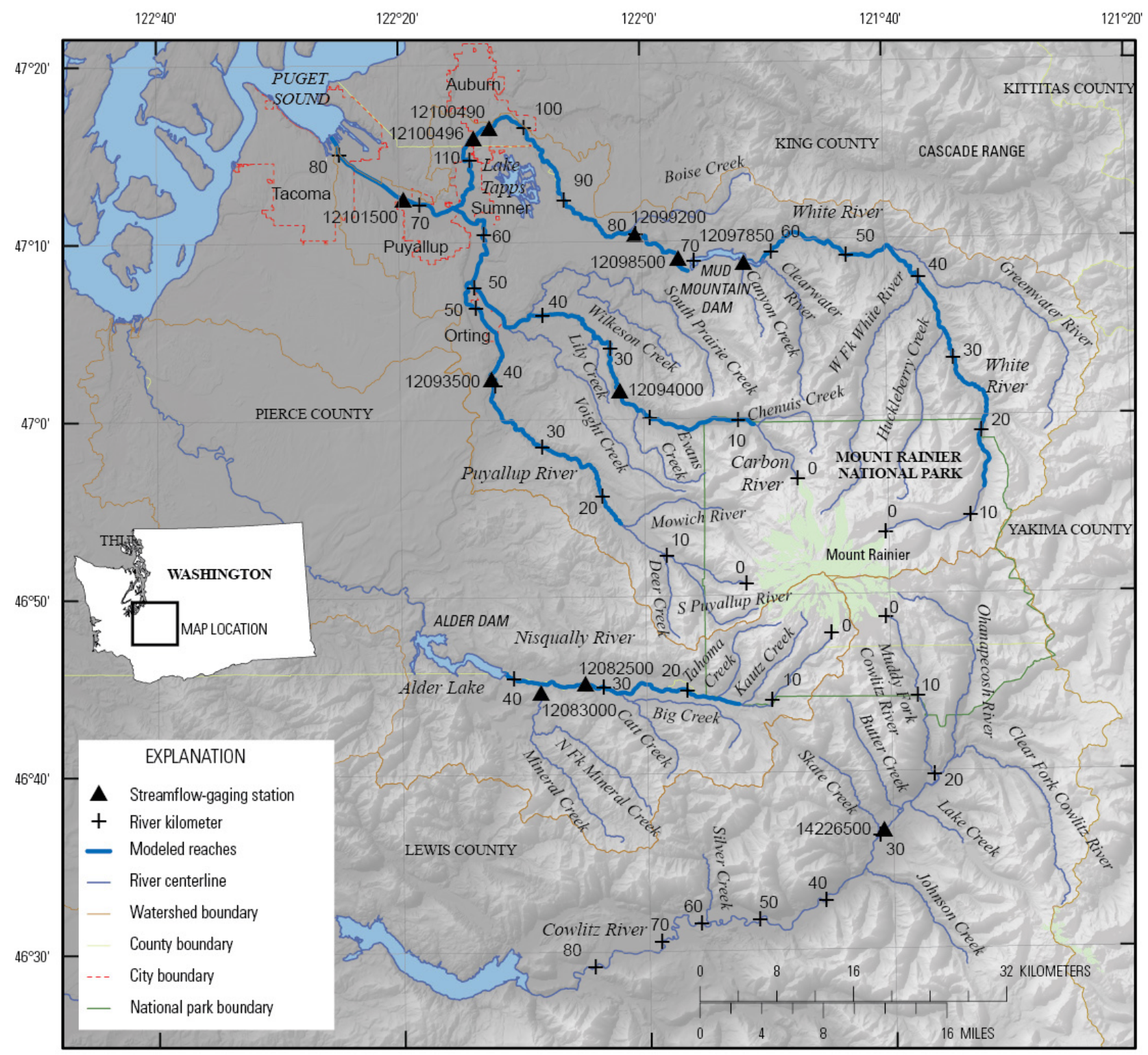

Figure 1. Map showing rivers, basin boundaries, U.S. Geological Survey streamflow-gaging stations, and tributaries draining Mount Rainier, Washington, along with river stationing used in the this study. 


\section{Processes affecting sediment delivery from Mount Rainier, Washington}

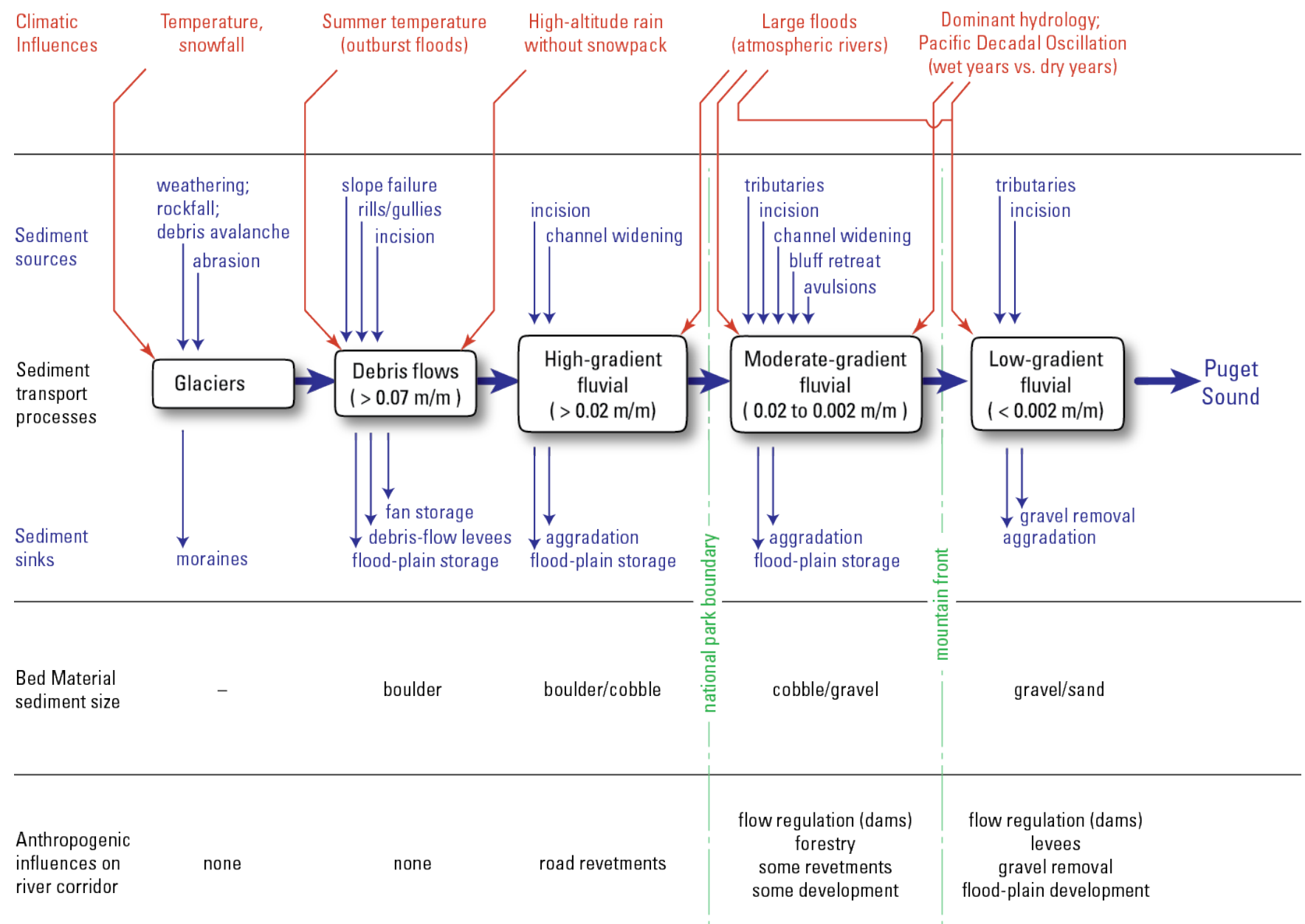

Figure 2. Conceptual model of processes affecting sediment delivery from Mount Rainier, Washington. 

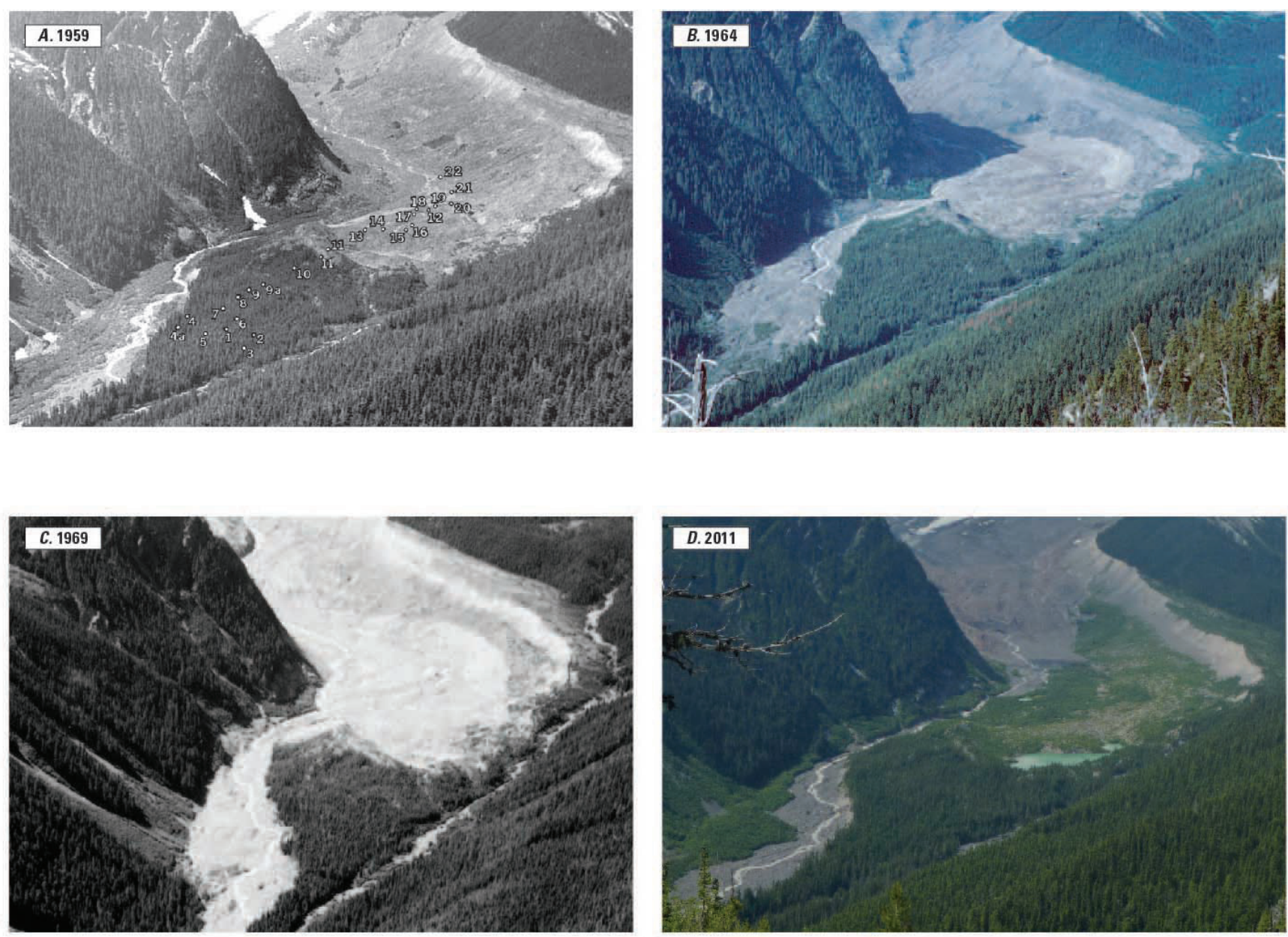

Figure 3. Images of the headwaters of the White River at the terminus of the Emmons Glacier, Mount Rainier, Washington: (A) July 18, 1959 (published by Sigafoos and Hendricks, 1961; numbered points indicate botanical study locations), (B) 1964 (photo by D.R. Crandell), (C) August 29, 1969 (published by Sigafoos and Hendricks, 1972), and (D) August 14, 2011 (photo by C.S. Magirl). 

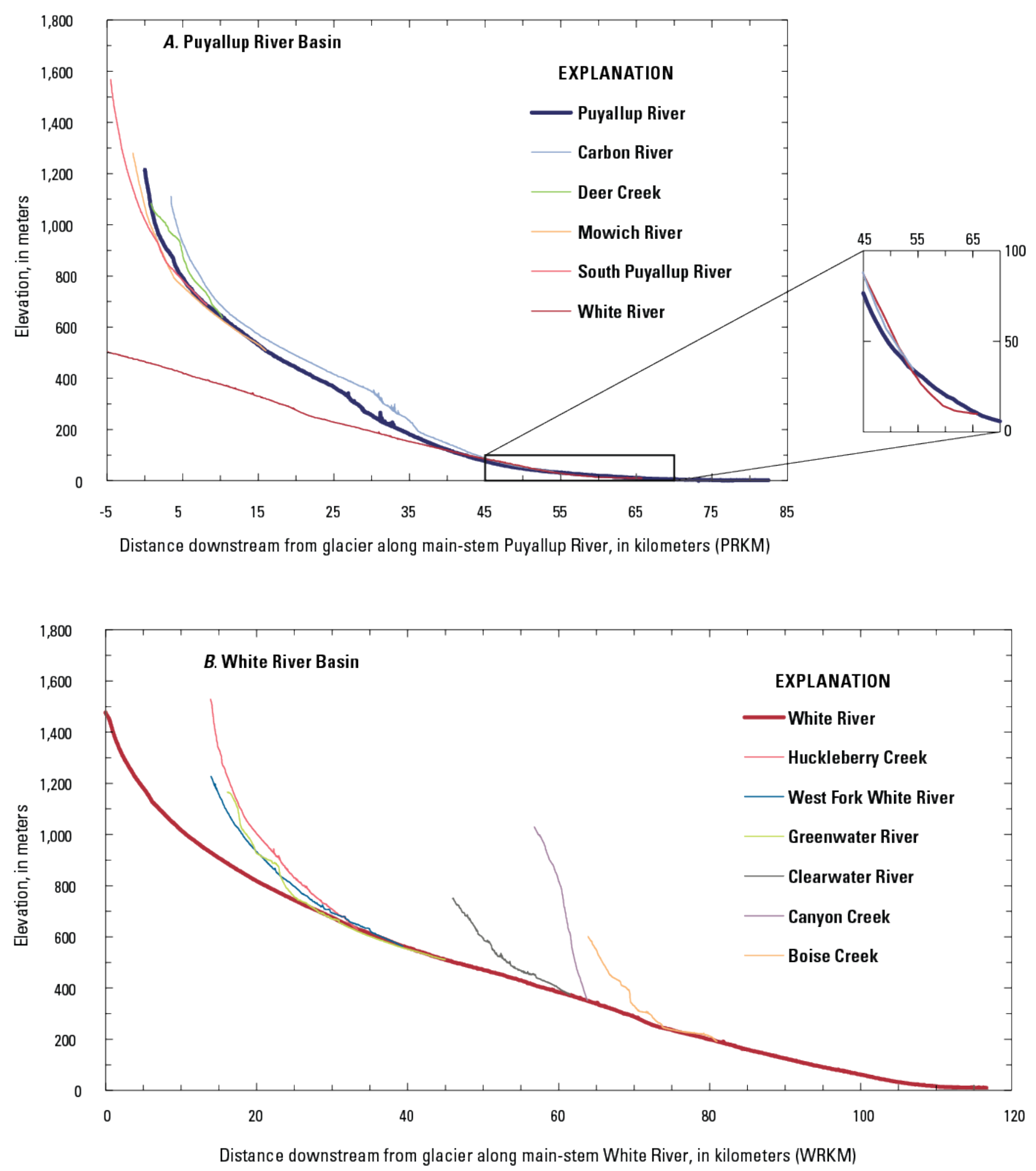

Figure 4. Graph showing river elevation profiles for main-stem rivers and tributaries of the (A) Puyallup, (B) White, (C) Carbon, (D) Nisqually, and (E) Cowlitz Rivers, Washington. 

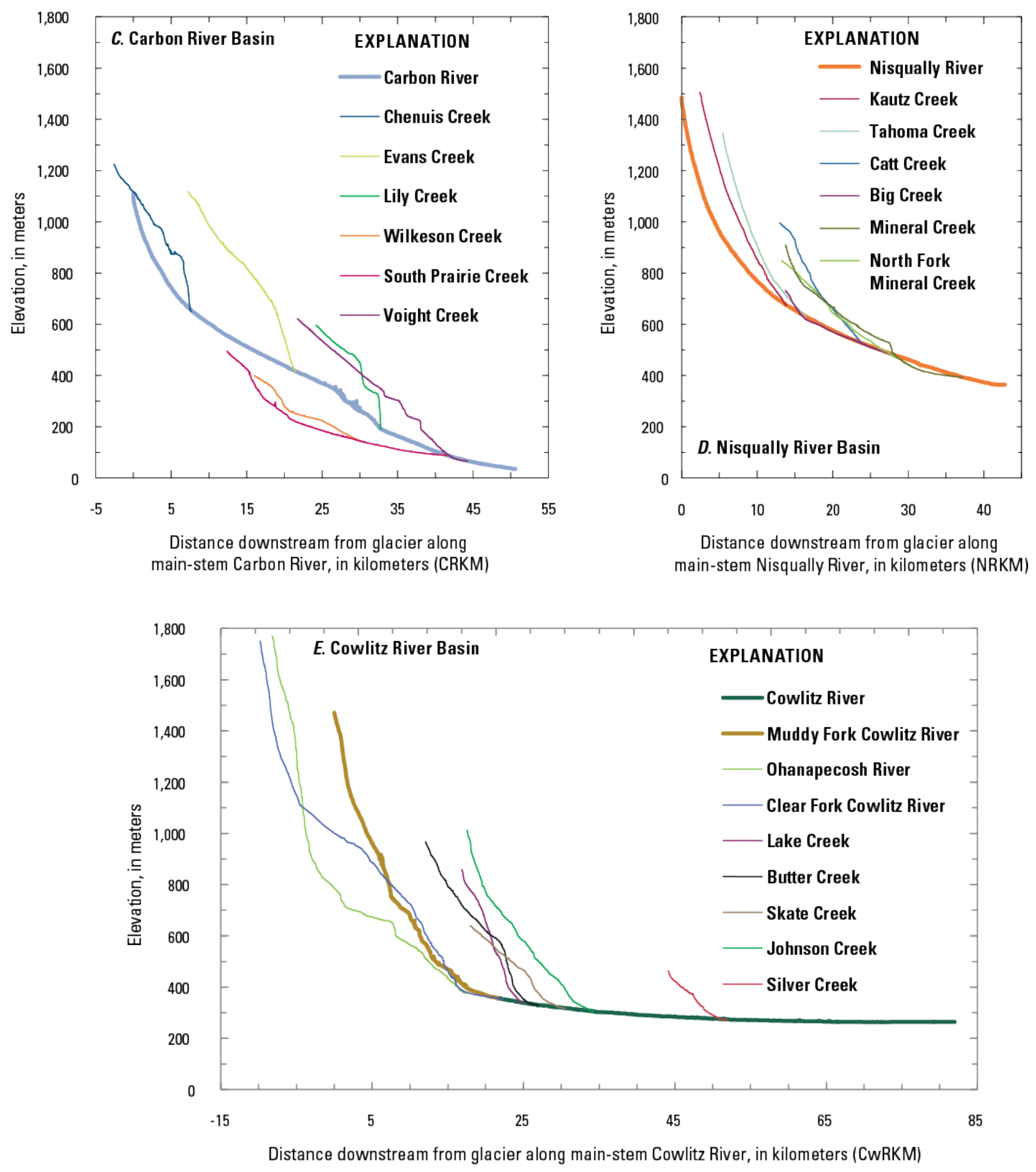

Figure 4. Graph showing river elevation profiles for main-stem rivers and tributaries of the (A) Puyallup, (B) White, (C) Carbon, (D) Nisqually, and (E) Cowlitz Rivers, Washington.-continued 

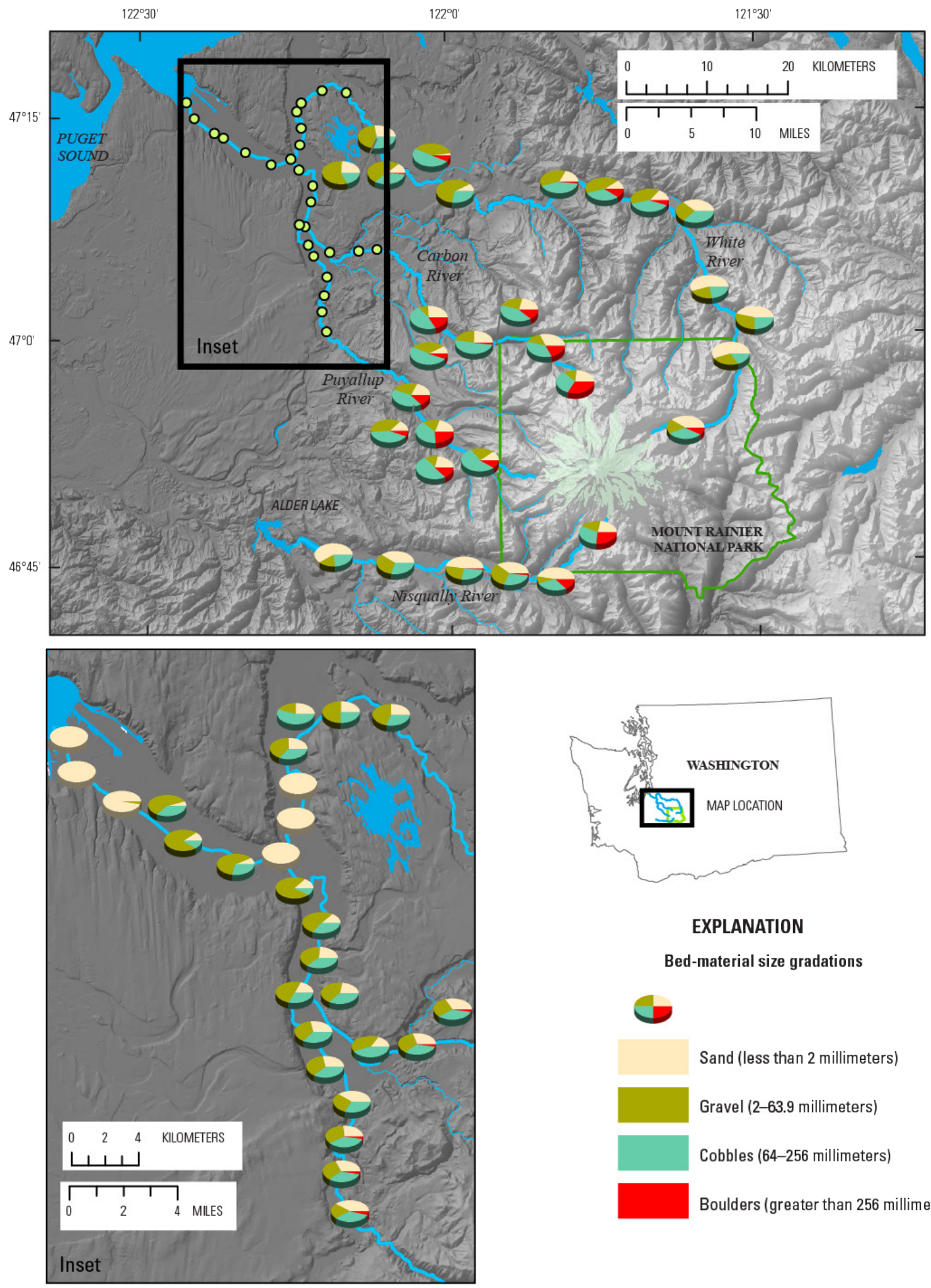

\section{EXPLANATION}

Bed-material size gradations

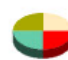

Sand (less than 2 millimeters)

Gravel (2-63.9 millimeters)

Cobbles (64-256 millimeters)

Boulders (greater than 256 millimeters)

Figure 5. Graph showing bed-material size gradations of the Puyallup, Carbon, White, and upper Nisqually Rivers, Washington. 

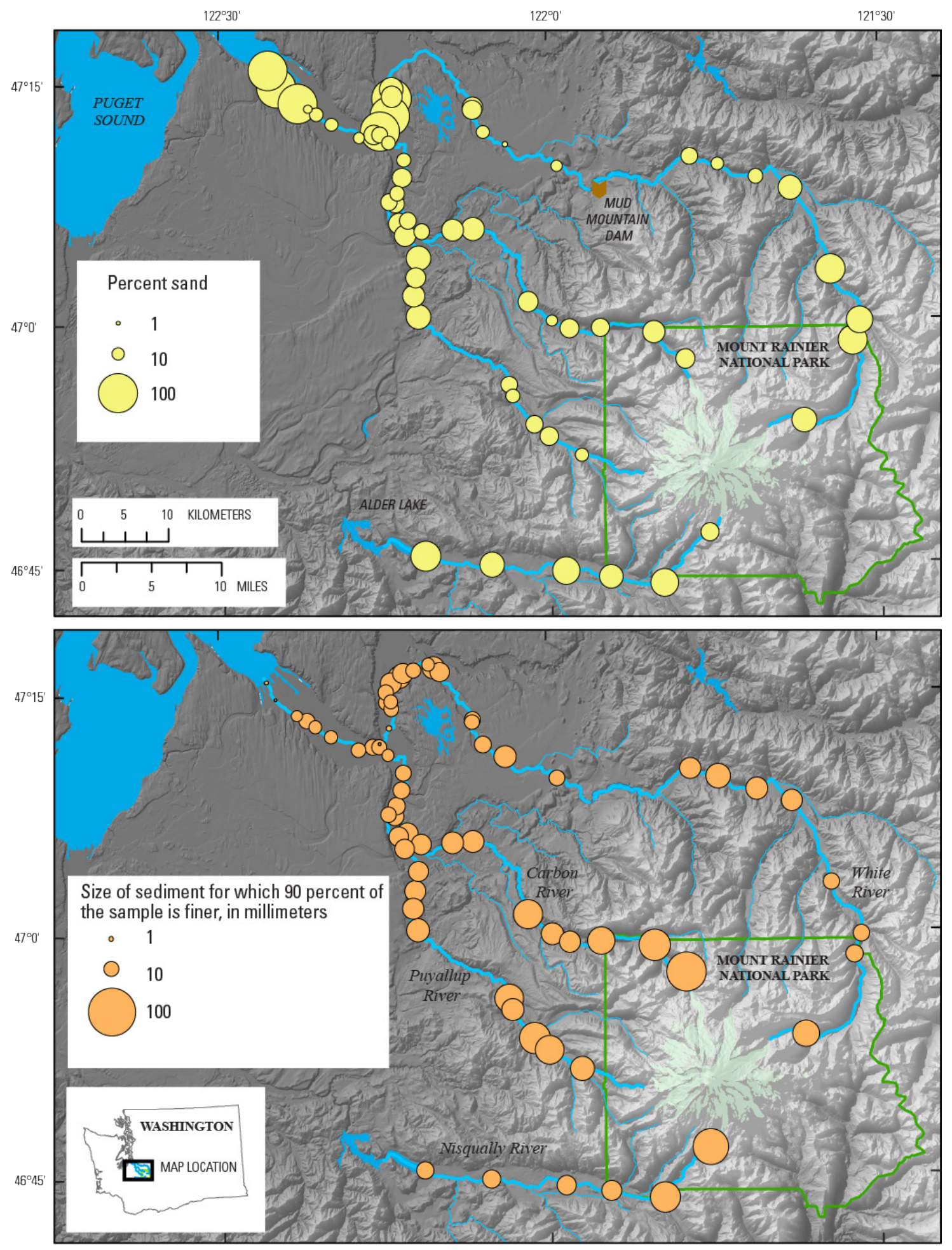

Figure 6. Maps showing bed-material size gradations of the Nisqually, Carbon, Puyallup, and White Rivers, Washington: (A) percentage of sand in bed-surface sediment and (B) D90 size of bed-surface sediment (only including sizes greater than $2 \mathrm{~mm}$ ). 

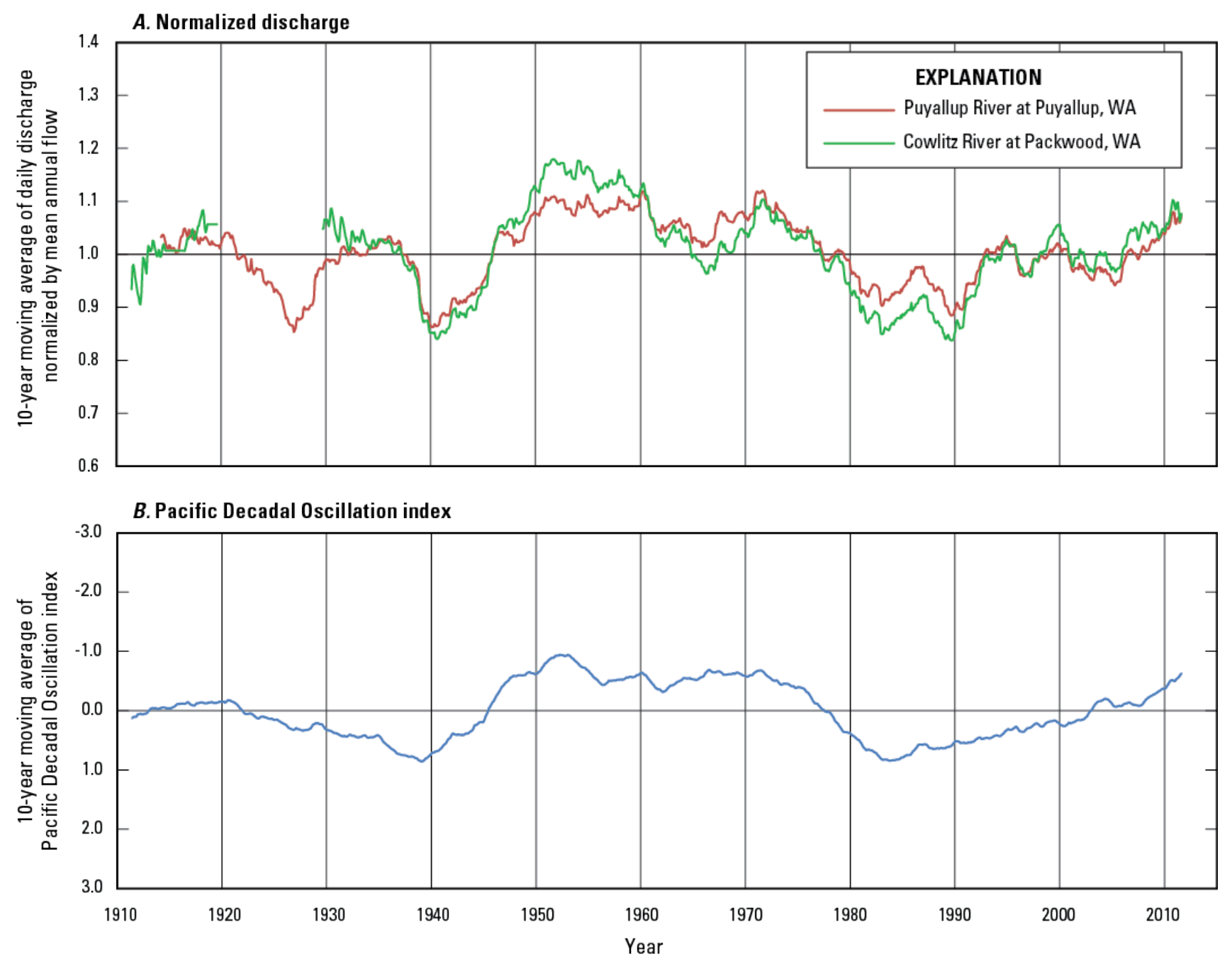

Figure 7. Graphs showing (A) Hydrologic conditions during the 20th century in the Mount Rainier, Washington, catchment as reflected in 10-year moving-average daily-discharge values, normalized by the mean annual flow, for U.S. Geological Survey streamflow-gaging stations Puyallup River at Puyallup (12101500) and the Cowlitz River at Packwood (14226500); and (B) 10-year moving average of sea surface temperatures in the northern Pacific Ocean as reflected with the Pacific Decadal Index. 

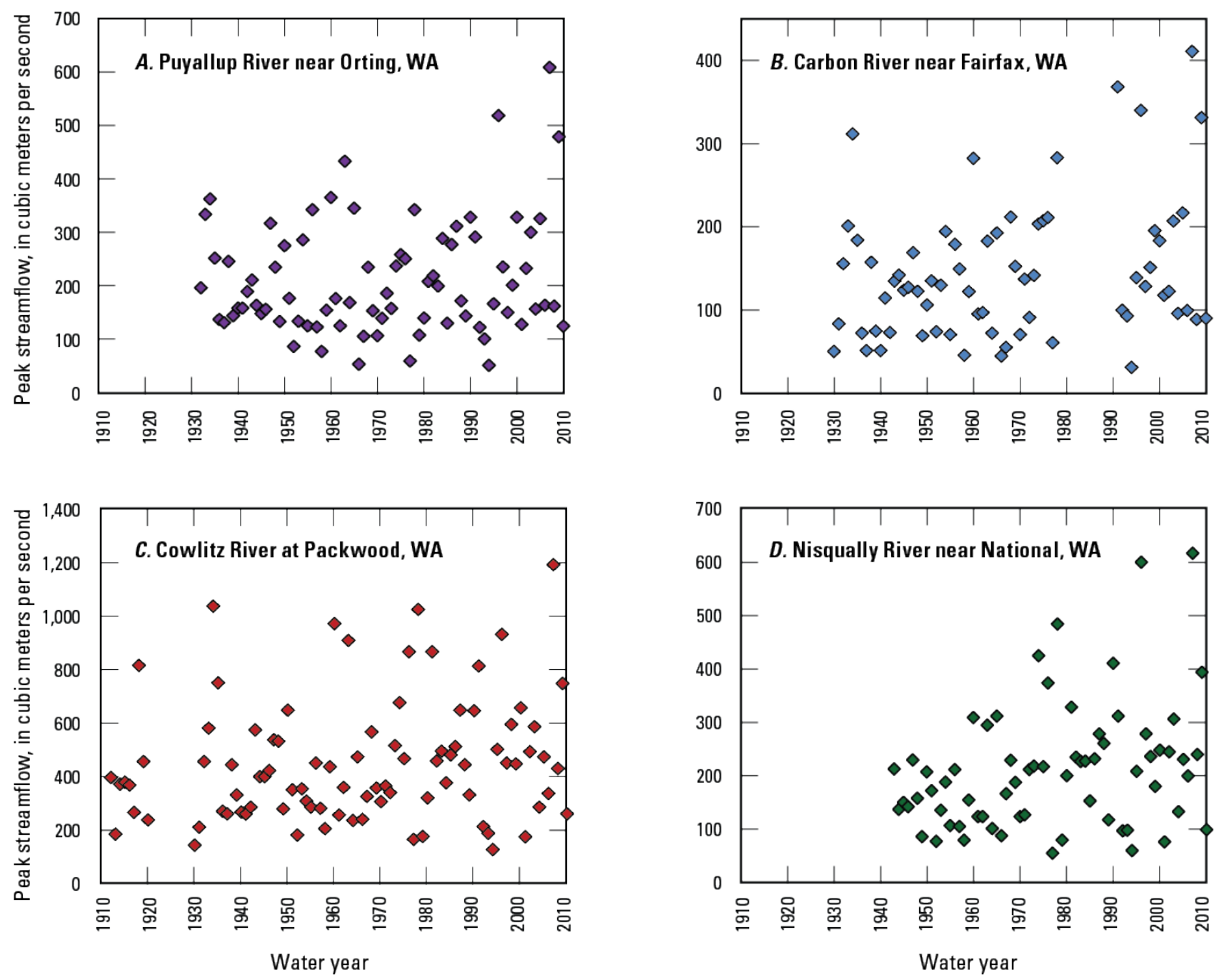

Figure 8. Graph showing annual peak flows for U.S. Geological Survey streamflow-gaging stations on unregulated section of the main-stem rivers draining Mount Rainier, Washington: (A) the Puyallup River near Orting gage (12093500), (B) the Carbon River near Fairfax gage (12094000), (C) the Cowlitz River at Packwood gage (14226500), and (D) the Nisqually River near National gage (12082500). 


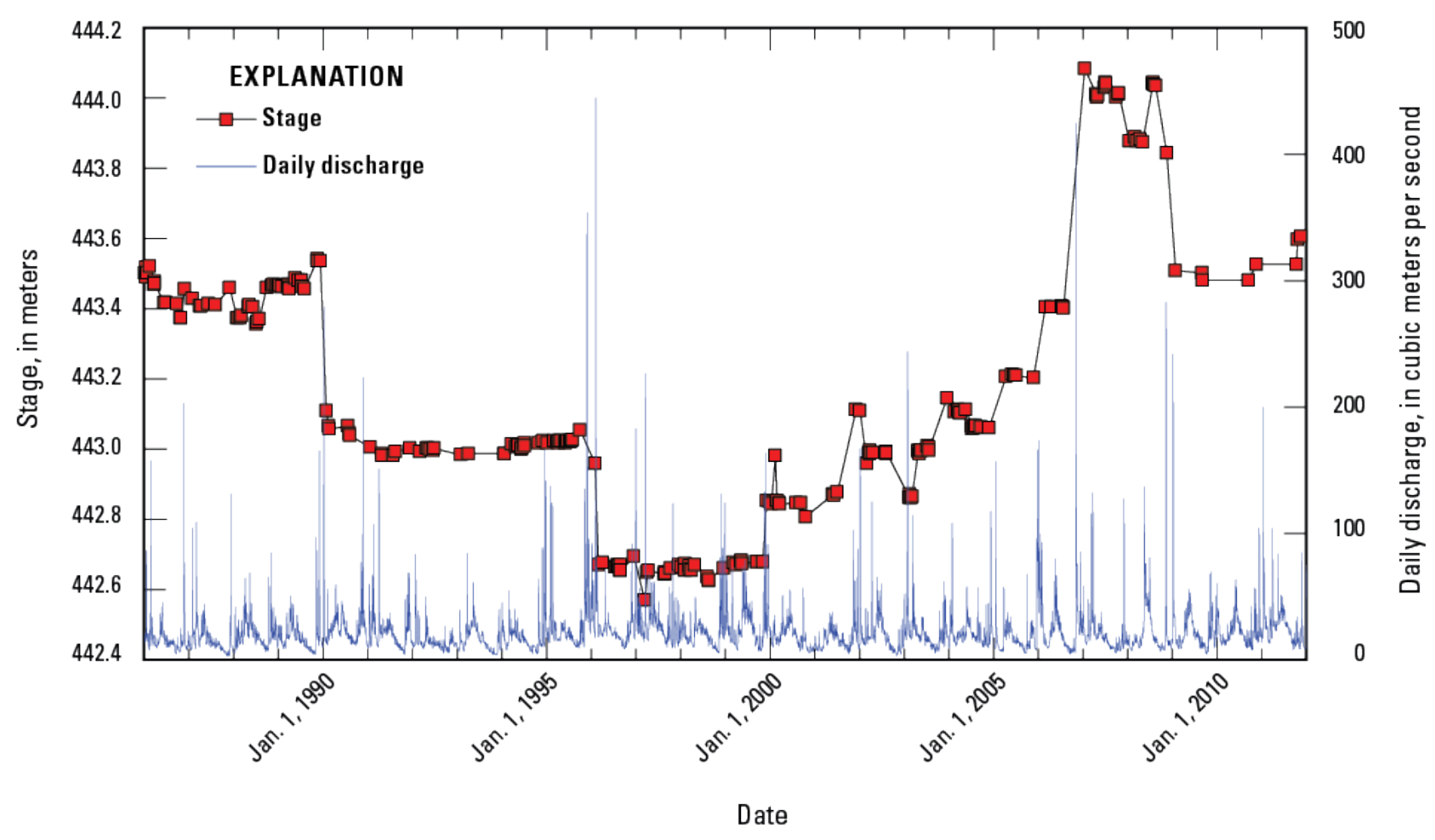

Figure 9. Graph showing stage for median flow and daily discharge as measured at the U.S. Geological Survey streamflow-gaging station Nisqually River near National (12082500). 


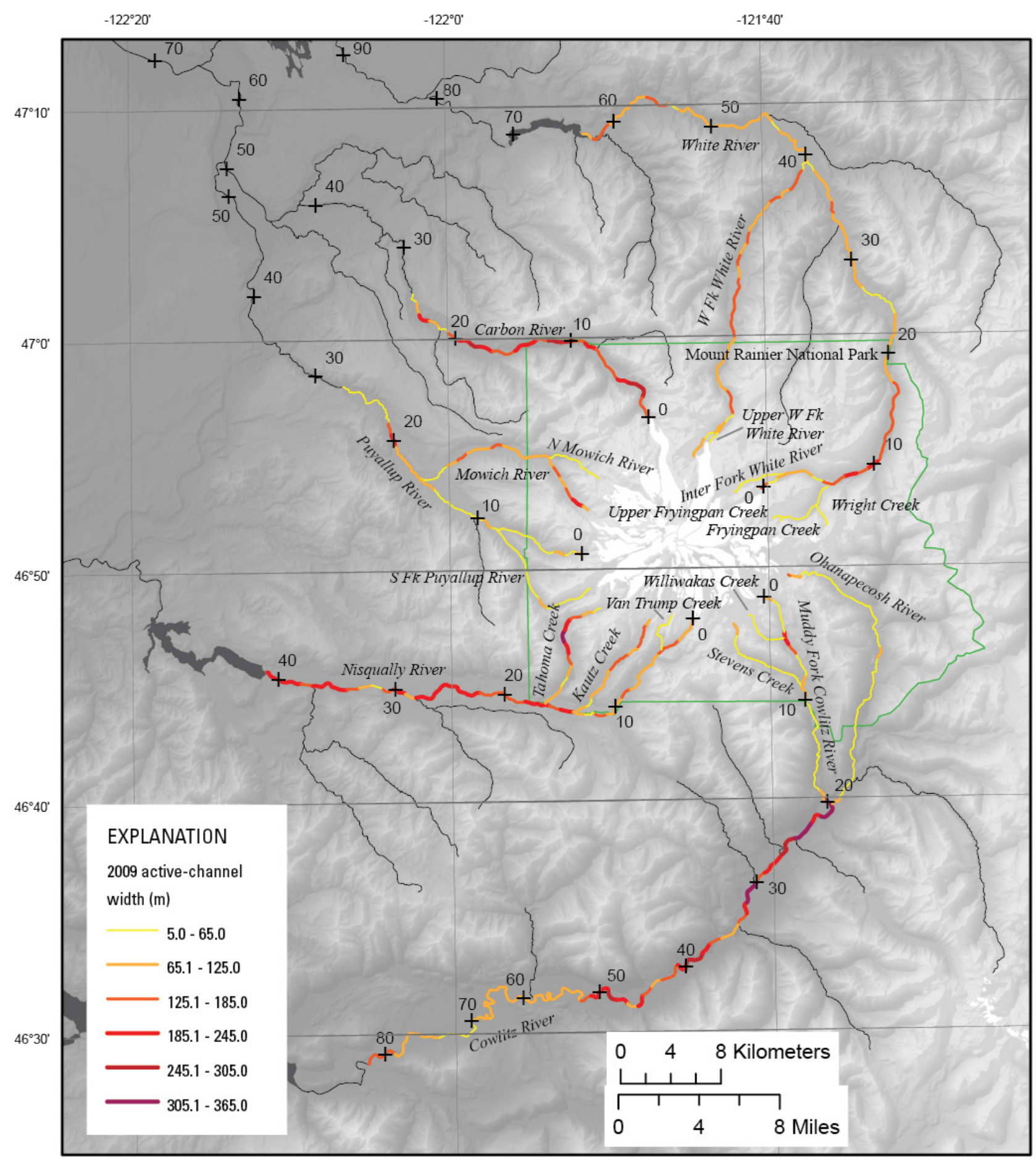

Figure 10. Map showing active-channel width in 2009 of rivers draining Mount Rainier, Washington. 
Mean active-channel width, in meters

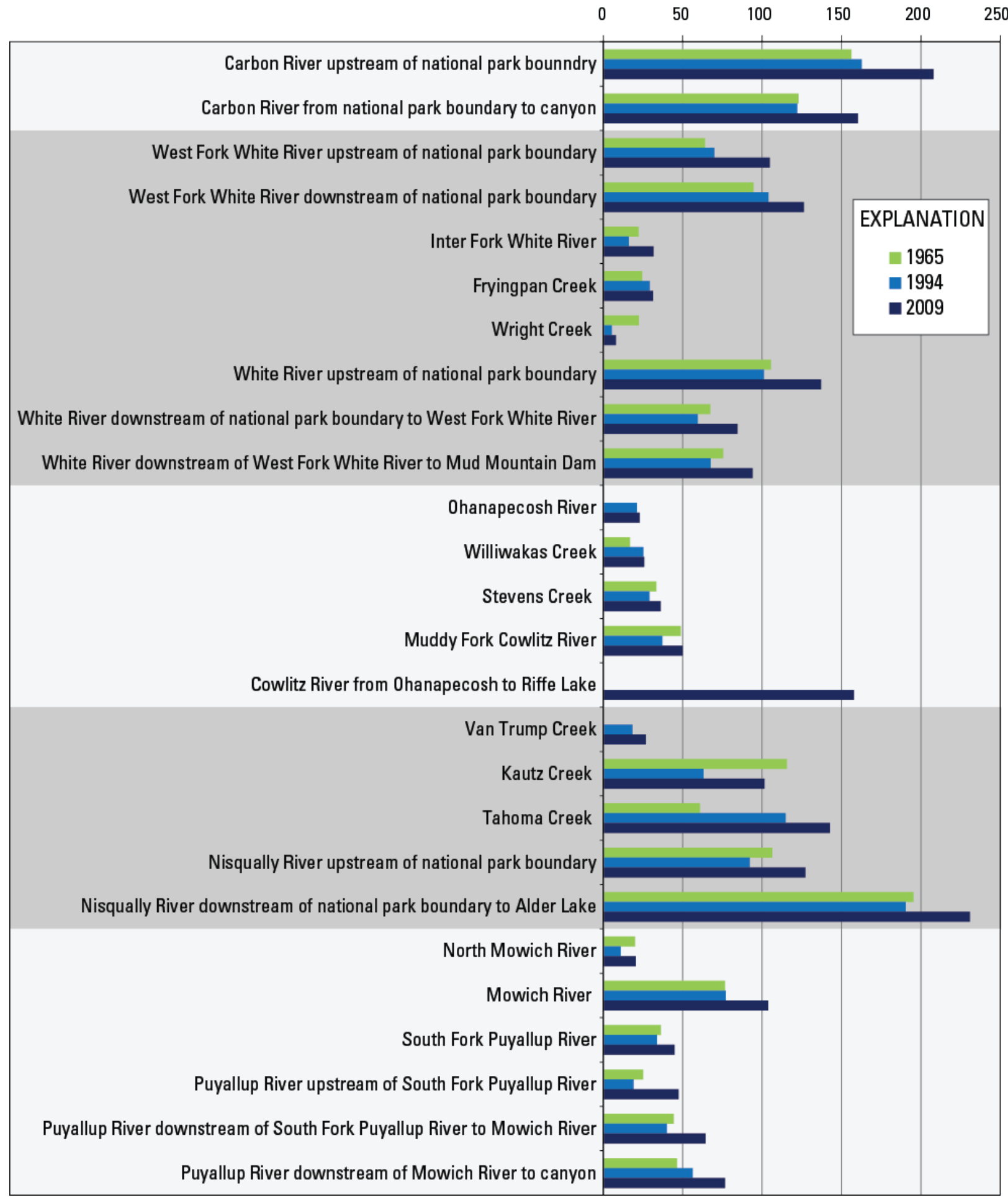

Figure 11. Graph showing active-channel width from 1965, 1994, and 2009 of rivers draining Mount Rainier, Washington. 


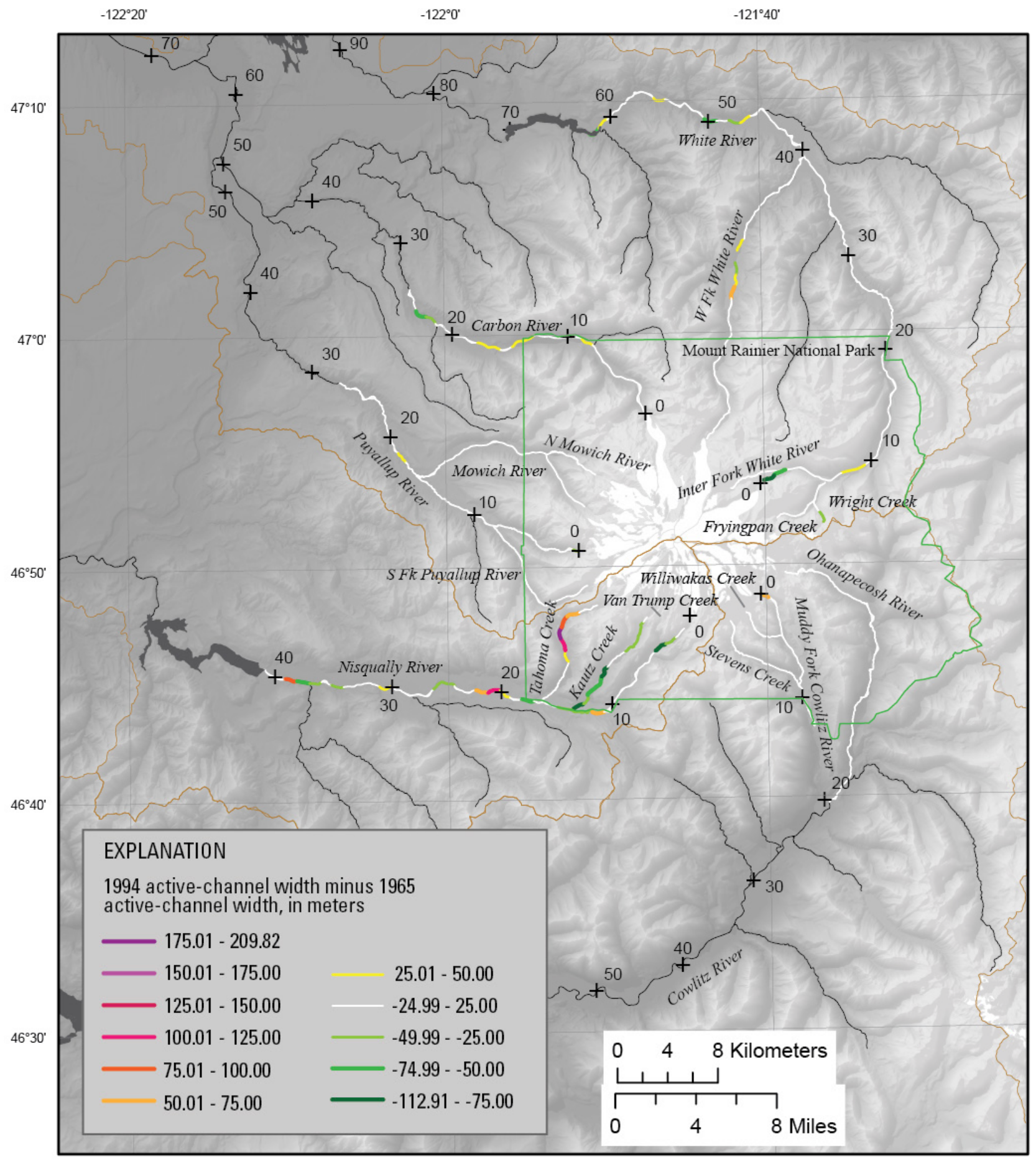

Figure 12. Map showing change in active-channel width from 1965 to 1994 for rivers draining Mount Rainier, Washington. 


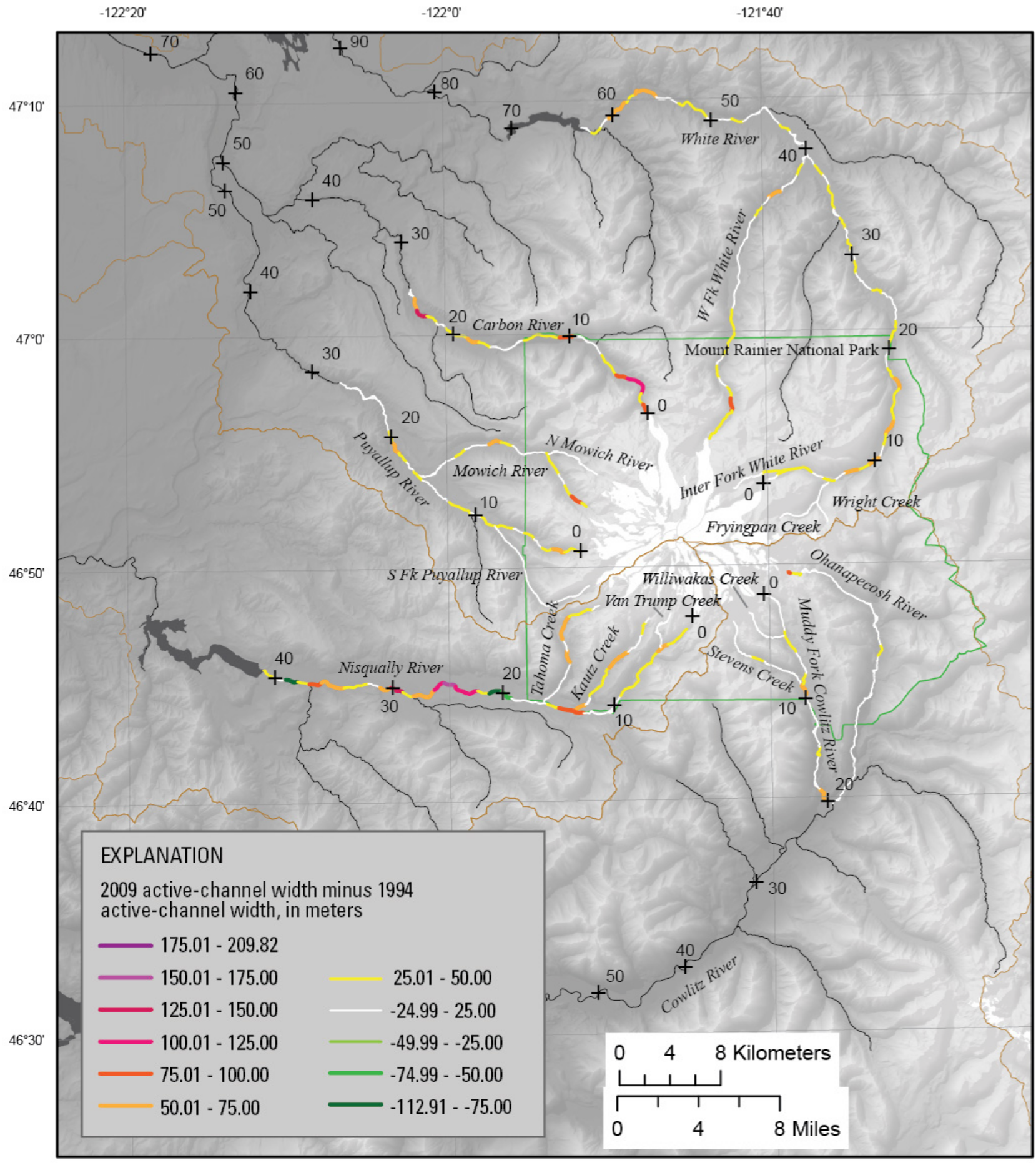

Figure 13. Map showing change in active-channel width from 1994 to 2009 for rivers draining Mount Rainier, Washington. 

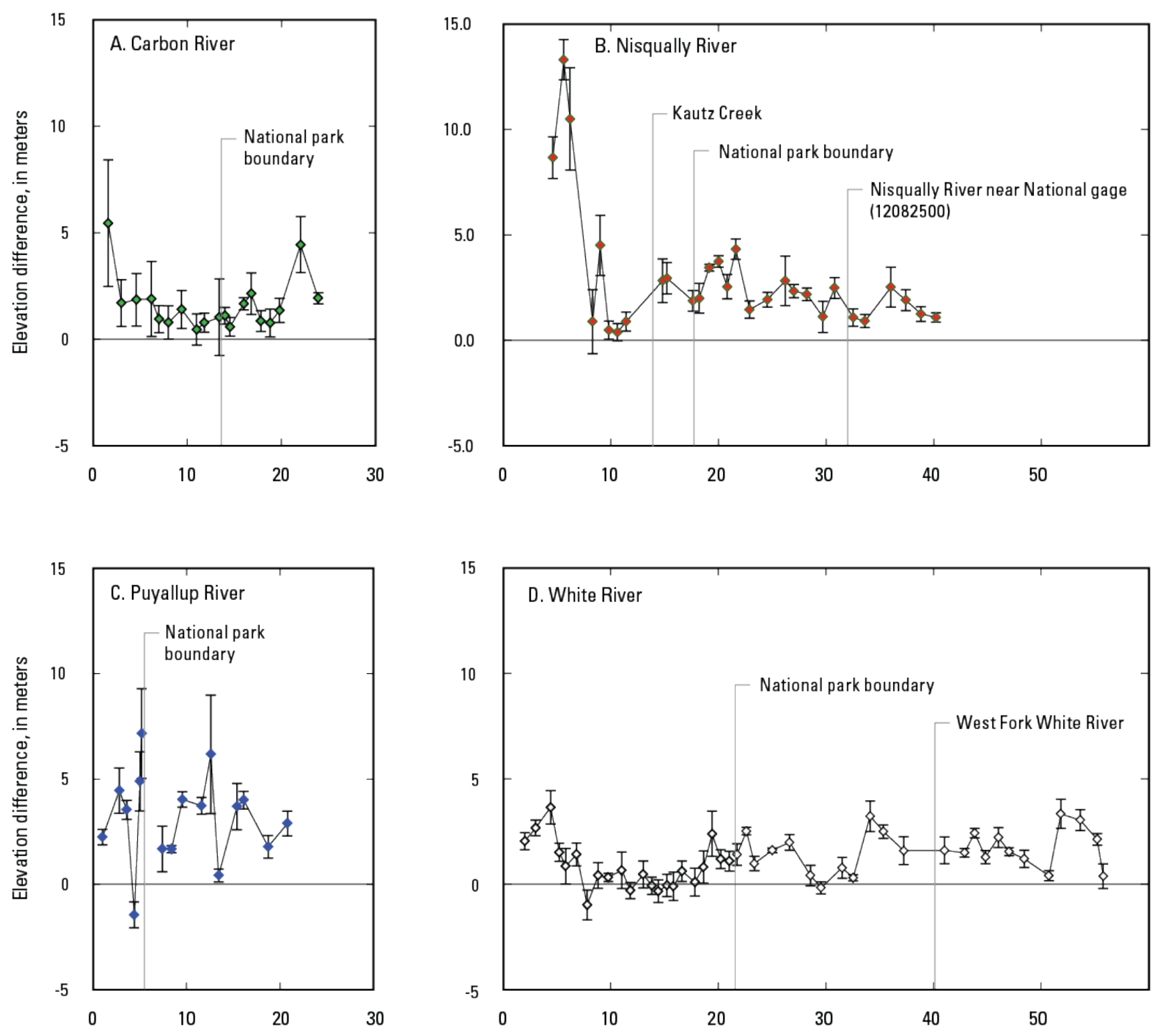

Distance downstream of glacier, in kilometers

Figure 14. Graph showing the difference in elevation between the forested terrace adjacent to the active channel and the active channel for the (A) Carbon River, (B) Nisqually River, (C) Puyallup River, and (D) White River, Washington. Error bars represent one standard deviation of elevation data from forested terrace. All elevation data taken from available light detection and ranging digital elevation models. 


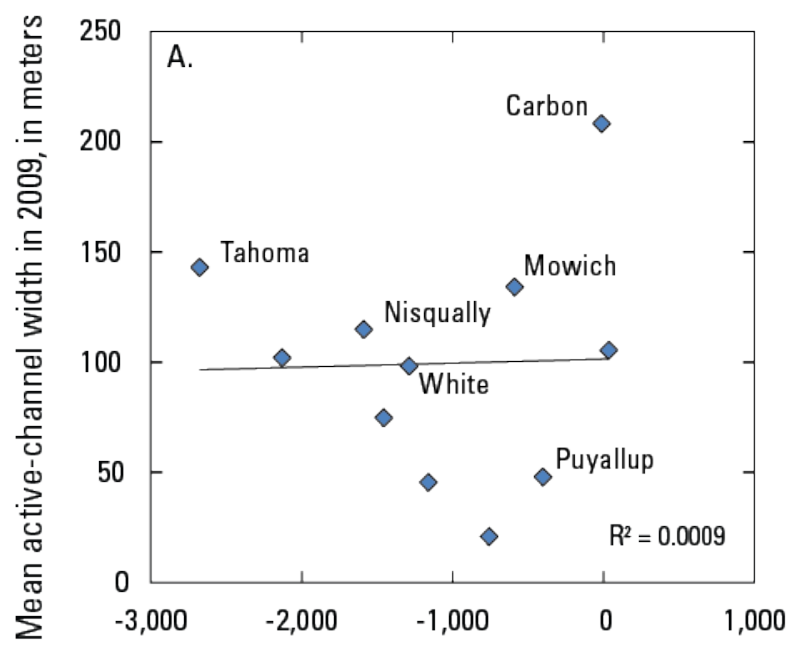

Total glacier retreat, $1913-1994$, in meters

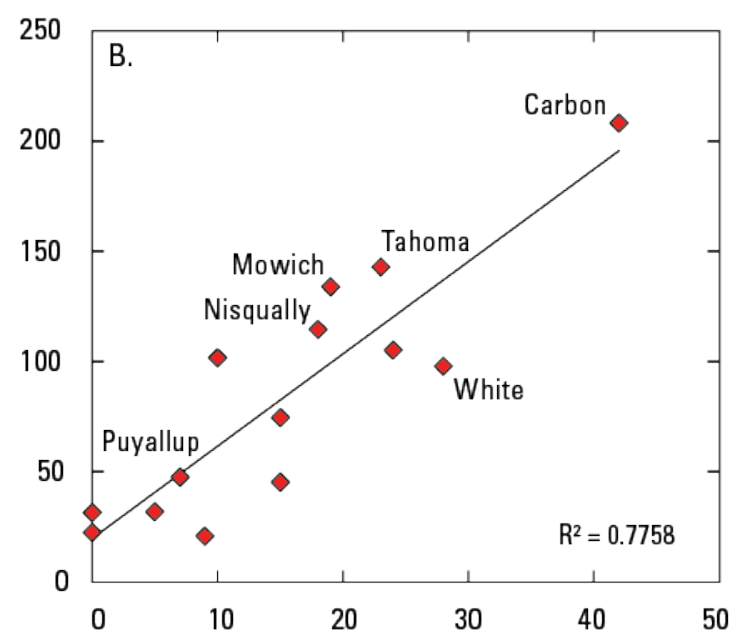

Spatial coverage of superglacial debris, 1971, in percent

Figure 15. Graph showing active-channel width of rivers draining Mount Rainier, Washington, in 2009 versus (A) total glacier retreat from 1913 to 1994 of river's primary glacier source and (B) percentage of mantling of superglacial debris on river primary glacier source. All glacier data by Nylen (2004). 


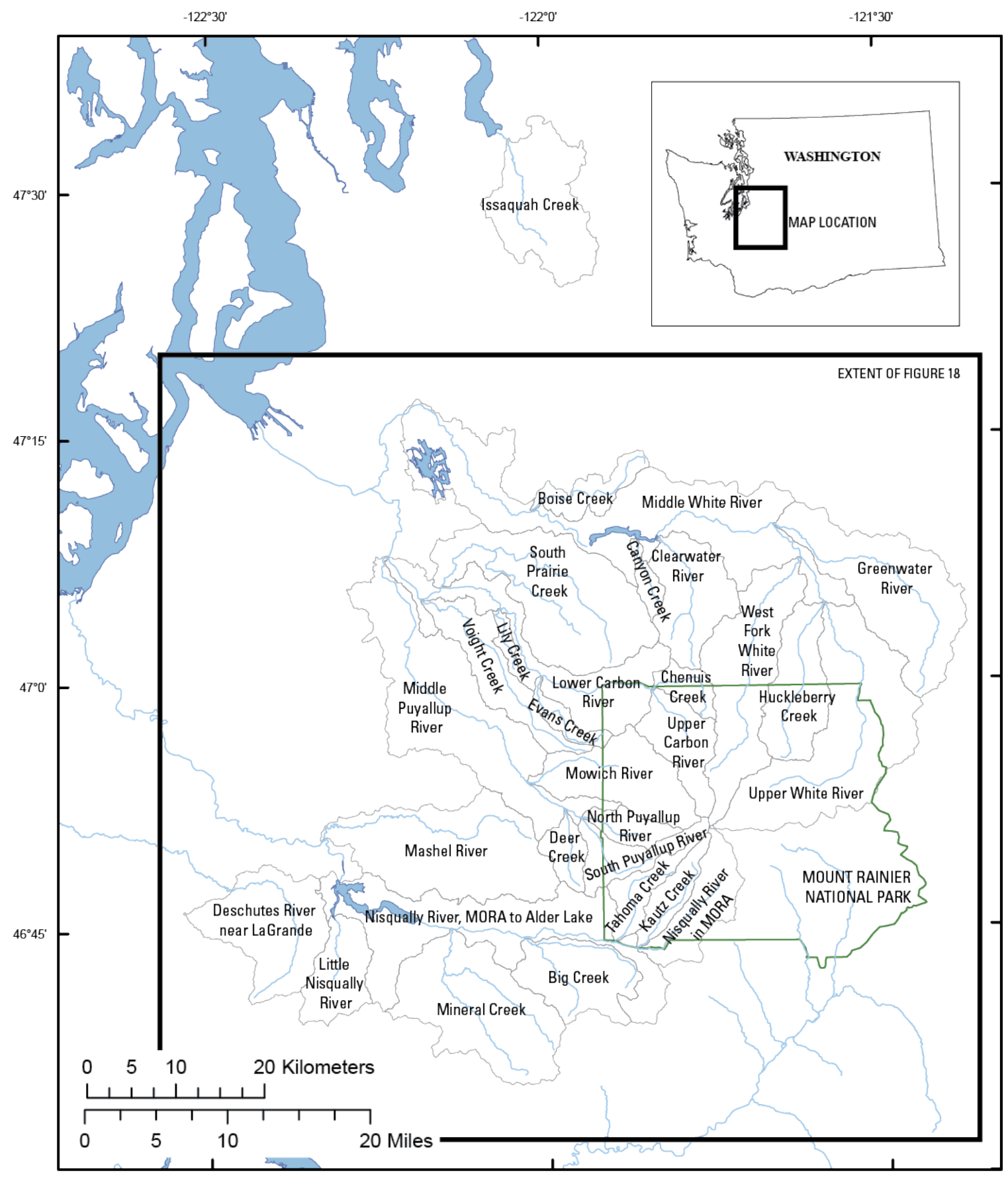

Figure 16. Map showing location of 27 subcatchments analyzed to calculate sediment-production potential and the three additional subcatchments used for calibration. (MORA stands for Mount Rainier National Park.) 


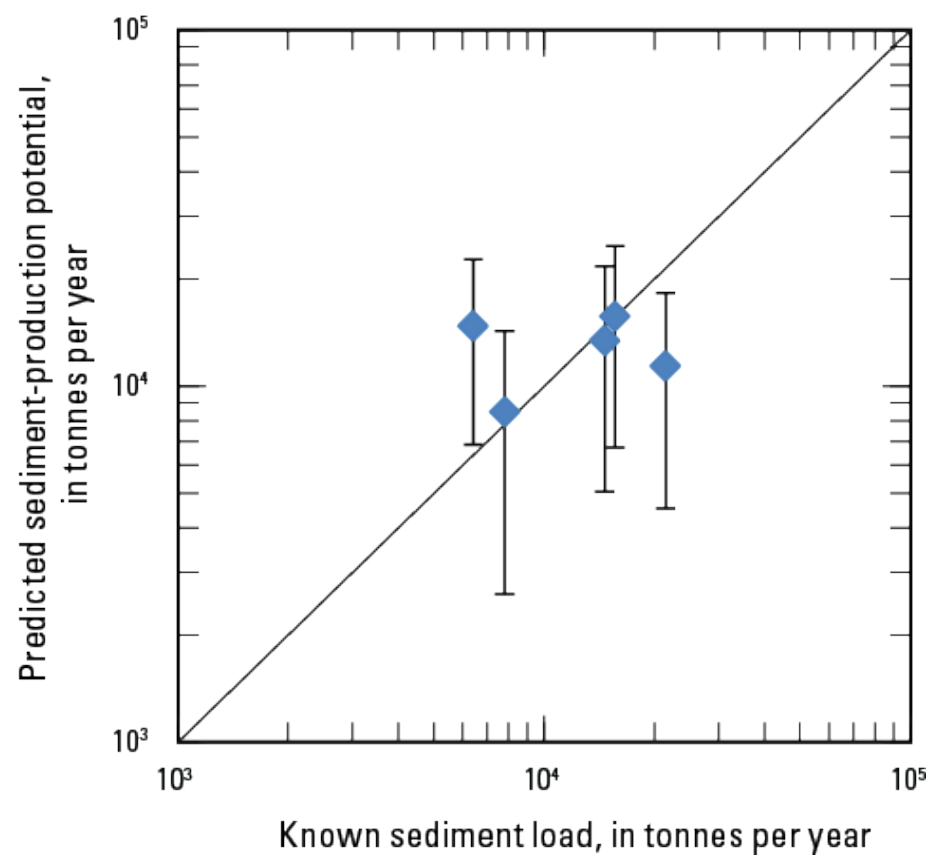

Figure 17. Graph showing relation between the predictions of sediment-production potential from five calibration subcatchments and the measured total sediment load. Error bars represent uncertainty in the sediment-load predictions. The diagonal line represents perfect agreement between predictions and actual loads. 


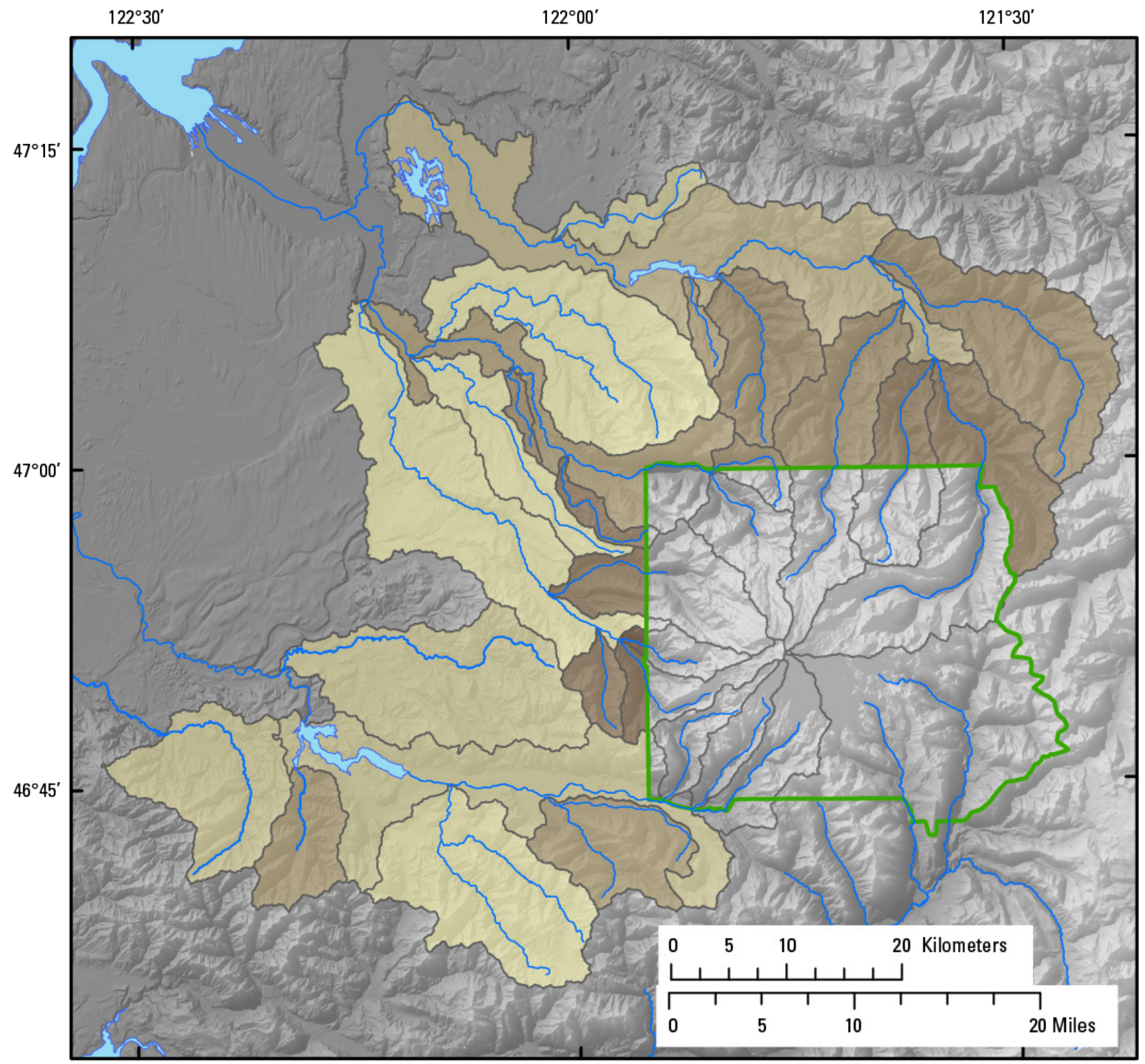

EXPLANATION
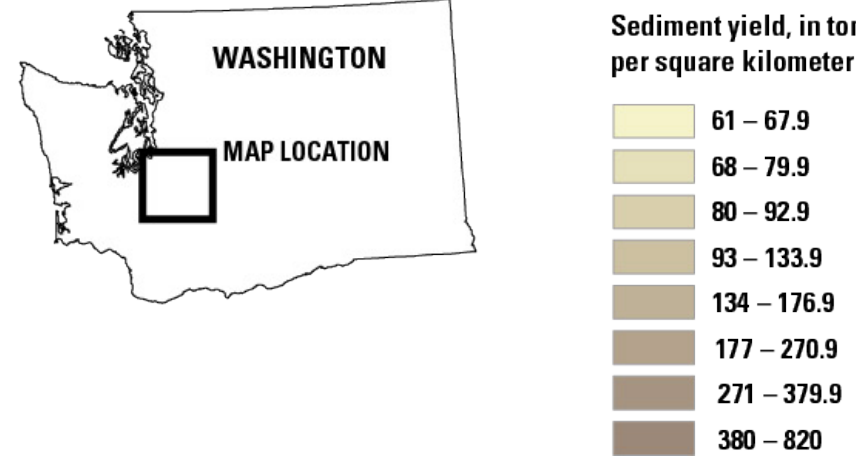

Figure 18. Map showing predicted sediment-production yield from roads, landslides, and soil creep for mountainous subcatchments outside Mount Rainier National Park that contribute to the Puyallup, Carbon, and White Rivers and the upper Nisqually River. 

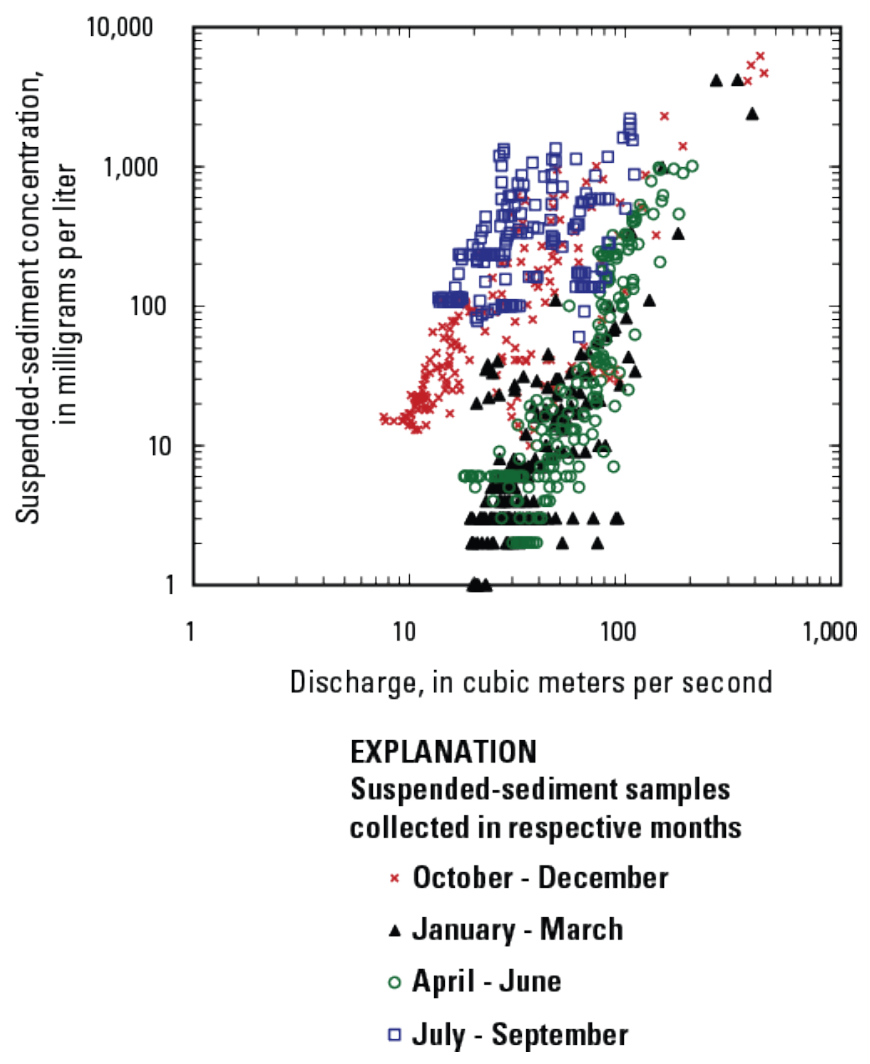

Figure 19. Graph showing suspended-sediment concentration versus discharge as collected in 1974-1976 by Nelson (1978) at U.S. Geological Survey streamflow-gaging station White River below Clearwater River near Buckley (12097850).

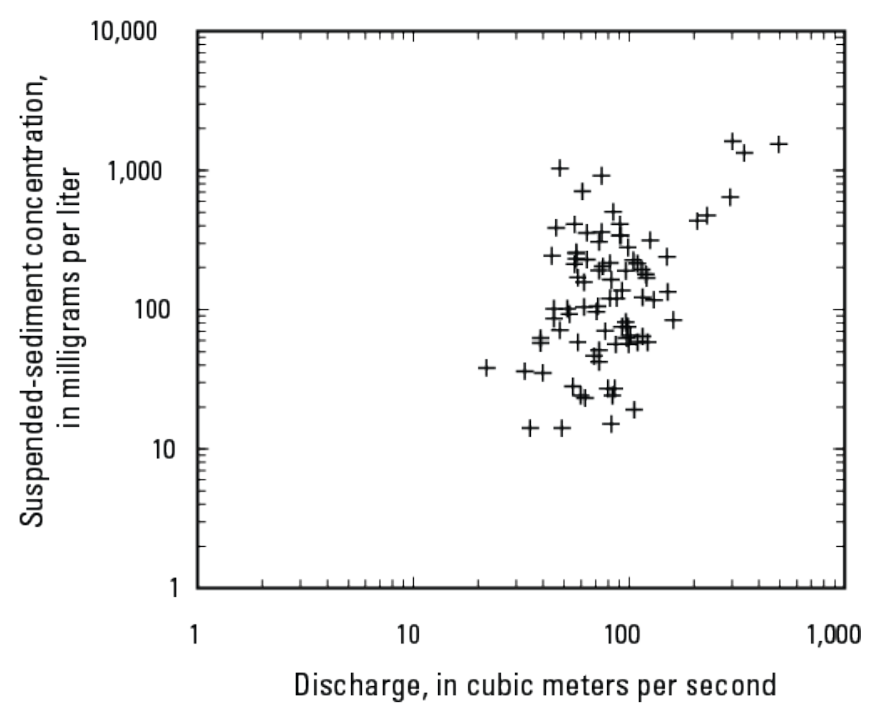

Figure 20. Graph showing suspended-sediment concentration for water years 1978-1994 at U.S. Geological Survey streamflow-gaging station Puyallup River at Puyallup (12101500). 


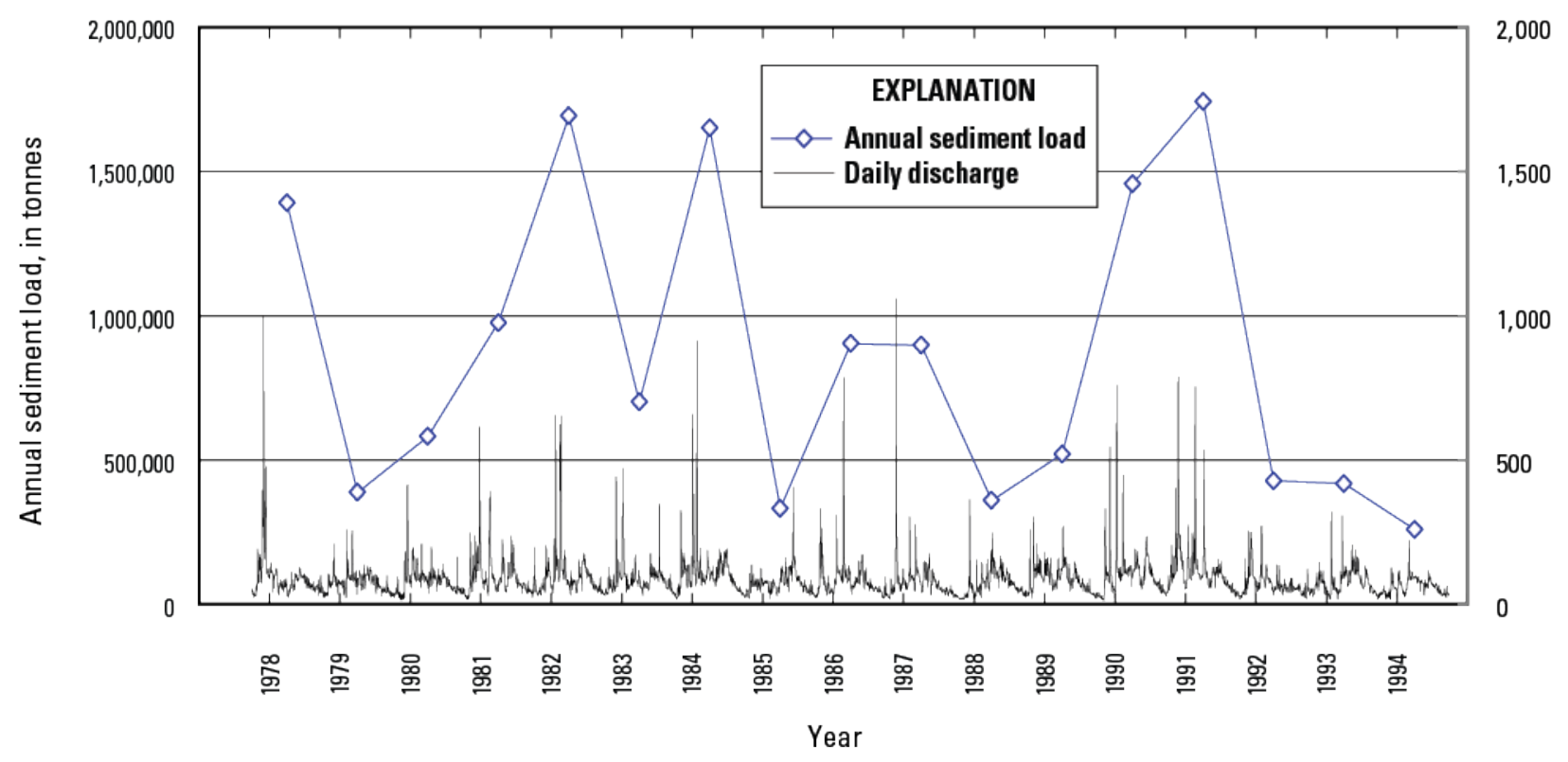

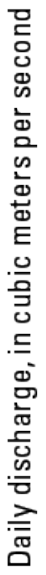

Figure 21. Graph showing annual suspended-sediment load and daily streamflow at U.S. Geological Survey streamflow-gaging station Puyallup River at Puyallup (12101500). 


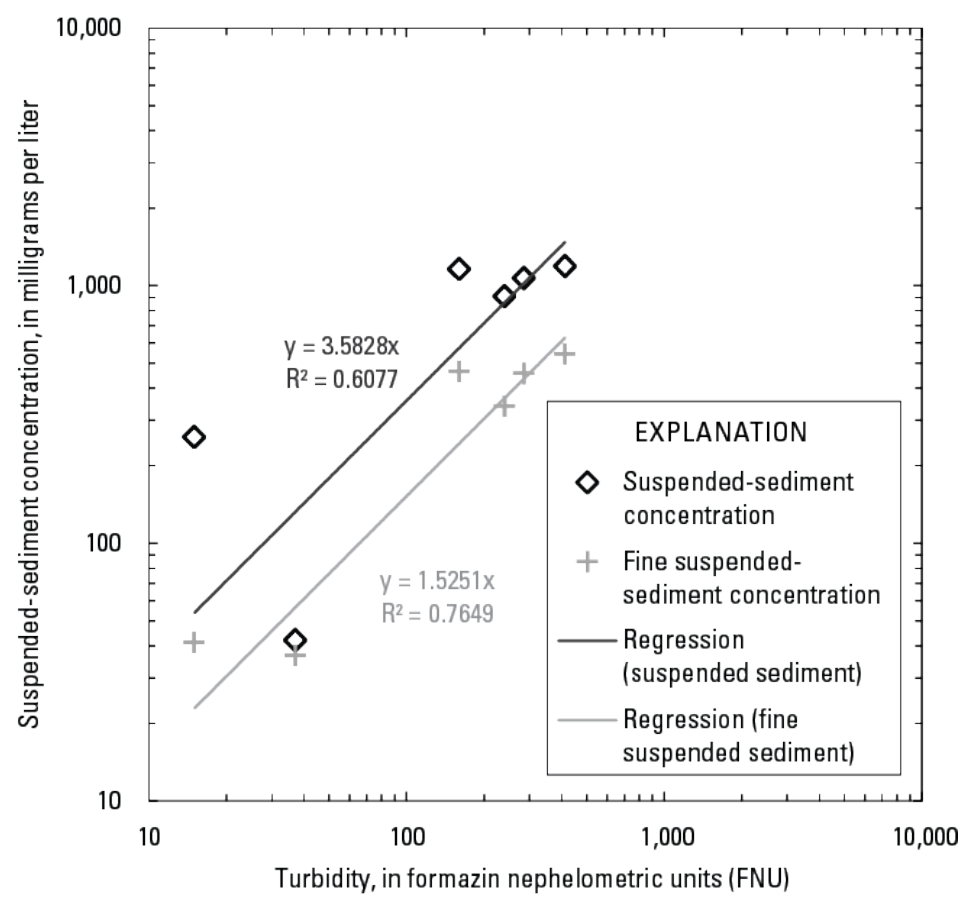

Figure 22. Graph showing regression equations used to estimate suspended-sediment concentration and fine suspended-sediment concentration from turbidity at U.S. Geological Survey streamflow-gaging station White River at R Street near Auburn (12100490).

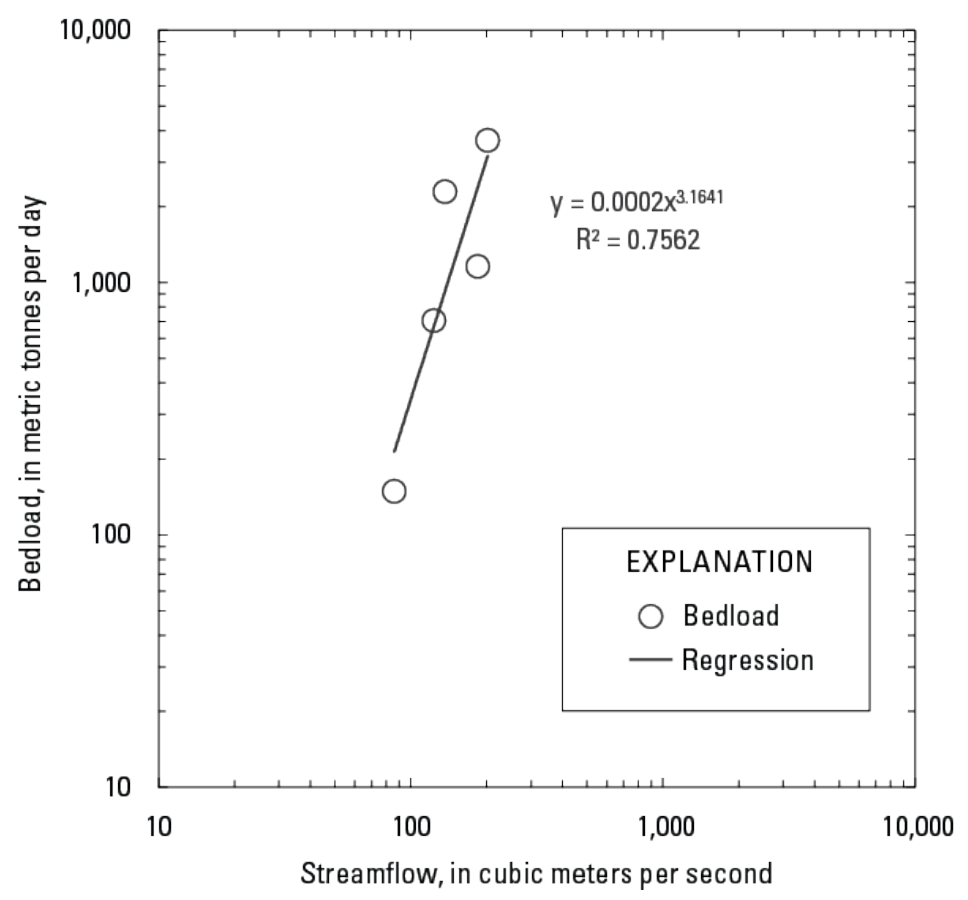

Figure 23. Graph showing regression equation used to estimate bedload from streamflow at U.S. Geological Survey streamflow-gaging station White River at R Street near Auburn (12100490). 


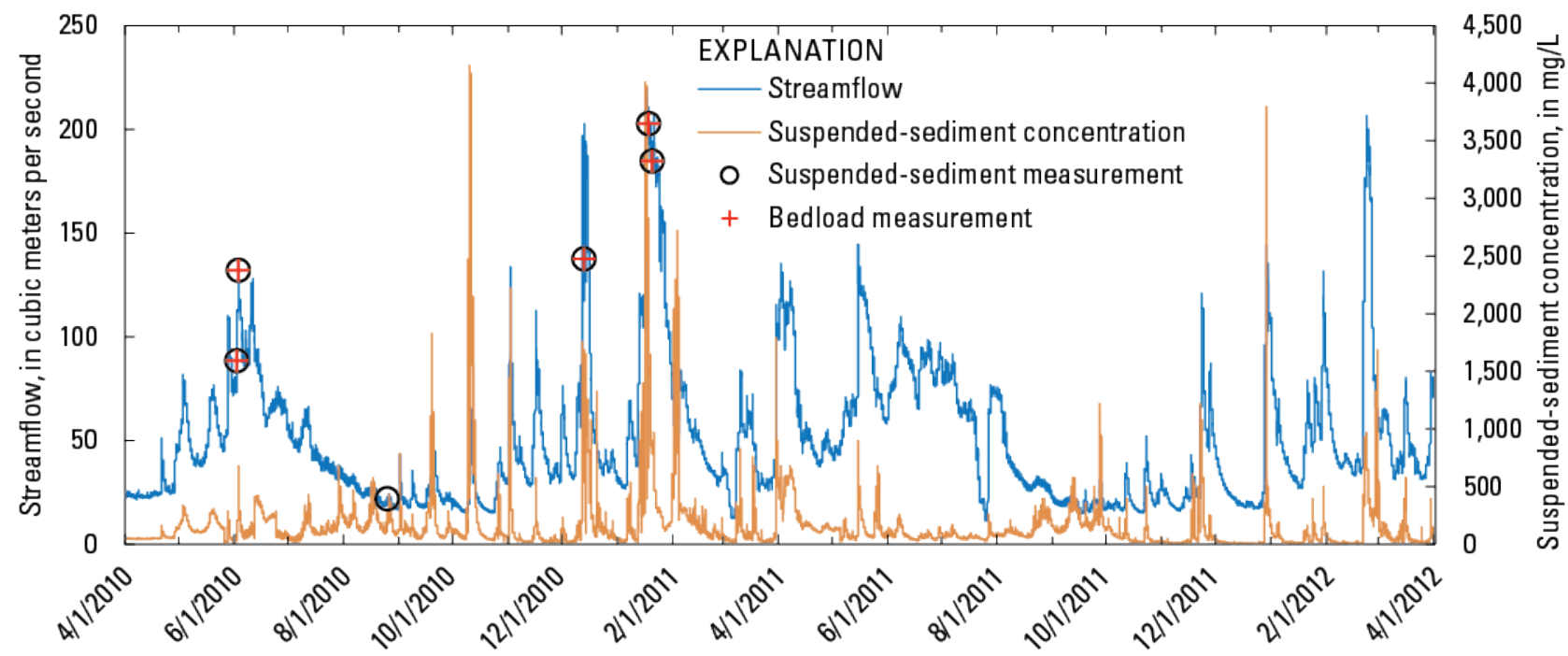

Figure 24. Graph showing time series of streamflow and suspended-sediment concentration at U.S. Geological Survey streamflow-gaging station White River at R Street near Auburn (12100490). The time when suspendedsediment and bedload measurements were made are indicated on the streamflow hydrograph.

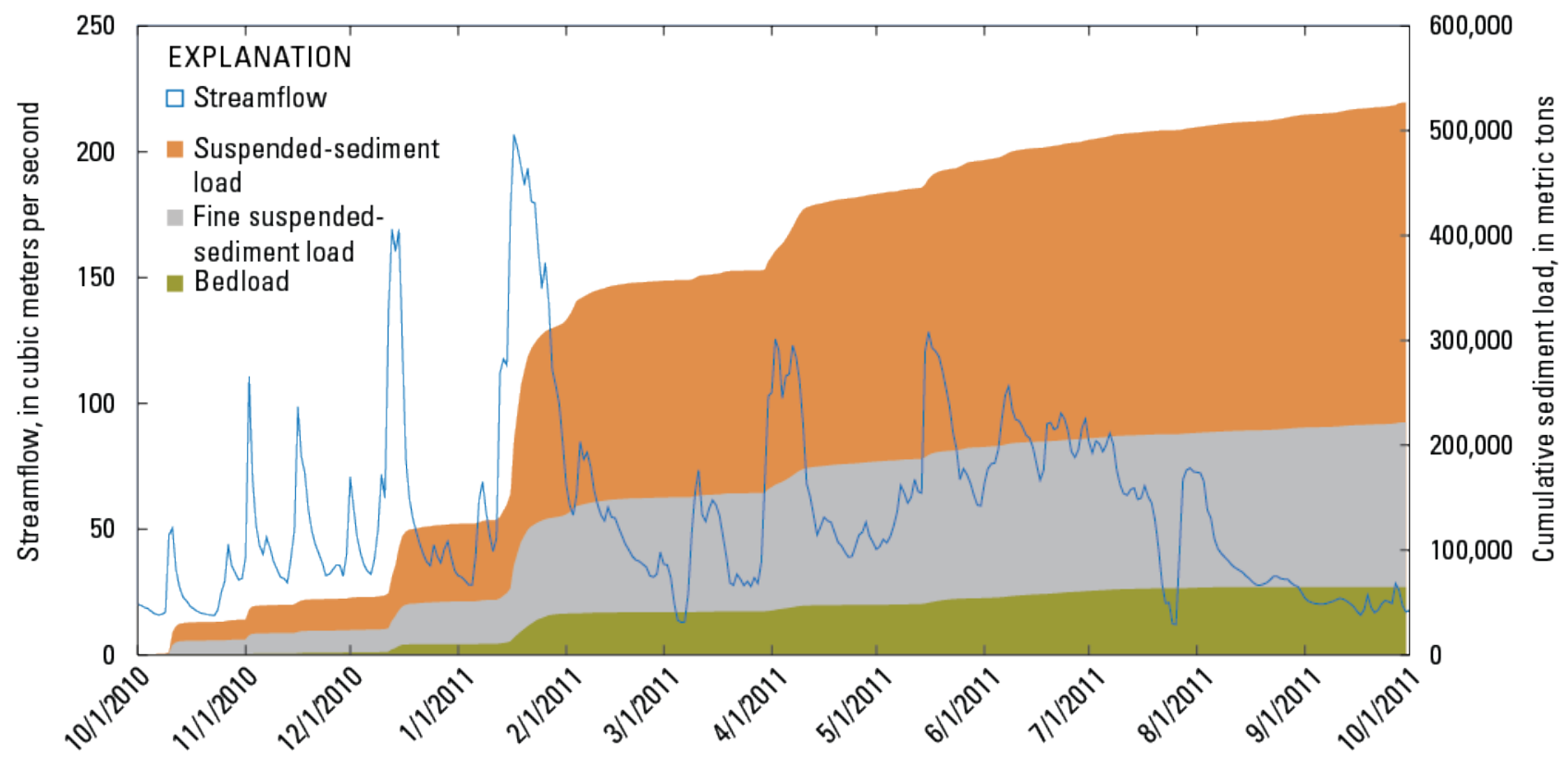

Figure 25. Graph showing time series of streamflow, cumulative suspended-sediment load, cumulative fine suspended-sediment load, and cumulative bedload for water year 2011 at U.S. Geological Survey streamflowgaging station White River at R Street near Auburn (12100490). 


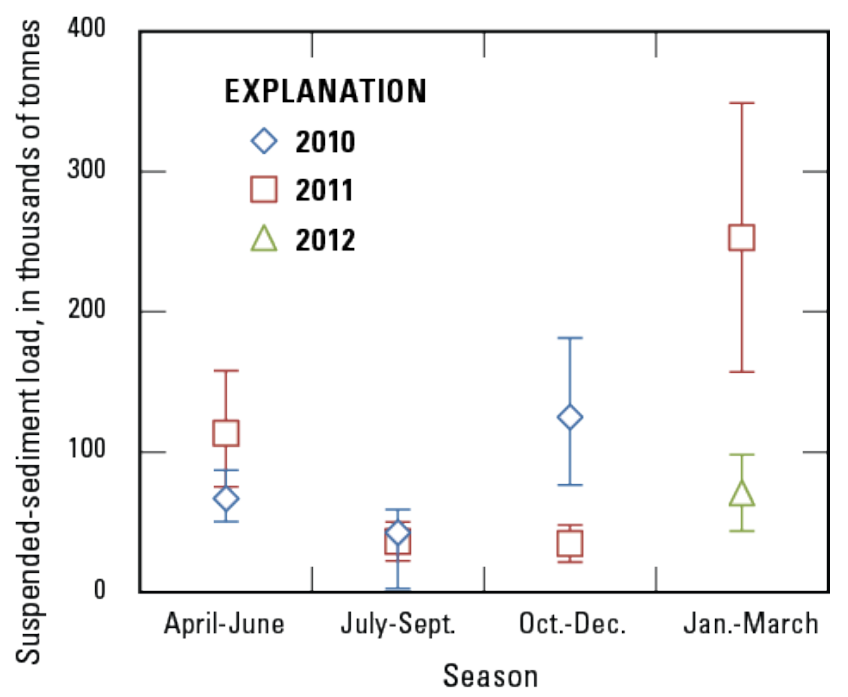

Figure 26. Graph showing suspended-sediment loads for 3-month periods at the U.S. Geological Survey streamflow-gaging station White River at R Street near Auburn (12100490). Error bars represent the 95 percent confidence intervals for the quarterly estimate.

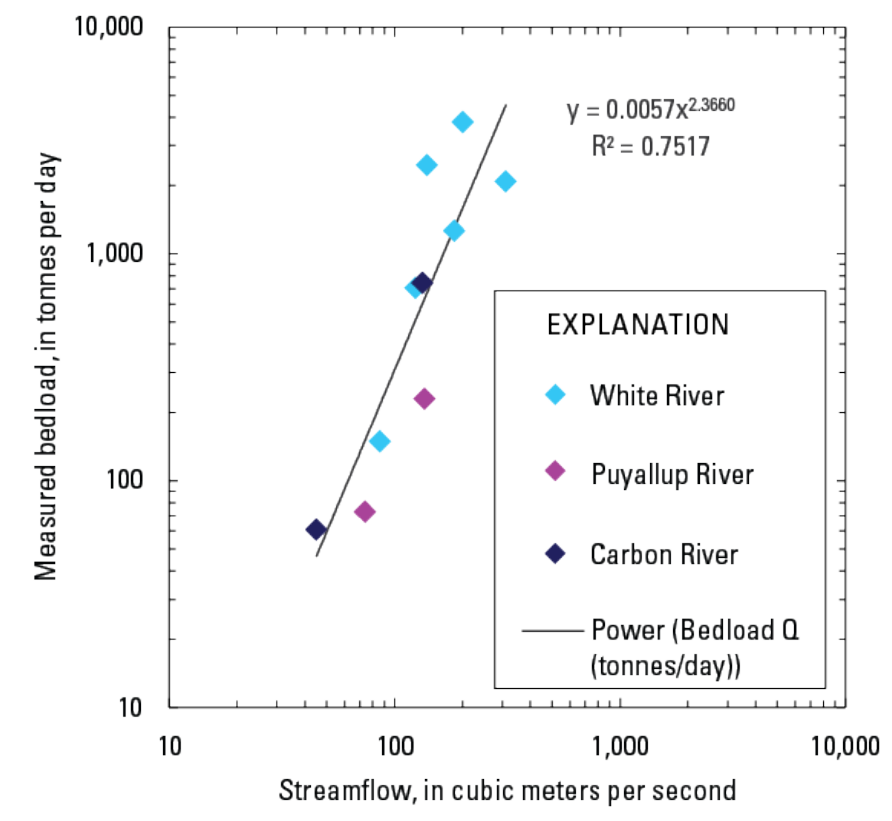

Figure 27. Graph showing bedload measurements from 1986 and 2010-2011 at U.S. Geological Survey streamflow-gaging stations Carbon River near Orting (12094300, referred to as Carbon River at Crocker by Sikonia, 1990), Puyallup River near Orting (12093500), and White River at R Street near Auburn (12100490). 


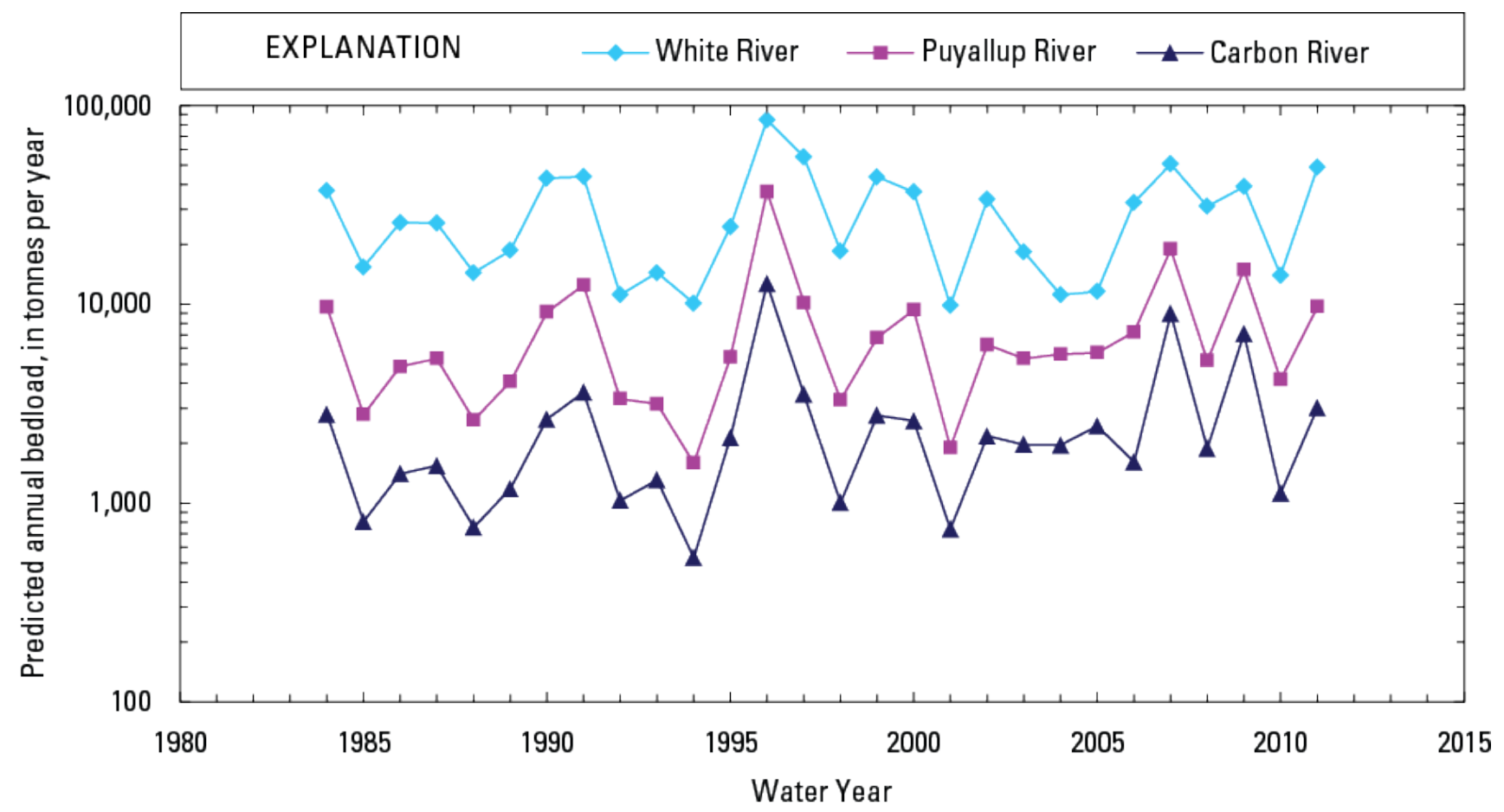

Figure 28. Graph showing estimated annual bedload for water years 1984-2011 at U.S. Geological Survey streamflow-gaging stations Carbon River near Orting (12094300, referred to as the Carbon River at Crocker by Sikonia, 1990), Puyallup River near Orting (12093500), and White River at R Street near Auburn (12100490). 


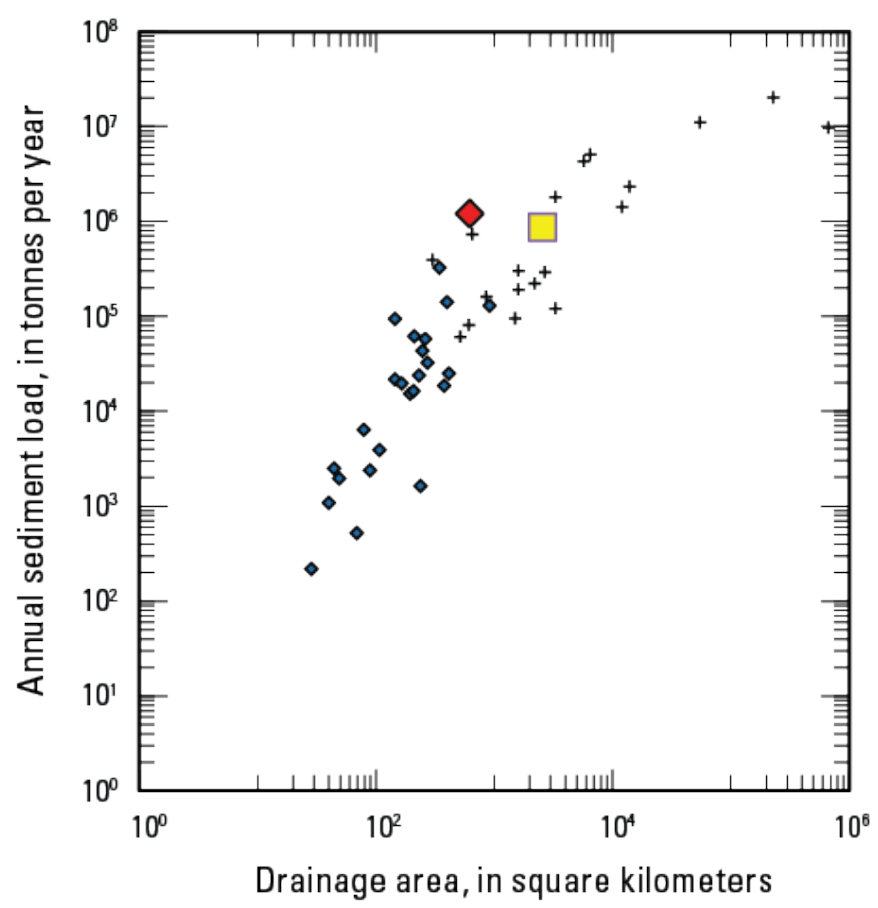

\section{EXPLANATION}

- Rivers in western Washington (Nelson, 1971; 1974)

+ Rivers in the Pacific Northwest (Milliman and Farnsworth, 2011)

$\diamond$ Nisqually River upstream of Alder Lake

$\square$ Puyallup River at Puyallup, WA, 1978 - 1994

Figure 29. Graph showing sediment load values of the Nisqually River flowing into Alder Lake and the lower

Puyallup River compared to sediment-load data reported from other rivers throughout the Pacific Northwest. 

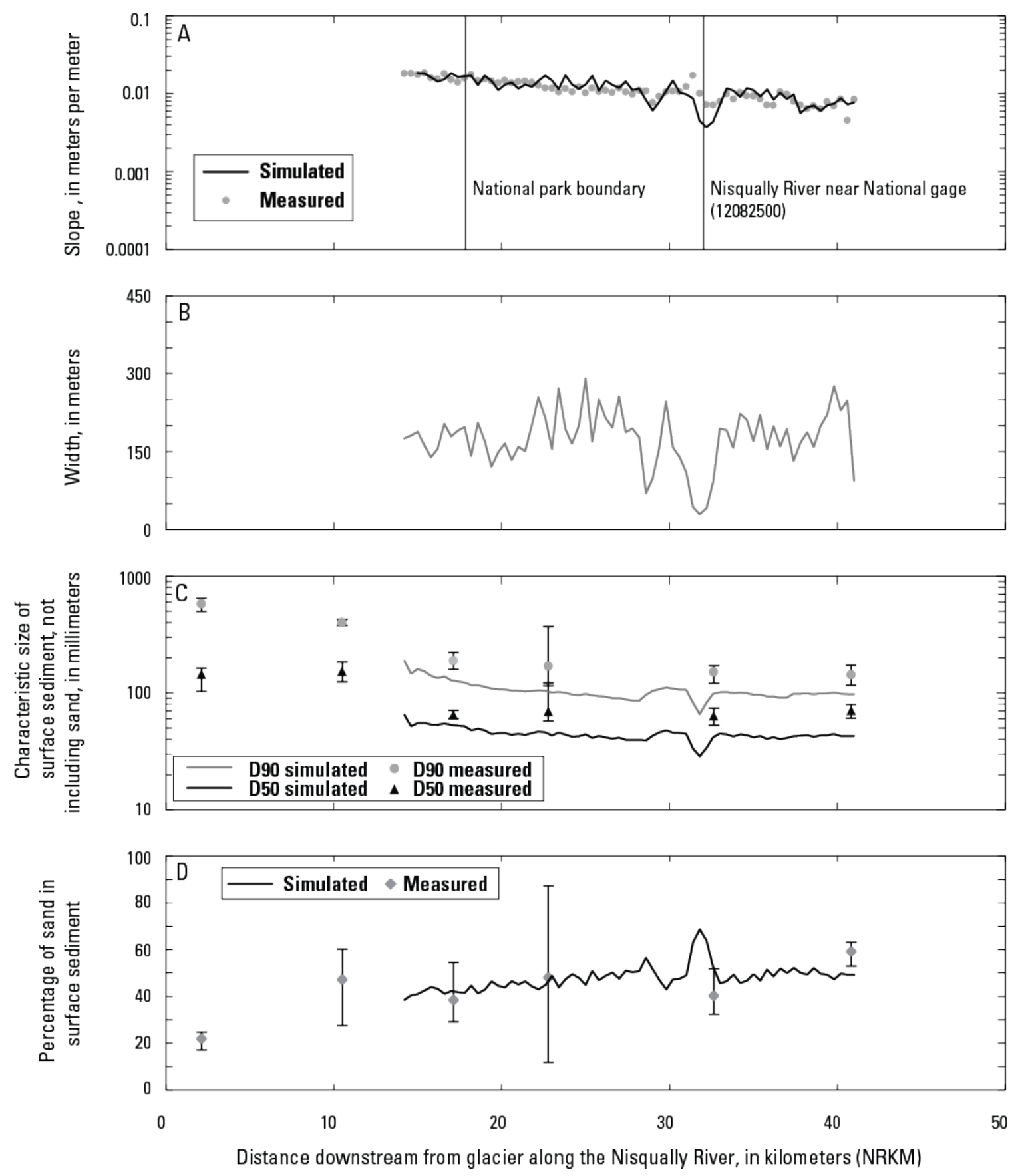

Figure 30. Graph showing geomorphic variables of the Nisqually River: (A) slope, (B) measured active-channel width, (C) D90 and D50 size of bed-surface sediment, and (D) percent sand of bed-surface sediment. Error bars represent one standard deviation of the particle-size distribution. 

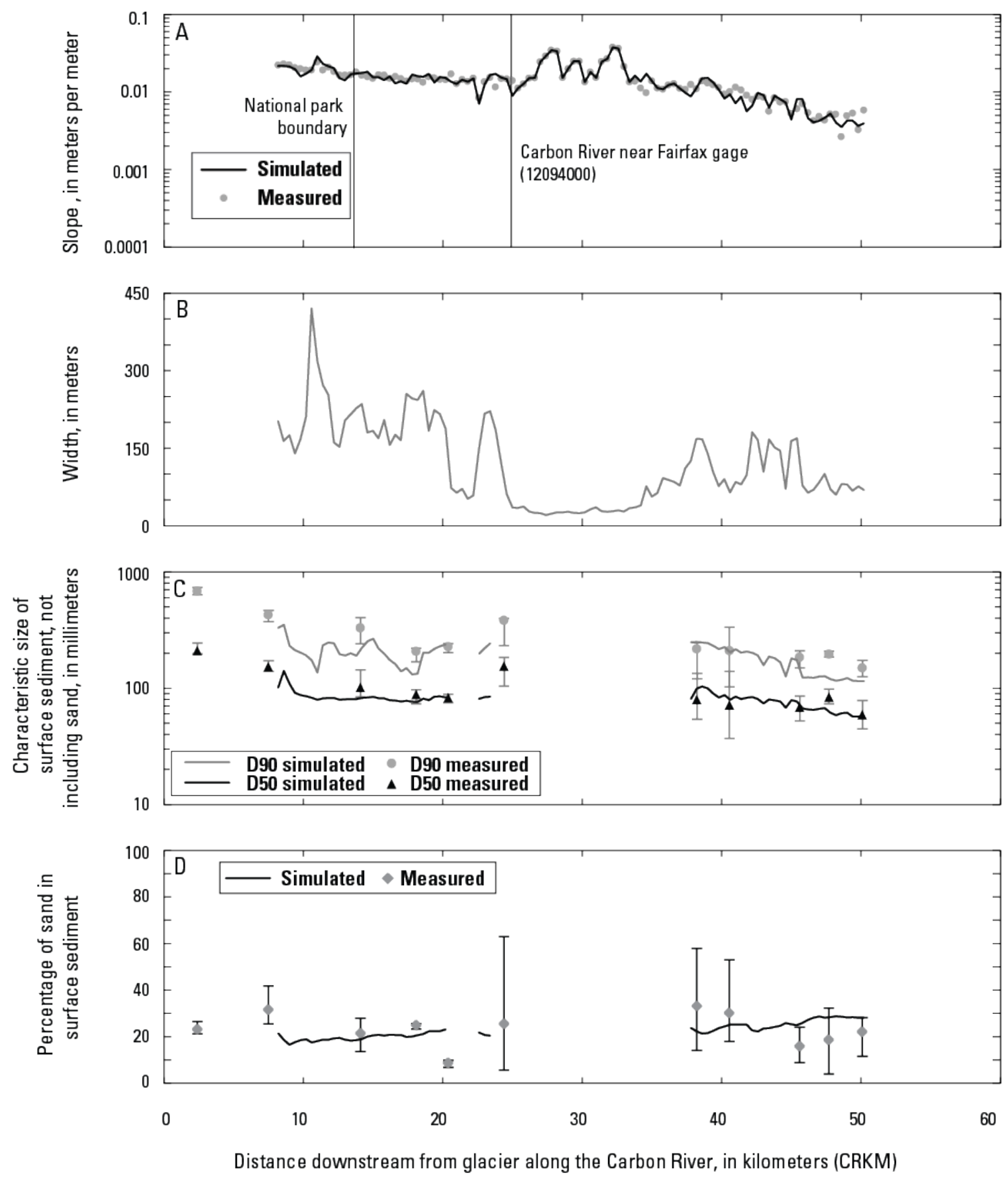

Figure 31. Graph showing geomorphic variables of the Carbon River: (A) slope, (B) measured active-channel width, (C) D90 and D50 size of bed-surface sediment, and (D) percent sand of bed-surface sediment. Error bars represent one standard deviation of the particle-size distribution. 

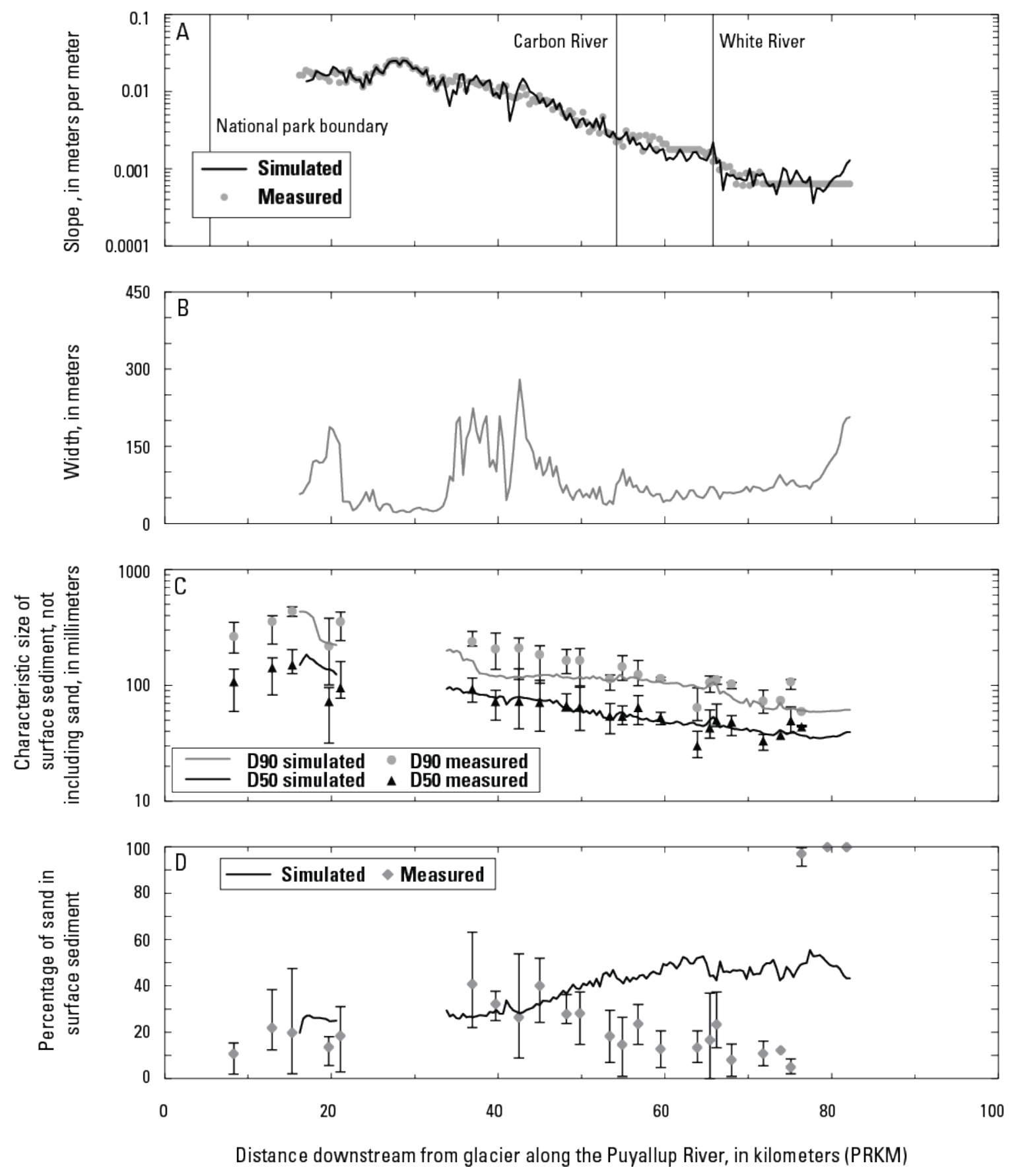

Figure 32. Graph showing geomorphic variables of the Puyallup River: (A) slope, (B) measured active-channel width, (C) D90 and D50 size of bed-surface sediment, and (D) percent sand of bed-surface sediment. Error bars represent one standard deviation of the particle-size distribution. 

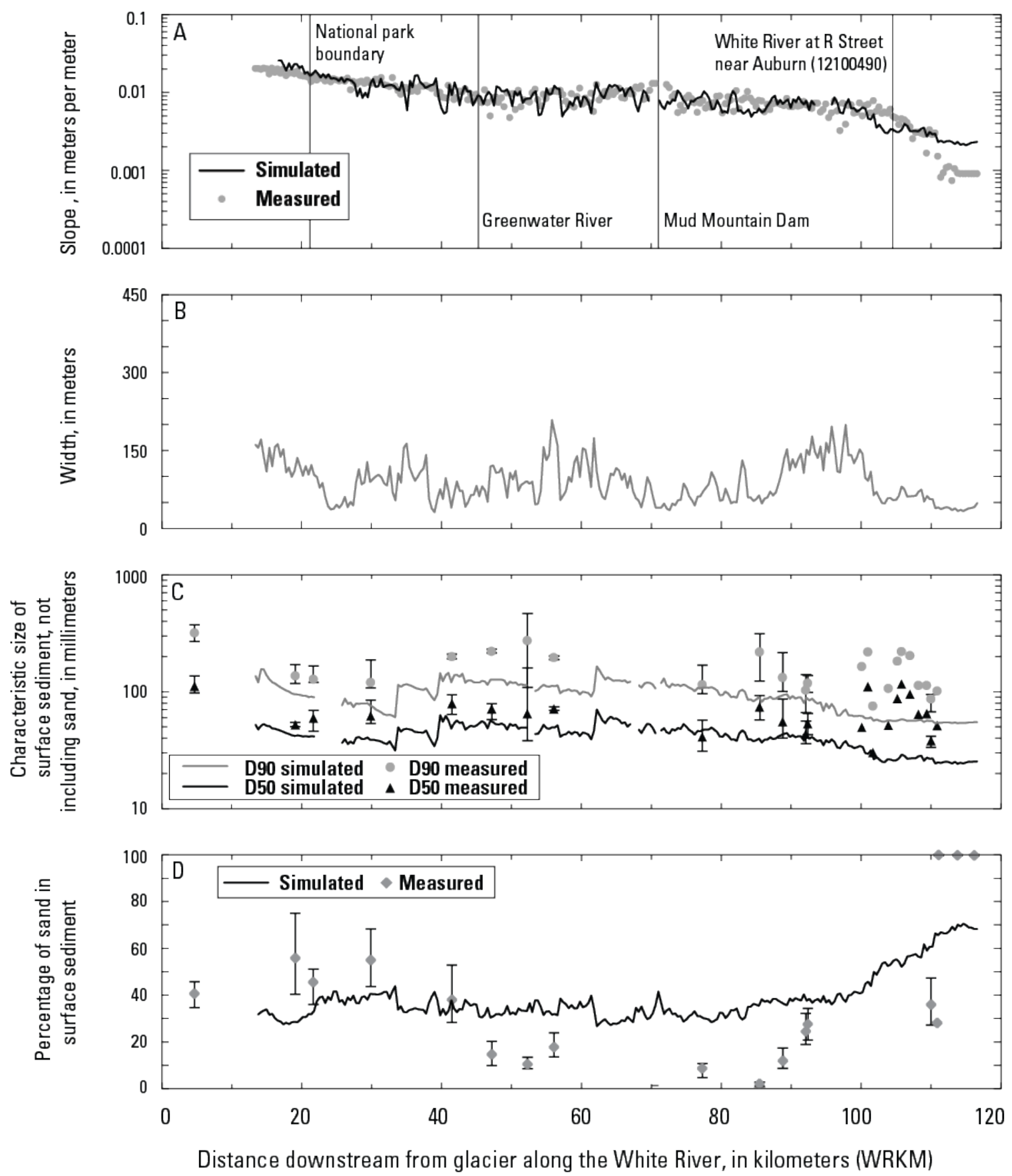

Figure 33. Graph showing geomorphic variables of the White River: (A) slope, (B) measured active-channel width, (C) D90 and D50 size of bed-surface sediment, and (D) percent sand of bed-surface sediment. Error bars represent one standard deviation of the particle-size distribution. 


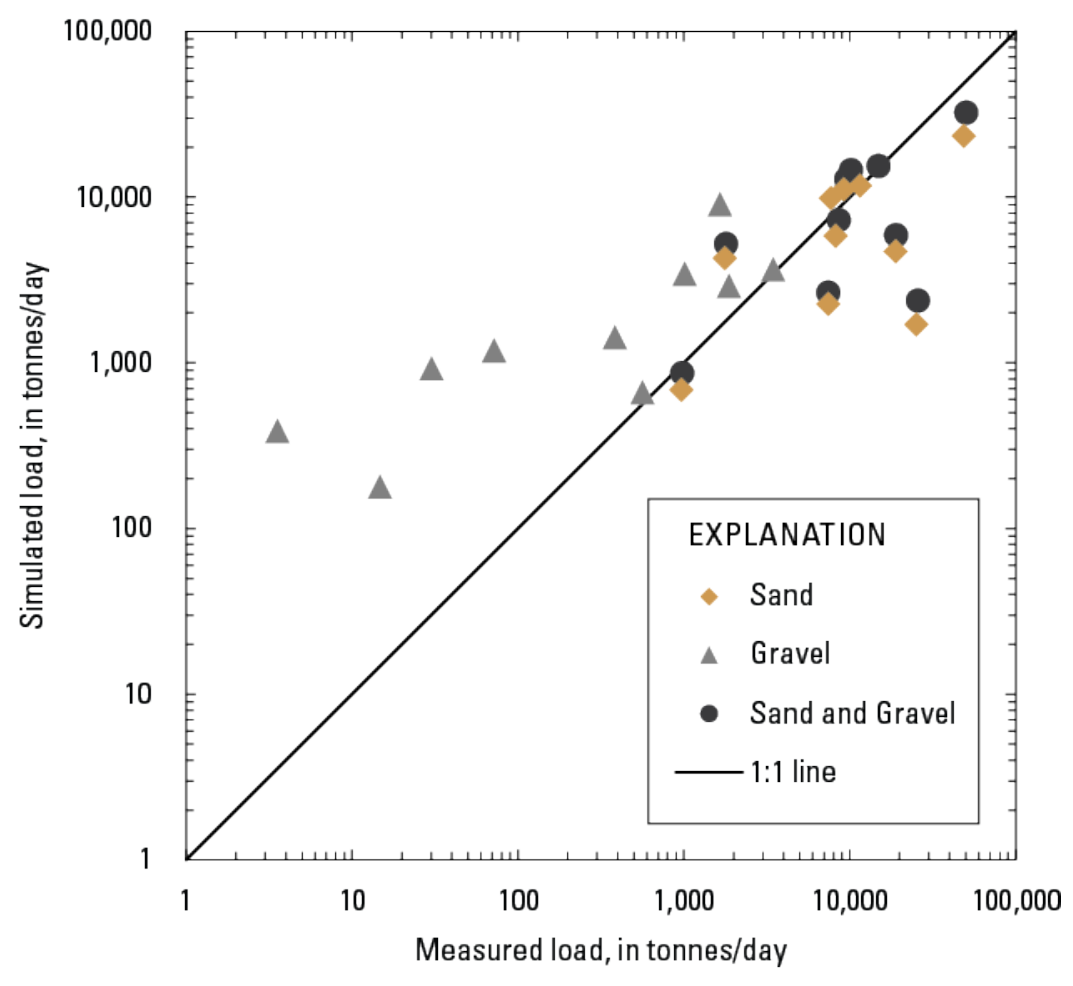

Figure 34. Graph showing comparison of simulated daily sediment loads to measured sediment loads for the Carbon River at State Route 162/Pioneer Way, Puyallup River at Calistoga Street, and White River at R Street. 


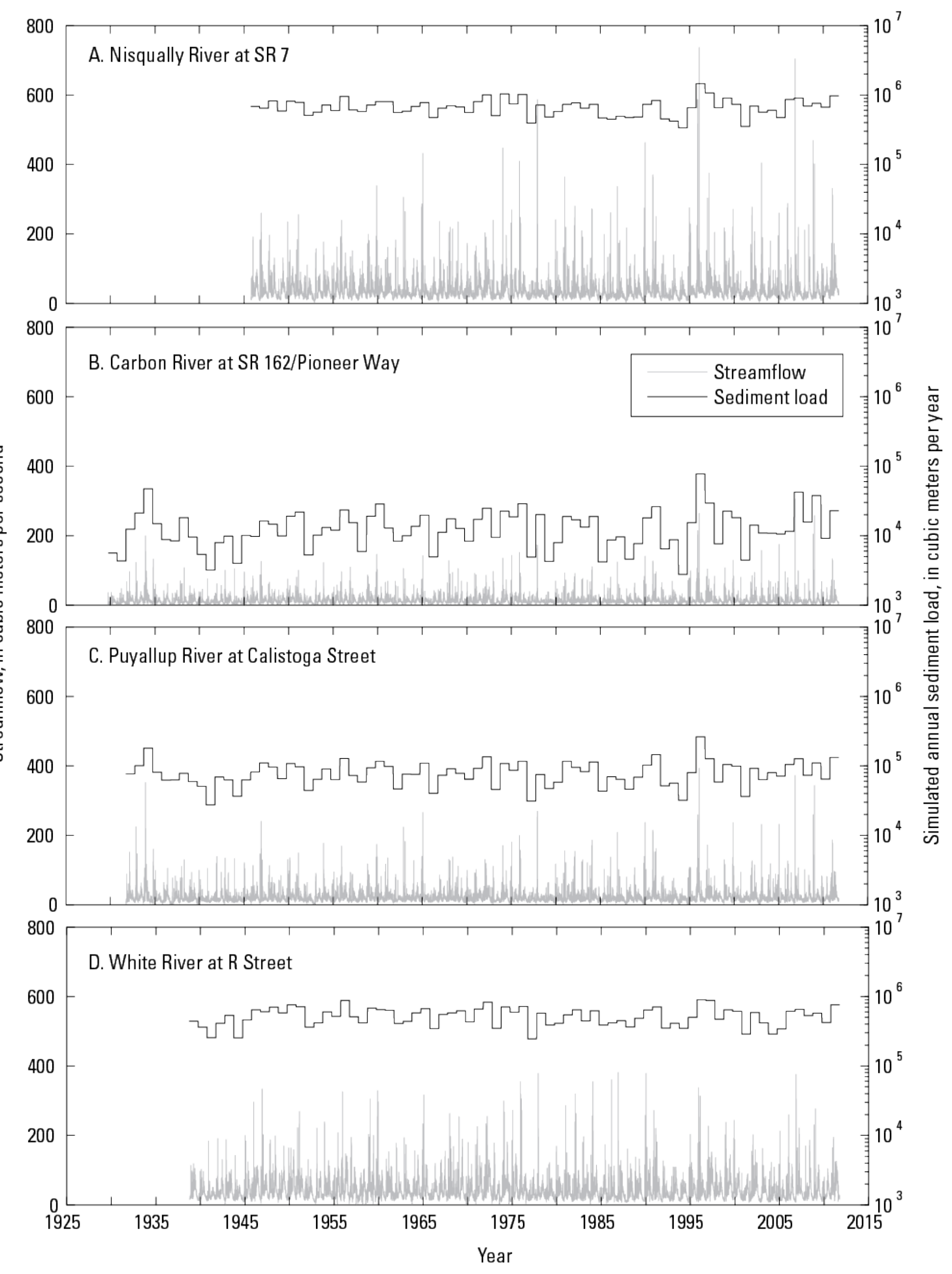

Figure 35. Graph showing daily streamflow and simulated annual bed-material sediment loads for the (A) Nisqually River at State Route 7, (B) Carbon River at State Route 162/Pioneer Way, (C) Puyallup River at Calistoga Street, and (D) White River at R Street. 


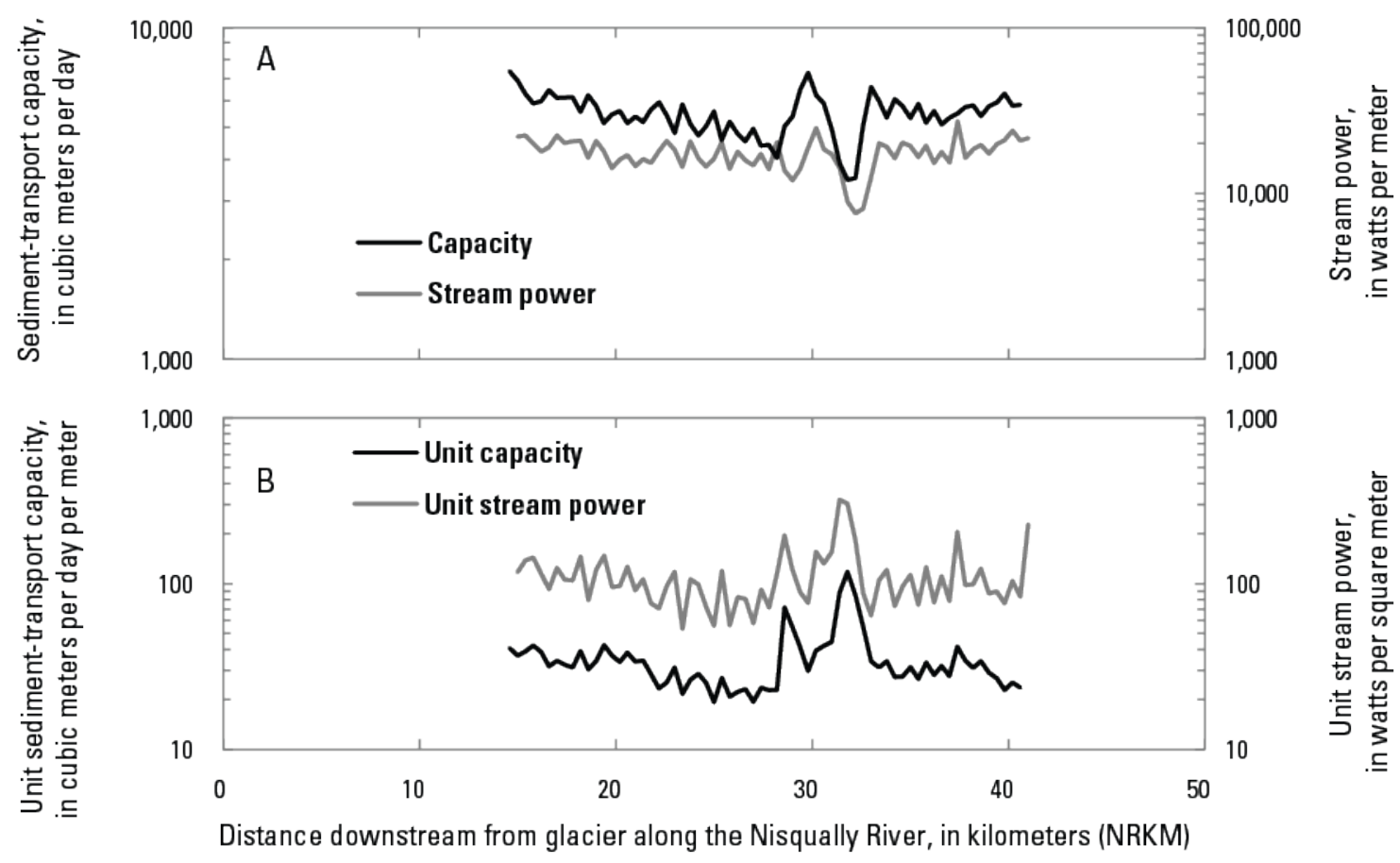

Figure 36. Graph showing capacity of the Nisqually River to transport sediment: (A) bed-material sedimenttransport capacity (after model conditioning) and stream power and (B) unit bed-material sediment-transport capacity (after model conditioning) and unit stream power.

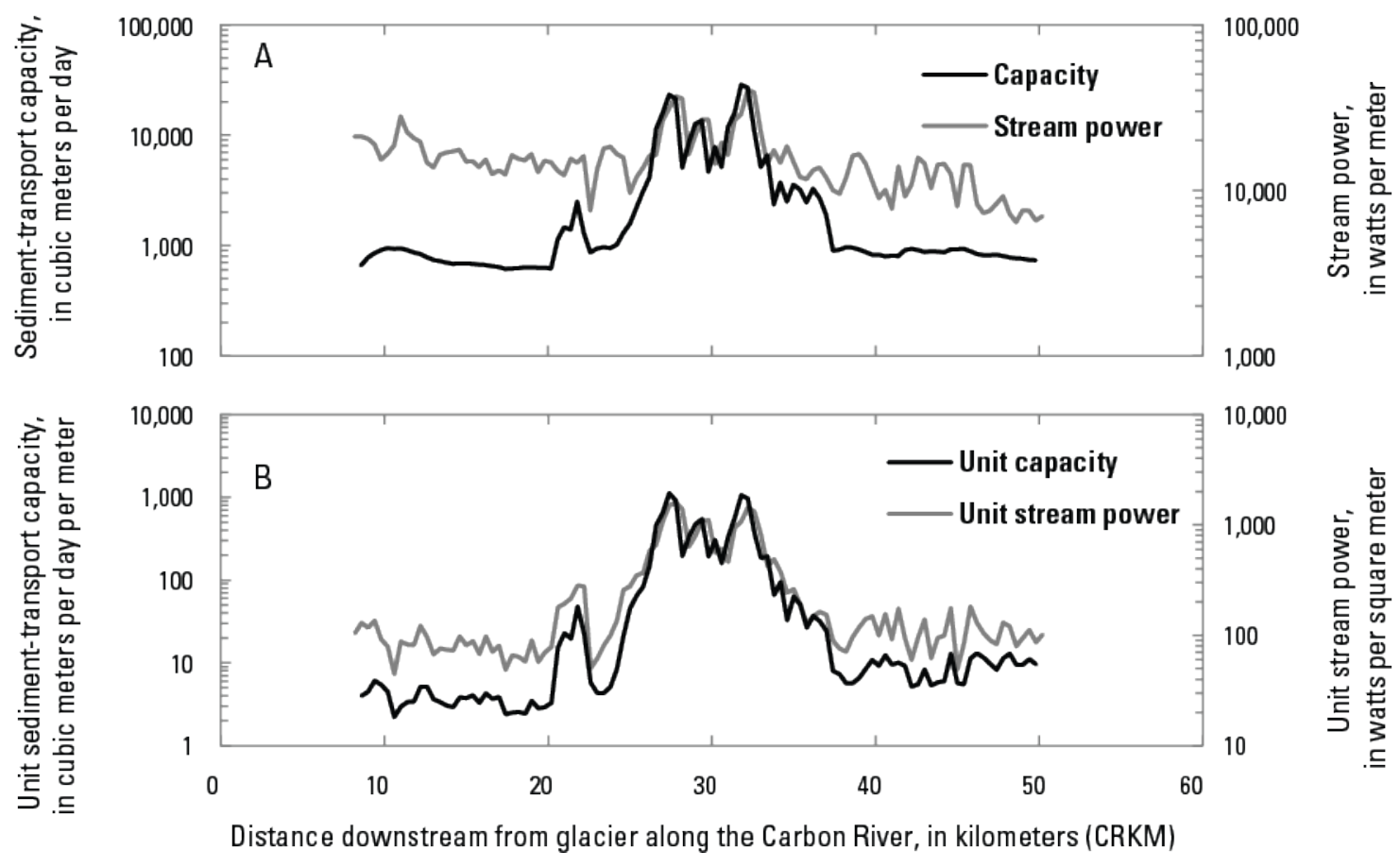

Figure 37. Graph showing capacity of the Carbon River to transport sediment: (A) bed-material sediment-transport capacity (after model conditioning) and stream power and (B) unit bed-material sediment-transport capacity (after model conditioning) and unit stream power. 


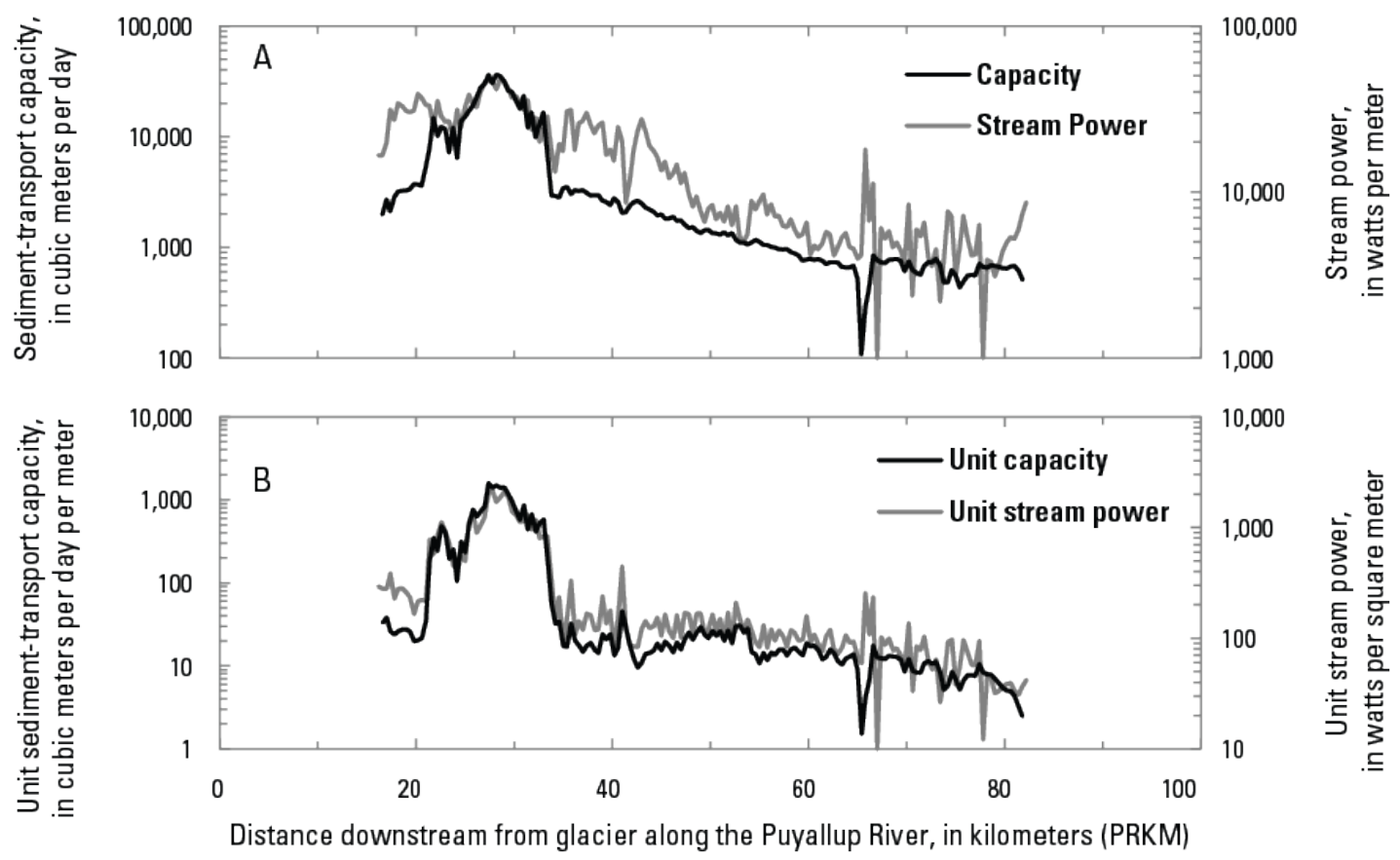

Figure 38. Graph showing capacity of the Puyallup River to transport sediment: (A) bed-material sedimenttransport capacity (after model conditioning) and stream power and (B) unit bed-material sediment-transport capacity (after model conditioning) and unit stream power.
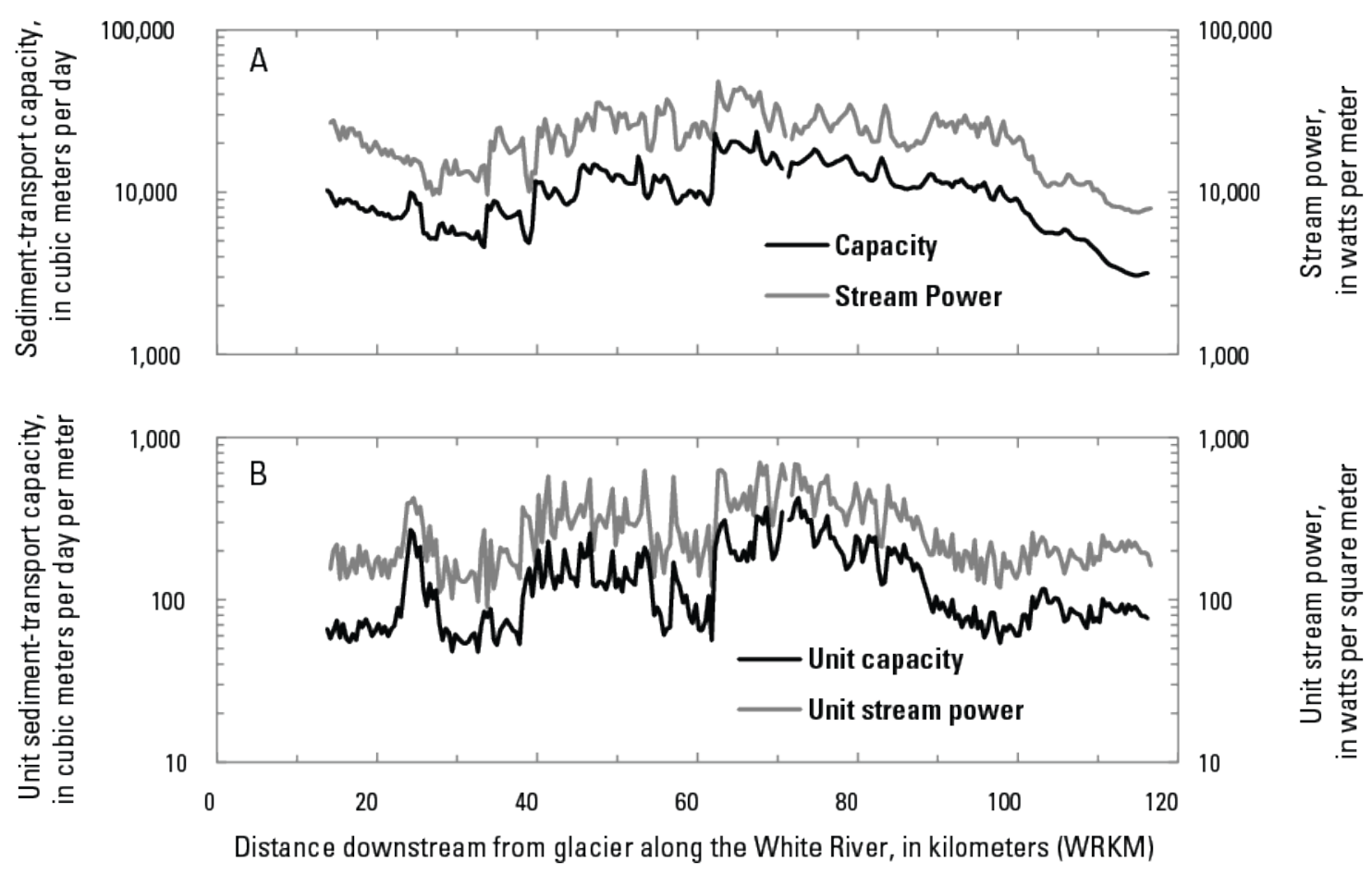

Figure 39. Graph showing capacity of the White River to transport sediment: (A) bed-material sediment-transport capacity (after model conditioning) and stream power and (B) unit bed-material sediment-transport capacity (after model conditioning) and unit stream power. 


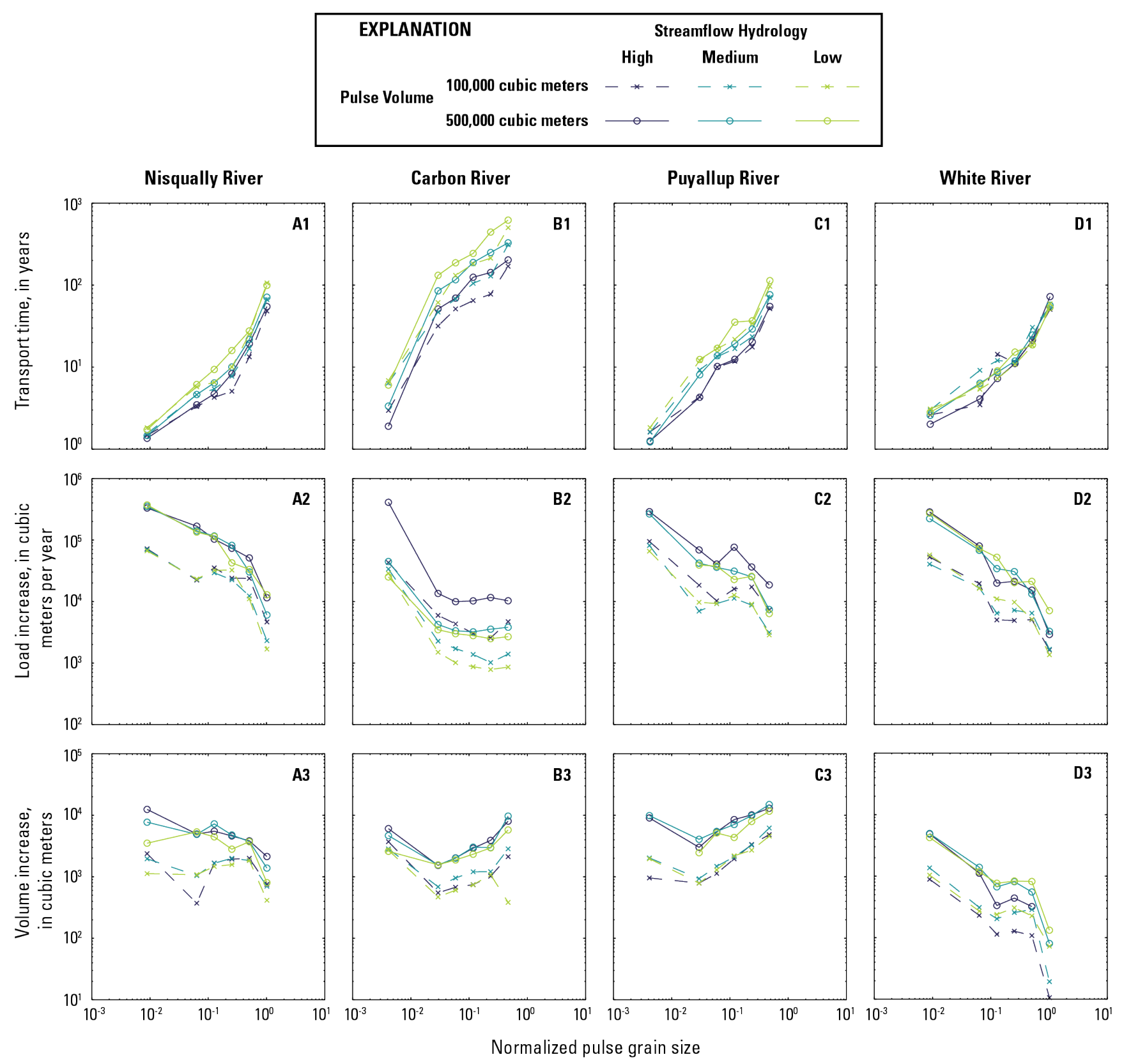

Figure 40. Graph showing effect of pulse grain size, pulse volume, and streamflow on the characteristic transport time (A1-D1), sediment load (A2-D2), and bed volume (A3-D3) for the Nisqually (A1-A3), Carbon (B1-B3), Puyallup (C1-C3), and White Rivers (D1-D3). 

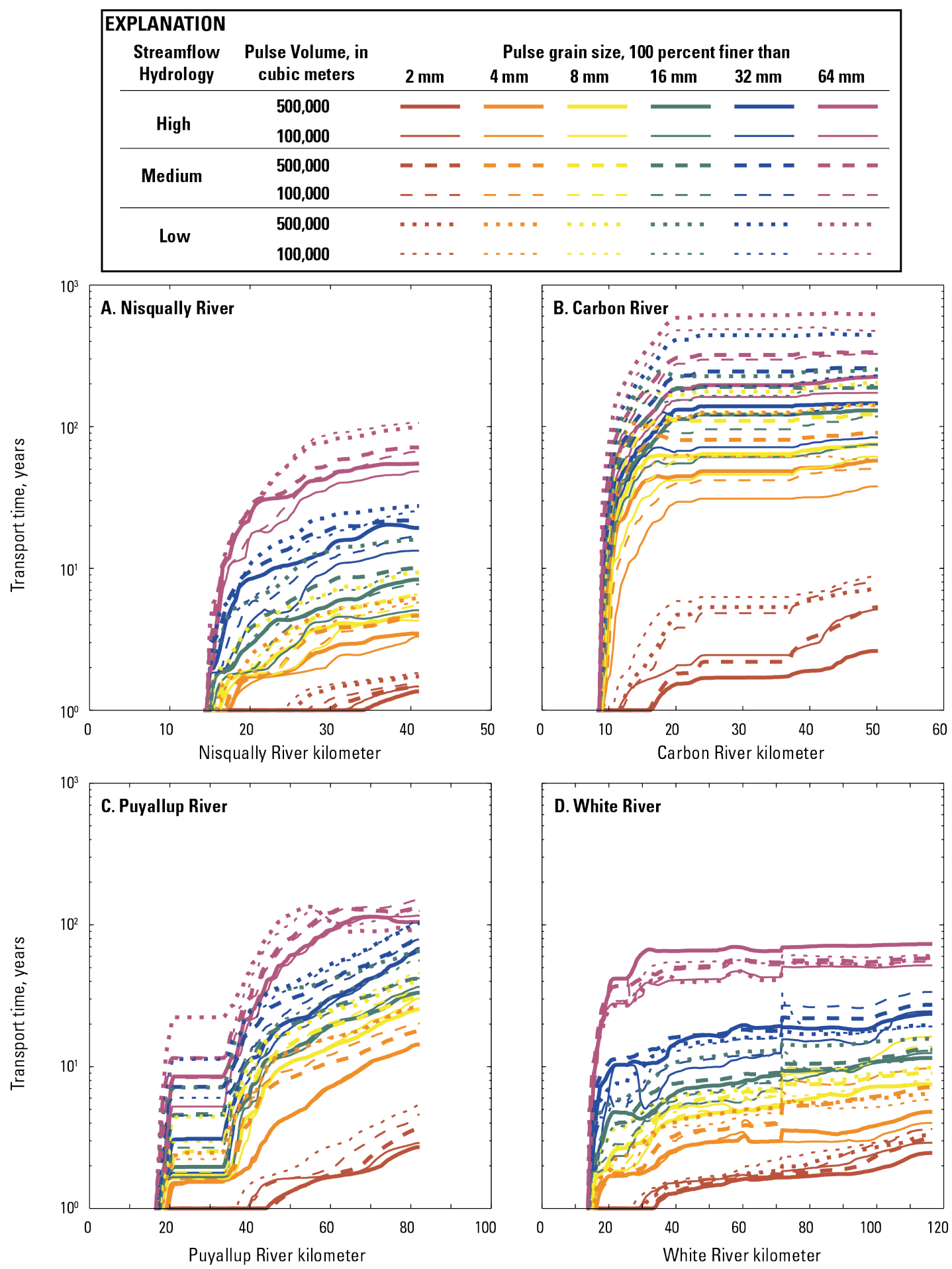

Figure 41. Graph showing characteristic transport time for sediment pulses to arrive downstream for different pulse grain size, pulse volume, and streamflow for the (A) Nisqually, (B) Carbon, (C) Puyallup, and (D) White Rivers. 

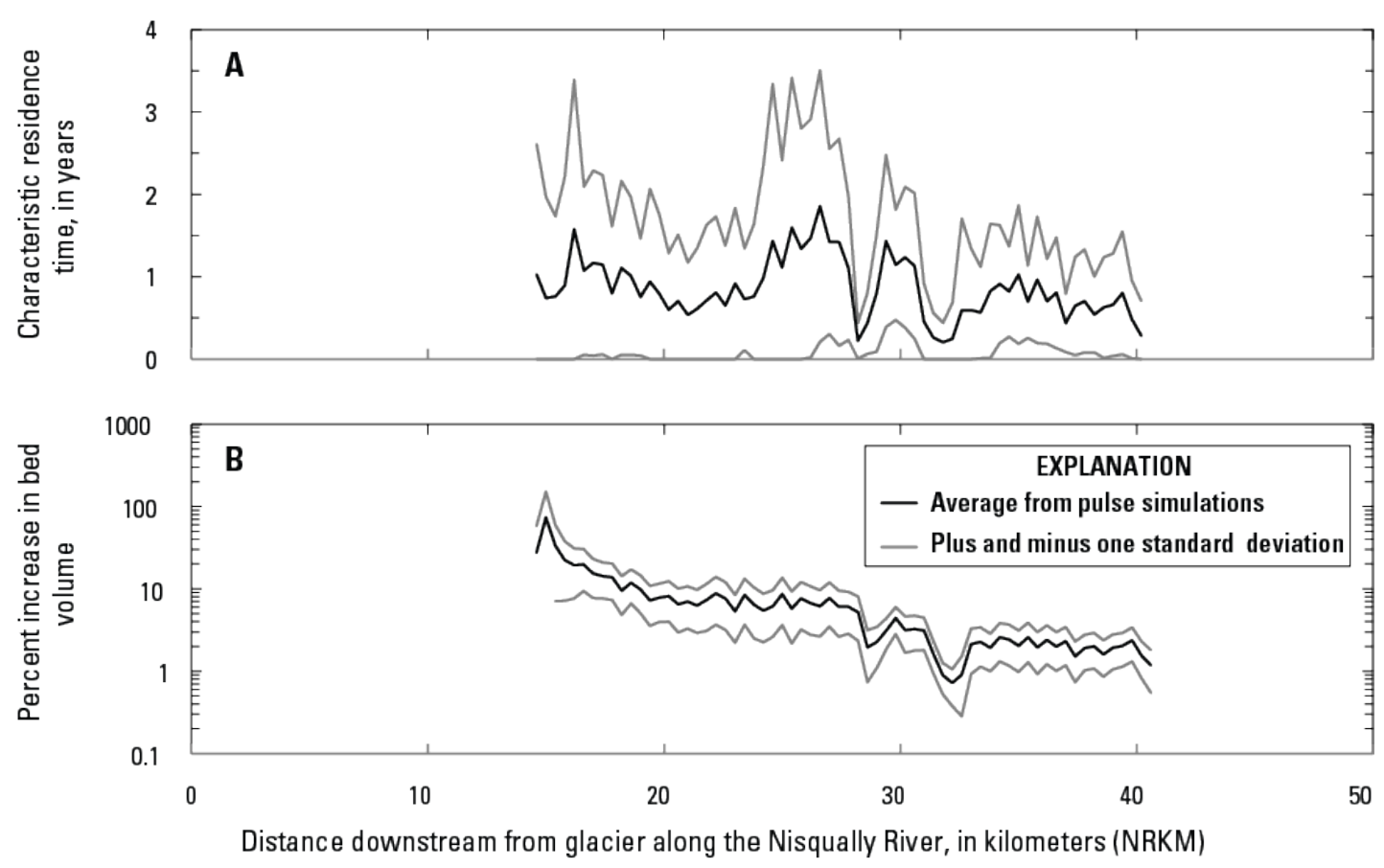

Figure 42. Graph showing Nisqually River response to sediment pulse input for (A) characteristic residence time for D50 sediment to move through each 400-m node and (B) the maximum increase in bed volume as a percentage of input pulse volume.
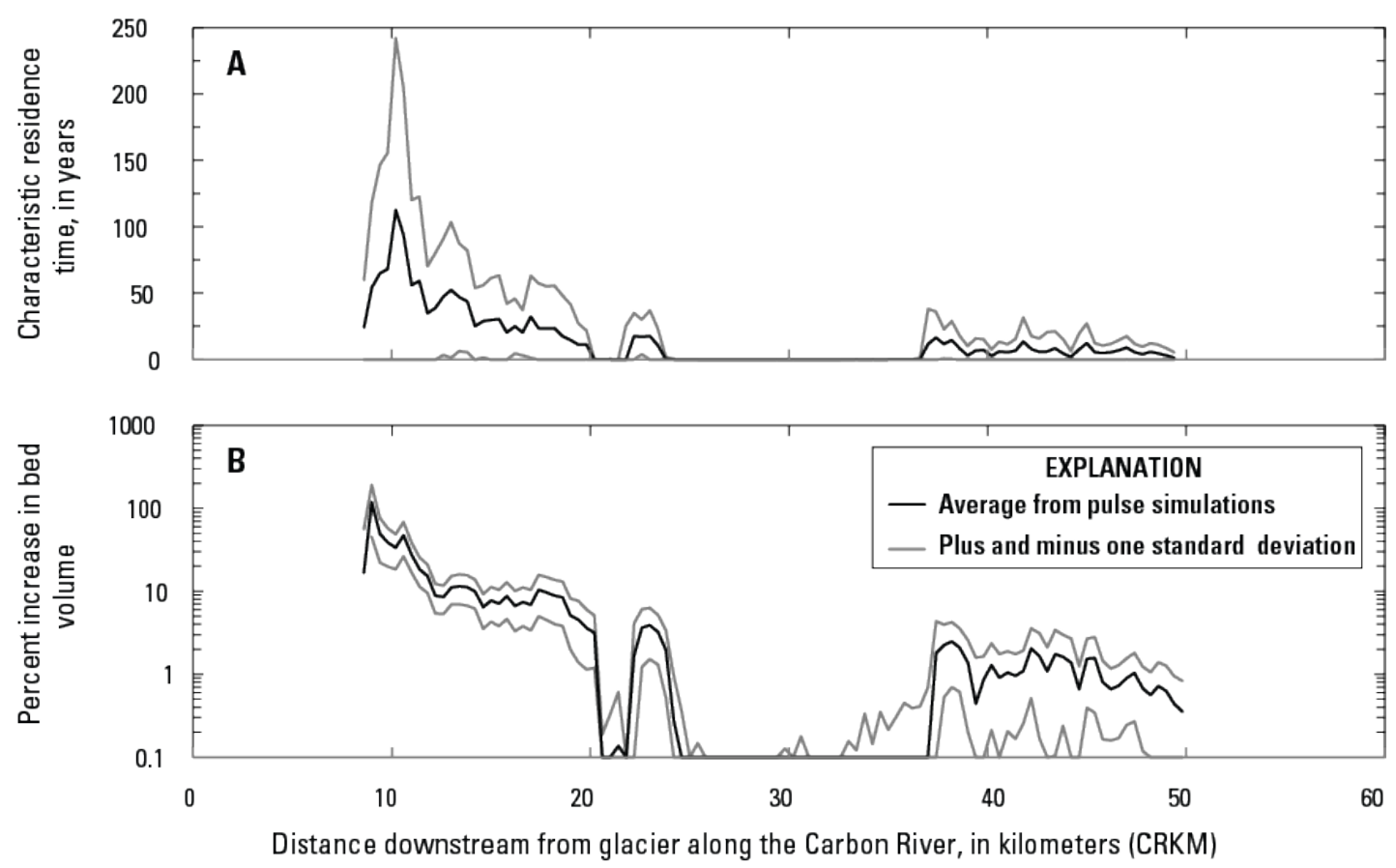

Figure 43. Graph showing Carbon River response to sediment pulse input for (A) characteristic residence time for D50 sediment to move through each 400-m node and (B) the maximum increase in bed volume as a percentage of input pulse volume. 

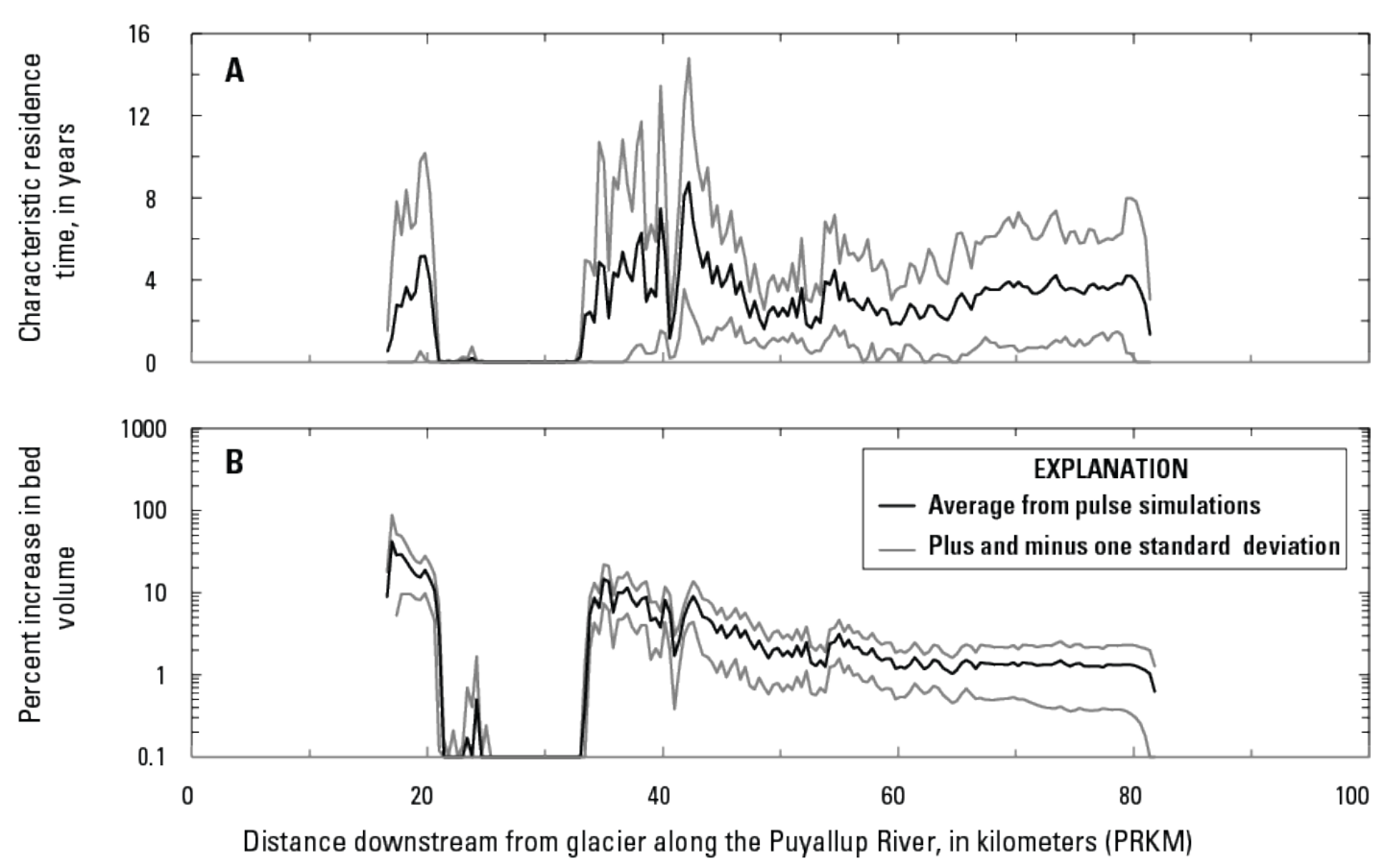

Figure 44. Graph showing Puyallup River response to sediment pulse input for $(A)$ characteristic residence time for D50 sediment to move through each 400-m node and (B) the maximum increase in bed volume as a percentage of input pulse volume.
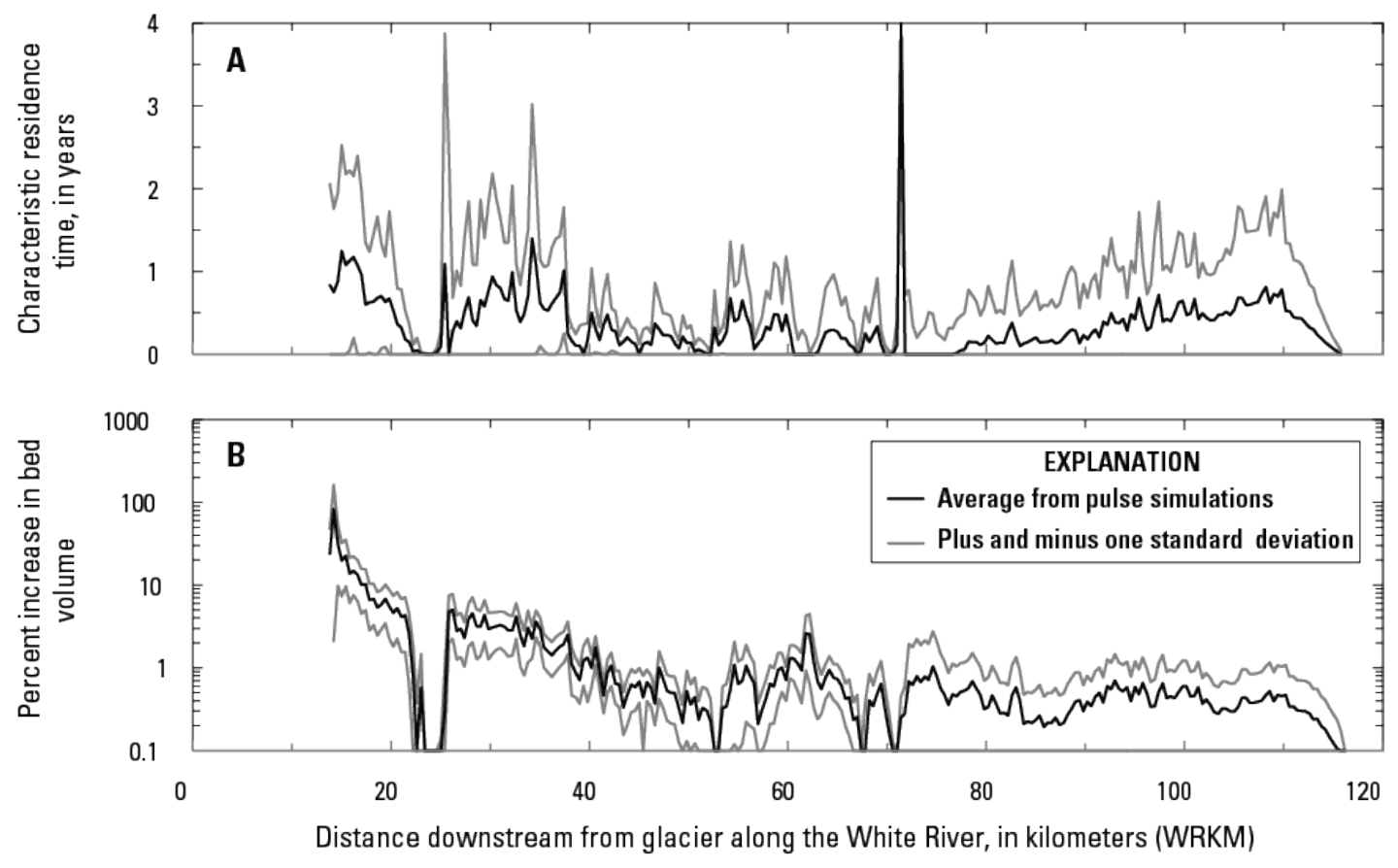

Figure 45. Graph showing White River response to sediment pulse input for $(A)$ characteristic residence time for D50 sediment to move through each 400-m node and (B) the maximum increase in bed volume as a percentage of input pulse volume. 


\section{EXPLANATION}

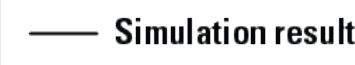

A. 25-year baseline condition

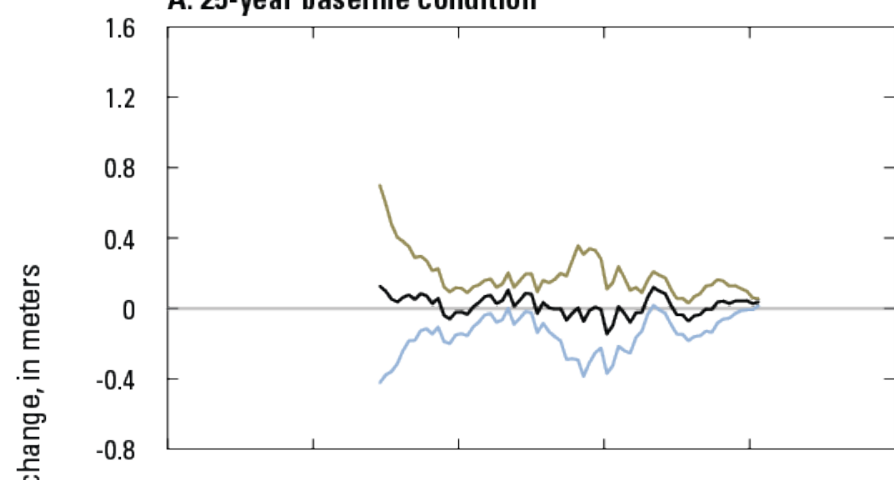

C. 50-year baseline condition

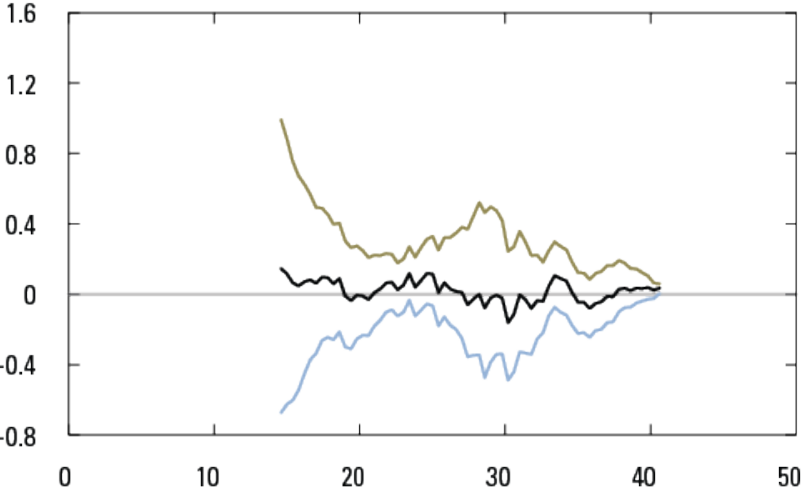

B. 25-year future condition

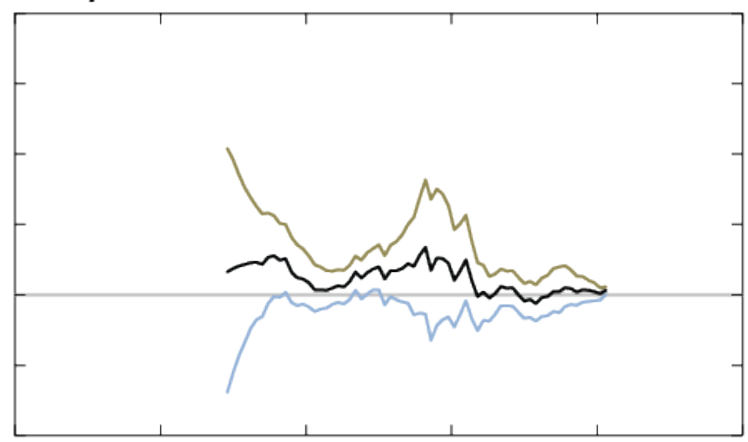

D. 50-year future condition

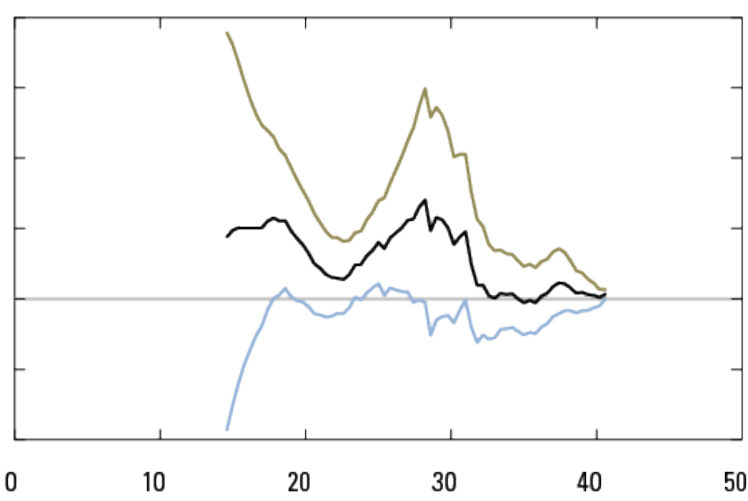

Nisqually River kilometer

Figure 46. Graph showing potential future bed-elevation change for the Nisqually River after 25 years for (A) a baseline condition and (B) a future condition; and after 50 years for $(C)$ a baseline condition and $(D)$ a future condition. 


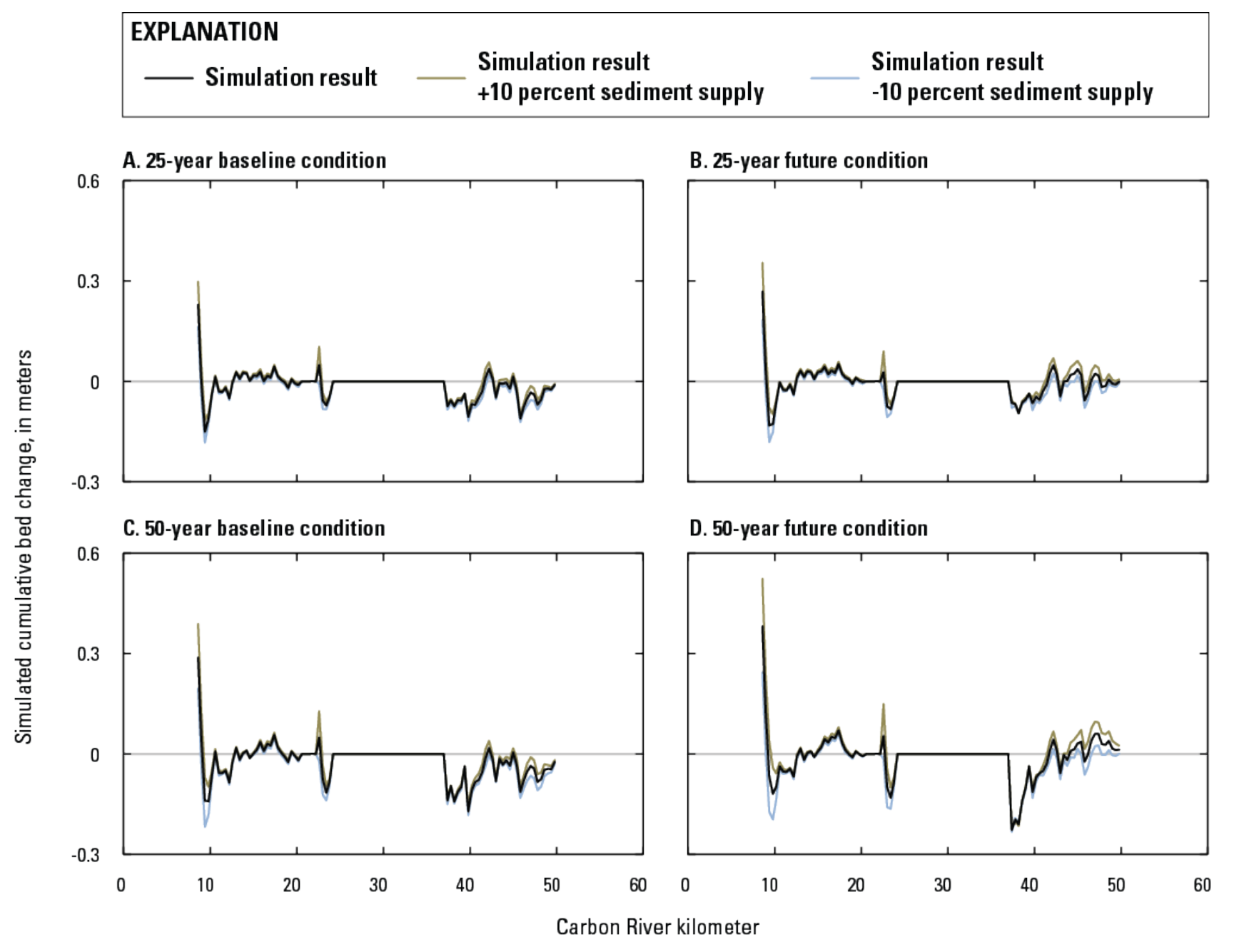

Figure 47. Graph showing potential future bed-elevation change for the Carbon River after 25 years for (A) a baseline condition and (B) a future condition; and after 50 years for (C) a baseline condition and (D) a future condition. 


\section{EXPLANATION}

\section{- Simulation result}

Simulation result +10 percent sediment supply
Simulation result -10 percent sediment supply

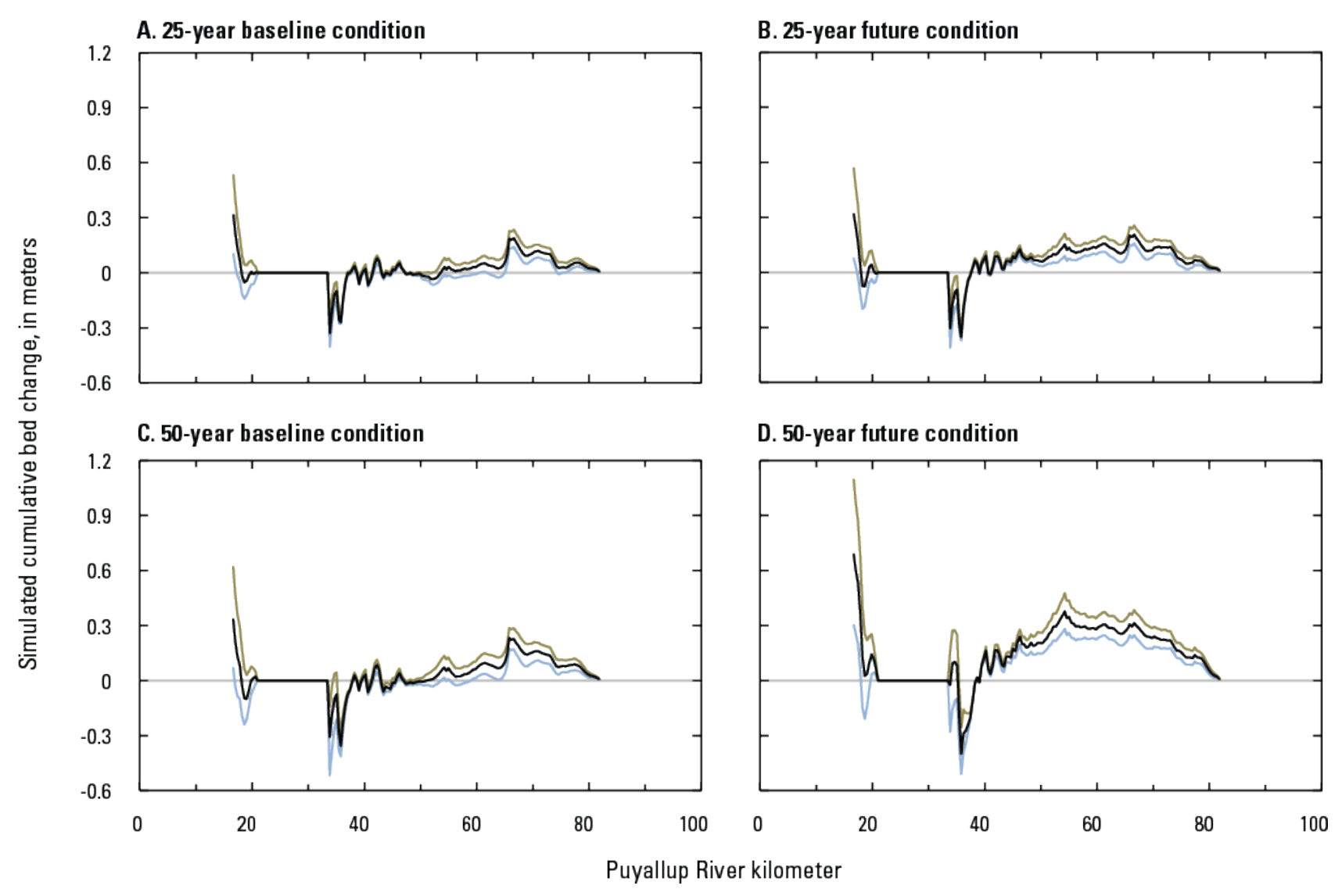

Figure 48. Graph showing potential future bed-elevation change for the Puyallup River after 25 years for (A) a baseline condition and (B) a future condition; and after 50 years for (C) a baseline condition and (D) a future condition. 


\section{EXPLANATION}

- Simulation result

Simulation result

Simulation result +10 percent sediment supply -10 percent sediment supply

A. 25-year baseline condition

要

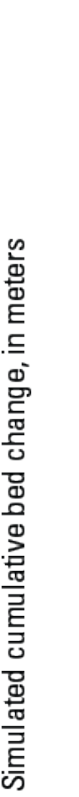

3.2

2.4

1.6

0.8

0

$-8$

$-1.6$

$-2.4$

\section{50-year baseline condition}

4
3.2
2.4
1.6
0.8
0

-

$-2.4$

0
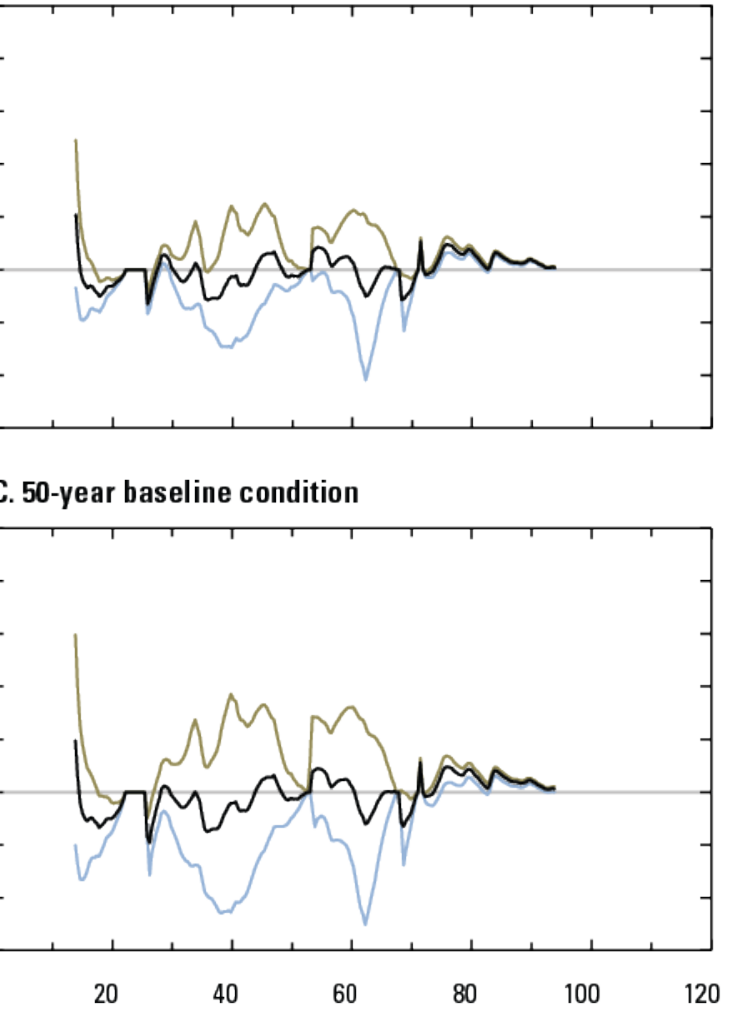

B. 25-year future condition

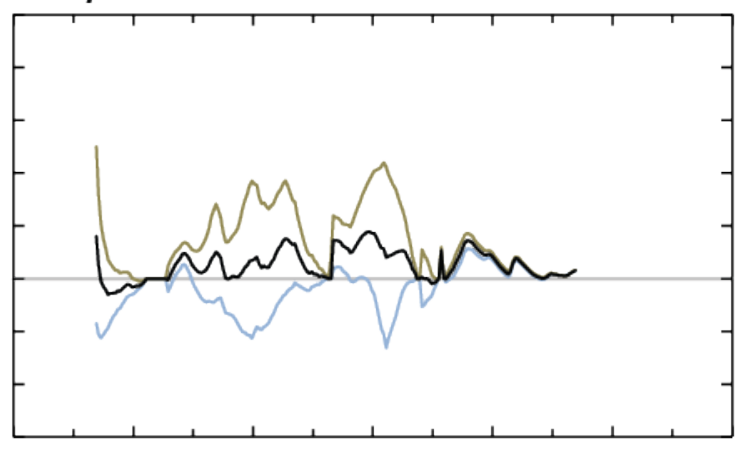

D. 50-year future condition

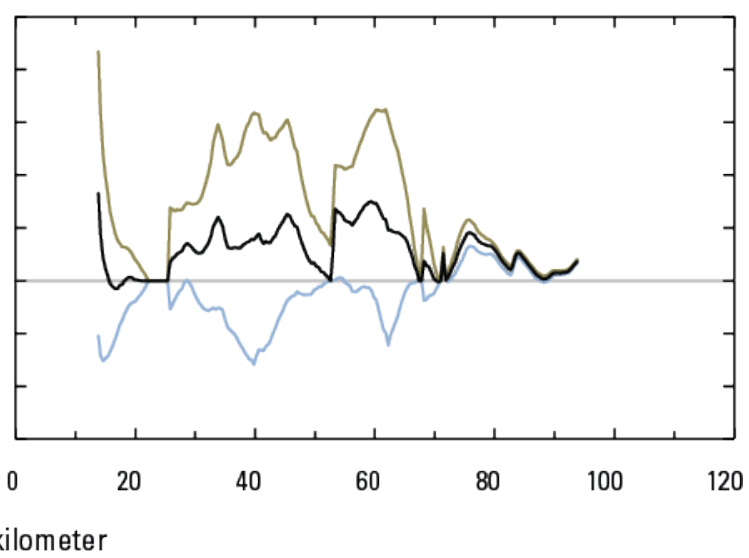

Figure 49. Graph showing potential future bed-elevation change for the White River after 25 years for $(A)$ a baseline condition and (B) a future condition; and after 50 years for (C) a baseline condition and (D) a future condition. 

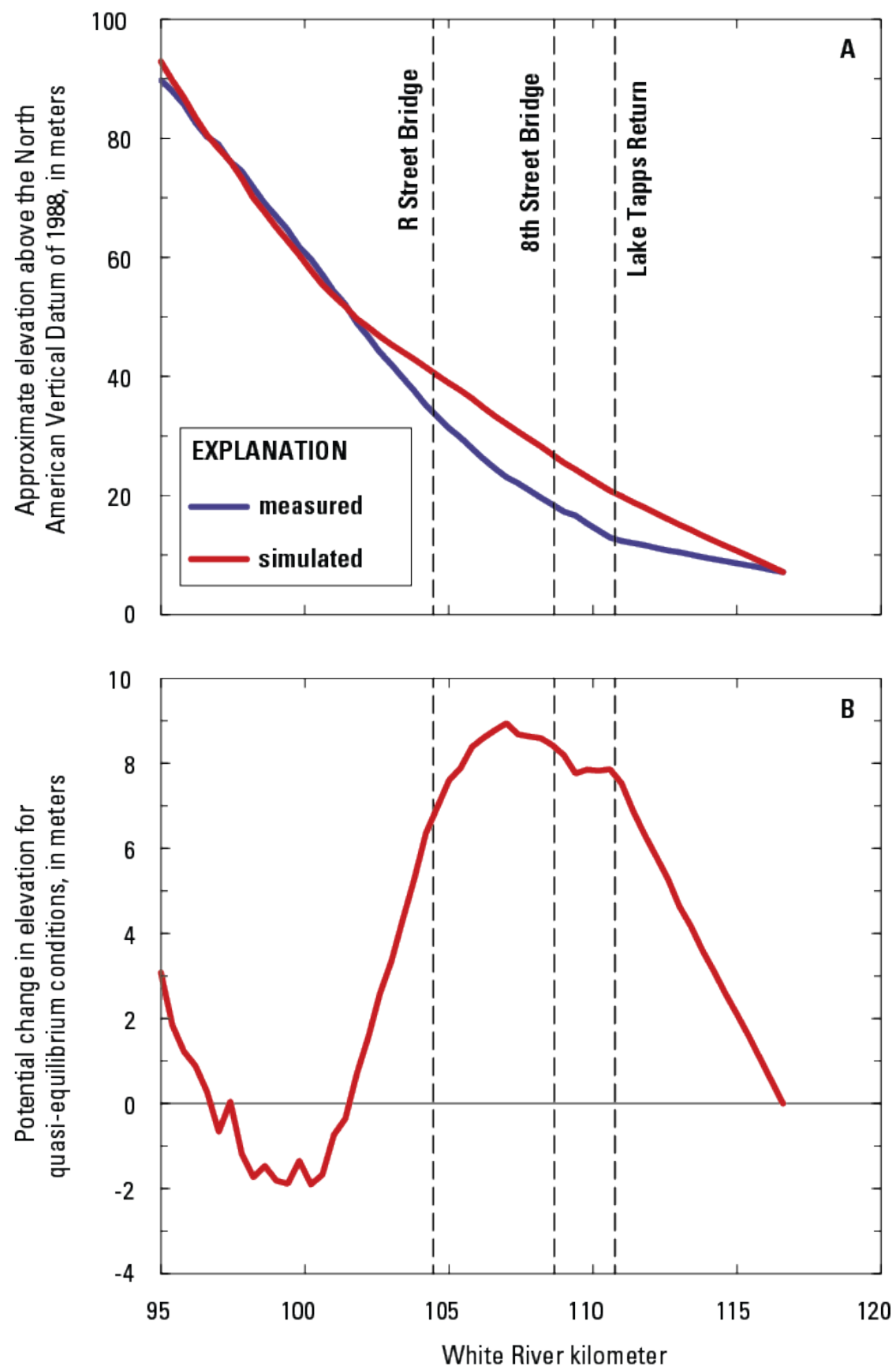

Figure 50. Graph showing lower White River, Washington, (A) approximate bed elevations from measurements (raw model input) and from steady state simulations (after model conditioning) and (B) change in elevation after the model-conditioning process with quasi-equilibrium conditions. 


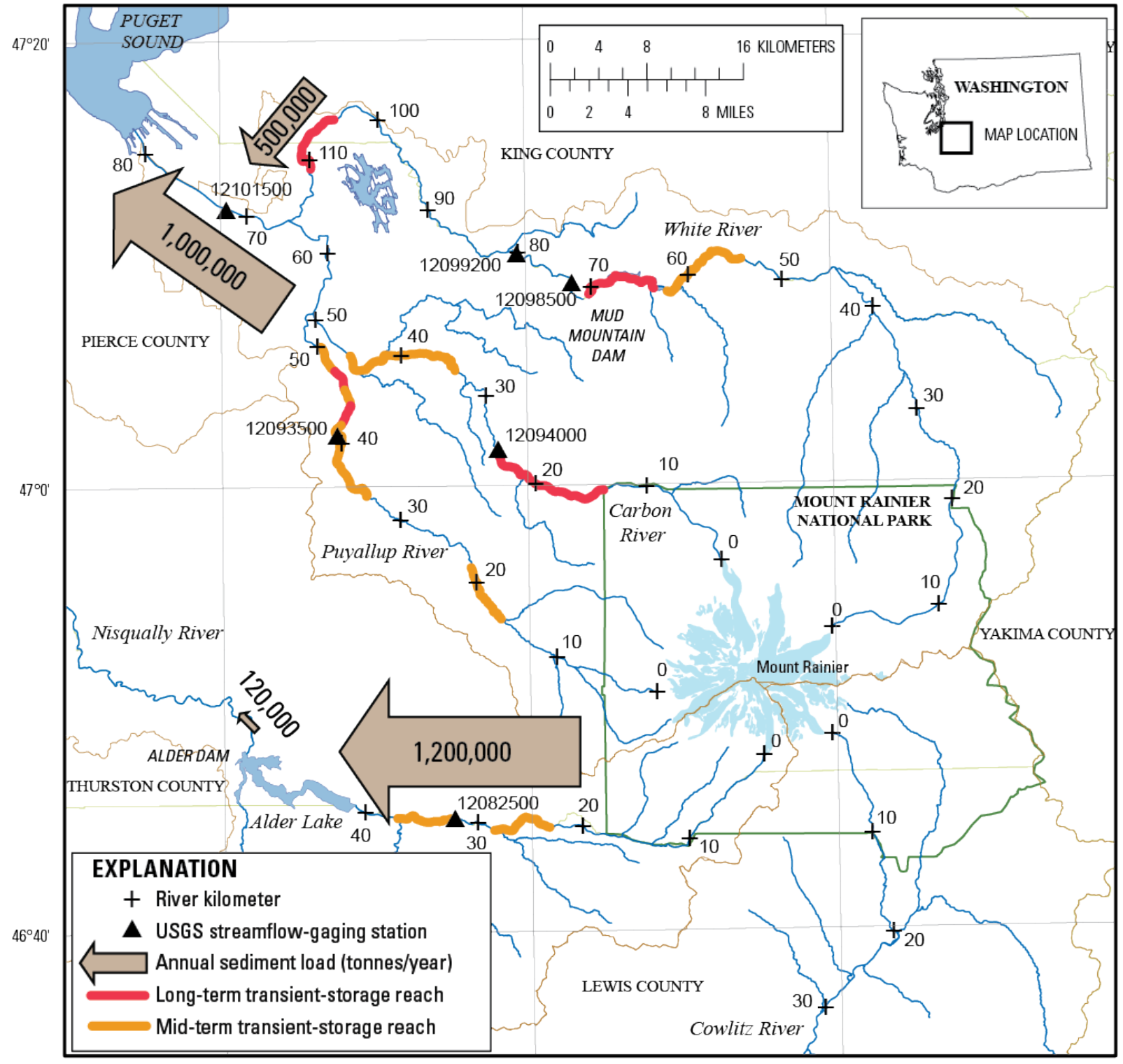

Figure 51. Map of Mount Rainier, Washington, showing where potential sediment-management actions would be most effective based on geomorphic conditions that suggest sediment accumulates naturally, including both long- and mid-term transient-storage reaches. Also shown are best estimates for long-term sediment-load values for rivers in the study. 
Table 1. U.S. Geological Survey streamflow-gaging stations in the State of Washington used for hydrologic and geomorphic analysis in this study.

[ $\mathrm{km}^{2}$, square kilometer]

\begin{tabular}{|c|c|c|c|}
\hline $\begin{array}{l}\text { Station } \\
\text { number }\end{array}$ & Station name & $\begin{array}{c}\text { Drainage } \\
\text { area }\left(\mathrm{km}^{2}\right)\end{array}$ & Available record \\
\hline 12082500 & Nisqually River near National & 344 & $6 / 1 / 1942$ to present \\
\hline 12083000 & Mineral Creek near Mineral & 195 & $6 / 1 / 1942$ to present \\
\hline 12093500 & Puyallup River near Orting & 445 & $10 / 1 / 1931$ to present \\
\hline 12094000 & Carbon River near Fairfax & 204 & $\begin{array}{l}12 / 1 / 1910 \text { to } 6 / 30 / 1912 \\
4 / 1 / 1929 \text { to } 5 / 31 / 1978 \\
10 / 1 / 1991 \text { to } \text { present }\end{array}$ \\
\hline 12094300 & Carbon River near Orting & 250 & $11 / 17 / 1970$ to $2 / 24 / 1986$ \\
\hline 12097850 & $\begin{array}{l}\text { White River below Clearwater River near } \\
\text { Buckley }\end{array}$ & 971 & $\begin{array}{l}6 / 1 / 1974 \text { to } 10 / 13 / 1976 \\
3 / 18 / 1982 \text { to } 2 / 7 / 1996 \\
10 / 1 / 2008 \text { to } \text { present }\end{array}$ \\
\hline 12098500 & White River near Buckley & 1,040 & $\begin{array}{l}10 / 1 / 1928 \text { to } 9 / 30 / 1933 \\
10 / 1 / 1938 \text { to } 9 / 30 / 2003\end{array}$ \\
\hline 12099200 & White River above Boise Creek at Buckley & 1,060 & $7 / 18 / 2003$ to present \\
\hline 12100490 & White River at R Street near Auburn & 1,230 & $5 / 29 / 2009$ to present \\
\hline 12100496 & White River near Auburn & 1,230 & $8 / 20 / 1987$ to $9 / 30 / 2009$ \\
\hline 12101500 & Puyallup River at Puyallup & 2,460 & $5 / 1 / 1914$ to present \\
\hline 14226500 & Cowlitz River at Packwood & 743 & $\begin{array}{l}\text { 7/1/1911 to } 9 / 30 / 1919 \\
10 / 1 / 1929 \text { to present }\end{array}$ \\
\hline
\end{tabular}


Table 2. Twenty largest peak-flow events at the U.S. Geological Survey streamflow-gaging station Nisqually River near National (12082500) between 1989 and 2009 and the resulting change in stage, for median flow, at the gage after to peak-flow event.

[PDT, Pacific Daylight Time; $\mathrm{m}^{3}$, square meter; s, second; m, meter]

\begin{tabular}{lcccc}
\hline Peak-flow date & $\begin{array}{c}\text { Peak-flow time } \\
(\text { PDT })\end{array}$ & $\begin{array}{c}\text { Maximum } \\
\text { discharge }\left(\mathbf{m}^{3} / \mathbf{s}\right)\end{array}$ & $\begin{array}{c}\text { Daily average } \\
\text { discharge }\left(\mathbf{m}^{3} / \mathbf{s}\right)\end{array}$ & $\begin{array}{c}\text { Change in stage } \\
(\mathbf{m})\end{array}$ \\
\hline $12 / 4 / 1989$ & $16: 30$ & 249 & 165 & -0.43 \\
$1 / 9 / 1990$ & $15: 45$ & 411 & 279 & -0.43 \\
$11 / 24 / 1990$ & $21: 30$ & 311 & 223 & -0.03 \\
$12 / 20 / 1994$ & $11: 30$ & 192 & 166 & -0.01 \\
$2 / 1 / 1995$ & $0: 45$ & 194 & 138 & 0.01 \\
$11 / 8 / 1995$ & $17: 15$ & 212 & 135 & -0.09 \\
$11 / 29 / 1995$ & $19: 30$ & 467 & 354 & -0.09 \\
$2 / 8 / 1996$ & $14: 00$ & 600 & 445 & -0.28 \\
$1 / 1 / 1997$ & $3: 45$ & 232 & 183 & -0.13 \\
$3 / 19 / 1997$ & $11: 45$ & 272 & 227 & 0.08 \\
$11 / 26 / 1998$ & $4: 30$ & 167 & 131 & 0.03 \\
$11 / 25 / 1999$ & $18: 15$ & 248 & 164 & 0.17 \\
$1 / 8 / 2002$ & $0: 30$ & 244 & 167 & -0.15 \\
$1 / 31 / 2003$ & $9: 30$ & 306 & 244 & -0.13 \\
$1 / 18 / 2005$ & $9: 00$ & 230 & 157 & 0.15 \\
$12 / 24 / 2005$ & $4: 30$ & 174 & 166 & 0.20 \\
$1 / 10 / 2006$ & $9: 00$ & 199 & 174 & 0.20 \\
$11 / 6 / 2006$ & $17: 20$ & 617 & 425 & 0.68 \\
$3 / 25 / 2007$ & $1: 30$ & 189 & 132 & -0.07 \\
$1 / 8 / 2009$ & $4: 45$ & 374 & 242 & -0.34 \\
\hline
\end{tabular}


Table 3. Sample of 81 meteorological, hydrologic, and atmospheric parameters collected and correlated to the change in stage for the 20 largest peak-flow events measured at the Nisqually River gage.

[bold indicated coefficient of determination greater than 0.20 ]

\begin{tabular}{|c|c|c|c|c|}
\hline Variable & Source & $\begin{array}{l}\text { Correlation } \\
\text { coefficient }\end{array}$ & $\begin{array}{c}\text { Coefficient of } \\
\text { determination }\left(R^{2}\right)\end{array}$ & $\begin{array}{l}\text { Available data (out } \\
\text { of } 20 \text { peak events) }\end{array}$ \\
\hline Minimum temperature (day before peak) & SNOTEL $^{1}$ & 0.16 & 0.03 & 20 \\
\hline Minimum temperature (day of peak) & SNOTEL $^{1}$ & 0.24 & 0.06 & 20 \\
\hline Minimum temperature (day after peak) & SNOTEL $^{1}$ & 0.75 & 0.56 & 20 \\
\hline Maximum temperature (day before peak) & SNOTEL $^{1}$ & -0.12 & 0.02 & 20 \\
\hline Maximum temperature (day of peak) & SNOTEL $^{1}$ & 0.32 & 0.11 & 20 \\
\hline Maximum temperature (day after peak) & SNOTEL $^{1}$ & 0.50 & 0.25 & 20 \\
\hline Average temperature (day before peak) & SNOTEL $^{1}$ & 0.04 & 0.00 & 20 \\
\hline Average temperature (day of peak) & SNOTEL $^{1}$ & 0.26 & 0.07 & 20 \\
\hline Average temperature (day after peak) & SNOTEL $^{1}$ & 0.60 & 0.36 & 20 \\
\hline Snow-water equivalent (day before peak) & SNOTEL $^{1}$ & -0.12 & 0.01 & 20 \\
\hline $\begin{array}{l}\text { Cumulative precipitation (day before } \\
\text { peak) }\end{array}$ & SNOTEL $^{1}$ & -0.26 & 0.07 & 20 \\
\hline $\begin{array}{l}\text { Antecedent moisture conditions (total } \\
\text { rainfall } 15 \text { days before peak) }\end{array}$ & Paradise $^{2}$ & 0.06 & 0.00 & 17 \\
\hline Total Precipitation (3 day) & Longmire $^{3}$ & -0.23 & 0.05 & 20 \\
\hline Total Precipitation (1 day) & Longmire $^{3}$ & 0.05 & 0.00 & 20 \\
\hline $\begin{array}{l}\text { Peak rainfall intensity (in } 48 \text { hours before } \\
\text { peak) }\end{array}$ & Longmire $^{3}$ & 0.04 & 0.00 & 15 \\
\hline Freezing elevation ( 12 hours before peak) & Sounding ${ }^{4}$ & 0.34 & 0.11 & 19 \\
\hline Freezing elevation ( 24 hours before peak) & Sounding $^{4}$ & 0.20 & 0.04 & 19 \\
\hline $\begin{array}{l}\text { Pressure at surface elevation ( } 12 \text { hours } \\
\text { before peak) }\end{array}$ & Sounding $^{4}$ & 0.31 & 0.09 & 19 \\
\hline $\begin{array}{l}\text { Dew point at } 3,000 \text { meters ( } 12 \mathrm{hrs} \text { before } \\
\text { peak) }\end{array}$ & Sounding $^{4}$ & -0.10 & 0.01 & 19 \\
\hline Wind direction at 3,000 meters & Sounding $^{4}$ & 0.42 & 0.18 & 18 \\
\hline Wind speed at 3,000 meters & Sounding $^{4}$ & 0.39 & 0.15 & 18 \\
\hline Showalter index & Sounding $^{4}$ & -0.21 & 0.04 & 18 \\
\hline Lifted index & Sounding $^{4}$ & 0.20 & 0.04 & 18 \\
\hline SWEAT index & Sounding $^{4}$ & 0.54 & 0.29 & 16 \\
\hline Precipitable water for entire sounding & Sounding ${ }^{4}$ & 0.36 & 0.13 & 18 \\
\hline
\end{tabular}

${ }^{1}$ Natural Resources Conservation Service (2011)

${ }^{2}$ National Climatic Data Center weather station at Paradise, Washington

${ }^{3}$ National Climatic Data Center weather station at Longmire, Washington

${ }^{4}$ National Oceanic and Atmospheric Administration atmospheric sounding data from Quillayute, Washington 
Table 4. Published sediment-load estimates for rivers in the Mount Rainier National Park, Washington, watershed and for the Pacific Northwest.

$\underline{\left.\mathrm{km}^{2} \text {, square kilometer; yr, year }\right]}$

\begin{tabular}{|c|c|c|c|}
\hline River & $\begin{array}{c}\text { Total annual sediment load'1 } \\
\text { (tonnes/yr) }\end{array}$ & $\begin{array}{c}\text { Drainage area } \\
\left(\mathrm{km}^{2}\right)\end{array}$ & $\begin{array}{c}\text { Yield } \\
\text { ((tonnes/km²)/yr) }\end{array}$ \\
\hline \multicolumn{4}{|c|}{ White River basin } \\
\hline Huckleberry Creek ${ }^{2}$ & 119,234 & 98 & 1,200 \\
\hline West Fork White River ${ }^{2}$ & 332,401 & 171 & 1,900 \\
\hline Greenwater River ${ }^{3,4}$ & 120,000 & 197 & 610 \\
\hline Greenwater River $^{2}$ & 60,232 & 197 & 310 \\
\hline White River melt from Emmons Glacier ${ }^{5,6}$ & 208,000 & 18 & 12,000 \\
\hline White River upstream of Greenwater ${ }^{2}$ & 561,683 & 290 & 1,900 \\
\hline White River above Mud Mountain Dam ${ }^{7,8}$ & 450,000 & 970 & 460 \\
\hline White River near Auburn $^{9}$ & $1,300,000$ & 1,184 & 1,100 \\
\hline \multicolumn{4}{|c|}{ Puyallup River basin } \\
\hline Puyallup River at Puyallup ${ }^{10}$ & 526,000 & 2,564 & 210 \\
\hline Puyallup River at Puyallup ${ }^{11}$ & $1,250,000$ & 2,564 & 490 \\
\hline Puyallup River at Puyallup ${ }^{12}$ & 890,000 & 2,564 & 347 \\
\hline \multicolumn{4}{|c|}{ Nisqually River basin } \\
\hline Tahoma Creek $^{13}$ & 500,000 & 38 & 14,000 \\
\hline Nisqually River near National ${ }^{14}$ & $300,000^{16}$ & 344 & 870 \\
\hline Mineral Creek near Mineral ${ }^{14}$ & $14,000^{16}$ & 195 & 70 \\
\hline Nisqually River at Alder Lake ${ }^{14}$ & $902,000^{16}$ & 623 & 1,400 \\
\hline Nisqually River at La Grande ${ }^{14}$ & $42,000^{16}$ & 756 & 55 \\
\hline Mashel River near La Grande ${ }^{14}$ & $15,000^{16}$ & 209 & 69 \\
\hline $\begin{array}{l}\text { Ohop Creek near Eatonville }{ }^{14} \\
\text { Nisqually River above Powell Creek, near }\end{array}$ & $2,200^{16}$ & 89 & 24 \\
\hline McKenna $^{14}$ & $91,000^{16}$ & 1,116 & 81 \\
\hline Tanwax Creek near McKenna ${ }^{14}$ & $480^{16}$ & 69 & 7 \\
\hline Muck Creek at mouth, near Roy ${ }^{14}$ & $1,500^{16}$ & 238 & 6 \\
\hline Nisqually River near Nisqually ${ }^{14}$ & $95,000^{16}$ & 1,844 & 52 \\
\hline \multicolumn{4}{|c|}{ British Columbia, Canada } \\
\hline Fraser River ${ }^{15}$ & $20,000,000$ & 230,000 & 87 \\
\hline Homathko River ${ }^{15}$ & $4,300,000$ & 5,700 & 750 \\
\hline Klinaklini River ${ }^{15}$ & $5,000,000$ & 6,500 & 770 \\
\hline Skeena River ${ }^{15}$ & $11,000,000$ & 55,000 & 200 \\
\hline Squamish River ${ }^{15}$ & $1,800,000$ & 3,300 & 550 \\
\hline \multicolumn{4}{|c|}{ Washington } \\
\hline Deschutes River near La Grande ${ }^{14}$ & $20,000^{16}$ & 143 & 150 \\
\hline Chehalis River ${ }^{15}$ & 120,000 & 3,300 & 36 \\
\hline Columbia River $^{15}$ & $9,700,000$ & 670,000 & 14 \\
\hline Hoh River ${ }^{15}$ & 720,000 & 650 & 1,100 \\
\hline \multicolumn{4}{|c|}{ Oregon } \\
\hline
\end{tabular}




\begin{tabular}{|c|c|c|c|}
\hline River & $\begin{array}{l}\text { Total annual sediment load } 1 \\
\text { (tonnes/yr) }\end{array}$ & $\begin{array}{c}\text { Drainage area } \\
\left(\mathrm{km}^{2}\right)\end{array}$ & $\begin{array}{c}\text { Yield } \\
\text { ((tonnes/km²)/yr) }\end{array}$ \\
\hline Nehalem River ${ }^{15}$ & 220,000 & 2,200 & 100 \\
\hline Alsea River ${ }^{15}$ & 160,000 & 860 & 190 \\
\hline Tillamook River ${ }^{15}$ & 80,000 & 610 & 130 \\
\hline Coos River ${ }^{15}$ & 190,000 & 1,600 & 120 \\
\hline Coquille River ${ }^{15}$ & 290,000 & 2,700 & 110 \\
\hline Sixes River ${ }^{15}$ & 390,000 & 300 & 1,300 \\
\hline Rogue River ${ }^{15}$ & $2,300,000$ & 14,000 & 160 \\
\hline Siuslaw River ${ }^{15}$ & 94,000 & 1,500 & 63 \\
\hline Umpqua River ${ }^{15}$ & $1,400,000$ & 12,000 & 120 \\
\hline Siletz River ${ }^{15}$ & 60,000 & 520 & 120 \\
\hline Smith River ${ }^{15}$ & 300,000 & 1,600 & 190 \\
\hline
\end{tabular}

${ }^{1}$ Assumes bulk density of 1.65 tonnes $/ \mathrm{m}^{3}$

${ }^{2}$ Ketcheson and others (2003)

${ }^{3}$ Laurie (2002)

${ }^{4}$ Abbe and others (2007)

${ }^{5}$ Fahnestock (1963)

${ }^{6}$ Mills (1976)

${ }^{7}$ Dunne (1986)

${ }^{8}$ Nelson (1978)

${ }^{9}$ Herrera Environmental Consultants (2010)

${ }^{10}$ Downing (1983)

${ }^{11}$ Wise and others (2007)

${ }^{12}$ Czuba and others (2011)

${ }^{13}$ Walder and Driedger (1994)

${ }^{14}$ Nelson (1974)

${ }^{15}$ Milliman and Farnsworth (2011)

${ }^{16}$ Bedload not included 
Table 5. Summary of active-channel width measured in 1965, 1994, and 2009 and the change in width between dates, for rivers draining Mount Rainier, Washington.

[km, kilometer; m, meter]

\begin{tabular}{|c|c|c|c|c|c|c|c|}
\hline \multirow{2}{*}{ Tributary or river segment } & \multirow{2}{*}{$\begin{array}{l}\text { Draining } \\
\text { glacier }^{1}\end{array}$} & \multirow{2}{*}{$\begin{array}{l}\text { Total length } \\
\text { in } 2009 \\
(\mathrm{~km})\end{array}$} & \multicolumn{3}{|c|}{$\begin{array}{l}\text { Mean active-channel } \\
\text { width }(\mathrm{m})\end{array}$} & \multicolumn{2}{|c|}{$\begin{array}{l}\text { Difference in mean } \\
\text { active-channel } \\
\text { width }(\mathrm{m})\end{array}$} \\
\hline & & & 1965 & 1994 & 2009 & $\begin{array}{l}\text { from } \\
1965 \text { to } \\
1994\end{array}$ & $\begin{array}{l}\text { from } \\
1994 \text { to } \\
2009\end{array}$ \\
\hline \multicolumn{8}{|c|}{ Carbon River } \\
\hline $\begin{array}{l}\text { Carbon River upstream of } \\
\text { national park boundary }\end{array}$ & Carbon & 13.4 & 156 & 163 & 208 & 6 & 45 \\
\hline $\begin{array}{l}\text { Carbon River from national park } \\
\text { boundary to canyon }\end{array}$ & Carbon & 12.2 & 123 & 122 & 160 & -0.8 & 38 \\
\hline \multicolumn{8}{|c|}{ White River } \\
\hline $\begin{array}{l}\text { West Fork White River upstream } \\
\text { of national park boundary }\end{array}$ & Winthrop & 9.7 & 64 & 70 & 105 & 6 & 35 \\
\hline $\begin{array}{l}\text { West Fork White River } \\
\text { downstream of park boundary }\end{array}$ & Winthrop & 17.4 & 95 & 104 & 126 & 9 & 22 \\
\hline Inter Fork White River & Inter & 4.9 & 22 & 16 & 32 & -6 & 16 \\
\hline Fryingpan Creek & Fryingpan & 5.6 & 25 & 29 & 31 & 5 & 2 \\
\hline Wright Creek & Sarvant & 1.9 & 22 & 5 & 8 & -17 & 3 \\
\hline $\begin{array}{l}\text { White River upstream of national } \\
\text { park boundary }\end{array}$ & Emmons & 21.4 & 106 & 101 & 137 & -5 & 36 \\
\hline $\begin{array}{l}\text { White River downstream of park } \\
\text { boundary to West Fork White } \\
\text { River }\end{array}$ & Multiple & 18.2 & 67 & 60 & 85 & -8 & 25 \\
\hline $\begin{array}{l}\text { White River downstream of West } \\
\text { Fork White River to Mud } \\
\text { Mountain Dam }\end{array}$ & Multiple & 24.0 & 76 & 68 & 94 & -8 & 27 \\
\hline \multicolumn{8}{|c|}{ Cowlitz River } \\
\hline Ohanapecosh River & Ohanapecosh & 27.2 & - & 21 & 23 & - & 2 \\
\hline Williwakas Creek & None & 4.1 & 17 & 25 & 26 & 8 & 0.5 \\
\hline
\end{tabular}




\begin{tabular}{|c|c|c|c|c|c|c|c|}
\hline \multirow{2}{*}{ Tributary or river segment } & \multirow{2}{*}{$\begin{array}{l}\text { Draining } \\
\text { glacier }^{1}\end{array}$} & \multirow{2}{*}{$\begin{array}{l}\text { Total length } \\
\text { in } 2009 \\
(\mathrm{~km})\end{array}$} & \multicolumn{3}{|c|}{$\begin{array}{l}\text { Mean active-channel } \\
\text { width }(\mathrm{m})\end{array}$} & \multicolumn{2}{|c|}{$\begin{array}{l}\text { Difference in mean } \\
\text { active-channel } \\
\text { width }(\mathrm{m})\end{array}$} \\
\hline & & & 1965 & 1994 & 2009 & $\begin{array}{l}\text { from } \\
1965 \text { to } \\
1994\end{array}$ & $\begin{array}{l}\text { from } \\
1994 \text { to } \\
2009\end{array}$ \\
\hline Stevens Creek & Stevens & 9.0 & 33 & 29 & 36 & -4 & 7 \\
\hline Muddy Fork Cowlitz River & $\begin{array}{l}\text { Ingraham- } \\
\text { Cowlitz }\end{array}$ & 19.7 & 49 & 37 & 50 & -12 & 13 \\
\hline $\begin{array}{l}\text { Cowlitz River from Ohanapecosh } \\
\text { to Riffe Lake }\end{array}$ & Multiple & 62.3 & - & - & 158 & - & - \\
\hline \multicolumn{8}{|c|}{ Nisqually River } \\
\hline Van Trump Creek & Van Trump & 3.9 & - & 19 & 27 & - & 8 \\
\hline Kautz Creek & Kautz & 10.5 & 116 & 63 & 102 & -53 & 38 \\
\hline & $\begin{array}{l}\text { Tahoma and } \\
\text { South }\end{array}$ & & & & & & \\
\hline Tahoma Creek & Tahoma & 10.7 & 61 & 115 & 143 & 54 & 28 \\
\hline $\begin{array}{l}\text { Nisqually River upstream of } \\
\text { national park boundary }\end{array}$ & $\begin{array}{l}\text { Nisqually- } \\
\text { Wilson }\end{array}$ & 17.7 & 106 & 92 & 127 & -14 & 35 \\
\hline $\begin{array}{l}\text { Nisqually River downstream of } \\
\text { park boundary to Alder Lake }\end{array}$ & Multiple & 25.4 & 195 & 190 & 231 & -5 & 40 \\
\hline \multicolumn{8}{|c|}{ Puyallup River } \\
\hline North Mowich River & $\begin{array}{l}\text { North } \\
\text { Mowich }\end{array}$ & 5.0 & 20 & 11 & 21 & -9 & 10 \\
\hline Mowich River & $\begin{array}{l}\text { South } \\
\text { Mowich }\end{array}$ & 17.5 & 77 & 77 & 104 & 0.4 & 27 \\
\hline South Fork Puyallup River & Tahoma & 12.0 & 36 & 34 & 45 & -2 & 11 \\
\hline $\begin{array}{l}\text { Puyallup River upstream of South } \\
\text { Fork Puyallup River }\end{array}$ & Puyallup & 8.1 & 25 & 19 & 47 & -6 & 28 \\
\hline $\begin{array}{l}\text { Puyallup River downstream of } \\
\text { South Fork Puyallup River to } \\
\text { Mowich River }\end{array}$ & Multiple & 8.0 & 44 & 40 & 64 & -4 & 24 \\
\hline $\begin{array}{l}\text { Puyallup River downstream of } \\
\text { Mowich River to canyon }\end{array}$ & Multiple & 11.4 & 46 & 56 & 77 & 10 & 20 \\
\hline
\end{tabular}


Table 6. Estimated sediment load contribution to river main stems due to increases in active-channel width, for rivers draining Mount Rainier, Washington, 1965-2009.

$\left[\mathrm{km}\right.$, kilometer; $\mathrm{m}^{3}$, square meter; yr, year; $\mathrm{m}$, meter; CRKM, Carbon River kilometer; NRKM, Nisqually River kilometer; PRKM, Puyallup River kilometer; WRKM, White River kilometer]

\begin{tabular}{lllllc}
\multicolumn{1}{c}{ River } & Reach analyzed & $\begin{array}{c}\text { Length of } \\
\text { river } \\
\text { analyzed } \\
\mathbf{( k m )}\end{array}$ & $\begin{array}{c}\text { Annual volume of } \\
\text { sediment mobilized } \\
\text { from flood plain, in } \\
\mathbf{m} 3 / \mathbf{y r}\end{array}$ & $\begin{array}{c}\text { Annual mass of } \\
\text { sediment mobilized } \\
\text { from flood plain, in } \\
\text { tonnes/yr }\end{array}$ & $\begin{array}{c}\text { Annual volume of } \\
\text { sediment } \\
\text { mobilized from } \\
\text { flood plain per unit } \\
\text { length, in } \mathbf{m}^{3} / \mathbf{y r} / \mathbf{m}\end{array}$ \\
\hline Carbon & CRKM 13.7-23.9 & 10.2 & $13,000-27,000$ & $20,000-48,000$ & $1.3-2.6$ \\
Nisqually & NRKM 17.8-40.2 & 22.3 & $45,000-170,000$ & $67,000-300,000$ & $2.0-7.5$ \\
Puyallup & PRKM 5.4-20.8 & 14.5 & $10,000-78,000$ & $14,000-140,000$ & $0.7-5.4$ \\
White & WRKM 21.2-55.7 & 34.4 & $15,000-100,000$ & $23,000-180,000$ & $0.4-2.9$ \\
\hline
\end{tabular}


Table 7. Summary of sediment-production potential for Cascade Range subcatchments outside Mount Rainier National Park, Washington.

[MORA, Mount Rainier National Park; $\mathrm{km}^{2}$, square kilometer; yr, year]

\begin{tabular}{|c|c|c|c|}
\hline Subcatchment & $\begin{array}{l}\text { Total sediment } \\
\text { production } \\
\text { (tonnes/yr) }\end{array}$ & $\begin{array}{l}\text { Uncertainty in } \\
\text { total sediment } \\
\text { production } \\
\text { estimate } \\
\text { (tonnes/yr) }\end{array}$ & $\begin{array}{c}\text { Yield } \\
\text { ((tonnes/km²)/yr) }\end{array}$ \\
\hline
\end{tabular}

\begin{tabular}{|c|c|c|c|c|}
\hline \multicolumn{5}{|c|}{ Upper Nisqually River Basin (total area outside MORA $=605 \mathrm{~km}^{2}$ ) } \\
\hline Big Creek & 12,000 & \pm & 8,000 & 120 \\
\hline Kautz Creek & - & & - & - \\
\hline Little Nisqually River & 8,500 & \pm & 5,900 & 130 \\
\hline Mineral Creek & 13,000 & \pm & 8,400 & 68 \\
\hline Nisqually River in MORA & - & & - & - \\
\hline Nisqually River, MORA to Alder Lake & 16,000 & \pm & 11,000 & 70 \\
\hline Tahoma Creek & - & & - & - \\
\hline Total & 50,000 & \pm & 33,000 & 84 \\
\hline \multicolumn{5}{|c|}{ Puyallup River Basin (total area outside MORA = 352 km²) } \\
\hline Deer Creek & 7,900 & \pm & 5,600 & 270 \\
\hline Mowich River & 9,000 & \pm & 6,400 & 250 \\
\hline North Puyallup River & 3,000 & \pm & 2,200 & 820 \\
\hline Middle Puyallup River & 16,000 & \pm & 10,000 & 61 \\
\hline South Puyallup River & 6,400 & \pm & 4,600 & 380 \\
\hline Total & 42,000 & \pm & 29,000 & 120 \\
\hline \multicolumn{5}{|c|}{ Carbon River Basin (total area outside MORA $=484 \mathrm{~km}^{2}$ ) } \\
\hline Upper Carbon River & - & & - & - \\
\hline Lower Carbon River & 14,000 & \pm & 9,600 & 110 \\
\hline Chenuis Creek & 2,000 & \pm & 1,400 & 160 \\
\hline Evans Creek & 3,900 & \pm & 2,800 & 200 \\
\hline Lily Creek & 1,700 & \pm & 1,200 & 150 \\
\hline South Prairie Creek & 15,000 & \pm & 9,300 & 63 \\
\hline Voight Creek & 5,300 & \pm & 3,400 & 63 \\
\hline Total & 42,000 & \pm & 28,000 & 86 \\
\hline \multicolumn{5}{|c|}{ White River Basin (total area outside MORA $=943 \mathrm{~km}^{2}$ ) } \\
\hline Boise Creek & 3,200 & \pm & 1,800 & 77 \\
\hline Canyon Creek & 2,200 & \pm & 1,300 & 130 \\
\hline Clearwater River & 18,000 & \pm & 11,000 & 180 \\
\hline Greenwater River & 29,000 & \pm & 21,000 & 150 \\
\hline Huckleberry Creek & 9,900 & \pm & 7,200 & 240 \\
\hline West Fork White River & 17,000 & \pm & 12,000 & 180 \\
\hline
\end{tabular}




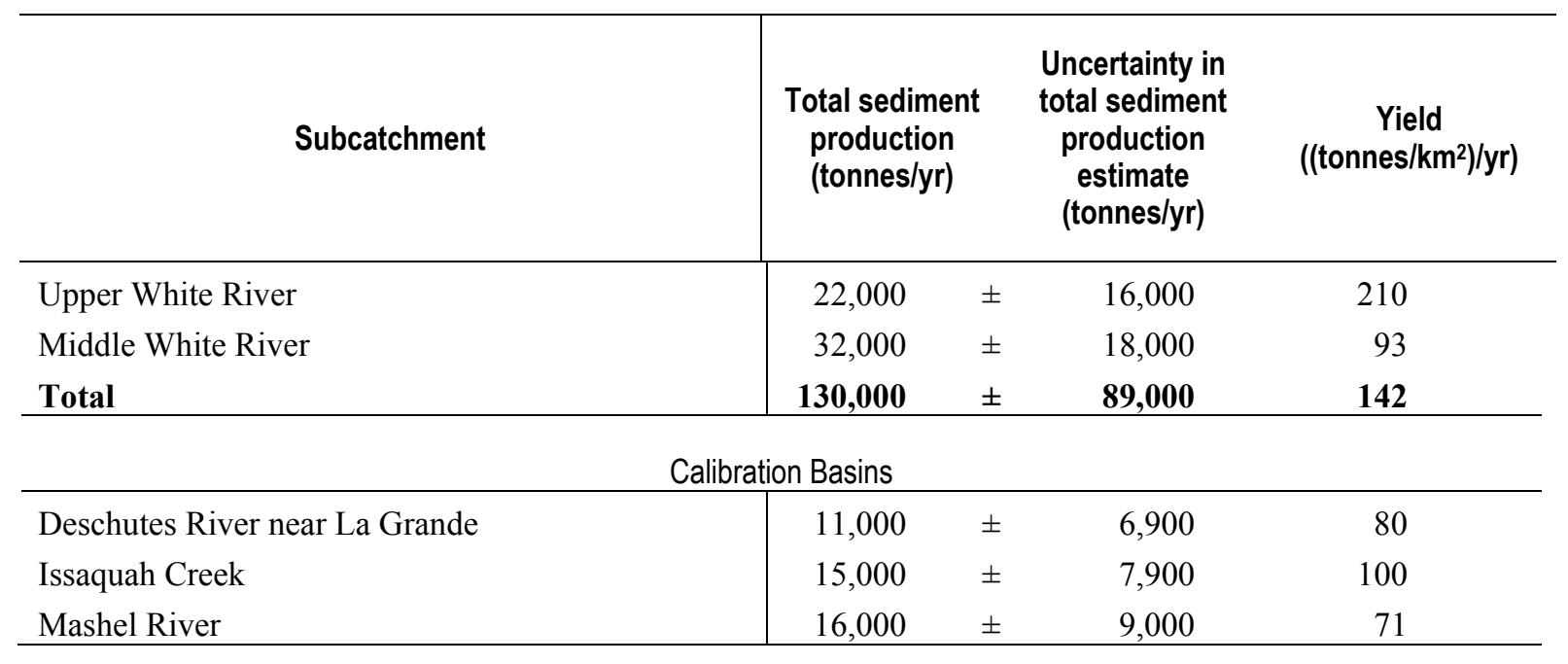


Table 8. Sediment load calculations and measurements completed as part of this study, for rivers draining Mount Rainier, Washington.

$\left[\mathrm{km}^{2}\right.$, square kilometer; yr, year $]$

\begin{tabular}{|c|c|c|c|c|}
\hline Location & $\begin{array}{l}\text { Total annual sediment } \\
\text { discharge (tonnes/yr) }\end{array}$ & $\begin{array}{c}\text { Drainage } \\
\text { area }\left(\mathrm{km}^{2}\right)\end{array}$ & $\begin{array}{c}\text { Yield } \\
\text { ((tonnes/km²)/yr) }\end{array}$ & $\begin{array}{l}\text { Period of sediment-load } \\
\text { estimates }\end{array}$ \\
\hline $\begin{array}{l}\text { Nisqually River } \\
\text { into Adler Lake }\end{array}$ & $1,200,000 \pm 180,000$ & 590 & $2,000 \pm 300$ & $1945-2011$ \\
\hline $\begin{array}{l}\text { Nisqually River } \\
\text { into Adler Lake, } \\
\text { 1956-1985 }\end{array}$ & $860,000 \pm 370,000$ & 590 & $1,500 \pm 630$ & 1956-1985 \\
\hline $\begin{array}{l}\text { Little Nisqually } \\
\text { River in Alder } \\
\text { Lake }\end{array}$ & $7,800 \pm 2,600$ & 67 & $120 \pm 39$ & $1945-2011$ \\
\hline $\begin{array}{l}\text { Nisqually River } \\
\text { downstream of } \\
\text { Alder Dam }\end{array}$ & $120,000 \pm 18,000$ & 590 & $200 \pm 25$ & $1945-2011$ \\
\hline $\begin{array}{l}\text { Puyallup River at } \\
\text { Puyallup }\end{array}$ & $860,000 \pm 300,000^{1.2}$ & 2,450 & $350 \pm 120$ & 1978-1994 \\
\hline $\begin{array}{l}\text { Puyallup River at } \\
\text { Puyallup }\end{array}$ & $1,000,000 \pm 400,000^{3}$ & 2,450 & $400 \pm 160$ & late 20th century-2011 \\
\hline $\begin{array}{l}\text { White River at R } \\
\text { Street near Auburn }\end{array}$ & 420,000 & 1,230 & 340 & April 2010-March 2012 \\
\hline $\begin{array}{l}\text { White River at R } \\
\text { Street near Auburn }\end{array}$ & 590,000 & 1,230 & 480 & water year 2011 \\
\hline $\begin{array}{l}\text { White River at R } \\
\text { Street near Auburn }\end{array}$ & $500,000 \pm 200,000^{3}$ & 1,230 & $400 \pm 160$ & late 20th century-2011 \\
\hline
\end{tabular}


Table 9. Scaling factors and U.S. Geological Survey streamflow-gaging stations used in developing long-term streamflow records for model simulations for the Nisqually, Carbon, Puyallup, and White Rivers, Washington. [USGS Streamflow-gaging stations: 12082500, Nisqually River near National; 12094000, Carbon River near Fairfax; 12093500, Puyallup River near Orting; 12101500, Puyallup River at Puyallup; 12098500, White River near Buckley; 12099200, White River above Boise Creek at Buckley; $\mathrm{m}^{3}$, square meter; s, second]

\begin{tabular}{|c|c|c|c|c|}
\hline $\begin{array}{l}\text { Reach, in } \\
\text { kilometers, for } \\
\text { model nodes } \\
\text { every } 0.4 \\
\text { kilometers }\end{array}$ & Water years & $\begin{array}{l}\text { Gaging station for which flow data were } \\
\text { obtained }\end{array}$ & $\begin{array}{l}\text { Scaling factor (SF) for } \\
\text { applying gaging-station } \\
\text { data to the river reach }\end{array}$ & $\begin{array}{c}\text { 2-year } \\
\text { recurrence- } \\
\text { interval flow, } \\
\mathrm{m}^{3} / \mathrm{s}\end{array}$ \\
\hline \multicolumn{5}{|c|}{ Nisqually River } \\
\hline $14.2-27.8$ & $1946-2011$ & 12082500 & 0.70 & 125 \\
\hline $28.2-37.0$ & $1946-2011$ & 12082500 & 1.00 & 179 \\
\hline $37.4-41.0$ & $1946-2011$ & 12082500 & 1.60 & 286 \\
\hline \multicolumn{5}{|c|}{ Carbon River } \\
\hline $8.2-21.0$ & $1930-2011$ & 12094000 & 0.90 & 98 \\
\hline $21.4-41.0$ & $1930-2011$ & 12094000 & 1.00 & 109 \\
\hline $41.4-43.8$ & $1930-2011$ & 12094000 & 1.50 & 164 \\
\hline $44.2-50.2$ & $1930-2011$ & 12094000 & 1.65 & 180 \\
\hline \multicolumn{5}{|c|}{ Puyallup River } \\
\hline $16.2-53.8$ & $1932-2011$ & 12093500 & 1.00 & 191 \\
\hline $54.2-65.4$ & $1932-2011$ & $12093500(x$ SF 1$)+12094000(x$ SF2 $)$ & 1.00 (SF1), 1.65 (SF2) & 343 \\
\hline $65.8-82.2$ & $1932-2011$ & 12101500 & 1.00 & 667 \\
\hline \multicolumn{5}{|c|}{ White River } \\
\hline $13.4-33.0$ & 1939-2011 & 12094000 & 1.00 & 109 \\
\hline $33.4-39.0$ & 1939-2011 & 12094000 & 1.40 & 153 \\
\hline $39.4-44.6$ & 1939-2011 & 12094000 & 2.05 & 224 \\
\hline $45.0-61.4$ & 1939-2011 & 12094000 & 2.90 & 317 \\
\hline $61.8-70.6$ & 1939-2011 & 12094000 & 3.30 & 361 \\
\hline $71.0-116.6$ & 1939-2003 & 12098500 & 1.00 & 352 \\
\hline $71.0-116.6$ & 2004-2011 & 12099200 & 1.00 & - \\
\hline
\end{tabular}


Table 10. Comparison of simulated sediment load into Alder Lake by the Nisqually River to measured sediment volumes of the delta of the Nisqually River in Alder Lake, Washington, from Czuba and others (2012). $\left[\mathrm{m}^{3}\right.$, cubic meter; yr, year]

\begin{tabular}{lcc}
\hline Time Period & $\begin{array}{c}\text { Measured volume (and estimated } \\
\text { uncertainty) of the Nisqually River delta in } \\
\text { Alder Lake }\left(\mathbf{m}^{3}\right)^{1}\end{array}$ & $\begin{array}{c}\text { Simulated volume } \\
\text { transported into } \\
\text { Alder Lake }\left(\mathbf{m}^{3}\right)\end{array}$ \\
\hline $1946-1956$ & $9,000,000 \pm 2,000,000$ & $7,000,000$ \\
$1946-1985$ & $22,000,000 \pm 5,000,000$ & $27,000,000$ \\
$1946-2011$ & $42,000,000 \pm 4,000,000$ & $45,000,000$ \\
\hline Mean annual rate between water years & & \\
1946 and $2011\left(\mathrm{~m}^{3} / \mathrm{yr}\right)$ & $630,000 \pm 60,000$ & 690,000 \\
\hline
\end{tabular}

${ }^{1}$ Data from Czuba and others, 2012; does not include reservoir deposition downstream of the delta 
Table 11. Simulated bed-material sediment loads for the Nisqually River at State Route 7, Carbon River at State Route 162/Pioneer Way, Puyallup River at Calistoga Street, and White River at R Street, Washington. Streamflow at the White River at R Street is controlled by Mud Mountain Dam.

$\left[\mathrm{m}^{3}\right.$, cubic meter; yr, year; s, second; CRKM, Carbon River kilometer; NRKM, Nisqually River kilometer; PRKM, Puyallup River kilometer; WRKM, White River kilometer]

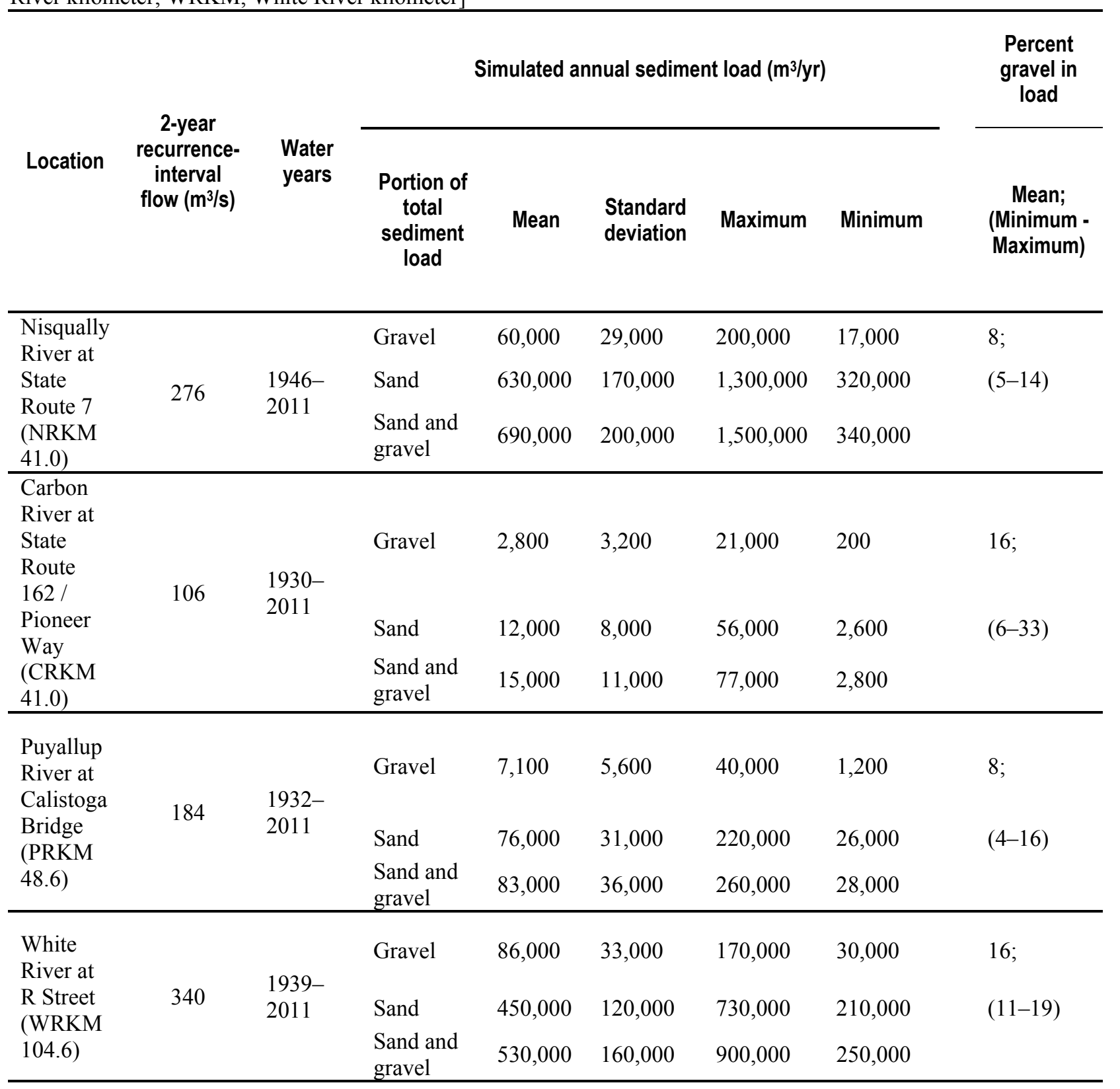




\section{Appendix A. Auxillary Tables}

Table A1. Light Detection and Ranging (LiDAR) data source for river profiles, Washington.

[Source of Lidar data and year is listed in table footnote. DEM, Digital Elevation Model; NASA, National Aeronautics and Space Administration; NED, National Elevation Dataset; PSLC, Puget Sound LiDAR Consortium, accessed September 4, 2012, at http://pugetsoundlidar.ess.washington.edu/; USGS, United States Geological Survey]

\begin{tabular}{|c|c|}
\hline River & LiDAR data source, in footnotes \\
\hline Carbon River & $3,5,9$ \\
\hline Chenuis Creek & 3,10 \\
\hline Evans Creek & 5 \\
\hline Lily Creek & 5,9 \\
\hline South Prairie Creek & 5,9 \\
\hline Voight Creek & 5,9 \\
\hline Wilkeson Creek & 5,9 \\
\hline Cowlitz River & 5,8 \\
\hline Butter Creek & 8,10 \\
\hline Clear Fork Cowlitz River & 8,10 \\
\hline Johnson Creek & 8,10 \\
\hline Lake Creek & 8,10 \\
\hline Ohanapecosh River & 3,8 \\
\hline Silver Creek & 8,10 \\
\hline Skate Creek & 8,10 \\
\hline Nisqually River & 7 \\
\hline Big Creek & 7 \\
\hline Catt Creek & $6,7,10$ \\
\hline Kautz Creek & 3 \\
\hline Mineral Creek & $6,7,10$ \\
\hline North Fork Mineral Creek & 6,7 \\
\hline Tahoma Creek & 3 \\
\hline Puyallup River & $3,5,9$ \\
\hline Deer Creek & 5 \\
\hline Mowich River & 3,5 \\
\hline South Puyallup River & 3,5 \\
\hline White River & $1,3,4,9$ \\
\hline Boise Creek & 1 \\
\hline Canyon Creek & 10 \\
\hline Clearwater River & 10 \\
\hline Greenwater River & 4,10 \\
\hline Huckleberry Creek & $3,4,10$ \\
\hline West Fork White River & $3,4,10$ \\
\hline
\end{tabular}

1 King County; 2003

2 King County; Lower White River; 2009

3 Mount Rainier National Park; 2009 
4 Mount Rainier National Park; Upper White River; 2007

5 NASA/USGS; West Mt. Rainier 2002/2003

6 PSLC; Lewis County; 2003

7 PSLC; Lewis County; 2009

8 PSLC; Lewis County (6-foot geodatabase); 2009

9 PSLC; Puget Sound Lowlands; Pierce County; 2004

10 USGS; NED 1/3 Arc Second (10 meter) DEM 
Table A2. Suspended-sediment concentration measurements at USGS streamflow-gaging station White River at $R$ Street near Auburn (12100490) for water years 2010-2011.

$\left[\mathrm{m}^{3}\right.$, cubic meter; s, second; FNU, formazine nephelometric unit; mg, milligram; L, liter; mm, millimeter; d, day]

\begin{tabular}{|c|c|c|c|c|c|c|c|}
\hline \multirow{2}{*}{ Date / Time } & \multirow{2}{*}{$\begin{array}{l}\text { Streamflow } \\
\left(\mathrm{m}^{3} / \mathrm{s}\right)\end{array}$} & \multirow{2}{*}{$\begin{array}{l}\text { Turbidity } \\
\text { (FNU) }\end{array}$} & \multicolumn{3}{|c|}{$\begin{array}{l}\text { Suspended-sediment concentration } \\
\qquad(\mathrm{mg} / \mathrm{L})\end{array}$} & \multirow{2}{*}{$\begin{array}{l}\text { Percent by } \\
\text { weight finer } \\
\text { than } 0.0625 \mathrm{~mm}\end{array}$} & \multirow{2}{*}{$\begin{array}{l}\text { Suspended- } \\
\text { sediment load } \\
\text { (tonnes/d) }\end{array}$} \\
\hline & & & Fines & Sand & Total & & \\
\hline $6 / 2 / 1011: 45$ & 88 & 15 & 41 & 217 & 258 & 16.0 & 1,970 \\
\hline 6/3/10 11:15 & 132 & 160 & 466 & 694 & 1,160 & 40.2 & 13,200 \\
\hline $8 / 25 / 10 \quad 13: 45$ & 22 & 37 & 37 & 5 & 42 & 87.5 & 79 \\
\hline $12 / 13 / 1014: 30$ & 137 & 285 & 456 & 612 & 1,070 & 42.7 & 12,700 \\
\hline $1 / 18 / 11 \quad 15: 45$ & 202 & 412 & 543 & 645 & 1,190 & 45.7 & 20,800 \\
\hline $1 / 20 / 1115: 15$ & 185 & 240 & 341 & 567 & 908 & 37.6 & 14,500 \\
\hline
\end{tabular}


Table A3. Bedload measurements at USGS streamflow-gaging station White River at R Street near Auburn (12100490) for water years $2010-2011$. [ $\mathrm{m}^{3}$, cubic meter; $\mathrm{s}$, second; $\mathrm{mm}$, millimeter; $\mathrm{d}$, day]

\begin{tabular}{|c|c|c|c|c|c|c|c|c|c|c|c|c|c|c|}
\hline \multirow{2}{*}{ Date / Time } & \multirow{2}{*}{$\begin{array}{l}\text { Streamflow } \\
\left(\mathrm{m}^{3} / \mathrm{s}\right)\end{array}$} & \multirow{2}{*}{$\begin{array}{l}\text { Bedload } \\
\text { (tonnes/d) }\end{array}$} & \multicolumn{12}{|c|}{ Percent by weight finer than indicated size $(\mathrm{mm})$} \\
\hline & & & 0.0625 & 0.125 & 0.25 & 0.5 & 1 & 2 & 4 & 8 & 16 & 32 & 64 & 128 \\
\hline 6/2/10 14:02 & 86 & 149 & 0.0 & 0.2 & 1.5 & 18.4 & 72.0 & 79.6 & 81.0 & 82.6 & 84.4 & 86.6 & 90.8 & 100.0 \\
\hline 6/3/10 12:39 & 124 & 706 & 0.1 & 0.2 & 1.6 & 12.8 & 40.2 & 45.5 & 47.0 & 48.5 & 50.8 & 58.9 & 83.1 & 100.0 \\
\hline $12 / 13 / 1011: 52$ & 137 & 2,286 & 0.0 & 0.1 & 0.4 & 3.3 & 11.3 & 18.1 & 25.5 & 30.2 & 36.8 & 50.8 & 75.7 & 100.0 \\
\hline 1/18/11 13:08 & 202 & 3,659 & 0.0 & 0.0 & 0.1 & 0.9 & 3.4 & 5.3 & 7.8 & 14.1 & 26.5 & 48.2 & 79.5 & 100.0 \\
\hline 1/20/11 12:21 & 185 & 1,165 & 0.0 & 0.1 & 0.2 & 2.4 & 8.9 & 13.1 & 16.8 & 21.6 & 28.3 & 40.6 & 75.9 & 100.0 \\
\hline
\end{tabular}


Publishing support provided by the U.S. Geological Survey

Publishing Network, Tacoma Publishing Service Center

For more information concerning the research in this report, contact the

Director, Washington Water Science Center

U.S. Geological Survey

934 Broadway, Suite 300

Tacoma, Washington 98402

http://wa.water.usgs.gov 


$$
\begin{aligned}
& \text { ख } \\
& \text { क़ }
\end{aligned}
$$

옥

3

疋.

高:

\ู

.

흘

용

产

ग्ञ

음

ㅇ

京 